VILNIAUS GEDIMINO TECHNIKOS UNIVERSITETAS

Raimondas POMARNACKI

\title{
ELEKTRODINAMINIŲ LĖTINIMO [TTAISỤ TYRIMAS TAIKANT LYGIAGREČIĄSIAS KOMPIUTERINES SISTEMAS
}

DAKTARO DISERTACIJA

TECHNOLOGIJOS MOKSLAI,

ELEKTROS IR ELEKTRONIKOS INŽINERIJA (01T)

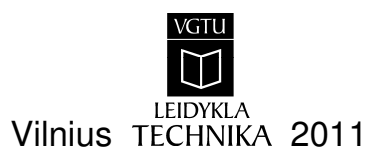


Disertacija rengta 2007-2011 metais Vilniaus Gedimino technikos universitete.

\section{Mokslinis vadovas}

doc. dr. Vytautas URBANAVIČIUS (Vilniaus Gedimino technikos

universitetas, technologijos mokslai, elektros ir elektronikos inžinerija - 01T).

VGTU leidyklos TECHNIKA 1924-M mokslo literatūros knyga http://leidykla.vgtu.lt

ISBN 978-609-457-016-2

(C) VGTU leidykla TECHNIKA, 2011

(C) Raimondas Pomarnacki, 2011

raimondas.pomarnacki@el.vgtu.lt 
VILNIUS GEDIMINAS TECHNICAL UNIVERSITY

Raimondas POMARNACKI

INVESTIGATION OF THE

ELECTRODYNAMIC RETARD DEVICES

USING PARALLEL COMPUTER SYSTEMS

DOCTORAL DISSERTATION

TECHNOLOGICAL SCIENCES,

ELECTRICAL AND ELECTRONIC ENGINEERING (01T)

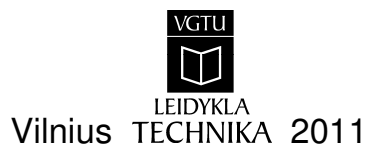


Doctoral dissertation was prepared at Vilnius Gediminas Technical University in 2007-2011.

\section{Scientific Supervisor}

Assoc Prof Dr Vytautas URBANAVIČIUS (Vilnius Gediminas Technical University, Technological Sciences, Electrical and Electronic Engineering 01T). 


\section{Santrauka}

Disertacijoje nagrinejjamos mikrobangų įtaisų analizès ir sintezès problemos, taikant lygiagrečiąsias kompiuterines sistemas. Pagrindiniai tyrimo objektai yra daugialaidès mikrojuostelinès linijos (DML) ir meandrinès mikrojuostelinès vẻlinimo linijos (MMVL). Šie objektai leidžia perduoti, sinchronizuoti bei vèlinti siunčiamus signalus ir yra neatsiejama dalis daugelio mikrobangu prietaisų. Jų operatyvi ir tiksli analizė bei sintezė sąlygoja ịtaisų kūrimo spartinimą. Pagrindinis disertacijos tikslas - sukurti lygiagrečiąsias metodikas ir algoritmus, skirtus sparčiai ir tiksliai atlikti minètų linijų analizę ir sintezę. Sukurtų algoritmų ir metodikų taikymo sritis - mikrobangu įtaisų modeliavimo ir automatizuoto projektavimo programine ịranga.

Disertaciją sudaro ịvadas, penki skyriai, rezultatų apibendrinimas, naudotos literatūros ir autoriaus publikacijų disertacijos tematika sąrašai bei du priedai.

Ivadiniame skyriuje aptariama tiriamoji problema, darbo aktualumas, aprašomi tyrimų objektai, formuluojamas darbo tikslas ir uždaviniai, aprašoma tyrimų metodika, darbo mokslinis naujumas, darbo rezultatų praktinė reikšmé, ginamieji teiginiai. Ivado pabaigoje pristatomos disertacijos tema, autoriaus paskelbtos publikacijos ir pranešimai konferencijose bei disertacijos sandara.

Pirmasis skyrius skirtas literatūros apžvalgai. Jame pateiktos DML ir MMVL analizès ir sintezès problemos, be to apžvelgtos lygiagrečiosios skaičiavimo sistemos ir jų taikymas elektrodinamikos uždaviniams spręsti. Skyriaus pabaigoje formuluojamos išvados ir tikslinami disertacijos uždaviniai. Antrajame skyriuje siūlomi du DML modeliai, leidžiantys skaitiniais metodais apskaičiuoti DML elektrinius parametrus, pateikti siūlomų modelių patikros rezultatai, atitinkantys elektromagnetinius procesus baigtinio dydžio DML. Trečiajame skyriuje plačiau nagrinejjama DML analizė ir sintezè, pasiūlyti lygiagretieji DML analizès ir sintezès algoritmai, atlikta jų patikra. Igyvendinti algoritmai leidžia sparčiau apskaičiuoti elektrinius ir surasti konstrukcinius DML parametrus. Ketvirtajame skyriuje pateikiama lygiagrečioji MMVL dispersinės charakteristikos apskaičiavimo metodika. MMVL dispersinè charakteristika gaunama skaitiniais metodais sprendžiant dispersinę lygti. Lygties sprendiniui rasti buvo sudaryti ir igyvendinti keturi algoritmai. Remiantis šiais algoritmais pasiūlyta ir išbandyta lygiagrečioji MMVL dispersinès charakteristikos apskaičiavimo metodika. Penktasis skyrius skirtas MMVL sintezei. Pasiūlyti ir igyvendinti skiltinio artejjimo ir Monte Karlo metodais grịsti lygiagretieji MMVL sintezès algoritmai, atlikti pasiūlytų algoritmų sintezès tikslumo ir našumo tyrimai. Disertacijos tematika paskelbti 5 straipsniai, iš kurių 3 straipsniai paskelbti recenzuojamuose mokslo žurnaluose. Rezultatai viešinti 9 mokslinèse konferencijose Lietuvoje ir užsienyje. 


\section{Abstract}

The disertation investigates the issues of analysis and synthesis of the microwave devices using parallel computer systems. The main objects of research include microstrip multicunductor lines (MMCL) and meander microstrip delay lines (MMDL). These objects are important to microwave devices, because they let to transmit, sinchronize and delay signals. They fast analysis and synyhesis makes faster device developing. The primary purpose of this dissertation is to create techniqes and algorithms to accelerate analysis and synthesis of the microwave devices.

The dissertation consist of an introduction, five chapters, conclusions, references and two appendixes.

The introduction reveals the investigated problem, importance of the thesis and the object of research, describes the purpose and tasks of the paper, research methodology, scientific novelty, the practical significance of results examined in the paper and defended statements. The introduction ends in presenting the author's publications on the subject of the defended dissertation.

Chapter 1 revised used literature. Here issues of the MMCL and MMDL analysis and synthesis are described, also noted parallel computing systems and their use for the solving of the electromagnetic tasks. At the end of the chapter, conclusions are drawn and the tasks for the dissertation are reconsidered.

At chapter 2 two MMCL models of the limited sizes both based on numerical techniques are proposed. Reseach results of the proposed models which are adequate to electromagnetic processes in the MMCL of the limited sizes are presented also.

Chapter 3 investigates MMCL analysis and synthesis. Here parallel algorithms of the MMCL analysis and synthesis are presented, reseach results of this algorithms are shown also. Purposed algorithms accelerates calculations of electrical or search construction parameters of MMCL.

Chapter 4 investigets dispersion characteristic of MMDL. To calculate dispersion characteristic of the MMDL the dispersion equation should be solved. To search solution of the dispersijon equation four algorithms are purposed, which speed up of the search. The parallel technique to calculate dispersion characteristic of the MMDL is presented also.

Last Chapter 5 investigates several MMDL parallel synthesis algorithms. Parallel algorithms were created using Monte Carlo and coherently approch methods.

The main dissertation results were published in 5 scientific papers, of which 3 papers are published in peer-reviewed scientific journals. Also results were presented in 9 scientific conferences in the Lithuania and abroad. 


\section{Žymèjimai}

\section{Simboliai}

$2 A \quad-\quad$ meandrinio laidininko aukštis, $2 A_{i}^{(P)}-i$-asis meandrinio laidininko aukštis esant $P$ procesų kompiuterių telkinyje; $A$ - meandrinio laidininko aukštis padalintas per pusę;

$C \quad-$ mikrojuostelès ilginè talpa, $C_{i i}-i$-osis mikrojuostelès savoji ilginè talpa, $C_{i j}-$ mikrojuostelių abipusès ilginès talpos;

$c_{0} \quad-\quad$ šviesos greitis vakuume;

E $\quad-$ elektrinio lauko stipris;

G _ - Gryno (angl. Green) funkcija;

$g, f \quad-$ funkcijos;

$H \quad-$ magnetinio lauko stipris;

$h \quad-$ dielektrinio pagrindo storis;

I $\quad-$ srovès amplitudè;

$Y_{0} \quad-$ banginis laidis;

$k \quad-\quad$ verčių ruožo dalinimo koeficientas; 
$k_{\mathrm{L}} \quad-\quad$ lètinimo koeficientas;

$L \quad-$ mikrojuostelès ilginis induktyvumas, $L_{i i}-i$-osis mikrojuostelès savosios ilginis induktyvumas, $L_{i j}$ - mikrojuostelių abipusiai ilginiai induktyvumai;

$l_{\mathrm{m}} \quad-\quad$ meandrinio laidininko ilgis;

$M \quad$ - mikrojuostelès dalinių sričių skaičius;

$N \quad$ - meandro pakopų (laidininkų) skaičius;

$n \quad-$ mikrojuostelès eilès numeris;

$P \quad$ - Procesų, veikiančių kompiuterių telkinyje, skaičius;

$p \quad-$ mazgų (kompiuterių) skaičius kompiuterių telkinyje;

$Q, q \quad-$ elektrinis krūvis;

$S \quad-\quad$ tarpas tarp mikrojuostelių;

$S_{p} \quad-$ lygiagrečiojo algoritmo spartinimo koeficientas;

$t \quad-\quad$ algoritmo vykdymo trukme;

$\varepsilon \quad-$ dielektrinè skvarba, $\varepsilon_{\mathrm{r}}-$ santykinè dielektrinè skvarba,

$\mu_{\mathrm{r}} \quad-\quad$ santykinè magnetinè skvarba;

$t_{\mathrm{v}} \quad-$ sklindančios bangos vèlinimo trukmè, $t_{\mathrm{vzdi}}^{(P)}-$ apskaičiuota $i$-oji vèlinimo trukmè, esant žemiems dažniams ir $P$ procesų kompiuterių telkinyje, $t_{\mathrm{v}}(f)$ - vèlinimo trukmès dažninè charakteristika (dispersinè charakteristika), $t_{\mathrm{v} \text { nom }}-$ vélinimo trukmès nominali verte;

$U \quad-\quad$ itampos amplitude;

$v_{f} \quad-\quad$ elektromagnetinès bangos sklidimo fazinis greitis;

$W \quad-$ mikrojuostelès plotis, $W_{\mu}$ - apskaičiuotas mikrojuostelès plotis, atitinkantis artimiausią charakteringojo impedanso vertę nominaliai, $W_{i}^{(P)}-i$-osis mikrojuostelès plotis, esant $P$ procesų kompiuterių telkinyje;

$W_{\min }, W_{\max }, \quad$ - užsiduotos minimalios ir maksimalios konstrukcinių parametrų $S_{\min }, S_{\max }, \quad$ ribos: atitinkamai mikr

$2 A_{\text {min }}, 2 A_{\text {max }}$

$Z_{0} \quad-$ charakteringasis impedansas, $Z_{0 i}, Z_{0 i}^{(P)}-i$-osios mikrojuostelès charakteringasis impedansas ir charakteringasis impedansas, esant $P$ procesams kompiuterių telkinyje, $Z_{0 \mathrm{~L}, \mathrm{~N}}$ - charakterin- 
gasis impedansas lyginio ir nelyginio sužadinimo atvejais, $Z_{0}(f)$-charakteringojo impedanso dažninè charakteristika, $Z_{0 \text { nom }}$ - charakteringojo impedanso nustatytoji nominali verté;

$\beta_{0} \quad-\quad$ elektromagnetinès bangos fazės koeficientas vakuume;

$\Delta F \quad-$ praleidžiamųų dažnių juosta, $\Delta F_{\text {nom }}$ - praleidžiamujų dažnių juostos nominali verte;

$\Delta S_{p} \quad-$ lygiagrečiojo algoritmo spartos didejjimo koeficientas;

$\Delta W, \Delta S, \quad$ - kitimo žingsnis atitinkamai mikrojuostelès pločio, tarpo tarp mik$\Delta A \quad$ rojuostelių ir meandrinio laidininko aukščio;

$\delta \quad-\quad$ leistina skaičiavimo nuokrypa, $\delta^{\prime}-$ apskaičiuotų verčių santykinis skirtumas, $\delta_{i}-i$-ojo parametro leistina nuokrypa;

$\theta \quad-$ gretimų meandro mikrojuostelių fazių skirtumas, $\theta_{i}-i$-oji fazès vertè, $\Delta \theta$ - fazès kitimo žingsnis;

$\varphi \quad-\quad$ elektrinis potencialas.

\section{Santrumpos}

DML

- daugialaidè mikrojuostelinè linija (angl. $M M C L$ - microstrip multiconductor line);

LI $\quad-\quad$ lètinimo ịtaisas;

MMVL $\quad-\quad$ meandrinè mikrojuostelinè vèlinimo linija;

PSS $\quad-\quad$ pranešimų siuntimo sąsaja;

BS metodas $\quad-\quad$ baigtinių skirtumų metodas;

TEM _ - (angl. trensverse electromagnetic) - skersinè elektromagnetinè banga neturinti elektrinès ir magnetinès dedamosios sklidimo kryptimi;

CPI $\quad-\quad$ centrinis procesorinis ịrenginys;

DFCh _ - dažninè fazès charakteristika. 



\section{Turinys}

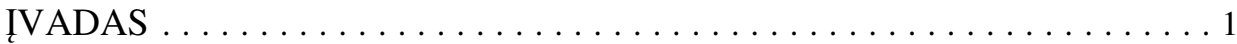

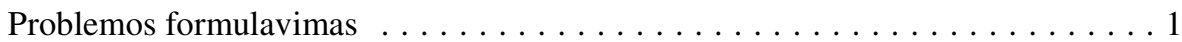

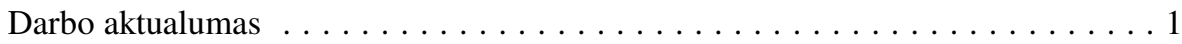

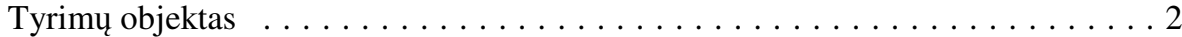

Darbo tikslas . . . . . . . . . . . . . . . . . . . . . . 2

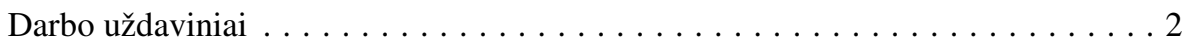

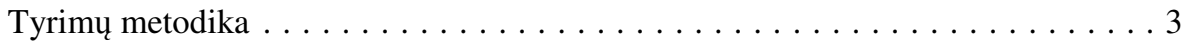

Darbo mokslinis naujumas ir jo reikšmè $\ldots \ldots \ldots \ldots \ldots \ldots \ldots \ldots \ldots$

Darbo rezultatu praktinè reikšmė $\ldots \ldots \ldots \ldots \ldots \ldots \ldots \ldots \ldots \ldots \ldots$

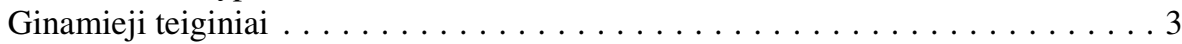

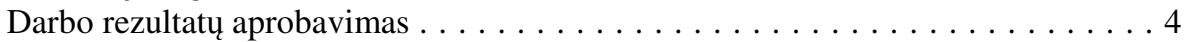

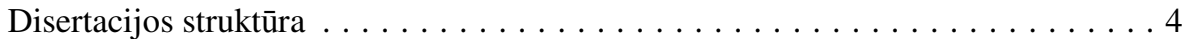

1. MIKROJUOSTELINIŲ LĖTINIMO IৃTAISŲ ANALIZĖS IR SINTEZE்

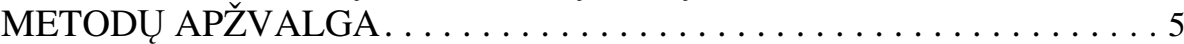

1.1. Lètinimo įtaisų modeliavimas ir tyrimas $\ldots \ldots \ldots \ldots \ldots \ldots \ldots \ldots$

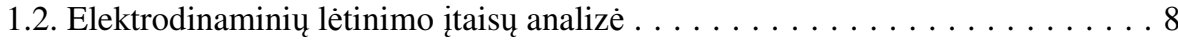

1.3. Skaitiniai elektromagnetizmo analizès metodai $\ldots \ldots \ldots \ldots \ldots \ldots \ldots 11$

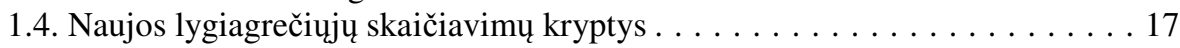

1.5. Lygiagrečiujų sistemų taikymas elektromagnetizmo uždaviniams spręsti . . . 21

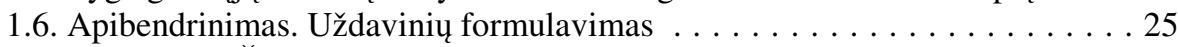

2. DAUGIALAIDŽIŲ MIKROJUOSTELINIŲ LINIJŲ MODELIAI. . . . . . . . 27

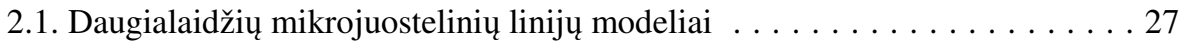

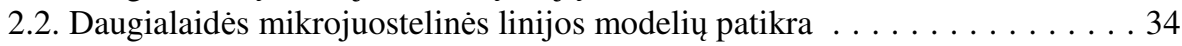

2.3. Daugialaidès mikrojuostelinès linijos modelių tyrimas . . . . . . . . . 37 


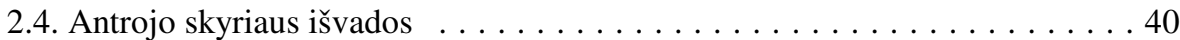

3. LYGIAGREČIOJI DAUGIALAIDŽIŲ MIKROJUOSTELINIŲ LINIJŲ ANALIZĖS IR SINTEZE் . . . . . . . . . . . . . . . . . . . . 43

3.1. Daugialaidès mikrojuostelinès linijos analizè $\ldots \ldots \ldots \ldots \ldots \ldots 43$

3.1.1. Lygiagretusis daugialaidès mikrojuostelinès linijos analizès algoritmas. 45

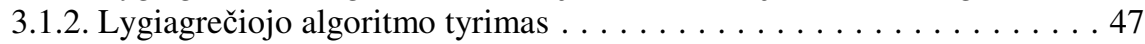

3.2. Daugialaidès mikrojuostelinès linijos sintezè $\ldots \ldots \ldots \ldots \ldots \ldots \ldots 52$

3.2.1. Periodinès daugialaidès mikrojuostelinès linijos modelis . . . . . . . 52

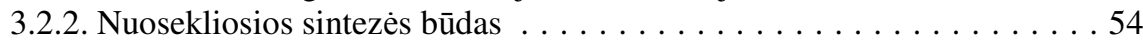

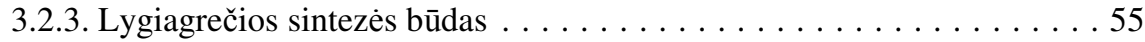

3.2.4. Sintezès algoritmo patikra $\ldots \ldots \ldots \ldots \ldots \ldots \ldots \ldots \ldots \ldots$

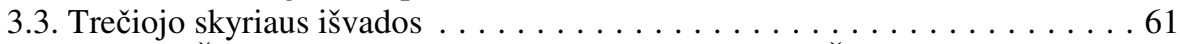

4. LYGIAGREČIOJI VĖLINIMO TRUKMĖS APSKAIČIAVIMO

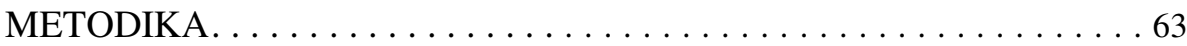

4.1. Meandrinių mikrojuostelinių vèlinimo linijų analizè $\ldots \ldots \ldots \ldots \ldots 63$

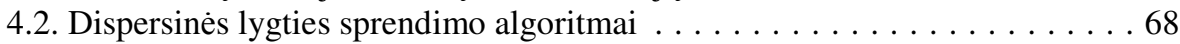

4.3. Lygiagrečioji meandrinès mikrojuostelinès vèlinimo linijos analizès

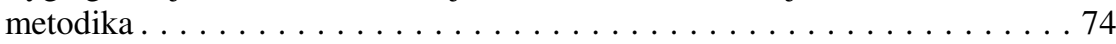

4.4. Lygiagrečiosios meandrinių mikrojuostelinių vèlinimo linijų dažninių

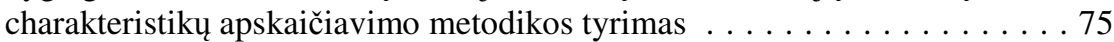

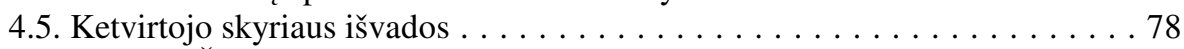

5. LYGIAGREČIOJI MEANDRINIŲ MIKROJUOSTELINIŲ LINIJŲ

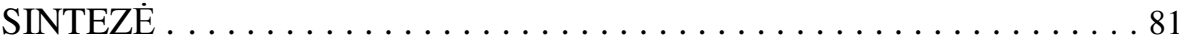

5.1. Meandrinių mikrojuostelinių vèlinimo linijų lygiagrečiosios sintezès

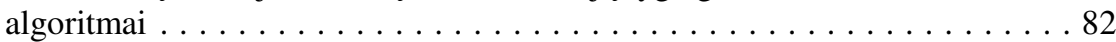

5.1.1. Monte Karlo metodu grịsti meandrinių mikrojuostelinių vèlinimo linijų

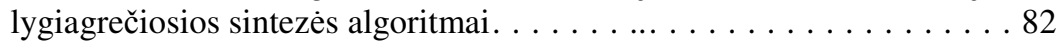

5.1.2. Skiltinio artèjimo metodu grịsti meandrinių mikrojuostelinių vèlinimo

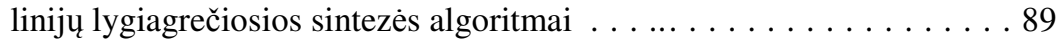

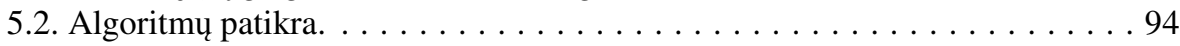

5.2.1. Matematinio modelio adekvatumo patikra . . . . . . . . . 94

5.2.2. Meandrinių mikrojuostelinių vèlinimo linijų lygiagrečiosios sintezès

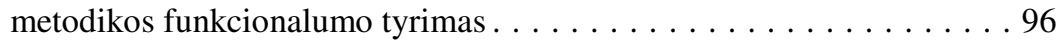

5.2.3. Meandrinių mikrojuostelinių vèlinimo linijų lygiagrečiosios sintezès

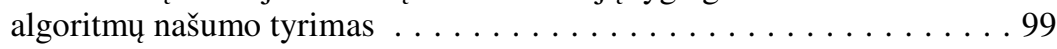

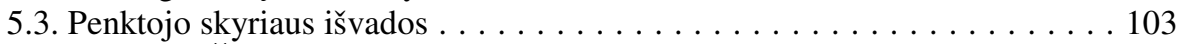

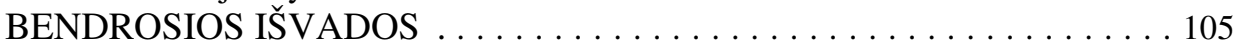

LITERATŪRA IR ŠALYINIAI. . . . . . . . . . . . . . . . . . . . . 107

AUTORIAUS PUBLIKACIJOS DISERTACIJOS TEMA $\ldots \ldots \ldots \ldots \ldots 121$

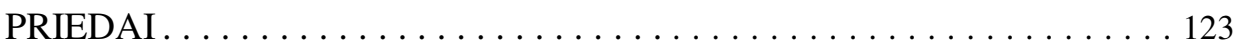

A priedas. Daugialaidžių mikrojuostelinių linijų matematinis modelis grịstas baigtinių skirtumų metodu . . . . . . . . . . . . . . . 123

B priedas. Daugialaidžių mikrojuostelinių linijų matematinis modelis grįstas momentų metodu . . . . . . . . . . . . . . . . . 130 


\section{Contents}

INTRODUCTION $\ldots \ldots \ldots \ldots \ldots \ldots \ldots \ldots \ldots \ldots \ldots \ldots \ldots \ldots$

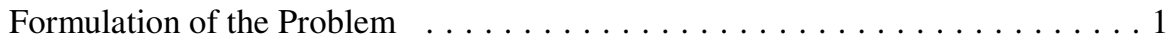

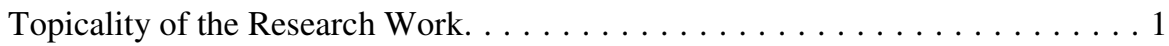

Research Object ............................. 2

The Aim of Work . . . . . . . . . . . . . . . . . . . . . 2

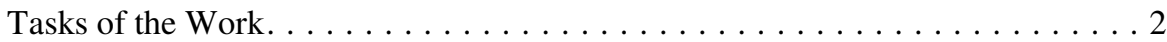

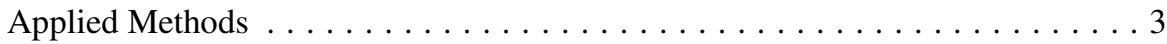

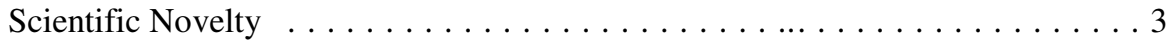

Links with Scientific Programmes $\ldots \ldots \ldots \ldots \ldots \ldots \ldots \ldots \ldots \ldots \ldots$

The Defended Statements . . . . . . . . . . . . . . . . . 3

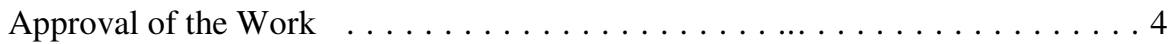

The Scope of the Scientific Work . . . . . . . . . . . . . . . 4

1. REVIEW OF THE METHODS OF ANALYSIS AND SYNTHESIS OF THE MEANDER RETARD DEVICES $\ldots \ldots \ldots \ldots \ldots \ldots \ldots \ldots \ldots$

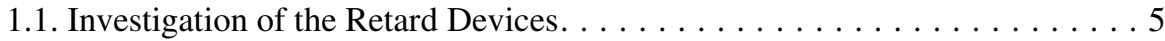

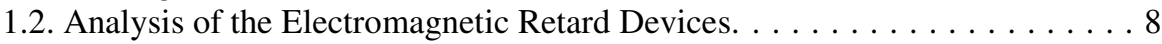

1.3. Numerical Methods Used for Electromagnetic Analysis . . . . . . . . . . 11

1.4. New Directions of the Parallel Cumputations . . . . . . . . . . . . 17

1.5. Solving Electromagnetic Tasks Using Parallel Systems. . . . . . . . 21

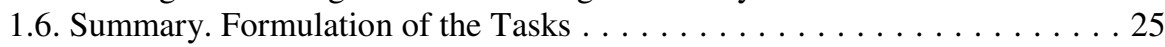

2. MODELS OF THE MICROSTRIP MULTICONDUCTOR LINE.. . . . . . . 27

2.1. Models of the Microstrip Multiconductor Line $\ldots \ldots \ldots \ldots \ldots \ldots 27$ 
2.2. Revise of the Models of Microstrip Multiconductor Line. . . . . . . . . . . . 34

2.3. Investigation of the Models of Microstrip Multiconductor Line . . . . . . . . 37

2.4. Conclusions of the Second Chapter . . . . . . . . . . . . . . 40

3. PARALLEL ANALYSIS AND SYNTHESIS OF THE MICROSTRIP MULTICONDUCTOR LINE $\ldots \ldots \ldots \ldots \ldots \ldots \ldots \ldots \ldots \ldots \ldots$

3.1. Analysis of the Microstrip Multiconductor Lines . . . . . . . . . . 43

3.1.1. Parallel Analysis Algorithm of the Microstrip Multiconductor Line . . . 45

3.1.2. Investigation of the Parallel Algorithm . . . . . . . . . . . . 47

3.2. Synthesis of the Microstrip Multiconductor Line . . . . . . . . 52

3.2.1. Periodical Model of the Microstrip Multiconductor line . . . . . . . 52

3.2.2. Sequential Synthesis Method $\ldots \ldots \ldots \ldots \ldots \ldots \ldots \ldots \ldots$

3.2.3. Parallel Synthesis Method $\ldots \ldots \ldots \ldots \ldots \ldots \ldots \ldots \ldots$

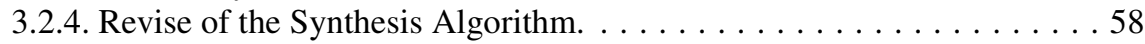

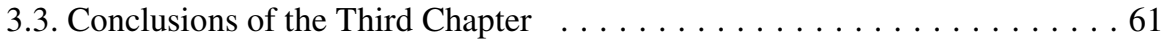

4. PARALLEL TECHNIQUE OF THE DELAY TIME COMPUTATION . . . 63

4.1. Analysis of the Meander Microstrip Delay Line $\ldots \ldots \ldots \ldots \ldots \ldots 6$

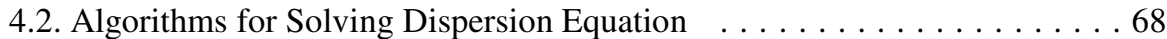

4.3. Parallel Analysis Technique of the Meander Microstrip Delay Line . . . . . 74

4.4. Investigation of the Parallel MMCL Frequency Characteristic Computation Technique . . . . . . . . . . . . . . . . . . . . . 75

4.5. Conclusions of the Fourth Chapter $\ldots \ldots \ldots \ldots \ldots \ldots \ldots \ldots$

5. PARALLEL SYNTHESIS OF THE MEANDER MICROSTRIP DELAY

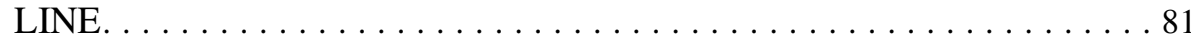

5.1. Parallel Synthesis Algorithms of the Meander Microstrip Delay Line . . . . 82

5.1.1. Implementation of the Parallel Synthesis Algorithm of the Meander Microstrip Delay Line using Monte Carlo Method . . . . . . . . . 82

5.1.2. Implementation of the Parallel Synthesis Algorithm of the Meander Microstrip Delay Line Using Successive Aproximation Method . . . 89

5.2. Investigation of the Algorithms . . . . . . . . . . . . . . . . 94

5.2.1. Revise of the Accuracy of the Mathematical Model . . . . . . . .994

5.2.2. Investigation of Functionality of the Parallel Synthesis Technique of the Meander Microstrip Delay Line . . . . . . . . . . . . . . . . 96

5.2.3. Investigation of effectivenes of the parallel synthesis algorithms of the Meander Microstrip Delay line. . . . . . . . . . . . . . . . . . . 99

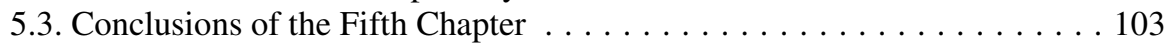

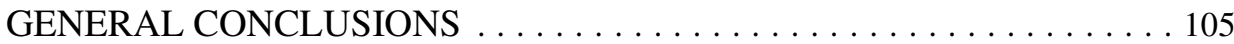

REFERENCES . . . . . . . . . . . . . . . . . . . . . . . . . . . 108

LIST OF THE AUTHOR'S SCIENTIFIC PUBLICATIONS ON

THE TOPIC OF DISSERTATION . . . . . . . . . . . . . . . . . . . 121

APPENDIX . . . . . . . . . . . . . . . . . . . . . . . . 123

A appendix. Multiconductor microstrip line mathematical model based on finite difference method . . . . . . . . . . . . 123

B appendix. Multiconductor microstrip line mathematical model based on method of moments . . . . . . . . . . . . . . . . . . 130 


\section{Ivadas}

\section{Problemos formulavimas}

Skaitinių metodų taikymas analizuojant mikrobangu įtaisus leidžia tiksliai apskaičiuoti jų elektrinius parametrus ir charakteristikas, tačiau tuo pačiu reikalauja didelių skaičiavimo resursų ir skaičiavimai trunka ilgai. Spartus kompiuterių technologijų ir programinès įrangos tobulejjimas kartu su skaitinių metodų pritaikymu sudaré sąlygas sparčiam mikrobangų ịtaisų modeliavimui kompiuteriais.

Šiuo metu siūloma nemažai universalios komercinès ir laisvai platinamos programinès įrangos mikrobangų įtaisams modeliuoti. Tačiau norint analizuoti ir projektuoti mikrobangų ịtaisus tenka prisitaikyti prie siūlomos programinès ịrangos galimybių ir veikimo spartos. Taip pat nèra siūloma programinè ịranga leidžianti išnaudoti šiuolaikinę lygiagrečiają skaičiavimo techniką.

\section{Darbo aktualumas}

$\mathrm{XX}$ a. viduryje mikrobangų įtaisai buvo projektuojami taikant eksperimentinius ir analitinius metodus. Mikrobangų ịtaisų analizė skaitiniais metodais yra tikslesnè ir turi mažiau apribojimų nei analitinè, tačiau analizuojant realius ịtaisus skaičiavimai gali trukti 17 valandų net naudojant pajėgias darbo stotis. 
Spartejant ir tobulejjant kompiuterinei technikai, atsiranda vis didesnių galimybių taikyti skaitinius metodus elektrodinamikos uždaviniams spręsti ir kurti sudètingesnius mikrobangu ịtaisų modelius. Tačiau ir šiuolaikiniai kompiuteriai leidžia pasiekti užsibrèžtų tikslų. Šiuo atveju galima pasinaudoti kompiuterių telkiniais arba šiuo metu kuriamomis ir gaminamomis specialiomis kompiuterių komponentėmis, kurios leidžia paskirstyti sprendžiamą uždavinį.

Uždavinio paskirstymas prad ėtas taikyti praktiškai nuo pirmujų kompiuterių atsiradimo, tačiau tai buvo specialios darbo stotys ir jų naudojimas bei galimybès buvo ribotos. Maždaug nuo XX a. dešimto dešimtmečio vidurio pasirode technologijos leidžiančios paskirstyti uždavinius tarp asmeninių kompiuterių, taip suteikiant galimybę visiems norintiems pasinaudoti paskirstytujjų skaičiavimų galimybėmis. Šiuo metu tai tapo ypač populiaru, nes prieš kelis metus pradèti gaminti bendrosios paskirties centriniai procesoriniai įrenginiai, grafiniai procesoriai ir specialiosios paskirties mikroprocesoriai, kuriuose yra daugiau nei vienas skaičiavimams skirtas įrenginys.

Skaičiavimo technikos pajègumai ir galimybès nuolat didèja, tačiau mikrobangų ịtaisų analizès ir sintezės metodikos ir algoritmai per pastaraji dvidešimtmeti praktiškai nepakito. Tačiau, siekiant igyvendinti naujus mikrobangų ịtaisu modelius automatizuoto projektavimo sistemose būtina išspręsti esminę problema - elektrodinaminiu lètinimo ịtaisu analize ir sinteze taikant lygiagrečiasias kompiuterines sistemas.

\section{Tyrimų objektas}

Darbo tyrimų objektas - daugialaidès mikrojuostelinès linijos (DML) ir meandrinès mikrojuostelinès vèlinimo linijos (MMVL).

\section{Darbo tikslas}

Šio darbo tikslas ištirti galimybę, naudojant lygiagrečiąsias kompiuterines sistemas meandrinių mikrojuostelinių lètinimo sistemų projektavimui, sukuriant ir ištiriant daugialaidžių mikrojuostelinių struktūrų lygiagrečiosios analizès ir sintezès metodikas.

\section{Darbo uždaviniai}

Darbo tikslui pasiekti darbe reikia spręsti šiuos uždavinius:

1. Pasiūlyti DML modelius tinkamus baigtinio dydžio MMVL analizuoti.

2. Sukurti ir ištirti lygiagrečiają DML analizès metodiką.

3. Sukurti ir ištirti MMVL dispersinès charakteristikos lygiagrečiają apskaičiavimo metodiką. 
4. Sukurti ir ištirti MMVL lygiagrečiają sintezès metodiką.

\section{Tyrimų metodika}

Darbe taikomi: baigtinių skirtumų analizès skaitinis metodas, dispersinės lygties sprendinio paieškos skaitiniai metodai bei mažiausių kvadratų tiesinių lygčių sprendimo metodas.

\section{Darbo mokslinis naujumas}

Rengiant disertaciją buvo gauti šie elektros ir elektronikos inžinerijos mokslui nauji rezultatai:

1. Pasiūlyti ir igyvendinti nauji DML modeliai, tinkami baigtinio dydžio MMVL analizei.

2. Sukurta ir ištirta lygiagrečioji DML analizès metodika.

3. Sukurta ir ištirta MMVL dispersinès charakteristikos lygiagrečioji apskaičiavimo metodika.

4. Sukurta ir ištirta MMVL lygiagrečioji sintezès metodika.

\section{Darbo rezultatų praktinė reikšmė}

Tyrimų rezultatai gali būti naudojami analizuoti ir kurti ịvairius mikrobangų įtaisus, kurių analizè pagrịsta daugialaidėmis mikrojuostelinėmis linijomis, o taip pat yra sukurtos metodikos, leidžiančios išnaudoti lygiagrečiųjų kompiuterinių sistemų pajégumus, paspartinant DML ir MMVL analizès ir sintezès procesus.

\section{Ginamieji teiginiai}

1. Sudarytieji skaitiniai DML ir MMVL modeliai leidžia tiksliau apskaičiuoti jų elektrines charakteristikas nei modeliai grịsti empirinèmis išraiškomis ir konforminių keitimų metodu.

2. Pasiūlyti baigtinio dydžio DML matematiniai modeliai atskleidžia elektrinių parametrų nereguliarumą skersiniame DML pjūvyje.

3. DML veikiančios normaliụjų bangų režimu, vidinių mikrojuostelių elektromagnetinio lauko pasiskirstymas gali skirtis nuo vienalytės mažiau nei $0,1 \%$. 
4. Sudarytos ir igyvendintos lygiagrečiosios DML ir MMVL analizės metodikos leidžia iki 4 kartų paspartinti skaičiavimo procesą.

5. Lygiagretieji algoritmai, grissti skiltinio artejjimo metodu, leidžia iki 8 kartų sparčiau atlikti MMVL sintezę lyginant su Monte Karlo metodu grịstais algoritmais.

\section{Darbo rezultatụ aprobavimas}

Disertacijos tema paskelbti 5 straipsniai, iš kurių 3 straipsniai paskelbti recenzuojamuose mokslo žurnaluose

Disertacijoje atliktų tyrimų rezultatai buvo paskelbti 9 mokslinėse konferencijose Lietuvoje ir užsienyje:

- R. Pomarnacki, 2008. Elektrodinamikos uždaviniu sprendimo metodai. Mokslas - Lietuvos ateitis. Vilnius.

- R. Pomarnacki, V. Urbanavičius. 2008. Study of microstrip multiconductor line. Electromagnetic disturbances EMD 2008. Vilnius.

- R. Pomarnacki. 2009. Dispersinés lygties sprendimo galimybès. Mokslas - Lietuvos ateitis. Vilnius.

- R. Pomarnacki, V. Urbanavičius. 2009. Parallel system for the analysis of meander delay line. IC-Speto 2009. Ustron, Lenkija.

- R. Pomarnacki, V. Urbanavičius, A. Gurskas. 2009. Parallel calculation of the dispersion equation of meneander delay line. Elektronika 2009. Vilnius.

- R. Pomarnacki. 2010. Mikrojuostelinès linijos charakteristiku skaičiavimas lygiagrečiuoju būdu. Mokslas - Lietuvos ateitis. Vilnius.

- R. Pomarnacki, A. Krukonis, V. Urbanavičius. 2010. Parallel algorithm for the quasi-TEM analysis of microstrip multiconductor line. Elektronika 2010. Vilnius.

- R. Pomarnacki. 2011. Vélinimo liniju sintezé taikant Monte Karlo metoda. Mokslas - Lietuvos ateitis. Vilnius. Respublikinè.

- R. Pomarnacki, V. Urbanavičius, A. Gurskas. 2011. Parallel synthesis of the meander delay line. Elektronika 2011. Vilnius.

\section{Disertacijos struktūra}

Disertaciją sudaro įvadas, penki skyriai ir bendrosios išvados.

Darbo apimtis yra 149 teksto puslapiai, tekste panaudotos 69 numeruotos formulès, 44 paveikslai ir 16 lentelių. Rašant disertaciją buvo panaudota 155 literatūros šaltiniai. 


\section{1}

\section{Mikrojuostelinių lètinimo ịtaisu analizès ir sintezès metodų apžvalga}

Šiame skyriuje apžvelgiamos lètinimo įtaisų (LI) konstrukcijos, LI taikymo sritys, meandrinių LI analizès metodai, atskleidžiamos lygiagrečiai sprendžiamos elektromagnetizmo problemos, nagrinèjamos meandrinių LI automatizuoto projektavimo metodikos, suformuluojami disertacinio darbo tikslas ir uždaviniai.

\subsection{Lètinimo ịtaisų modeliavimas ir tyrimas}

Elektronikoje plačiai taikomi lètinimo įtaisai, kurių paskirtis trumpam laikui ịsiminti ị juos pasiųstą elektrinị signalą. Lètinimo ịtaisai taikomi ịvairiuose vèlinimo linijose, elektronų kreipimo sistemose, filtruose, šakotuvuose, elektroniniuose bėgančios bangos vamzdžiuose ir kitur.

Lètinimo ịtaisu vadiname įtaisą, kurị sudaro lètinimo sistema, korpusas ir ịvesties bei išvesties ịvadai. Lètinimo įtaisu galime vadinti paskirstytuju parametrų ịtaisą, skirtą signalo sklidimo sulètinimui. Šiuo metu lètinimo ịtaisuose naudojamos plačiajuostès bedispersinès ir dispersinès, fiksuotos ir keičiamos vẻlinimo trukmès lètinimo sistemos. 
Planariaisiais letinimo įtaisais vadiname plokščios konstrukcijos lètinimo įtaisus. Jie gali būti gaminami pagal standartines daugiasluoksnių spausdintinių plokščiu arba plèvelinių integrinių grandynų technologijas. Pastaruoju atveju gaunami ypač kompaktiški ir technologiški lètinimo įtaisai. Planarinių spiralinių LI konstrukcija bei gamybos technologija yra pakankamai sudètingos. Standartinèmis šiuolaikinėmis gamybos technologijomis galima pagaminti tik ištęsto stačiakampio skerspjūvio planarines spiralines sistemas. Standartine storasluoksne arba plonasluoksne integrinių grandynų technologija gaminami spiraliniai lètinimo įtaisai nepasiteisino (Kirvaitis 1994; Вайнорис et al. 1986). Śiai technologijai gerai tinka įvairių konstrukcijų meandriniai, juosteliniai bei mikrojuosteliniai lètinimo ịtaisai, todèl paskutiniame dvidešimtmetyje netechnologiškus spiralinius lètinimo ịtaisus praktiškai visur, išskyrus kreipimo įtaisus, keičia meandrinès ir kitokios planarinès lètinimo sistemos (Štaras et al. 2010; Preradovic et al. 2009; Kuylenstierna et al. 2005). Geriausiai integrinio grandyno pagrindo plotas panaudojamas mikrojuosteliniuose, dviekraniuose ir daugiasluoksniuose meandriniuose LI (Moloratsky 2011; Terada et al. 2008).

Meandriniu vadinamas toks elektromagnetinių bangų perdavimui skirtas itaisas, kuriame bent vienas laidininkas turi meandro formą (1.1 pav.). Meandrinis laidininkas paprastai yra plokščias. Šiuose įtaisuose gali būti vienas arba du ištisiniai ekranai. Erdvę tarp meandrinio laidininko ir ekranų užpildo vienalytis arba sluoksniuotas magnetodielektrikas. Bendras ịvairių meandrinių lėtinimo įtaisų bruožas yra plokščia (planarinė) jų konstrukcija. Todèl jie priskiriami prie planarinių elektrodinaminių lètinimo ịtaisų. Meandrinių Lİ konstrukcija santykinai nesudètinga, jie yra technologiški ir gali būti gaminami pagal standartinę plèvelinių integrinių grandynų technologiją. Mikrojuostelè suformuojama ant vienos dielektrinio pagrindo pusès standartine plevelinių integrinių grandynų gamybos technologija, kita pagrindo pusé - ištisai metalizuojama, tokiu būdu pagamintas lètinimo ịtaisas vadinama meandrine mikrojuosteline linija.

Meandrinių lètinimo įtaisų konstrukcijos gali būti labai ịvairios (Kabiri et al. 2010; Steindl et al. 1998). Meandrinio laidininko matmenys išilgai viso lètinimo įtaiso gali būti vienodi, arba turèti periodiškai pasikartojančius laidininko susiaurejjimus bei praplatējimus.

Didžiausioji meandrinių LI modelių dalis sukurta daugialaidžių linijų metodu (Gonzalez et al. 2010; Greda, Pregla 2003; Hashish, Saker 2005). Matematiniai įtaisų modeliai reikalingi tam, kad ịtaisų analizès procesą perkelti kompiuterių programoms tuo pačiu atsisakant rankinio skaičiavimo ir spartinant lètinimo ịtaisų projektavimo procesą.

Meandrinių LI gamybai geriausiai tinka standartinè plèvelinių integralinių schemų gamybos technologija, todèl dauguma sukurtų modelių skirta meandrinių mikrojuostelinių LI analizei (Urbanavičius et al. 2009). 
Pirmoji meandrinė LI buvo aprašyta 1950 metais (Pierce 1950). Tai buvo zigzagu forma sulankstytos dvilaidès linijos. Vèliau sudètingesnès konstrukcijos meandriniai LI buvo plačiai naudojami superaukštojo dažnio stiprintuvuose (Rowe 1956). Pirmieji darbai apie meandrinių LI savybių analizę paskelbti tik XX a. septintajame dešimtmetyje (Силин et al. 1966; Тараненка et al. 1965).

Iki 1980 metų praktiškai nèra darbų, kuriuose būtų nagrinèjamas planarinių meandrinių sistemų taikymas kuriant bedispersinius plačiajuosčius Lİ. Šio laikotarpio darbuose aprašomi dispersiniai meandriniai LI (Kowalski 1974), skirti ryšio kanalo grupinès vẻlinimo trukmès dažninès charakteristikos korekcijai ir siaurajuosčiai meandriniai LI - fazès keitikliai, varžų transformatoriai ir antenų elementai.

XX a. devintajame dešimtmetyje sukuriami pirmieji meandriniai bedispersiniai fiksuotos, keičiamos ir programuojamos vèlinimo trukmès ịtaisai (1.1 pav.) esant $20 \mathrm{~ns}$ vèlinimo trukmei, pasiektas $300 \mathrm{MHz}$ pralaidumo juostos plotis, o esant 4 ns vèlinimo trukmei, gaunama $1 \mathrm{GHz}$ pralaidumo juosta. Minèti LI skirti naudoti $50 \Omega$ signaliniuose traktuose. Šiuose įtaisuose numatytas diskretus vèlinimo trukmès keitimas kas 0,1 ns (Гурскас 1991).

Pastaruoju metu meandriniai LI tampa plačiai naudojamu elementu rezonansinèse ir bėgančiosios bangos antenose (Marrocco 2003; Losito 2007), filtruose (Vincent et al. 2003) ir kituose ịrenginiuose (Tharp et al. 2006; Chen et al. 2009). Sukurtos meandrinès vèlinimo sistemos, kurios taikomos optoelektronikoje (Wang et al. 2007). Meandrinių sistemų taikymas leidžia sukurti mažų gabaritų mikrobangų ịtaisus, todèl jos naudojamos ten, kur miniatiūrizacijos klausimai yra gyvybiškai svarbūs, pvz., (Chamarti, Varahmayan 2006) darbe pranešama apie meandrinių LI panaudojimą, gaminant RFID (angl. radio frequency identification - identifikavimas radijo bangomis) įrenginius.

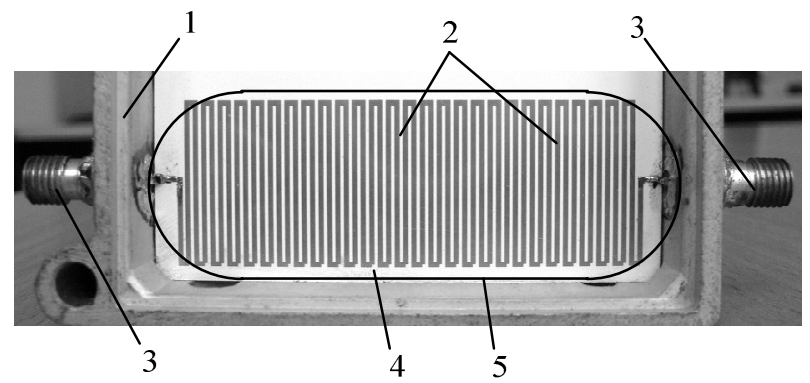

1.1 pav. Meandrinès mikrojuostelinės vèlinimo linijos konstrukcijos pavyzdys, čia: 1 - korpusas, 2 - mikrojuostelès, 3 - išvadai, 4 - dielektrinis pagrindas, 5 - meandrinè mikrojuostelinè linija

Fig. 1.1. An example of construction of the meander microstrip delay line, here: 1 - case, 2 - microstrips, 3 - ports, 4 - conducting shield, 5 - meander microstrip line 
Panaudojant naujausias technologijas, galima viename mikroschemos korpuse kartu gaminti analogines mikrobangines ir skaitmenines schemas, todèl meandrinių LI taikymo sritys turètų plèstis.

1965 metais elektrodinaminès vẻlinimo, lètinimo ir kreipimo ịtaisai pradèti sistemingai tirti Lietuvoje, t. y. Kauno politechnikos instituto Vilniaus filiale (dabar Vilniaus Gedimino Technikos Universitetas) prof. Z. Vainorio suburtoje mokslininkų grupeje. Čia pradètos analizuoti spiralinès sistemos. Taikant elektrodinaminị metodą buvo sudaryti apvalaus ir stačiakampio skerspjūvio spiralinių sistemų apibendrinti modeliai, išvestos dispersinès lygtys, gautos charakteringojo impedanso, ilginès talpos ir ilginio induktyvumo išraiškos. Tuo pačiu metu buvo išvestos spiralinių sistemų su juostine spirale ir elipsinių spiralinių sistemų dispersinès lygtys, ištirtos spiralinių sistemų su pasukta vija savybės, ịvertinta ekranų ir daugiasluoksnio dielektriko įtaka. Taikant daugialaidžių linijų metodą, tirtos nesimetrinès ir simetrinès spiralinès ir meandrinès lètinimo ir kreipimo sistemos. Spiralinès sistemos nagrinètos ir kaip plačiajuostės vèlinimo linijos, ir kaip lètinimo ir kreipimo sistemos bėgančiosios bangos elektroniniuose vamzdžiuose. Rezultatai publikuoti ịvairiuose leidiniuose, detaliau aprašyti mokslininkų disertacijose ir apibendrinti mokslinėje monografijoje (Štaras et al. 2010). Prie elektrodinaminių lètinimo sistemų tyrimo ir jų taikymo elektroniniuose prietaisuose problemos sprendimo daug prisidejo profesoriai S. Štaras, R. Martavičius, R. Kirvaitis, J. Skudutis, docentai A. Gurskas, V. Urbanavičius, A. Jurjevas V. Daškevičius ir T. Burokas.

\subsection{Elektrodinaminiụ lètinimo ịtaisụ analizè}

Elektrodinaminis LI gali būti apibūdinamas dažninėmis ir laiko charakteristikomis. Pagrindinès dažninės charakteristikos yra charakteringojo impedanso $Z_{0}(\omega)$ arba ịejimo impedanso $Z_{\mathrm{IN}}(\omega)$ priklausomybė nuo dažnio ir kompleksinė dažninè charakteristika:

$$
K(j \omega)=\frac{U_{\text {OUT }}}{U_{\text {IN }}}=K(\omega) \mathrm{e}^{j \varphi(\omega)},
$$

čia $U_{\text {OUT }}$ ir $U_{\text {IN }}$ - ịtampos kompleksinès amplitudès LI išèjime ir ịejime; $K(\omega)$ - dažninė amplitudès charakteristika (DACh); $\phi(\omega)$ - dažninė fazès charakteristika (DFCh); $\omega=2 \pi f$ - kampinis dažnis; $f$ - ciklinis dažnis.

Kai lètinimo sistemoje nèra netolygumų ir ji suderinta su apkrova, 


$$
K(\omega)=\mathrm{e}^{-\alpha(\omega) t}, \phi(\omega)=\beta(\omega) l,
$$

čia $\alpha(\omega)$ ir $\beta(\omega)$ - dažninès slopinimo ir fazės koeficientų priklausomybès; $l$ - lètinimo įtaiso ilgis.

Realių LI signalų traktuose neišvengiama netolygumų, o jų charakteringieji impedansai ir apkrovos varžos dydžiai kinta, kintant dažniui. Todèl (1.2) išraiškos būna daug sudètingesnès.

Laiko ašyje LI savybės aprašomos pereinamaja $h(t)$ arba impulsine $g(t)$ charakteristikomis, kurių ryšys su dažninėmis charakteristikomis yra toks:

$$
\begin{gathered}
h(t)=\frac{K(0)}{2}+\frac{1}{\pi} \int_{0}^{\infty} \frac{K(\omega)}{\omega} \sin [\omega t+\phi(\omega)] \mathrm{d} \omega, \\
g(t)=\frac{1}{2 \pi} \int_{0}^{\infty} K(\mathrm{j} \omega) \mathrm{e}^{\mathrm{j} \omega t} \mathrm{~d} \omega .
\end{gathered}
$$

Pereinamoji ir impulsinè charakteristikos vaizdžiai parodo perduodamų per LI impulsų formos iškraipymus, tačiau nepaaiškina jų priežasties. Iškraipymų priežasties nustatymui, naudojamos dažninès lètinimo ịtaiso charakteristikos.

Analizuojant lètinimo ịtaisus, dažniausiai matuojamos ir skaičiuojamos ne DFCh, bet jos išvestinès charakteristikos - dažninès fazinès ar grupinès vẻlinimo trukmès priklausomybès:

$$
t_{\mathrm{v}}(\omega)=\frac{\phi(\omega)}{\omega}=\frac{l}{v_{\mathrm{f}}(\omega)}, t_{\mathrm{gr}}(\omega)=\frac{d \phi(\omega)}{d \omega}=\frac{l}{v_{\mathrm{gr}}(\omega)},
$$

čia $v_{\mathrm{f}}(\omega)$ ir $v_{\mathrm{gr}}(\omega)$ - elektromagnetinès bangos sklidimo išilgai LI fazinio ir grupinio greičių priklausomybès nuo dažnio.

Pagal vėlinimo trukmès dažninès fazinès priklausomybès pobūdị lètinimo sistemos skirstomos ị bedispersines ir dispersines. Plačiajuosčiuose LI naudojamos bedispersinès lètinimo sistemos. Šiomis sistemomis perduodamų virpesių forma pakinta nedaug.

Ideali bedispersinè sistema turi pralaidumo juostoje pastovią vèlinimo trukmę, perdavimo koeficientą ir charakteringaji impedansą, todėl neiškraipo perduodamo signalo formos, kai jo spektras neišeina už LI pralaidumo juostos ribų. Realių bedispersinių Lİ dažninès charakteristikos turi tenkinti standartinius reikalavimus: pralaidumo juostoje DACh turi išlikti $3 \mathrm{~dB}$ ribose, o DFCh nuokrypis nuo tiesinès, einančios per koordinačių pradžią charakteristikos turi nevir- 
šyti 0,35 radiano (Вайнорис et al. 1986). Bedispersinès LI fazinès vėlinimo trukmės dažninè priklausomybė $t_{\mathrm{v}}(\omega)$ turi tenkinti tokią sąlygą:

$$
\Delta t_{\mathrm{v}} \leq \frac{0,35}{\omega},
$$

čia $\Delta t_{\mathrm{v}}=t_{\mathrm{v}}(\omega)-t_{\mathrm{vZD}}, t_{\mathrm{vZD}}-$ fazinès vèlinimo trukmès vertè žemuosiuose dažniuose.

Bedispersiniai LI apibūdinami šiais pagrindiniais parametrais: pralaidumo juosta $\Delta F$, vèlinimo trukme, charakteringuoju impedansu ir perdavimo koeficientu. Kaip taisyklè šie parametrai matuojami arba skaičiuojami žemiausiuose dažniuose. Vietoje pralaidumo juostos pločio gali būti nurodoma pereinamosios charakteristikos užaugimo arba impulsinès charakteristikos trukmès.

Dispersinių LI DFCh keičiasi kintant dažniui, todèl tokiose įtaisuose fazinè vèlinimo trukmè nėra pastovi. Dispersiniai LI naudojami kai reikia pakeisti signalo formą pvz., moduliuoto dažnio radijo impulsams suspausti. Dispersiniai LI koreguoja dažninius fazès iškraipymus televiziniuose ir ryšio kanaluose. Jie naudojami signalų spektrų analizatoriuose, elektriškai valdomose vèlinimo sistemose, formuojant didelès amplitudès trumpus impulsus (Kabiri et al. 2011; Nikfal et al. 2011).

Svarbus etapas projektuojant elektroninius ịtaisus - jų sintezè. Pagal enciklopedinį apibūdinimą sintezè (graik. synthesis) - objekto elementu jungimas ị visumą. Elektroninių ịtaisų sintezè - elektronikos inžinerijos teorijos dalis, nagrinėjanti įtaisų, atitinkančių užsibrèžtus parametrus ir charakteristikas, projektavimo metodus.

Sintezės problemos ypač aktualios kuriant kompiuterizuotas sistemas mikrobangų įtaisams projektuoti. Pastaruoju dešimtmečiu daugelis tyrèjų visame pasaulyje sprendè šias problemas. Tarkime, (Rawat et al. 2009) darbe išvestos matematinès išraiškos, kurios apjungia projektuojamo įtaiso elektrines charakteristikas ir jo konstrukcinius parametrus. (Chiang et al. 2009) straipsnyje taikant komercinę programinę įrangą sudarytos nomogramos ir lentelès, siejančios įtaiso elektrines charakteristikas bei jo konstrukcinius parametrus. (Mikučionis, Urbanavičius 2010) darbe sukurta metodika sintezuoti keturių laidininkų daugialaidę mikrojuostelinę liniją (DML), veikiančią normaliujų bangų režimu. (Lee et al. 2009) straipsnyje išvestos matematinès išraiškos ir sudarytos nomogramos, leidžiančios nustatyti trijų laidininkų DML elektrines charakteristikas pagal ekvivalentines schemos parametrus.

Analizei ir sintezei vykdyti būtina turèti projektuojamo ịtaiso matematini modelị. Todèl meandrinei lètinimo sistemai tenka spręsti Maksvelo lygtis, ịvertinant konkrečias ribines sąlygas. Net paprasčiausių sistemų atveju tikslus ma- 
tematinis šių lygčių sprendimas neįmanomas, nes nėra tokios koordinačių sistemos, kurioje atsiskirtu kintamieji Maksvelo lygtyse. Todèl naudojami apytikriai analitiniai ir skaitiniai metodai, kuriuose buvo galima tiksliau ịvertinanti realius fizinius procesus nagrinejjamose sistemose.

Šiuo metu meandrinių sistemų analizèje dažniau taikomas daugialaidžių linijų metodas (Gao et al. 2009). Daugialaidès mikrojuostelinès linijos plačiai taikomos iqvairiuose elektroniniuose ịtaisuose signalams perduoti (Shufeng et al. 2003), transformuoti (Gupta et al. 2009), elektromagnetinèms bangoms spinduliuoti (Sakakibara et al. 2007) ir pan. Jų pagrindu taip pat kuriami mikrobangu įtaisu su periodinėmis struktūromis fiziniai ir matematiniai modeliai, pvz., perdavimo linijų (Park et al. 2005; Grasso et al. 2005), filtrų ir kryptinių šakotuvų (Masot et al. 1994), bei kreipimo ir lètinimo sistemų (Daškevičius et al. 2007).

Lètinimo sistemos modeliuojamos daugialaide linija, kuriose lygiagrečios laidininkų atkarpos yra statmenos modeliuojamos sistemos ašiai, o skerspjūvio matmenys ir konstrukcija sutampa su nagrinejjama sistema. Daugialaidès linijos laidininkų galai sujungiami taip, kad būtų modeliuojama meandrinis lètinimo įtaisas (Martavičius, Urbanavičius 1996). Daugialaidžių linijų metodas leidžia ịvertinti laidininko konstrukciją ir matmenys (Martavičius, Urbanavičius 1996). Skaičiuojant nagrinejjamos sistemos lètinimo koeficientą ir charakteringajji impedansą, reikia rasti modeliuojančios daugialaidès linijos ilgines talpas arba ilginius krūvius (Štaras et al. 1998).

\subsection{Skaitiniai elektromagnetizmo analizès metodai}

Anksčiau, kai kompiuterinès technikos ištekliai buvo riboti, modeliuojant ir analizuojant LI buvo plačiai taikomas konforminių pakeitimų metodas, kurio pagrindu galima išvesti inžineriniams skaičiavimams patogias formules linijų parametrams tiesiogiai skaičiuoti. Žinomi du konforminių pakeitimų būdai: Vilerio (H.A.Wheeler) ir Šnaiderio (M.V.Schneider). Vilerio konforminiuose pakeitimuose išvestos palyginus paprastos formulès (Wheeler 1964). Šnaiderio pakeitimai skaičiuojami per elipsinius integralus, todèl formulès daug sudètingesnès (Schneider 1972).

Konforminių pakeitimų metodais išvestos formulès yra tinkamos tam tikriems nagrinejjamos sistemos geometrinių matmenų ruožams $0,2 \leq W / h \leq 2$; $0,05 \leq S / h \leq 2$, be to nuokrypis siekia $3 \%$ (Gupta et al. 1981). Taikant skaitinius metodus galima gauti daug tikslesnius rezultatus, o taip pat analizuoti ịvairių matmenų ir nestandartinès geometrijos sistemas.

$\mathrm{XX}$ a. devintajame dešimtmetyje, išaugus skaičiavimo technikos resursams, paprastos ir sudètingos konstrukcijos elektrodinaminių sistemų analizei 
vis dažniau pradèta taikyti skaitinius metodus (Gurskas 1995; Urbanavičius et al. 2009, Sadiku 2009). Literatūros šaltinių analitinè apžvalga rodo, kad įvairiems elektromagnetizmo uždaviniams spręsti dažniausiai taikomi skaitiniai baigtinių elementų (BE), baigtinių skirtumų (BS) ir integralinių lygčių metodai. Pažymètina, kad skaičiavimai, naudojant skaitinius metodus gali trukti labai ilgai, pvz. (Ergul et al. 2011) darbe minima iki 17 valandų trukmès skaičiavimai esant vienam analizuojam dažnio taškui. Tačiau skaitinių metodų taikymas leidžia ịvertinti daugiau faktorių nei analitiniais metodais grịsti modeliai, t. y. paviršinị ir kraštu efektus laidininkuose, nuostolius dielektrikuose ir elektrodų laikikliuose, o tai leidžia gauti pakankamai tikslius rezultatus. Tokių modelių analizei nereikalingos sudètingos matematinès išraiškos, todèl LI analizei verta taikyti daugialaidžių linijų ir skaitinių metodų derinius, skaičiavimus vykdant lygiagrečiuoju būdu.

BS metodas pagristas analizuojamos srities padalinimu tinkleliu, sprendinius ieškant tinklelio mazguose. Taikant BS metodą, pavyksta rasti elektrinio lauko pasiskirstymą DML skerspjūvyje. (Štaras et al. 2010) monografijoje palyginti DML charakteringojo impedanso apskaičiavimo nuokrypiai taikant BS ir momentų metodus bei šių metodų efektyvumas analizuojant DML. Taikant BS metodą, sprendimo sẻkmei didelę ịtaką turi analizuojamos srities dydžio parinkimas. Pastaraisiais metais labai daug uždavinių, susijusių su elektromagnetinio lauko analize, yra sprendžiami baigtinių skirtumų laiko srityje (angl. finite difference time domain - FDTD) metodu.

Skaičiavimo BS metodu tikslumas priklauso nuo tinklelio mazgų skaičiaus analizuojamoje srityje - didinant mazgų skaičių mažejja potencialų apskaičiavimo paklaida. Tačiau didinant mazgų skaičių, gaunami didesni duomenų masyvai, ilgèja skaičiavimo trukmè, nes didèja iteracijų, garantuojančių pageidaujamą skaičiavimo tikslumą, skaičius (iteracijų skaičius proporcingas tinklelio mazgų skaičiaus kvadratui). Praktikoje skaičiavimo BS metodo tikslumą riboja skaičiavimo įrangos resursai ir tai, kad modelis gali nepilnai atitikti realią nagrinèjamą sistemą.

Siekiant nustatyti konforminių pakeitimų metodo taikymo galimybes mikrojuosteliniams LI modeliuoti, buvo atlikta susietųų mikrojuostelinių linijų (1.2 pav.) analizè. Analizuojant linijas buvo priimta, kad jos bus žadinamos lyginiu ir nelyginiu būdu ir bus keičiami jų konstrukciniai parametrai - mikrojuostelių plotis $W$, tarpas tarp mikrojuosteliu $S$, dielektriko pagrindo plotis $h$ ir skvarba $\varepsilon_{\mathrm{r}}$. Konforminių pakeitimų metodu grịsti skaičiavimai atlikti pagal (Gupta et al. 1981) metodiką, BS metodu grịstiems skaičiavimams pritaikyta autoriaus sukurta programinè ịranga. Pažymètina, kad BS metodu apskaičiuotos vertės buvo kontroliuojamos jas lyginant su momentų metodu gautomis vertemis. Mikrojuostelinių susietujų linijų analizès, atliktos konforminių pakeitimų ir BS metodais, rezultatai pateikti 1.3 ir 1.4 pav. 


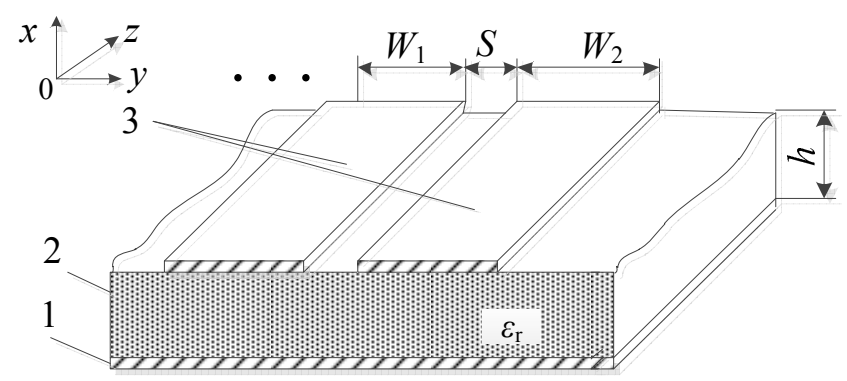

1.2 pav. Susietųjų mikrojuostelinių linijų konstrukcija:

1 - ekranas; 2 - dielektrinis pagrindas; 3 - mikrojuostelès

Fig. 1.2. Construction of the coupled microstrip line:

1 - conducting shield; 2 - dielectric substrate; 3 - microstrips

1.3 ir 1.4 pav. matyti, kad didinant mikrojuostelių plotị ir pagrindo dielektrinę skvarbą, charakteringasis impedansas mažèja, o santykinė efektyvioji dielektrinè skvarba didejja, esant lyginiam, ir nelyginiam mikrojuostelių sužadinimui. Didinant tarpą tarp mikrojuostelių esant lyginiam sužadinimui charakteringasis impedansas mažèja (1.3 pav., $a$ ir $b$ ), o nelyginiam sužadinimui turi didèti dèl mažèjusios abipusès ilginès talpos tarp mikrojuostelių. Tačiau, 1.3 pav., $c$ ir $d$ matyti, kad esant nelyginiam mikrojuostelių sužadinimui didèjant $S / h$, didejja tik impedansas, apskaičiuotas taikant BS metodą. Kai mikrojuostelès nèra plačios $(W / h=0,5)$, tarpą tarp jų didinant daugiau nei $S / h \geq 2$, charakteringasis impedansas apskaičiuotas, taikant konforminių pakeitimų metodą mažeja (1.3 pav., $c$ ir $d$ ) - tai prieštarauja fiziniams procesams susietose mikrojuostelèse.

Santykinės efektyviosios dielektrinės skvarbos pokyčiai, kintant konstrukciniams susietujų mikrojuostelinių linijų parametrams (1.4 pav.), sudètingesni nei atitinkami charakteringojo impedanso pokyčiai (1.3 pav.). Skirtumai tarp verčių gautų, taikant konforminių pakeitimų ir BS metodus, neviršija $3 \%$ tik esant pakankamai plačioms mikrojuostelèms $(W / h \geq 0,5)$ ir kai tarpas tarp jų nėra labai didelis $(S / h \leq 2)$. Pažymètina, kad skirtumas tarp nelyginiu budų sužadintų plonų ( $W / h=0,1)$ susietųju mikrojuostelių santykinės efektyviosios dielektrinès skvarbos verčių, gautų konforminių pakeitimų ir BS metodais viršija $35 \%$. Taigi, nepaisant konforminių pakeitimų metodu grịstų mikrojuostelinių linijų matematinių modelių efektyvumo, jų taikymas yra ribotas. 

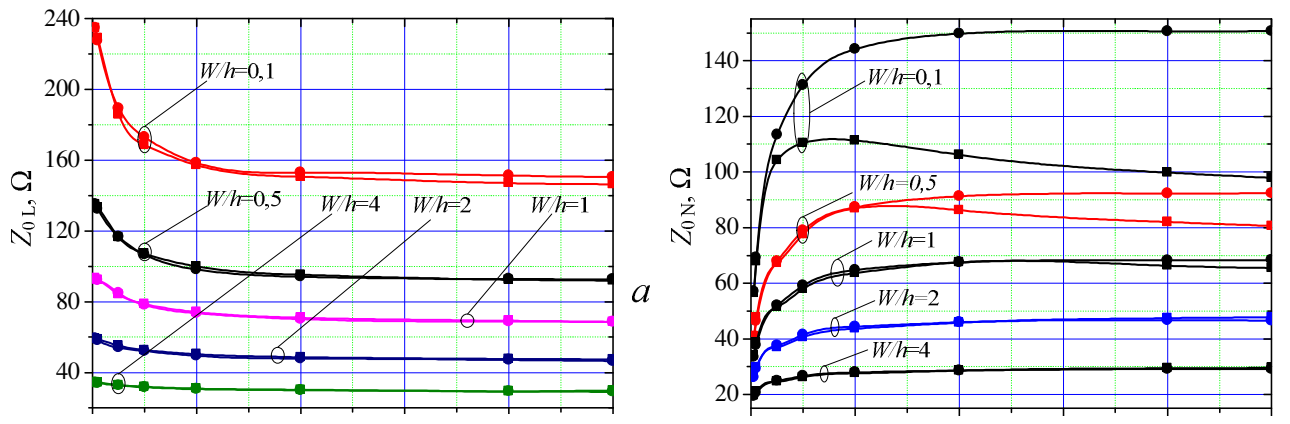

$c$
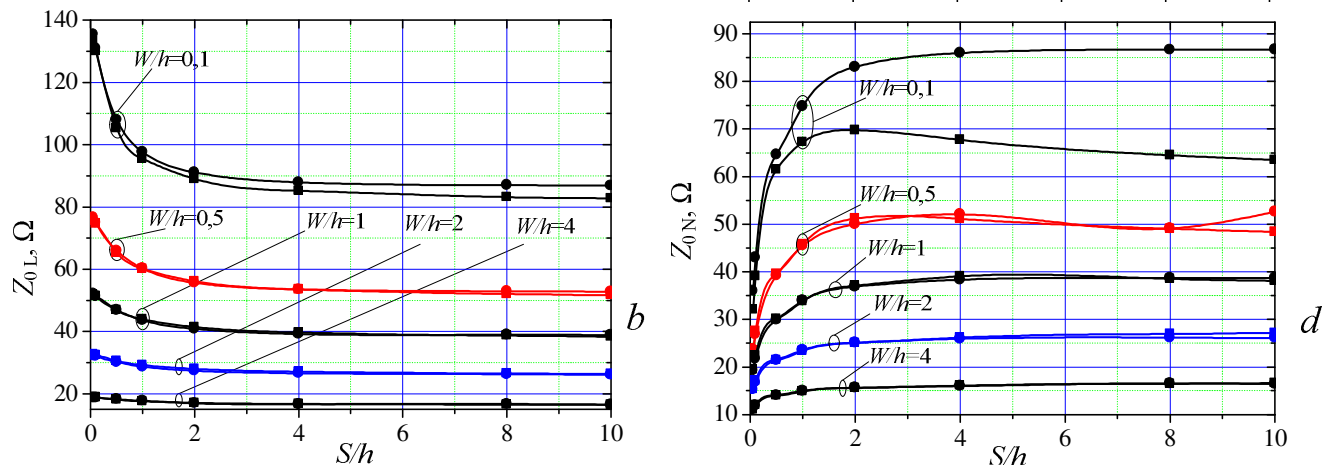

1.3 pav. Susietųų mikrojuostelinių linijų charakteringojo impedanso priklausomybès nuo linijos konstrukcinių parametrų (mikrojuostelių pločio - $W$, tarpo tarp mikrojuostelių - $S$ ir dielektrinio pagrindo storio - $h$ esant lyginiam $(a$ ir $b)$ ir nelyginiam ( $c$ ir $d$ ) sužadinimui. Čia apskritimais paženklintos kreivès, gautos taikant BS metodą, kvadratais - kreivès, gautos taikant konforminių pakeitimų metodą; pagrindo santykiné dielektrinè skvarba $\varepsilon_{\mathrm{r}}=4,7 \quad a$ ir $b$ grafikuose, $\varepsilon_{\mathrm{r}}=16,0 c$ ir $d$ grafikuose

Fig. 1.3 . Characterisctic impedanse of the microstrip coupled line versus line construction parameters (microstrip width $-W$, space between microstrips $-S$ and dielectric substrate thick $-h$ ) here circular marked finite difference method and rectangular marked - conformal transformation method, also $a$ and $b$ graphs represent even mode when $\varepsilon_{\mathrm{r}}=4.7$ and $\varepsilon_{\mathrm{r}}=16.0$ correspondantly, and $c$ and $d$ graphs represents odd mode when $\varepsilon_{\mathrm{r}}=4.7$ and $\varepsilon_{\mathrm{r}}=16.0$ correspondently 

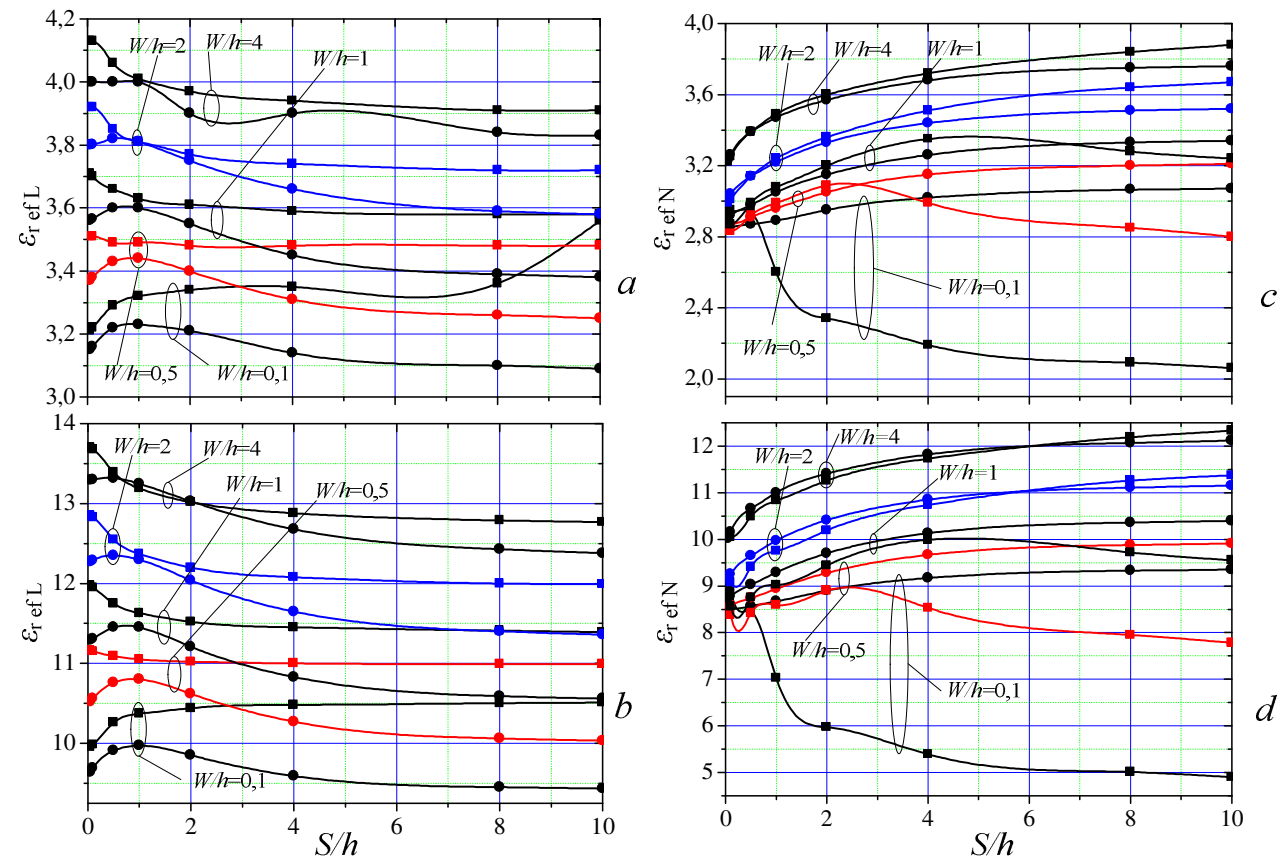

1.4 pav. Susietųjų mikrojuostelinių linijų santykinės efektyviosios dielektrinės skvarbos priklausomybės nuo linijos konstrukcinių parametrų (mikrojuostelių pločio - $W$, tarpo tarp mikrojuostelių - $S$ ir dielektrinio pagrindo storio - $h$ ) esant lyginiam $(a$ ir $b)$ ir nelyginiam ( $c$ ir $d$ ) sužadinimui. Čia apskritimais paženklintos kreivès, gautos taikant BS metodą, kvadratais - kreivès, gautos taikant konforminių pakeitimų metodą; pagrindo santykiné dielektrinè skvarba $\varepsilon_{\mathrm{r}}=4,7 \quad a$ ir $b$ grafikuose, $\varepsilon_{\mathrm{r}}=16,0 c$ ir $d$ grafikuose

Fig. 1.4. Effective dielectric permitivity of the microstrip coupled line versus line construction parameters (microstrip width $-W$, space between microstrips $-S$ and dielectric substrate thick $-h$ ) here circular marked finite difference method and rectangular marked - conformal transformation method, also $a$ and $b$ graphs represent normal mode when $\varepsilon_{\mathrm{r}}=4.7$ and $\varepsilon_{\mathrm{r}}=16.0$ correspondantly, and $c$ and $d$ graphs represents odd mode when $\varepsilon_{\mathrm{r}}=4.7$ and $\varepsilon_{\mathrm{r}}=16.0$ correspondently

Baigtinių elementų metodas pagrịstas analizuojamos srities sudalijimu elementais, kuriuose lauką apibūdinančio diferencialinio dydžio kitimo dèsnis keičiamas dažniausiai nesudėtinga interpoliacine funkcija (Sadiku 2009). Taikant baigtinių elementų metodą, labai svarbi analizuojamos srities sudalijimo elementais procedūra. Ją automatizuoti sunku, todèl uždavinio sprendimo sèkmę lemia 
skaičiuotojo patirtis ir inžinerinè intuicija. Taikant kvazi-TEM artinį, baigtinių elementų metodu analizuojamos ịvairių konstrukcijų elektrodinaminès sistemos (Davidovitz 2002; Xiao 2010). Teigiama (Sadiku 2009), kad baigtinių elementu metodas yra universalesnis, lyginant su BS metodu, tačiau reikalauja didesnių kompiuterinių resursų, be to, reikia daugiau darbo ruošiant pradinius duomenis ir programas.

Kitas skaitinis metodas taikomas elektrodinaminėms sistemoms analizuoti, - tai integralinių lygčių metodas (Sadiku 2009). Pagal ši metodą sprendiniai pateikiami integralinèmis lygtimis, kuriose nežinomieji įeina i pointegralines išraiškas. Nežinomiems srovių tankiams nustatyti integralinès lygtys dažnai sprendžiamos momentų metodu (integralinių lygčių metodas dar vadinamas momentų metodu) (Sadiku 2009). Šiuo metodu elektrodinamines LI nagrinejja (Gurskas et al. 2010; Urbanavičius et al. 2009) publikacijų autoriai.

Taikant skaitinius metodus, galima sukurti universalias, daugeliui lètinimo sistemų konstrukcijų tinkančias analizės metodikas ir pasiekti aukštą skaičiavimo tikslumą. Skaitiniai metodai padeda ištirti sudètingos konfigūracijos ar skerspjūvio sistemas, kur analitinius metodus taikyti komplikuota. Tačiau modeliuojant elektrodinaminius įtaisus skaitiniais metodais analizė gali trukti labai ilgai - nuo dešimčių minučių iki dešimčių valandų (Ergul et al. 2011; Gurskas 1995; Martavičius et al. 2001).

Programiniuose paketuose, kurie skirti elektrinių ir magnetinių laukų analizei, vienas pirmujų metodų $1970 \mathrm{~m}$. buvo pradètas naudoti momentų metodas (Ishii, Baba 2000). Kadangi jo igyvendinimas reikalauja mažai kompiuterių resursų ir buvo paprasčiausiai igyvendinamas tų metų skaičiavimo technika. (Skudutis et al. 2006) darbe taikomas CST Microwave Studio ${ }^{\circledR}$ programu paketas. Šis programų paketas turi naudotojo sąsają, galingus geometrinių modelių braižymo įrankius ir našų skaičiavimo branduolị, kuris leidžia gerokai sutrumpinti mikrobangų ịtaisų projektavimo trukmę. Čia taikomas baigtinių integralų metodas, kuris, îvertindamas energijos tvermès dèsni, iš pradžių aprašo Maksvelo erdvinio tinklelio lygtis, o po to formuoja specifines diferencialines lygtis (banginę arba Puasono). Metodas gali būti igyvendintas dažnių arba laiko srityse. Ittaiso skaidymo tinkleliui apribojimų nèra: greta ịprasto stačiakampio tinklelio Dekarto koordinačių sistemoje palaikomi ir nestačiakampiai tinkleliai, pvz., tetraedrinis. CST Microwave Studio ${ }^{\circledR}$ (CST 2011) pakete, bet kokios formos tūrinių struktūrų modeliavimui pagerinti, yra sukurtas originalus aproksimacijos būdas idealioms ribinèms sąlygoms (angl. perfect boundary approximation). Šis būdas leidžia modeliuoti bet kokios formos kreivinius paviršius. Išvengti laiptuoto priartejimo paklaidos, nereikalaudamas smulkiausio skaidymo tinklelio. Šis būdas taip pat leidžia ịvertinti metalinių sluoksnių arba mikrojuostelinių linijų storị papildomai nesuskaidytoje tinklelio skiltyje. Šio būdo galimybes išplètė plonų sienelių metodas (angl. thin sheet technique), leidžiantis optimaliai pateik- 
ti dvi kubinès tinklelio ląstelès dalis, atskirtas plona metaline sienele. Taigi, esant bet kokios formos elementams, galima gauti ypatingus sluoksnius su susmulkintu skaidymo tinkleliu.

Taip pat yra komercinè programinè ịranga labiau specializuota mikrojuostelinių ịtaisų projektavimui tame tarpe ir meandrinių mikrojuostelinių vélinimo liniju - Sonnet ${ }^{\circledR}$ (Sonnet 2011). Ši programinè ịranga grịsta hibridiniu momentų metodu kartu su greitaja Furjè transformacija. Ji leidžia valdyti analizuojamos srities tinklelio dydị, braižyti trimatị ịtaiso modeli, ịvertinti medžiagų storị ir kt. Kadangi šio programinio paketo bandomoji versija yra laisvai platinama, ji bus naudojama šiame darbe kaip alternatyva atliekant tyrimus ir lyginant apskaičiuotus rezultatus.

Bendruoju atveju, daugelis elektromagnetiniam modeliavimui skirtu programinių paketų yra mokami komerciniai programiniai paketai, t. y. Ansys (Ansys 2011), Argus (LAACG 2011), CST Microwave Studio, HFSS (HFSS 2011), IE3D (Mentor Graphics 2011), MAFIA (Mafia 2011), Microwave Office (AWR 2011), Semcad (Semcad 2011), ir kiti. Kai kurie programiniai paketai yra nemokami, tačiau jų galimybès žymiai mažesnès nei komercinių. Paminètini tokie nemokami programiniai paketai: Femlab (FEMLAB 2011), emGine (emGine 2011), Michelle (SAIC 2011).

\subsection{Naujos lygiagrečiụjų skaičiavimų kryptys}

Visai neseniai, superkompiuteriai buvo masyvios lygiagrečiosios skaičiavimo mašinos, užimančios didelius patalpų plotus (Robat 2007). Jie sudaryti iš atskirų skaičiavimo komponenčių - mazgu susidedančių iš procesoriaus, pagrindinès atminties ir ryšio posistemio. Kiekvienas procesorius disponuoja nuosava atmintimi, o ryšys tarp mazgų realizuojamas taikant pranešimų siuntimo technologiją (angl. message passing interface -MPI). Ryšys yra būtinas pranešimams tarp mazgų siųsti todèl jungiamasis tinklas yra lemiamas faktorius lygiagrečiujų skaičiavimo spartai užtikrinti. Be to atsiranda sinchronizacijos problemos tarp procesorinių mazgų. Esant tokioms problemoms nèra dar sukurta efektyvių priemonių automatiškai vykdyti lygiagretujji pradinị kodą. CRAY T3E kompiuteris - tai vienas iš tokių įrenginių, kurio architektūra yra vieno instrukciju srauto ir daugelio duomenu srautu (Vollaire et. al. 1998).

Minèta kompiuterių architektūrų klasifikacija, sukurta Flino (Flynn 1972) yra pripažinta ir dabar naudojama (Stallings 2009). Flinas pasiūlè tokias kompiuterių kategorijas:

- Vieno instrukcijų srauto ir vieno duomenų srauto architektūra (angl. single instruction single data - SISD). Vienas procesorius vykdo vieną 
instrukcijų srautą; operacijos atliekamos su vieningoje atmintyje esančiais duomenimis. Tai įprastas nuoseklusis duomenų apdorojimas.

- Vieno instrukcijų srauto ir daugelio duomenų srautų architektūra (angl. single instruction multiple data - SIMD). Kiekviena instrukcija vykdoma su daugeliu apdorojamų duomenų vienu metu. Kiekvienas apdorojamas elementas saugomas tam tikroje atminties ląstelèje, todèl, viena instrukcija vykdoma daugelio procesorių su visais duomenų masyvo elementais. Šią kategoriją atitinka vektoriniai ir matriciniai procesoriai.

- Daugelio instrukcijų srauto ir vieno duomenų srauto architektūra (angl. multiple instruction single data-MISD). Apdorojamų duomenų seka siunčiama procesorių visumai, kurių kiekvienas vykdo tam tikrą instrukcijų srautą. Tokios architektūros procesoriai taikomi klaidų paieškai atliekant operacijas.

- Daugelio instrukcijų srautų ir daugelio duomenų srautų architektūra (angl. multiple instructions multiple data - MIMD). Keli procesoriai vienu metu vykdo skirtingus instrukcijų srautus su skirtingais duomenu masyvais. Tai yra lygiagrečiosios kompiuterizuotos sistemos pavyzdys. Procesoriai pagal MIMD schemą turi būti bendrosios paskirties, kad galètų vykdyti visas, duomenų apdorojimui būtinas, instrukcijas.

Lygiagrečiąsias kompiuterizuotas sistemas, atitinkančias MIMD schemą, galima klasifikuoti atsižvelgus ị procesorių keitimosi duomenimis būdus (Solihin 2008). Procesoriui disponuojant nuosava atmintimi - kiekvienas apdorojimo mazgas yra atskiras kompiuteris. Šiuo atveju kompiuteriai keičiasi informacija, naudojant juos jungiančius specialius kanalus arba ryšio tinklus. Tokia lygiagrečiųų kompiuterių sandara (1.5 pav.) vadinama kompiuteriu telkiniais (angl. clusters). Jeigu procesoriai kolektyviai naudoja bendrą atmintį, jiems yra prieinamos ir programos, ir duomenys. Tokiu būdu procesoriai gali keistis informacija naudodami šią atmintị. Tokios lygiagrečios sistemos vadinamos daugelio procesoriu sistemos su kolektyviai naudojama atmintimi (angl. shared memory multiprocessor).

$\mathrm{XX}$ a. devintajame dešimtmetyje atsirado naujos architektūros superkompiuteriai. Jie sudaryti iš vadinamujų hiper mazgu (angl. hyper nodes). Kiekviename tokiame mazge buvo ịdiegtas nedidelis kiekis (2-4) vektorinių arba skaliariujų procesoriu su kolektyviai panaudojama atmintimi. Hiper mazgai buvo sujungti tarpusavyje labai didelès spartos ryšio tinklu. Duomenų apsikeitimas vykdomas besikreipiant $\mathfrak{i}$ to paties adreso atminties ląstelę. Naudojant tokią architektūrą galima nesunkiai igyvendinti daugelio programų darbo režimą. Jeigu pradinis kodas vykdomas daugiau nei viename hiper mazge, tuomet ryšys tarp jų igyvendinamas taikant pranešimų siuntimo bibliotekas. Tokio ịrenginio pavyzdys gali būti NEC SX-5 kompiuteris (Vollaire et. al. 1998). Jis sudarytas iš 4 hiper maz- 
gų, kur kiekvienas iš jų turi 16 vektoriniu procesorių su 128 GB kolektyvinès atminties. Superkompiuteriai pastoviai tobulinami ir kuriami nauji, todèl jie yra nuolat testuojami ir patys sparčiausi kompiuteriai patenka ị Top 500 sąrašą (Top 500 2011).

Tokios architektūros superkompiuteriai yra pernelyg brangūs elektrodinaminių įtaisų projektavimui, todèl skaičiavimų didelei spartai pasiekti yra taikomi kompiuteriu telkiniai. Telkinyje tik viename kompiuteryje - valdančiajame (angl. master) gali būti prijungti monitorius, klaviatūra, kietasis diskas ir kita periferinè įranga, tuo tarpu kiti - pavaldieji (angl. slaves) kompiuteriai gali būti be būtinos periferinès ịrangos. Kompiuterių telkiniuose dažniausiai naudojami du kompiuteriu ryšio tinklai. Vienas ryšio tinklas yra skirtas administravimui (palyginus mažos spartos), o antras - duomenų ir pranešimų tarp kompiuterių siuntimui (didelès spartos). İkrovos metu kiekvienas pavaldusis kompiuteris reikalauja iš valdančiojo savo IP adreso ir įkrauna operacinę sistemą ị operatyviają atmintį (Betti et al. 2009). Ryšys tarp mikroprocesorinių mazgų igyvendinamas taikant pranešimų siuntimo sąsają (PSS). Šiam kompiuterių telkiniui yra taikomas vieno proceso daugelio duomenų (angl. single procesor multiple data $S P M D$ ) lygiagrečiojo programavimo būdas. Pateiktas kompiuteriu telkinio modelis yra sudarytasiš asmeninių kompiuterių, kurie yra palyginus nebrangūs ir kuriuose taikytina nemokama programine ịranga.

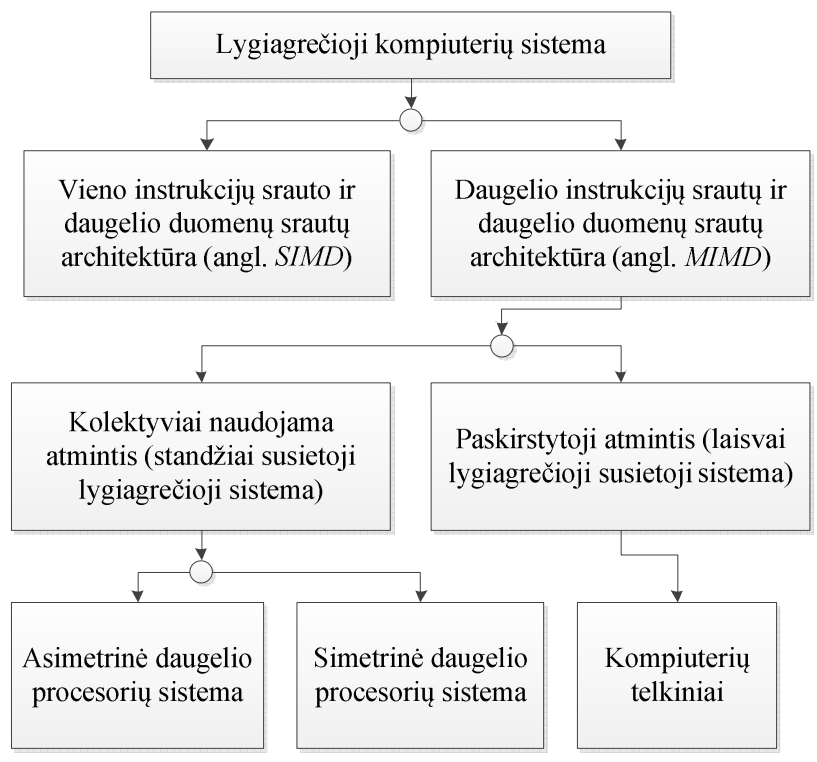

1.5 pav. Lygiagrečiųjų kompiuterių sistemų klasifikacija Fig 1.5. Classification of parallel processors architectures 


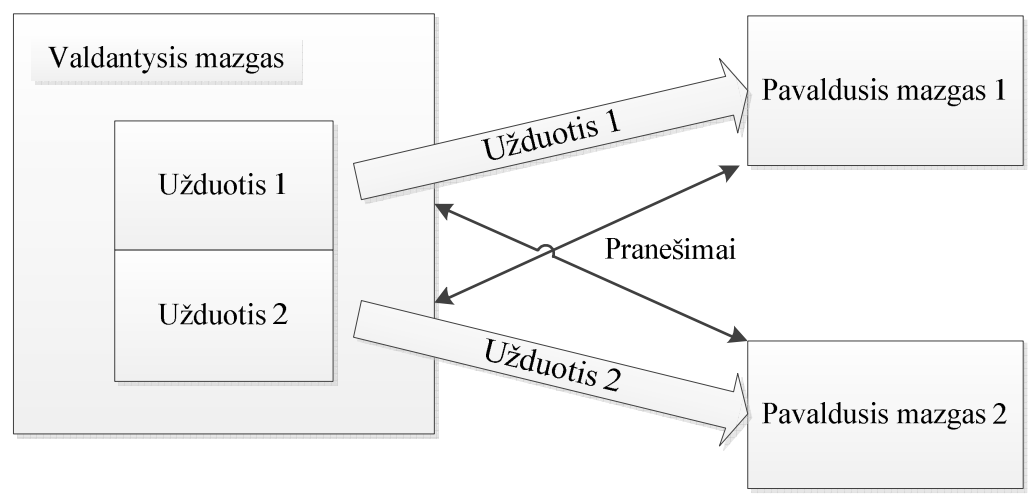

1.6 pav. Valdantysis-pavaldusis užduočių paskirstymo schema

Fig. 1.6. Master-slave task distribution scheme

Yra nemažai schemų sukurtų kompiuterių telkiniams ir lygiagretiems skaičiavimams realizuoti, bet žinomiausia yra vadinamoji „valdantysis - pavaldusis“ schema (Almeida et al. 2004), kuri pateikta 1.6. pav. Kuriant lygiagretuji programos algoritmą ir naudojant šią schemą programoje, nurodoma ką atliks valdantysis kompiuteris ir ką atliks pavaldusis kompiuteris. Dažniausiai valdantysis kompiuteris vykdo bendrus skaičiavimus ir padalina pradinius duomenis kiekvienam pavaldžiajam, bei surenka galutinius rezultatus ir išveda juos naudotojui. Visus lygiagrečiuosius skaičiavimus atlieka pavaldieji kompiuteriai.

Be superkompiuteriu ir kompiuterių telkinių, šiuo metu yra galimybė vykdyti lygiagrečiąsias programas ir viename asmeninime kompiuteryje. Tai įmanoma atlikti kompiuteryje su daugelio branduoliu mikroprocesoriumi, bendrosios paskirties grafikos apdorojimo itaisu ir kitais specialiosios paskirties įrenginiais pvz., lauku programuojamos loginès matricos (angl. field programmable gate array - FPGA).

Šiuo metu gaminamuose centriniuose procesoriu ịrenginiuose yra nuo 2 iki 16 branduoliu, pvz, Sun SME1832 (Oracle 2011), be to jie yra superskaliarios sandaros, t. y., kiekvienas branduolys gali atlikti dvi ir daugiau instrukcijas vienu metu (Sun SME1832 atlieka 8 instrukcijas vienu metu). Iprastuose kompiuteriuose naudojami Intel ${ }^{\circledR}$ arba $\mathrm{AMD}^{\circledR}$ firmų mikroprocesoriai, kurių instrukcijų rinkiniai praktiškai identiški, todèl leidžia naudotis panašiomis priemonèmis, kuriant lygiagrečiąsias programas. Yra dvi nemokamos programavimo bibliotekos $\mathrm{C}$ ir $\mathrm{C}++$ programavimo kalboms - PThreads ir OpenMP, kuriuose yra funkcijos, leidžiančios kreiptis ị bendrai naudojamas mikroprocesoriaus branduolių spartinančiąsias atmintis ir pateikti duomenis, instrukcijas kiekvienam branduoliui atskirai. Nepaisant to, kad daugelio branduolių mikroprocesorius pradèta diegti kompiuteriuose palyginus neseniai (Celeron 2011) elektromagne- 
tinių laukų skaičiavimams jie jau yra taikomi. Be to pastebèta, kad kelių branduoliu procesoriai taikomi ir kompiuterių telkiniuose (Seshima et al. 2006; Buchau el al. 2008; Sarkar et al. 2010).

Bendrosios paskirties grafikos apdorojimo įtaisai skirti vaizdo informacijos apdorojimui ir išvedimui ị monitorių, tačiau juos taip pat pradejjo taikyti lygiagrečiuose skaičiavimuose (Nvidia 2011, AMD 2011). Pagrindiniai šiu įtaisų gamintojai yra Nvidia $^{\circledR}$ ir AMD $^{\circledR}$. Šiuolaikiniai grafikos procesoriai gali turèti daugiau negu 128 branduolius, be to viename kompiuteryje galima jungti kelias grafikos plokštes ir tokiu būdu dar labiau padidinti bendrą branduoliu skaičiu, taikytinų lygiagrečiuose skaičiavimuose. Didžiausias grafikos apdorojimo ịtaisų privalumas - realiųjų skaičių apdorojimo aparatinėmis priemonėmis galimybė. Todèl jų sparta, sprendžiant užduotị suformuluota naudojant realius skaičius, yra žymiai didesné nei bendrosios paskirties mikroprocesorių. Išvardintos lygiagrečiojo skaičiavimo priemonès gali būti panaudotos kompleksiškai t. y. kompiuteriuose įdiegti daugelio branduolių bendrosios paskirties grafikos ịtaisai, daugelio branduolių mikroprocesoriai ir šie kompiuteriai sujungti tinklu ị didelio pajègumo kompiuteriu telkini (Hartley et al. 2008).

Tarp specialiosios paskirties įtaisų, taikytinų lygiagrečiuose skaičiavimuose galima paminèti lauku programuojamas logines matricas (Chen, Dinavahi 2009). Tai loginių blokų, kurie gali būti programiškai sujungti tarpusavyje visuma. Naujausiuose laukų programuojamose loginèse matricose loginių blokų gali būti iki 760000 (Xilinx 2011), kaip Xilinx Virtex-6 modelyje. Sujungiant atskirus blokus, galima realizuoti norimas duomenų apdorojimo funkcijas. Blokus galima sujungti taip, kad apdorojimo funkcijos būtų vykdomos lygiagrečiai. Šiems įtaisams programuoti dažniausiai naudojama VHDL programavimo technologija. Pagrindinis programuojamų matricų trūkumas yra didelè, net $20000 \mathrm{Lt}$ siekianti kaina (Lemona 2011), todèl jos nèra plačiai naudojamos.

\subsection{Lygiagrečiụjų sistemụ taikymas elektromagnetizmo uždaviniams spręsti}

Tiriant elektrodinaminius LI skaitiniais metodais tenka skaičiuoti elektrinio lauko potencialų arba krūvių pasiskirstymą analizuojamoje srityje. LI ieškomų elektrinių parametrų paklaida atitiks leistinus nuokrypius tik tuomet, kai analizuojamoje LI srityje gretimų apskaičiuojamų potencialų arba dalinių krūvių skirtumas bus keliomis eilèmis mažesnis negu leistini ieškomų parametrų nuokrypiai. Tai pasiekiama padalinus analizuojamą sriti mažo žingsnio tinkleliu ir potencialus arba krūvius apskaičiuojant tinklelio mazguose. Tankus analizuojamos srities tinklelis sąlygoja didelị kiekį nežinomụjų ir atitinkamai poreikị dide- 
lès apimties kompiuterinių išteklių (Esposito, Tarricone 2003; Jobava et al. 2004). Dideli kompiuterinių išteklių poreikiai tenkinami sudarant lygiagrečiąsias kompiuterines sistemas (Zhang et al. 2008; Oguni, Aasai 2008).

Svarbiausioji lygiagrečiosios sistemos dalis - lygiagretusis užduoties sprendimo algoritmas, kuris gali būti sukurtas dvejais būdais (Bal, Haines 1998):

1. Sprendžiamos užduoties lygiagretinimas t. y. užduoties sprendimo proceso padalinimas ị savistovius etapus ir jų vykdymas atskiruose lygiagrečios sistemos kompiuteriuose.

2. Apdorojamu duomenu lygiagretinimas t. y. kai apdorojamas duomenu masyvas padalinamas tarp lygiagrečiosios sistemos kompiuterių ir kiekviename iš jų atliekamos analogiškos procedūros su tam tikram kompiuteriui skirtais masyvo elementais.

Vienas iš populiariausių skaitinių metodų, taikomų elektromagnetizmo uždaviniams spręsti, yra momentų metodas (Harrington 1990). Taikant šị metodą, arba jo modifikacijas sukurta daug programinès ịrangos skirtos naudojimui, tame tarpe ir lygiagrečiose sistemose, pvz., Sonnet ${ }^{\circledR}$ (Sonnet 2011). Taikant momentų metodą (Jobava et al. 2004) darbe aprašytas būdas išspręsti lygčių sistemą:

$$
\boldsymbol{A} \cdot \boldsymbol{x}=\boldsymbol{b},
$$

čia $\boldsymbol{A}$ - koeficientų matrica, $\boldsymbol{b}$ - žinomi potencialai ir $\boldsymbol{x}$ - sistemos sprendinys. Šiam tikslui igyvendinti autoriai papildomai pasinaudojo jau sukurtomis lygiagrečių skaičiavimų bibliotekomis (Bogdanov 2003) ir atliko matricos $\boldsymbol{A}$ išskaidymą blokais tarp kompiuteriu (1.7 pav.). (Zhang et al. 2010) darbe hibridinis momentų metodas taikomas antenu modeliavimui. Autoriai taip pat igyvendina matricos išskaidymą tarp kompiuterių jų resursams panaudoti. Abejuose paminètuose darbuose nèra konkretinamas modeliuojamas įtaisas, tačiau aptariami daugelio ịtaisu modeliavimo momentu metodu principai.

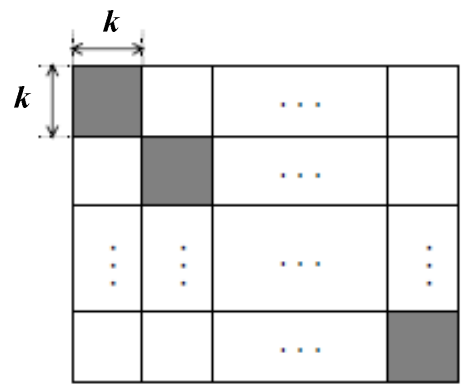

\begin{tabular}{|c|c|c|c|c|c|}
\hline Pr.0 & Pr.2 & Pr.0 & . . & Pr.0 & Pr. 2 \\
\hline Pr.1 & Pr. 3 & Pr.1 & . & Pr.1 & Pr. 3 \\
\hline Pr. 0 & Pr. 2 & Pr. 0 & . . & Pr. 0 & Pr. 2 \\
\hline . & & & &. & $\dot{.}$ \\
\hline Pr.0 & Pr.2 & Pr.0 & . . & Pr. 0 & Pr. 2 \\
\hline Pr.1 & Pr.3 & Pr.1 & & Pr.1 & Pr. 3 \\
\hline
\end{tabular}

1.7 pav. Matricos išskaidymas, čia $k$ - skaidymo bloko dydis ir eilučių bei stulpelių paskirstymas (Jobava et al. 2004)

Fig. 1.7. Matrix decomposition in block-cyclic sheme, where $k$ is the block size (Jobava et al. 2004) 
Matricos apdorojimo trukmè tiesioginių skaičiavimų atveju

$$
t=\frac{8}{3} \cdot \frac{n^{3}}{f}
$$

čia $t$ - matricos apdorojimo trukmè sekundėmis, $n$ - tiesinių lygčių sistemos nežinomųjų skaičius, $f$ - centrinio procesorinio įrenginio taktinis dažnis, Hz.

(Chen et al. 2007) darbe pateikiamas lygiagretusis baigtinių skirtumų laiko srities algoritmas, kuriame išskaidžius nagrinėjamą sritị kiekvienam lygiagrečiosios sistemos kompiuteriui, apskaičiuoti kraštiniai srities rezultatai gaunami iš pavaldžiujų kompiuterių tiesiogiai, nenaudojant valdančiojo kompiuterio. Pagal ši algoritmą skaičiavimai atliekami iteraciškai kiekvienam analizuojamos srities kubo elementui apskaičiuoti. Todèl po kiekvienos iteracijos elementu reikšmes reikia atnaujinti. Tai yra labai neefektyvu ir reikalauja didelių laiko sąnaudų keitimuisi duomenimis.

Iš iteracinių tiesinių lygčių sistemos sprendimo metodų paminètini kvaziminimaliosios liekanos (angl. quasi-minimal residual) metodas ir bi-jungtinio gradiento stabilizavimo (BiJGSTAB) metodas (angl. BI-Conjugate gradient stabilized), kurie palyginami (Iwashita et. al. 2000) straipsnyje dvimatės geometriškai simetrinių magnetinių ir elektrinių laukų skaičiavimams integriniuose grandynuose su magnetinių plèvelių elementais. Abu sprendimo būdai taikomi sukurtos tiesinių lygčiu sistemos paskirstymui tarp lygiagrečiosios sistemos skaičiavimo mazgų. Paskirstymo schema gaunama, taikant daugelio lygiu paskirstymo algoritmą (angl. family of multilevel partitioning slgorithms - METIS) (Karypis et. al. 1995). 1.2 lenteleje pateikti (Iwashita et. al. 2000) darbe bandytų tiesinių lygčių apskaičiavimo trukmès rezultatai, gauti skirtingais iteraciniais metodais.

1.2 lentelè. Matricos skaičiavimo trukmè su 48 procesoriais (Iwashita et. al. 2000). Skaičiuojama naudojant NEC Cenju-4 kompiuteri

Table 1.2. Matrice solving speed up with 48 processes (Iwashita et al. 2000). For calculations used NEC cenju-4 computer

\begin{tabular}{|l|c|}
\hline Sprendimo metodas & Skaičiavimų trukmė, $\mathbf{s}$ \\
\hline Sąlyginis BIJGSTAB & 14,4 \\
\hline BIJGSTAB su plečiamają įstrižaine & 22,9 \\
\hline Plečiamoji ịstrižainė & 31,9 \\
\hline
\end{tabular}


Tiesioginiai metodai leidžia rasti norimą sprendini nevykdant iteracijų, o sudarant ir sprendžiant tiesinių lygčių sistemą. Iteraciniai metodai nėra tinkami kuriant lygiagrečiąsias sistemas pagal duomenų lygiagretinimo būdą, kadangi kiekvienoje iteracijoje būtina atnaujinti apskaičiuotus duomenys tarp atskiru skaičiavimo įrenginių. Užduoties lygiagretinimo atveju turi būti taikomi tiesioginių skaičiavimų metodai. Tarkime, žemesniosios ir aukštesniosios trikampès matricos išskaidymas (angl. lower and upper matrix decomposition) pagal užduoties lygiagretinimo būdą nagrinejjamas (Sheng et. al. 2001) straipsnyje. Šiuo atveju lygiagrečioji kompiuterinè sistema naudojama trimačių mikrojuostelinių linijų trūkiui analizuoti. Lygiagrečiojo algoritmo vykdymo trukmės grafikas pateiktas 1.8 pav.

Jeigu uždavinys suformuluotas dalinių išvestinių lygtimis - lygiagrečiajam skaičiavimo algoritmui sudaryti taikytinas analizuojamos srities padalinimo ị dalines sritis principas (angl. a decomposition of the spatial domain of the problem into subdomains). Visi analizès metodai, grịsti padalinimu ị dalines sritis, gali būti klasifikuojami kaip padalinimas $i ̣$ iš dalies sutampančias sritis arba $p a-$ dalinimas $i$ nesutampančias sritis. Skaičiavimams atlikti šiuo atveju taikytini ir tiesioginiai, ir iteraciniai būdai. Siekiant užtikrinti lygiagrečiojo analizès algoritmo tinkamumą bet kokiam dalinių sričių skaičiui, privaloma yra sričių globaliojo sujungimo sąlyga (Adams 2008).

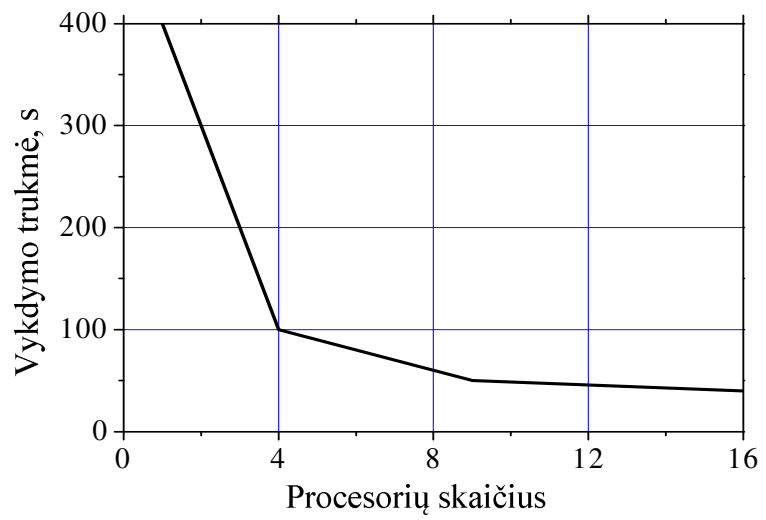

1.8 pav. Matricos skaidymas trimatės mikrojuostelinès linijos trūkių skaičiavimams (Sheng et. al. 2001)

Fig. 1.8. LU decomposition for 3D microstrip line break calculations (Sheng et. al. 2001) 
Metodams, atitinkantiems iš dalies sutampančių sričiu kategoriją, igyvendinti gali būti vykdoma vadinamoji Shwartz iteracija (Navsariwala et al. 1997). Minètame darbe teigiama, kad daugybės operacijų trukmè , atliekant Scwartz iteraciją, yra itin maža ir siekia vos 130 s esant 32 dalinėms sritims. Shwartz iteracijos šiuo atveju vykdomos, atliekant skaičiavimus pagal baigtinių elementų metodo modifikaciją - baigtinių elementų ardimo ir sujungimų metodą (angl. finite element tearing and interconnect - FETI).

Lygiagretiems algoritmams, grịstiems nesutampančių dalinių sričių būdais, sudaryti, naudojamas Schur metodas (Ergul et al. 2011), pagal kuri padalintos matricos srities kraštai, atitinkantys dviejų gretimų sričių sąsają yra papildomi naujomis apskaičiuotomis vertemis iš prieš tai apskaičiuotos iteracijos. Sudaryta tiesinių lygčių sistema sprendžiama taikant jungtiniu gradientu metoda arba apibendrinta minimaliu liekanu metoda (angl. generalized minimal residual method - GMRES).

\subsection{Apibendrinimas. Uždavinių formulavimas}

Apžvelgus elektrodinaminių lètinimo ịtaisų (LI) analizès ir sintezès metodus galima teigti, kad:

1. Daugialaidès mikrojuostelinès linijos (DML) ir meandrinès mikrojuostelinès vélinimo linijos (MMVL) plačiai taikomos ịvairios paskirties mikrobangų įtaisuose.

2. Elektrodinaminių LI tyrimas prasidejjo prieš 60 metų ir iki šiol vystosi kuriant naujus analizès ir sintezès būdus.

3. Taikant skaitinius elektromagnetizmo metodus, galima sumažinti LI analizès paklaidas ir kurti naujų konstrukcijų LI matematinius modelius.

4. Efektyvus skaitinių metodų taikymas reikalauja didelès apimties skaičiavimo išteklių, kuriuos realizuoti galima sudarant lygiagrečiasias kompiuterines sistemas.

5. Iki šiol, dèl komplikuoto analizès ir sintezès procesų paskirstymo tarp skaičiavimo mazgų, nėra sukurtų lygiagrečiujų elektrodinaminių LI tyrimo metodikų.

Siekiant sumažinti elektrodinaminių LI projektavimo trukmę ir paklaidas, reikia išspręsti šiuos uždavinius:

1.Pasiūlyti DML modelius, grịstus skaitiniais elektromagnetizmo metodais, tinkamus baigtinio dydžio MMVL analizei.

2. Sukurti ir ištirti lygiagrečiąsias DML analizès ir sintezès metodikas.

3. Sukurti ir ištirti lygiagrečiąją MMVL dispersinès charakteristikos apskaičiavimo metodiką.

4. Sukurti ir ištirti lygiagrečiają MMVL sintezès metodiką. 



\section{Daugialaidžių mikrojuostelinių linijụ modeliai}

Šiame skyriuje siūlomi du daugialaidès mikrojuostelinès linijos (DML) modeliai nevienalytėje terpeje. Pirmas modelis, grịstas baigtinių skirtumų (BS) metodu, leidžia apskaičiuoti potencialų pasiskirstymą DML skerspjūvyje ir pagal tai nustatyti kiekvieno laidininko ilginị krūvị ir kitus DML elektrinius parametrus. Antras modelis, grịstas momentų metodu, suteikia galimybę pagal nurodytus laidininkų potencialus iškart apskaičiuoti ilginio krūvio pasiskirstymą DML skerspjūvyje išsprendus sudarytają tiesinių lygčių sistemą.

Skyrių sudaro trys poskyriai ir išvados. Poskyryje 2.1 pristatyti du DML modeliai. 2.2 poskyryje tikrinamas modelių adekvatumas. Poskyriuose 2.3 ir 2.4 pateikiami atitinkamai modelių tyrimo rezultatai ir išvados.

Skyriaus tematika paskelbtas vienas autoriaus straipsnis (Urbanavičius, Pomarnacki 2008).

\subsection{Daugialaidžių mikrojuostelinių linijų modeliai}

Daugialaidès mikrojuostelinès linijos ir daugialaidès daugiasluoksnès juostelinès linijos yra plačiai taikomos daugelyje įvairių mikrobangų integri- 
niuose įtaisuose kaip signalų perdavimo linijos, filtrai ir kryptiniai šakotuvai, kreipimo ir vèlinimo sistemos.

DML konstrukcijos brèžinys pateiktas 2.1 pav. Tokios linijos terpè skersiniame pjūvyje (2.1 pav. $x 0 y$ plokštuma) yra nevienalytė - signaliniai laidininkai formuojami dielektrinio pagrindo paviršiuje, o virš jų yra oras.

Kuriant mikrobangų ịtaisus turi būti žinomi du pagrindiniai DML parametrai: mikrojuostelių charakteringieji impedansai ir bangos sklidimo greitis ties mikrojuostelëmis (Weiss, Bryant 1969). Bendruoju atveju charakteringasis impedansas apibūdinamas kaip santykis plokščios elektromagnetinès bangos elektrinio ir magnetinio laukų stiprio amplitudžių

$$
Z_{0}=\frac{E}{H},
$$

turintis elektrinės varžos dimensiją. Mikrojuostelinių linijų atveju charakteringasis impedansas gali būti apibūdinamas kaip įtampos ir srovès amplitudžių mikrojuostelëje santykis

$$
Z_{0}=\frac{U}{I}
$$

Elektromagnetinès bangos sklidimo greitis neribotojo terpejje, apibūdinamoje dielektrine skvarba $\varepsilon$ ir magnetine skvarba $\mu$ nustatomas pagal tokią formulę:

$$
v_{\mathrm{f}}=\frac{1}{\sqrt{\varepsilon \mu}} .
$$

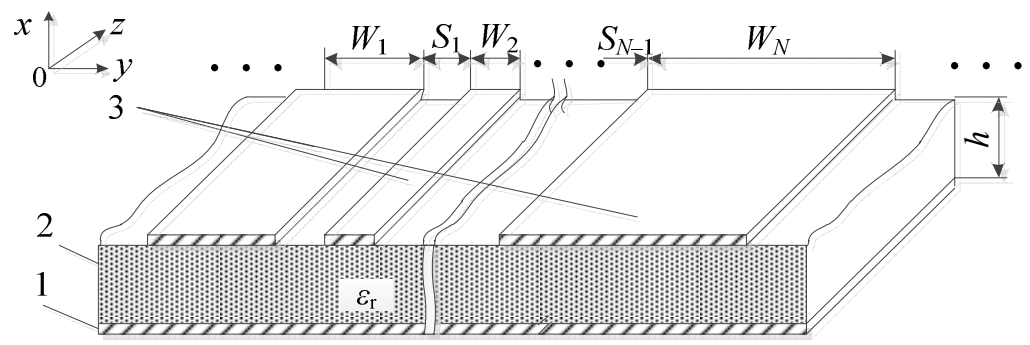

2.1 pav. Daugialaidès mikrojuostelinės linijos konstrukcija: 1 - ekranas; 2 - dielektrinis pagrindas; 3 - mikrojuostelès

Fig. 2.1. Construction of the microstrip multiconductor line: 1 - conducting shield; 2 - dielectric substrate; 3 - micostrips 
Bangos fazinis greitis mikrojuostelinèje linijoje yra mažesnis negu vakuume ir, kuomet linijos pagrindo santykinè magnetine skvarba $\mu_{\mathrm{r}}=1$, nustatomas pagal tokią formulę:

$$
v_{\mathrm{f}}=\frac{c_{0}}{\sqrt{\varepsilon_{\mathrm{ref}}}},
$$

čia $c_{0}=299792458 \mathrm{~m} / \mathrm{s}$ - elektromagnetinès bangos sklidimo vakuume fazinis greitis; $\varepsilon_{\text {ref }}-$ mikrojuostelinės linijos santykinè efektinė dielektrinė skvarba, apibūdinanti terpès nevienalytiškumą sąsajoje pagrindas-oras. Kai modeliuojamos DML darbinis dažnis yra pakankamai žemas arba DML dielektrinio pagrindo storis yra mažesnis už siunčiamos bangos ilgị, DML charakteringasis impedansas ir bangos fazinis greitis gali būti gauti analizuojant DML kvazi TEM artiniu žinant jos mikrojuostelių ilgines talpas ir induktyvumus (Boutboul et al. 1998)

$$
Z_{0 i}=\sqrt{\frac{L_{i}}{C_{i}}}=\frac{1}{c_{0}} \frac{1}{\sqrt{C_{i} C_{i}^{(\mathrm{a})}}}, v_{\mathrm{f} i}=c_{0} \cdot \sqrt{\frac{C_{i}^{(\mathrm{a})}}{C_{i}}},
$$

čia $Z_{0 i}-i$-osios mikrojuostelès charakteringasis impedansas; $v_{\mathrm{f} i}$ - elektromagnetinès bangos sklidimo greitis ties $i$-ają mikrojuostele; $L_{i}$ ir $C_{i}-i$-osios mikrojuostelès atitinkamai ilginiai induktyvumas ir talpa; $C_{i}^{(\mathrm{a})}-i$-osios mikrojuostelès ilginè talpa kai dielektrinis pagrindas DML pakeičiamas oru.

Bendruoju atveju sistemos charakteristikos, sudarytos iš $N$ susietujų mikrojuostelių esant normaliosioms bangoms, apibūdinamos $N$ elektromagnetinių bangu sklidimo konstantomis ir $N^{2}$ charakteringaisiais impedansais (Paul 2008). $N$ mikrojuostelių perdavimo linijos, veikiančios normaliujų bangų reži$\mathrm{mu}$, pagrindinès lygtys yra apibendrintosios telegrafinès lygtys (Paul 2008):

$$
\begin{gathered}
-\frac{\mathrm{d} \boldsymbol{U}}{\mathrm{d} z}=\boldsymbol{Z}_{\mathbf{0}} \times \boldsymbol{I}, \\
\boldsymbol{U}^{T}=\left[U_{1}, U_{2}, \ldots, U_{N}\right], \quad \boldsymbol{I}^{T}=\left[I_{1}, I_{2}, \ldots, I_{N}\right], \\
Z_{0 i j}=Z_{0 j i}=\sqrt{L_{i j} / C_{i j}}, \quad Y_{0 i j}=Y_{0 j i}=\sqrt{C_{i j} / L_{i j}},
\end{gathered}
$$


čia $U$ ir $I$ - ịtampų ir srovių mikrojuostelèse vektoriai, $z$ - išilginè daugialaidès linijos koordinate, $\boldsymbol{Z}_{0}$ ir $\boldsymbol{Y}_{0}--\frac{\mathrm{d} \boldsymbol{I}}{\mathrm{d} z}=\boldsymbol{Y}_{\mathbf{0}} \times \boldsymbol{U}$ daugialaidès linijos charakteringụjų impedansų ir banginių laidžių matricos, $L_{i i}$ ir $C_{i i}-i$-osios mikrojuostelès savasis ilginis induktyvumas ir talpa, $L_{i j}$ ir $C_{i j}-i$-osios ir $j$-osios mikrojuosteliu abipusiai ilginiai induktyvumai ir talpos $(i \neq j)$. Pažymètina, kad daugeliu praktinių atvejų bei tada, kai daugialaidès linijos pagrindu sudaromas lètinimo įtaiso modelis, pakanka nagrinèti ne grynujų normaliujų bangų darbo režimą, o jų superpoziciją, kai linija sužadinama lyginiu ir nelyginiu būdu, t. y. i mikrojuosteles siunčiant tos pačios amplitudès ir to paties arba priešingo ženklo ịtampas. Siekiant gauti tikslesnes daugialaidès linijos charakteristikas, ilginių talpų $C_{i i}$ ir $C_{i j}$ skaičiavimų neapibrèžtys turi būti minimalios.

Pirmas siūlomas DML modelis, leidžiantis apskaičiuoti minètas talpas, grịstas BS metodu (Zingg 1997). Programinès įrangos algoritmas, kuris įgyvendina šị DML modelị, pateiktas 2.2 pav. Algoritmą sudaro 10 žingsnių:

1. Itvedami analizuojamos DML parametrai: $N$ - mikrojuostelių skaičius; $\varepsilon_{\mathrm{r}}$ - dielektrinio pagrindo santykinè dielektrinè skvarba; $h$ - dielektrinio pagrindo storis; $\boldsymbol{W}$ - mikrojuosteliu pločių vektorius; $\boldsymbol{S}$ - tarpu tarp mikrojuostelių vektorius; $\boldsymbol{U}$ - mikrojuostelių įtampų vektorius; $\boldsymbol{A} \times \boldsymbol{B}-$ analizuojamos srities dydis; $\delta$ - leistinas skaičiavimo nuokrypis.

2. Sudaroma $\boldsymbol{A} \times \boldsymbol{B}$ dydžio nulių matrica.

3. Atsižvelgiant $\mathfrak{i}$ analizuojamos srities matricos vertikaliają simetriją ir dielektrinio pagrindo storị $h$, tam tikriems matricos elementams priskiriamos vertès, atitinkančios DML mikrojuostelių potencialus.

4. Taikant BS metodą DML skerspjūvyje skaičiuojamas potencialų pasiskirstymas (Zingg 1997).

5. Apskaičiuotų potencialų vertès lyginamos su ankstesnèje iteracijoje gautomis vertemis. Jeigu santykinis jų skirtumas $\delta^{\prime}$ mažesnis už leistiną skaičiavimo nuokrypi $\delta$ pereinama ties 6 žingsniu. Priešingu atveju, naudojant apskaičiuotas potencialų vertes, skaičiuojamos naujos potencialų vertès

6. Tikrinama ar potencialų skaičiavimai atliekami esant analizuojamoje srityje skirtingiems dielektrikams (dielektrinis pagrindas ir oras virš jo) ar dielektrikas yra vienalytis; pirmuoju atveju būtina atkreipti dèmesị ị sąsają tarp dielektrikų, kuri turi būti apskaičiuojama specifiniu būdu (Urbanavičius, Pomarnacki 2008). 


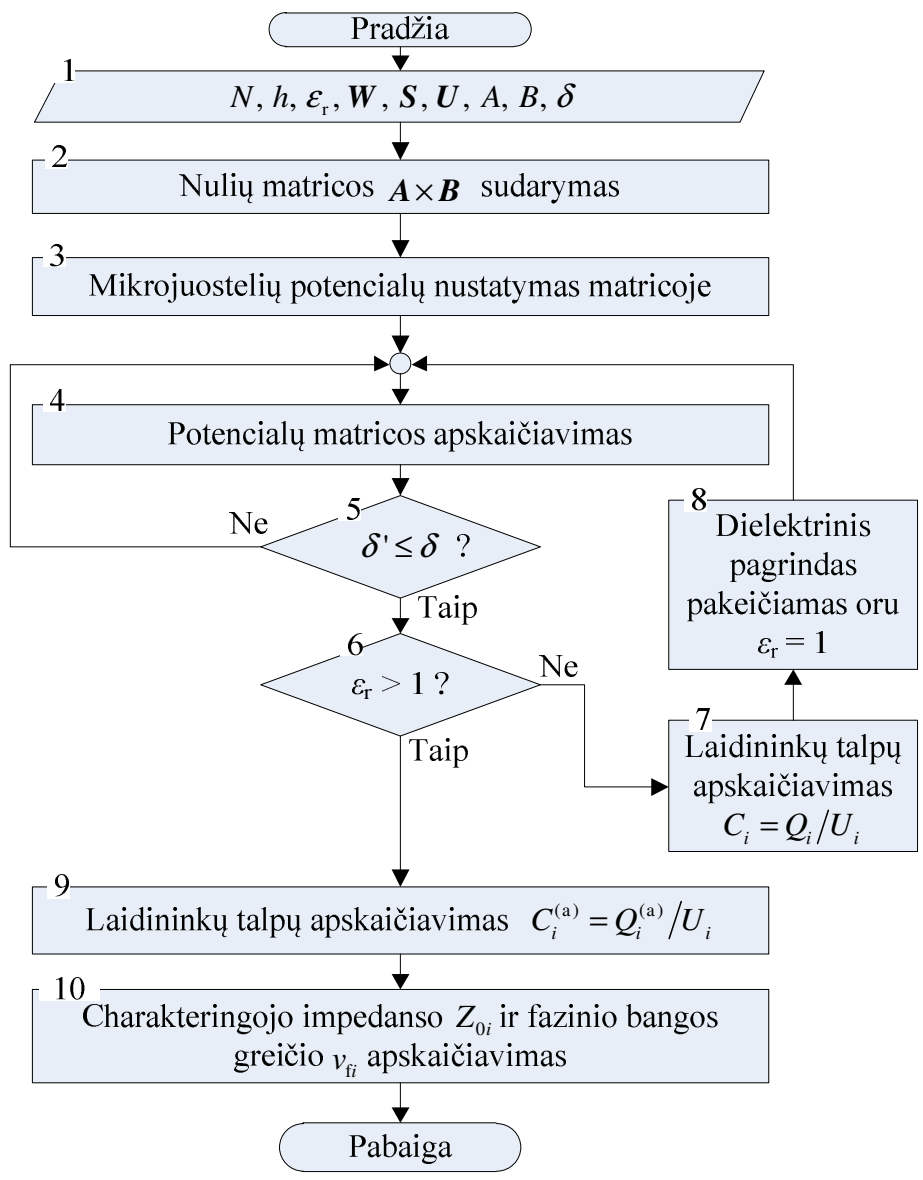

2.2. pav. Daugialaidès mikrojuostelinès linijos modelio, grịsto baigtinių skirtumų metodu, supaprastintas algoritmas

Fig. 2.2. The simplified algorithm of the microstrip multiconductor line model based on finite difference method

7. Kuriamas menamas stačiakampis kontūras aplink kiekvieną mikrojuostelę ir kiekvienos iš jų skaičiuojama ilginè talpa naudojant menamo kontūro viduje sukauptus krūvius.

8. DML dielektrinis pagrindas pakeičiamas oru ir kartojami 5 ir 6 žingsniai.

9. Šis žingsnis identiškas 7 žingsniui, skirtumas yra tik tas, kad apskaičiuojama kiekvienos DML mikrojuostelès talpa $C_{i}^{(\mathrm{a})}$, kai $\varepsilon_{\mathrm{r}}=1$.

10. Pagal (2.5) lygtis apskaičiuojami kiekvienos mikrojuostelès charakteringasis impedansas ir bangos sklidimo greitis. 
Antras siūlomas DML modelis sukurtas taikant momentų metodą (Harrington 1990). Daugialaidès mikrojuostelinès linijos charakteringojo impedanso skaičiavimo metodikos pagrindinès idejos išnagrinètos aukščiau, todėl dabar aptarsime tik daugialaidès linijos parametrų apskaičiavimo algoritmą, grịstą momentų metodu. Pagal 2.3 pav. pateiktą blokinę schemą tokį algoritmą sudaro 10 žingsnių:

1. Nurodomi analizuojamosios daugialaidès mikrojuostelinès linijos konstrukciniai parametrai: dielektrinio pagrindo storis $h$ ir santykine dielektrinè skvarba $\varepsilon_{\mathrm{r}}$; mikrojuostelių linijoje skaičius $N$, mikrojuostelių pločių vektorius $\boldsymbol{W}$ ir tarpų tarp jų vektorius $S$; ị mikrojuosteles siunčiamų įtampų vektorius $\boldsymbol{U}$.

2. Kiekviena mikrojuostelè dalinama ị vienodo pločio $M_{n}$ dalines sritis; čia $n$ - mikrojuostelès eilès numeris.

3. Kuriama $M=\sum_{n} M_{n}$ dydžio tiesinių lygčių sistema matricine forma $\boldsymbol{U}=\boldsymbol{G} \times \boldsymbol{q}$. Esminė operacija šiuo atveju - Gryno funkcijos, kiekvienai iš $M$ dalinių sričių, išvedimas. Gryno funkcijų išvedimo metodika išsamiai pateikta (Urbanavičius et al. 2007) darbe.

4. Sprendžiama tiesinių lygčių sistema, pvz., apskaičiuojant atvirkštinę Gryno funkcijų matricą ir nustatomi nežinomi krūviai kiekvienoje iš $M$ dalinių sričių.

5. Sumuojant dalinių sričių krūvius $q_{i}$ atitinkamų mikrojuostelių ribose, gaunami pilnieji šių mikrojuostelių krūviai ilginiai $\boldsymbol{Q}$.

6. Tikrinamas tiesinių lygčių sistemos sprendimas. Jei dielektrinio pagrindo ịtaka buvo ịvertinta (pirmasis lygčių sistemos sprendimo atvejis) - pereinama prie 7 žingsnio. Jei dielektrinio pagrindo nepaisyta (daugialaidès linijos terpé tapo homogeninè, $\varepsilon_{\mathrm{r}}=1$ ) - pereinama prie 9 žingsnio.

7. Apskaičiuojama kiekvienos mikrojuostelès ilginè talpa $C_{i}=Q_{i} / U_{i}$.

8. Iš daugialaidès mikrojuostelinès linijos pašalinus dielektrini pagrindą (pagrindo dielektrinè skvarba prilyginama vienetui: $\varepsilon_{\mathrm{r}}=1$ ), linijos terpé pasidaro homogeninė ir 3 žingsniu sudaryta tiesinių lygčių sistema sprendžiama dar kartą. 


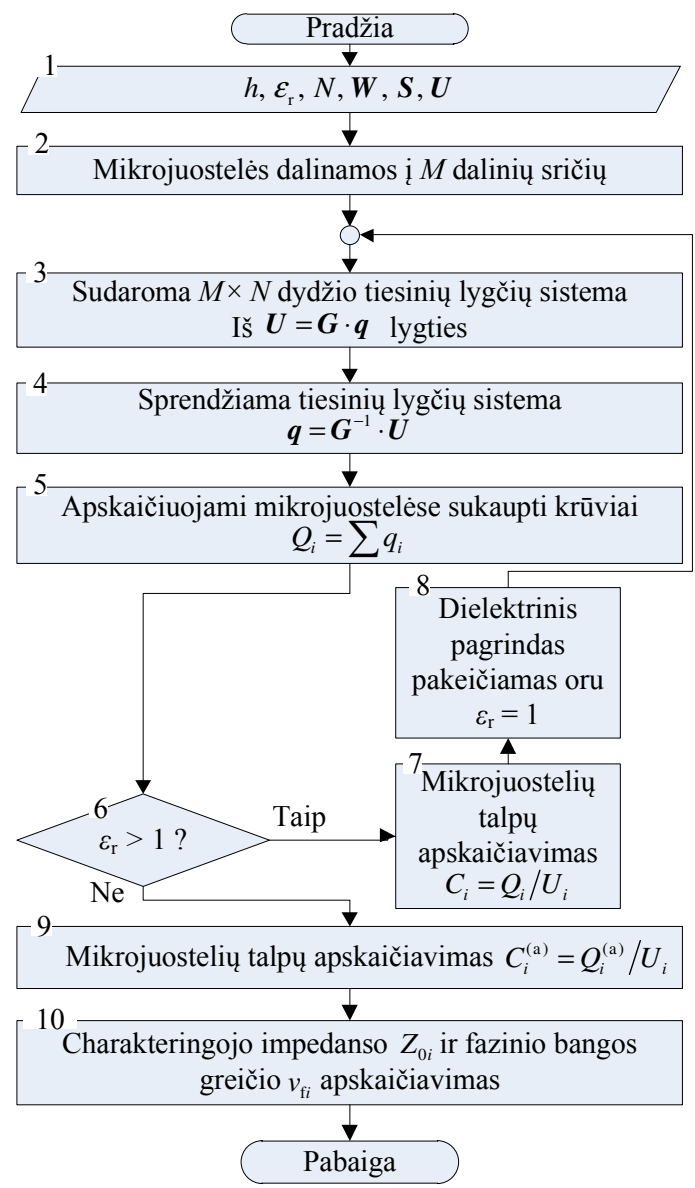

2.3 pav. Daugialaidès mikrojuostelinės linijos modelio, grịsto momentų metodu, supaprastintas algoritmas

Fig. 2.3. The simplified algorithm of the microstrip multiconductor line model based on method of moments

9. Apskaičiuojama kiekvienos homogeninès daugialaidès linijos mikrojuostelès ilginè talpa $C_{i}^{(\mathrm{a})}=Q_{i}^{(\mathrm{a})} / U_{i}$.

10. Apskaičiuojami mikrojuostelių charakteringieji impedansai ir TEM elektromagnetinès bangos sklidimo išilgai mikrojuostelès greičiai. 


\subsection{Daugialaidės mikrojuostelinès linijos modelių patikra}

Daugialaidès mikrojuostelinès linijos modelių patikra atlikta dviem etapais. Pirmame etape kokybiškai išnagrinètas potencialo ir krūvio pasiskirstymas mikrojuostelinès linijos, sudarytos iš 5 mikrojuostelių skerspjūvyje, siunčiant i mikrojuosteles vienodo dydžio ir ženklo ịtampas. Skaičiavimų rezultatai rodo, kad esant dideliems tarpams tarp mikrojuostelių, krūvio pasiskirstymas (2.4 pav., $a$ ir 2.5 pav., a) atitinka pasiskirstymą pavienėse mikrojuostelèse, kai sąryšio tarp jų galima nepaisyti. Tarpams tarp mikrojuostelių mažèjant (2.4 pav., $b$ ir 2.5 pav., $b$ ), jų visuma tampa panaši ị vieną plačią mikrojuostelę, kuriame potencialai ir krūviai pasiskirstę beveik tolygiai (2.4 pav., $c$ ir 2.5 pav., $c$ ).

Antrame modeliu patikros etape apskaičiuoti charakteringieji impedansai buvo lyginami su pateiktais mokslo publikacijoje (Janhsen et al. 1991), kurioje tiriama DML su dvejomis skirtingo pločio mikrojuostelemis spektro srities metodu. Palyginimo rezultatai pateikti 2.1 lentelëje. Iš lentelëje pateiktų duomenų matyti, kad pirmasis modelis pasižymi pakankamai dideliu nuokrypiu, kuris siekia $11 \%$ lyginio ir nelyginio linijos sužadinimo atveju. Be to pastebėta, kad nuokrypis dideja mažinant tarpus tarp mikrojuostelių, didžiausiu nuokrypiu pasižymi plačiausioji mikrojuostelè.

2.1 lentelè. Asimetrinès daugialaidès mikrojuostelinès linijos charakteringojo impedanso vertès esant lyginiam linijos sužadinimui $\left(Z_{0 \mathrm{~L} i}\right)$ ir nelyginiam sužadinimui $\left(Z_{0 \mathrm{~N} i}\right)$, apskaičiuotos spektrinès srities metodu (Janhsen et al. 1991) ir pasiūlytais metodais, kai $W_{1} / W_{2}=0,6 / 1,2 \mathrm{~mm}, h=0,62 \mathrm{~mm}$, ir $\varepsilon_{\mathrm{r}}=9,7$

Table 2.1. Values of characteristic impedance of asymmetrically coupled lines for even mode $\left(Z_{0 \mathrm{~L} i}\right)$, and odd mode $\left(Z_{0 \mathrm{~N} i}\right)$, calculated by spectral domain technique (Janhsen et al. 1991) and suggested models, when $W_{1} / W_{2}=0.6 / 1.2 \mathrm{~mm}, h=0.62 \mathrm{~mm}$, and $\varepsilon_{\mathrm{r}}=9.7$

\begin{tabular}{|c|c|c|c|c|c|c|c|c|c|c|c|c|}
\hline \multirow{2}{*}{$\begin{array}{l}S, \\
\mathrm{~m} \\
\mathrm{~m}\end{array}$} & \multicolumn{4}{|c|}{$\begin{array}{c}\text { Literatūros šaltinis (Janhsen } \\
\text { et al. 1991) }\end{array}$} & \multicolumn{4}{|c|}{ Pirmasis modelis } & \multicolumn{4}{|c|}{ Antrasis modelis } \\
\hline & $\begin{array}{c}\mathrm{Z}_{0 \mathrm{~L} I} \\
\Omega\end{array}$ & $\begin{array}{c}\mathrm{Z}_{0 \mathrm{~L} 2} \\
\Omega\end{array}$ & $\begin{array}{c}\mathrm{Z}_{0 \mathrm{~N} I} \\
\Omega\end{array}$ & $\begin{array}{c}\mathrm{Z}_{\mathrm{ON} 2} \\
\Omega\end{array}$ & $\begin{array}{c}\mathrm{Z}_{0 \mathrm{~L} l} \\
\Omega\end{array}$ & $\begin{array}{c}\mathrm{Z}_{\mathrm{OL} 2} \\
\Omega\end{array}$ & $\begin{array}{c}\mathrm{Z}_{0 \mathrm{~N} l} \\
\Omega\end{array}$ & $\begin{array}{c}\mathrm{Z}_{\mathrm{ON} 2} \\
\Omega\end{array}$ & $\begin{array}{c}\mathrm{Z}_{0 \mathrm{~L} l} \\
\Omega\end{array}$ & $\begin{array}{c}\mathrm{Z}_{0 \mathrm{~L} 2} \\
\Omega\end{array}$ & 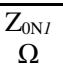 & $\begin{array}{c}\mathrm{Z}_{0 \mathrm{~N} 2} \\
\Omega\end{array}$ \\
\hline 0,1 & 75,5 & 43,9 & 35,0 & 20,7 & 74,1 & 43,0 & 31,0 & 22,5 & 72,7 & 42,4 & 34,6 & 20,2 \\
\hline 0,2 & 71,4 & 42,8 & 39,6 & 24,3 & 70,8 & 41,9 & 37,2 & 26,2 & 69,5 & 41,6 & 39,1 & 23,3 \\
\hline 0,3 & 68,5 & 42,1 & 42,8 & 26,4 & 68,2 & 41,0 & 41,3 & 28,4 & 67,0 & 40,8 & 41,8 & 25,5 \\
\hline 0,4 & 66,4 & 41,4 & 44,2 & 27,8 & 66,2 & 40,3 & $\overline{44,4}$ & 30,0 & 64,9 & 40,1 & 43,8 & 27,1 \\
\hline 0,5 & 64,2 & 40,7 & 46,4 & 29,2 & 64,6 & 39,7 & 46,8 & 31,2 & 63,2 & 39,6 & 45,3 & 28,3 \\
\hline 0,6 & 63,2 & 40,0 & 47,5 & 30,3 & 63,4 & 39,3 & 48,8 & 32,1 & 61,9 & 39,1 & 46,4 & 29,3 \\
\hline
\end{tabular}




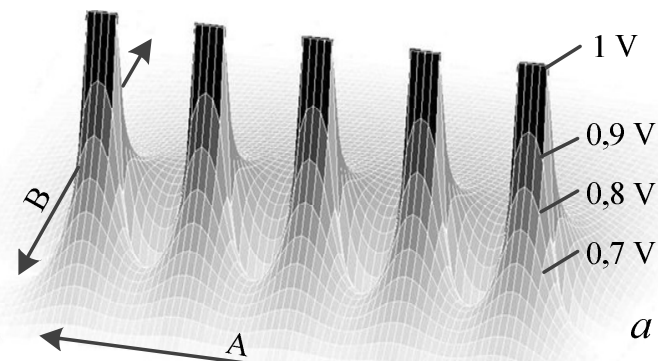

$a$

$c$

2.4 pav. Potencialų pasiskirstymas 5-ių mikrojuostelių daugialaidès linijos skerspjūvyje esant skirtingiems tarpams tarp laidininkų: $a-S=10$ gardelès žingsnių; $b-S=5$ gardelès žingsnių; $c-S=1$ gardelès žingsnis

Fig. 2.4. Potential distribution in the crossection of 5-conductors' microstrip multiconductor line at various spaces between conductors: $a-S=10$ mesh steps;

$$
b-S=5 \text { mesh steps; } c-S=1 \text { mesh steps }
$$




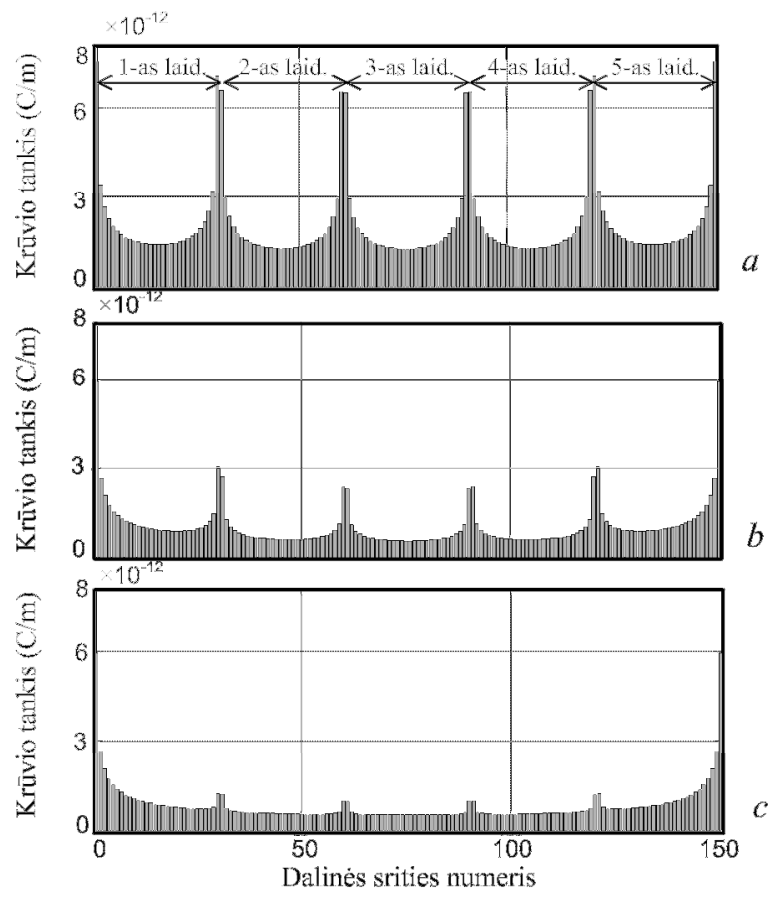

2.5 pav. Krūvio tankio pasiskirstymas 5-ių mikrojuostelių daugialaidès mikrojuostelinès linijos skerspjūvyje esant lyginiam jos sužadinimui ir įvairiems tarpams tarp mikrojuostelių: $a-S / W=1 ; b-S / W=0,3 ; c-S / W=0,03$

(tarpų grafikuose neparodyta)

Fig. 2.5. Charge distribution on 5-conductor' microstrip multiconductor line cross at various spaces between conductors: $a-S / W=1 ; b-S / W=0.3 ; c-S / W=0.03$

(spaces between microstrips are not shown)

Visi šie pastebèjimai gali būti paaiškinami BS metodo ịgyvendinimo specifika, pvz., kai tarpai tarp mikrojuostelių yra maži tampa sudètinga sudaryti tinkamą kontūrą apie kiekvieną mikrojuostelę ir tokiu būdu kontūras aplink plačiausią mikrojuostelę yra sunkiau ịgyvendinamas skaitiniu integravimu. Pastebètina, kad antrojo modelio apskaičiuoti charakteringieji impedansai visada yra šiek tiek mažesni už pateiktus literatūroje. Nepaisant to, antrojo modelio nuokrypis, lyginant su literatūroje paskelbtais neviršija 3,8 \%. Reikètų paminèti, kad charakteringujų impedansų vertès pateiktos (Janhsen et al. 1991), kai linijoje sklinda $10 \mathrm{GHz}$ signalas, o siūlomuose modeliuose ị tai nèra atsižvelgiama. 


\subsection{Daugialaidès mikrojuostelinès linijos modelių tyrimas}

DML modelių tyrimas taip pat buvo atliktas dviem etapais. Pirmame modelių tyrimo etape buvo nustatyta dielektriko nevienalytiškumo įtaka linijos savybėms. Šiam tikslui apskaičiuotas normuotasis krūvio tankio pasiskirstymas lyginiu būdu, kuomet žadintos 5 mikrojuostelių daugialaidès linijos skerspjūvyje, esant ịvairioms dielektrinių pagrindo $\varepsilon_{\mathrm{r}}$ vertèms (2.6 pav.) ir ịvairiems mikrojuostelių pločiams (2.7 pav.).

2.6 pav. pateiktos pasiskirstymo kreivès yra normuotos mažiausios krūvio tankio vertès atžvilgiu, kai dielektrinis pagrindas keičiamas oru $\left[q_{i} / \min \left(\left.q_{i}\right|_{\varepsilon_{\mathrm{r}=1}}\right)\right]$. Taigi šios kreivės iš tikruju vaizduoja krūvio tankio pasiskirstymo kitimą ịtaisant daugialaideje mikrojuostelinejje linijoje ịvairios skvarbos dielektrinius pagrindus. Matyti, kad ịtaisant dielektrini pagrindą $\left(\varepsilon_{\mathrm{r}}>1\right)$ vienalytès terpès daugialaidèje linijoje $\left(\varepsilon_{\mathrm{r}}=1\right)$, krūvio pasiskirstymas kinta ne tik absoliučiuoju dydžiu, bet ir kokybiškai. Pažymėtina, kad vidinèse linijos mikrojuostelèse krūvio tankio pasiskirstymo kitimas iš esmès proporcingas $\varepsilon_{\mathrm{r}}$ kitimui, o kraštinèse mikrojuostelèse krūvio tankis ị $\varepsilon_{\mathrm{r}}$ kitimą reaguoja labiau.

I daugialaidès linijos terpès nevienalytiškumo kitimą jautriau reaguoja linijos, sudarytos iš siauresnių mikrojuostelių. Tarkime, iš 2.7 pav. pateiktų pasiskirstymų matyti, kad DML, sudarytoje iš siaurų mikrojuostelių ( $W / h=0,1$ ), normuotojo krūvio tankio kraštinèse mikrojuostelèse kaupiasi beveik du kartus daugiau nei plačių mikrojuostelių linijoje $(W / h=10)$. Pažymėtina, kad 2.7 pav. kreivių normavimas atliktas tam tikro pasiskirstymo mažiausios krūvio tankio vertès $\left[q_{i} / \min \left(q_{i}\right)\right]$ atžvilgiu.

Antrame etape buvo tiriamas baigtinio mikrojuostelių skaičiaus daugialaidès linijos parametrų reguliarumas. Vienas iš svarbiausių daugialaidès linijos parametru yra jos mikrojuostelių charakteringasis impedansas esant lyginiam ir nelyginiam linijos sužadinimui. 2.8 pav. 


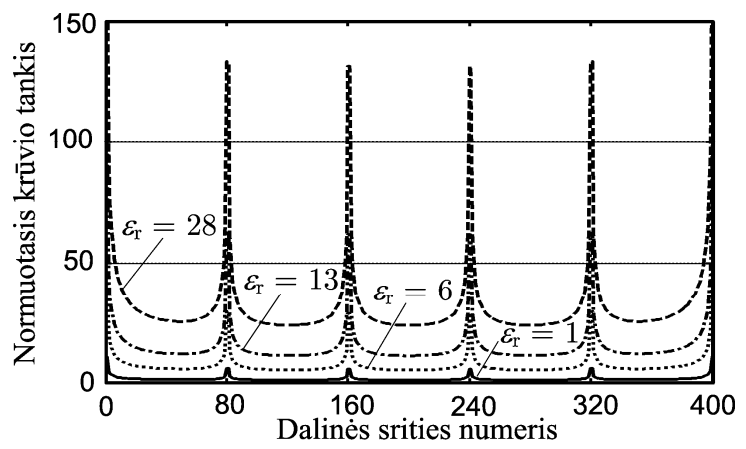

2.6 pav. Normuotasis krūvio tankio pasiskirstymas $\left[q_{i} /, \min \left(\left.q_{i}\right|_{\varepsilon_{\mathrm{r}=1}}\right)\right]$ 5-ių mikrojuostelių daugialaidès linijos skerspjūvyje, esant lyginiam jos sužadinimui ir ịvairioms dielektrinių pagrindo skvarboms, kai, $W / h=1 S / h=0,5$

(tarpų grafikuose neparodyta)

Fig. 2.6. Normalized distribution $\left[q_{i} /, \min \left(\left.q_{i}\right|_{\varepsilon_{\mathrm{r}=1}}\right)\right]$ of the charge in cross-section of 5-conductors' microstrip multiconductor line at various values of dielectric permittivity, when $W / h=1, S / h=0.5$ (spaces between microstrips are not shown)

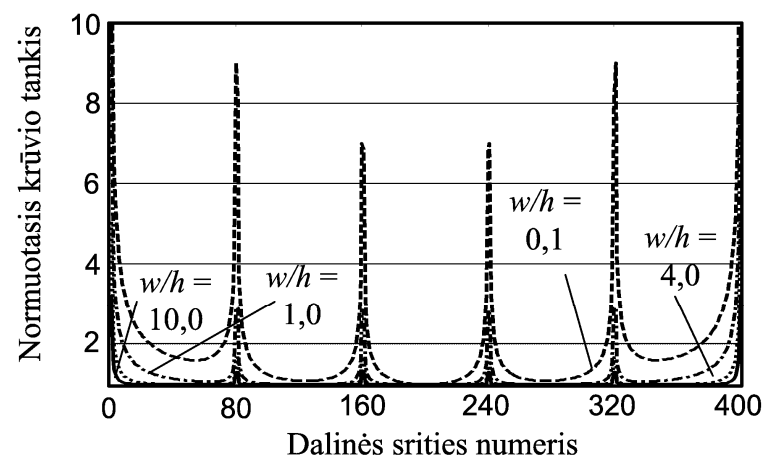

2.7 pav. Normuotojo krūvio tankio pasiskirstymas $\left[q_{i} /, \min \left(q_{i}\right)\right]$ 5-ių mikrojuostelių daugialaidès linijos skerspjūvyje, esant lyginiam jos sužadinimui ir ịvairiems mikrojuostelių pločiams, kai $S / h=0,1, \varepsilon_{\mathrm{r}}=9,6$ (tarpų grafikuose neparodyta)

Fig. 2.7. Normalized distribution of the charge $\left[q_{i} /, \min \left(q_{i}\right)\right]$ in cross-section of 5-conductors' microstrip multiconductor line at various values strip width, when $S / h=0.1, \varepsilon_{\mathrm{r}}=9.6$ (spaces between microstrips are not shown) 


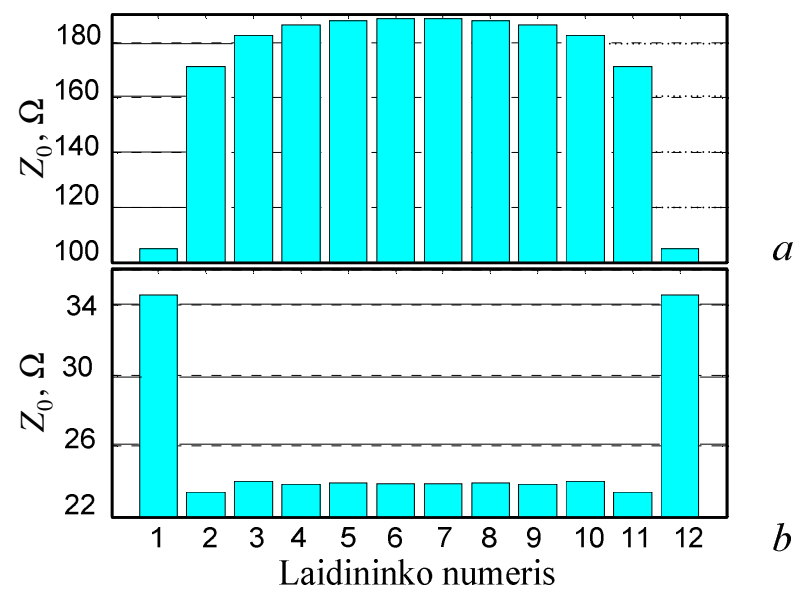

2.8 pav. 12-os mikrojuostelių daugialaidès linijos charakteringųjų impedansų histogramos esant lyginiam (a) ir nelyginiam (b) linijos sužadinimui, kai $W / h=0,5$,

$$
S / h=0,1
$$

Fig. 2.8. Characteristic impedances of 12-conductors' microstrip multiconductor line for even mode $(a)$ and odd mode $(b)$, when $W / h=0.5, S / h=0.1$

Pateiktos 12 mikrojuostelių daugialaidès linijos charakteringujų impedansų histogramos, liudijančios, kad charakteringujjų impedansų vertès linijoje pasiskirste labai nereguliariai ir tik vidinių mikrojuostelių varžos skiriasi nedaug.

Visų 2.2 lentelèje apžvelgtų daugialaidžių mikrojuostelinių linijų mikrojuostelių skaičius yra lyginis, taigi pateiktos tik pusès kiekvienos linijos mikrojuostelių charakteringụjų impedansų vertès. Lentelëje matyti, kad kraštinių ir vidurinių mikrojuostelių charakteringojo impedanso vertès skiriasi daugiau nei $40 \%$ ir lyginio, ir nelyginio sužadinimo atveju. Charakteringojo impedanso verčiu kitimas nuo kraštinių mikrojuostelių link vidinių yra didèjančio pobūdžio, liniją sužadinant lyginiu būdu ir šiek tiek svyruojantis, liniją sužadinant nelyginiu būdu. 
2.2 lentelė. Baigtinių mikrojuostelių skaičiaus DML charakteringųų impedansų vertės ir santykiniai nuokrypiai nuo reguliariųų verčių, kai $W / h=0,5 ; S / h=0,1$ ir $\varepsilon_{\mathrm{r}}=9,6$

Table 2.2. Values of a characteristic impedance of conductors of microstrip MCL and their relative deviations from regular values, when $W / h=0.5, S / h=0.1$, and $\varepsilon_{\mathrm{r}}=9.6$

\begin{tabular}{|c|c|c|c|c|c|c|c|c|}
\hline \multirow{3}{*}{$\begin{array}{l}\text { Laidi- } \\
\text { ninko } \\
\text { Nr. }\end{array}$} & \multicolumn{8}{|c|}{ Laidininkų daugialaidèje linijoje skaičius } \\
\hline & \multicolumn{2}{|c|}{$N=12$} & \multicolumn{2}{|c|}{$N=10$} & \multicolumn{2}{|c|}{$N=8$} & \multicolumn{2}{|c|}{$N=6$} \\
\hline & $Z_{0 i}, \Omega$ & $\delta, \%$ & $Z_{0 i}, \Omega$ & $\delta, \%$ & $Z_{0 i}, \Omega$ & $\delta, \%$ & $Z_{0 i}, \Omega$ & $\delta, \%$ \\
\hline \multicolumn{9}{|c|}{ Lyginis daugialaidès linijos sužadinimas } \\
\hline 6 & 104,7711 & $-44,5$ & - & - & - & - & - & - \\
\hline 5 & 171,1795 & $-9,22$ & 104,4080 & $-43,9$ & - & - & - & - \\
\hline 4 & 182,5038 & $-3,21$ & 170,4065 & $-8,43$ & 103,8859 & $-43,1$ & - & - \\
\hline 3 & 186,2541 & $-1,22$ & 181,4666 & $-2,49$ & 169,2276 & $-7,29$ & 103,0605 & $-41,6$ \\
\hline 2 & 187,8860 & $-0,36$ & 184,9057 & $-0,64$ & 179,7858 & $-1,51$ & 167,1675 & $-5,25$ \\
\hline 1 & 188,5571 & 0 & 186,1035 & 0 & 182,5355 & 0 & 176,4252 & 0 \\
\hline \multicolumn{9}{|c|}{ Nelyginis daugialaidès linijos sužadinimas } \\
\hline 6 & 34,5676 & 44,9 & - & - & - & - & - & - \\
\hline 5 & 23,3885 & $-1,98$ & 34,5592 & 44,74 & - & - & - & - \\
\hline 4 & 23,9902 & 0,55 & 23,3919 & $-2,03$ & 34,5442 & 44,9 & - & - \\
\hline 3 & 23,8188 & $-0,17$ & 23,9855 & 0,45 & 23,3986 & $-1,86$ & 34,5132 & 44,2 \\
\hline 2 & 23,8872 & 0,11 & 23,8254 & $-0,22$ & 23,9751 & 0,56 & 23,4154 & $-2,19$ \\
\hline 1 & 23,8600 & 0 & 23,8771 & 0 & 23,8424 & 0 & 23,9401 & 0 \\
\hline
\end{tabular}

Pažymėtina, kad daugialaidès mikrojuostelinès linijos charakteringųjų impedansų verčių artėjimas prie reguliariụjų verčių yra spartesnis liniją sužadinant nelyginiu būdu.

\subsection{Antrojo skyriaus išvados}

1. Taikant baigtinių skirtumų (BS) ir momentų metodus (MoM) sukurti du matematiniai modeliai baigtinio dydžio daugialaidžių mikrojuostelinių linijų (DML) elektriniams parametrams apskaičiuoti.

- Palyginus skaičiavimo pagal sukurtus matematinius modelius rezultatus su kitų autorių kitais metodais gautais rezultatais, atskleista, kad sudarytieji modeliai teisingi, padarytos prielaidos leistinos, o naudojant sukurtają programinę ịrangą galima ịvertinti reiškinius baigtinio laidininkų skaičiaus daugialaidèse linijose ir sumažinti DML elektrinių parametrų skaičiavimo paklaidą. 
- Išnagrinèta dielektrinès terpès nevienalytiškumo ịtaka DML charakteristikoms. Parodyta, kad dielektriko nevienalytiškumas iš esmès nekeičia krūvio pasiskirstymo pobūdžio DML skerspjūvyje. Dielektrinio pagrindo $\left(\varepsilon_{\mathrm{r}}>1\right)$ ịtaisymas vienalytėje daugialaidèje linijoje (kurios $\varepsilon_{\mathrm{r}}=1$ ) didina krūvius visose mikrojuosteliu skerspjūvio dalinėse srityse proporcingai pagrindo santykinei dielektrinei skvarbai.

2. Nagrinètos nereguliarios, t. y. sudarytos iš baigtinio mikrojuostelių skaičiaus daugialaidès linijos.

- Parodyta, kad vidiniuose linijos mikrojuostelèse krūvio pasiskirstymas kinta proporcingai $\varepsilon_{\mathrm{r}}$ keitimuisi, o kraštinèse mikrojuostelèse krūvio tankis ị $\varepsilon_{\mathrm{r}}$ kitimą reaguoja labiau.

- Pastebèta, kad nagrinètais atvejais kraštinių ir vidinių mikrojuostelių charakteringieji impedansai gali skirtis daugiau nei 1,5 karto, DML sužadinant lyginiu ir nelyginiu būdu. Charakteringojo impedanso verčių kitimas nuo kraštinių mikrojuostelių link vidinių yra didejjančio pobūdžio esant lyginiam sužadinimui ir mažejjantis bei šiek tiek svyruojantis, sužadinant nelyginiu būdu.

- Nustatyta, kad DML charakteringujų impedansų verčių artėjimas prie reguliariųų verčių yra spartesnis nelyginio sužadinimo atveju.

3. Programinès ịrangos, sudarytos remiantis pasiūlytais DML matematiniais modeliais. Bandymai parodè, kad modelio, grịsto momentų metodu taikymas yra efektyvesnis negu taikymas modelio, grịsto BS metodu. Tarkime, analizė dvylikos mikrojuostelių DML identiškos skyros (kiekviena mikrojuostelè sudaryta iš 50 dalių) pirmuoju modeliu užtruko 28 minutes (analizuojama sritis - 100×1500 ląstelių), o taikant antraji modeli - šiek tiek ilgiau nei 2 minutes (kompiuteris PC, CPI - Intel® Core ${ }^{\mathrm{TM}} 2$ Duo E6750 @ 2,66 GHz, standžiojo disko talpa - $160 \mathrm{~GB}$, pagrindinès atminties talpa - $2 \mathrm{~GB}$, operacinè sistema - MS Windows $\mathrm{XP})$. 



\section{Lygiagrečioji daugialaidžių mikrojuostelinių linijų analizè ir sintezè}

Šiame skyriuje pateikta lygiagrečioji daugialaidžių mikrojuostelinių linijų (DML) analizès metodika, grịsta uždavinio lygiagretumo principu ir DML sintezès metodika, grịsta duomenų lygiagretumo principu.

Skyriaus tematika autoriaus paskelbti du straipsniai (Pomarnacki et al. 2010; Pomarnacki, Krukonis 2011)

\subsection{Daugialaidès mikrojuostelinès linijos analizè}

DML konstrukcijos eskizas pateiktas 3.1 pav. Mikrojuostelès tokioje linijoje formuojamos dielektrinio pagrindo paviršiuje, kita pagrindo pusė padengta ištisiniu laidžiu sluoksniu, atliekančiu ekrano funkciją. 


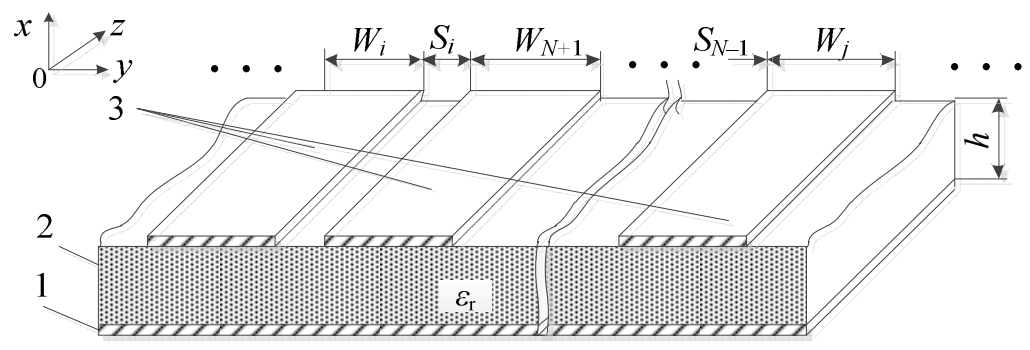

3.1 pav. Daugialaidès mikrojuostelinès linijos konstrukcija:

1 - izžemintas laidininkas (ekranas); 2 - dielektrinis pagrindas; 3 - mikrojuostelès

Fig. 3.1. Construction of the microstrip multiconductor line:

1 - conducting shield; 2 - dielectric substrate; 3 - microstrips

Bendruoju atveju DML yra sudaryta iš $N$ mikrojuostelių (kurioms priskiriamas ir ištisinis ekranas), kuriomis gali sklisti $N$ normaliujų bangų (Paul 2008). Skirtingų tipų normaliųų bangų fazinis ir grupinis greičiai skiriasi, todèl DML susidaro sklindančių bangų interferencija (trikdžiai) ir perduodami signalai yra iškraipomi. Tokiu būdu informacijai perduoti rekomenduojama naudoti tiktai normaliąsias bangas (Кравцов 2011).

Modeliuojant ịvairius mikrobangu ịtaisus, kuriuose taikomos DML pakanka analizuoti dvi pagrindines normaliąsias bangas (Martavičius et al. 1996). Pirmoji yra sinfazine normalioji banga (angl. c-mode), kuri yra sužadinama i gretimas DML mikrojuosteles siunčiant vienodos fazès įtampas (fazių skirtumas tarp jų lygus 0) - lyginis DML sužadinimas ir priešfaziné normalioji banga (angl. $\pi$-mode), kuri sužadinama kai DML gretimų mikrojuostelių įtampų fazių skirtumas lygus $\pi$ radianų - nelyginis DML sužadinimas (Martavičius et al. 1996). Pagrindinès DML charakteristikos yra santykinė efektyvioji dielektrinė skvarba, per kurią išsireiškia bangos sklidimo greitis, ir charakteringasis impedansas, kurie gali būti surasti taikant kvazi-TEM artini, bei skaitinius metodus pvz., baigtinių skirtumų, baigtinių elementu (Burokas, Štaras 2008) arba momentų metodus (Wei et al. 1984, Urbanavičius et al. 2007). Pažymètina, kad nagrinėjamam objektui tampant sudètingesniu (DML atveju, didejjant mikrojuostelių skaičiui, sudètingèjant mikrojuostelių išsidèstymui arba mažinant leistiną skaičiavimų neapibrěžtị) skaitinių metodų igyvendinimas reikalauja didelių kompiuterio resursų: CPİ skaičiavimo laiko ir operatyviosios atminties talpos (Cheng 2008). Siekiant apeiti šiuos apribojimus galima sprendžiamą uždavinị paskirstyti kompiuterių telkiniui - turi būti sukurta lygiagrečioji analizės sistema.

Šiame poskyryje pasiūlytas ir ištirtas DML analizès lygiagretusis algoritmas, grịstas užduoties lygiagretinimo principu. Poskyris sudarytas sekančiu bū- 
du. Skirsnyje 3.1.1 aprašytas siūlomas lygiagretusis algoritmas. Algoritmo patikra, jo efektyvumo tyrimas ir skaičiavimų rezultatai pateikti 3.1.2 skirsnyje.

\subsubsection{Lygiagretusis daugialaidès mikrojuostelinès linijos analizès algoritmas}

Praktiškai bet koks skaičiavimo procesas gali būti organizuotas lygiagrečiai - skaičiavimo veiksmai paskirstyti keliems kompiuteriams. Kuriant lygiagrečiają sistemą skaičiavimų trukmè mažèja, tačiau daugèja keitimosi duomenų tarp kompiuterių, kurie didina skaičiavimų trukmę (Čiegis et al. 2005).

Pagrindinès DML charakteristikos: santykinė efektinė dielektrinė skvarba ir mikrojuostelių charakteringasis impedansas apskaičiuojamos žinant mikrojuostelių ilgines talpas:

$$
\begin{gathered}
\varepsilon_{\mathrm{ref}}=\frac{C_{i}}{C_{i}^{(\mathrm{a})}}, \\
Z_{0 i}=\frac{1}{\mathrm{c}_{0} \sqrt{C_{i} C_{i}^{(\mathrm{a})}}},
\end{gathered}
$$

čia $c_{0}$ - šviesos greitis vakuume; $C_{i}$ - DML $i$-osios mikrojuostelès ilginè talpa; $C_{i}^{(\mathrm{a})}-i$-osios mikrojuostelès ilginè talpa, kai dielektrinis pagrindas pakeičiamas oru $\left(\varepsilon_{\mathrm{r}}=1\right)$. Analizuojant DML, skaičiavimai pagal (3.1) ir (3.2) formules atliekami du kartus - esant sinfazinei ir priešfazinei normaliosioms bangoms. Taigi visoms DML charakteristikoms apskaičiuoti tenka atlikti keturias skaičiavimo operacijas: 1) DML mikrojuostelių ilginių talpų apskaičiavimas esant sinfazinei normaliajai bangai; 2) mikrojuostelių ilginių talpų apskaičiavimas esant priešfazinei normaliajai bangai; 3) mikrojuostelių ilginių talpų apskaičiavimas esant sinfazinei normaliajai bangai ir dielektrinis pagrindas pakeistas oru; 4) mikrojuostelių ilginių talpų apskaičiavimas esant priešfazinei normaliajai bangai ir dielektrinį pagrindą pakeitus oru.

DML analizès trukmei sumažinti išvardintas keturias skaičiavimo operacijas tikslinga paskirstyti tarp lygiagrečios sistemos kompiuterių (mazgų). Šiuo atveju kiekvienas mazgas turès pradinius konstrukcinius ir elektrinius DML parametrus, kuriuos taikant bus atliekami ilginių talpų skaičiavimai. Lygiagrečiojo DML analizės algoritmo, grịsto uždavinio lygiagretinimo principu, blokinè schema pateikta 3.2 pav. Šiame algoritme naudojamas ,valdantysis-pavaldusis” lygiagrečiojo programavimo būdas (Almeida et al. 2004). 
Algoritmą sudaro 7 žingsniai:

1. Ivedami pradiniai konstrukciniai ir elektriniai DML parametrai: dielektrinio pagrindo santykiné dielektriné skvarba $\varepsilon_{\mathrm{r}}$ ir aukštis $h$; mikrojuostelių pločiai $W_{i}$ ir tarpai tarp mikrojuostelių $S_{i}$; analizuojamos srities dydžiai $A$ ir $B$.

2. Apskaičiuojami tarpiniai DML parametrai: ribinès dielektrinės skvarbos vertès sąsajoje tarp dielektrinio pagrindo ir oro, mikrojuostelių pozicijos analizuojamoje srityje.

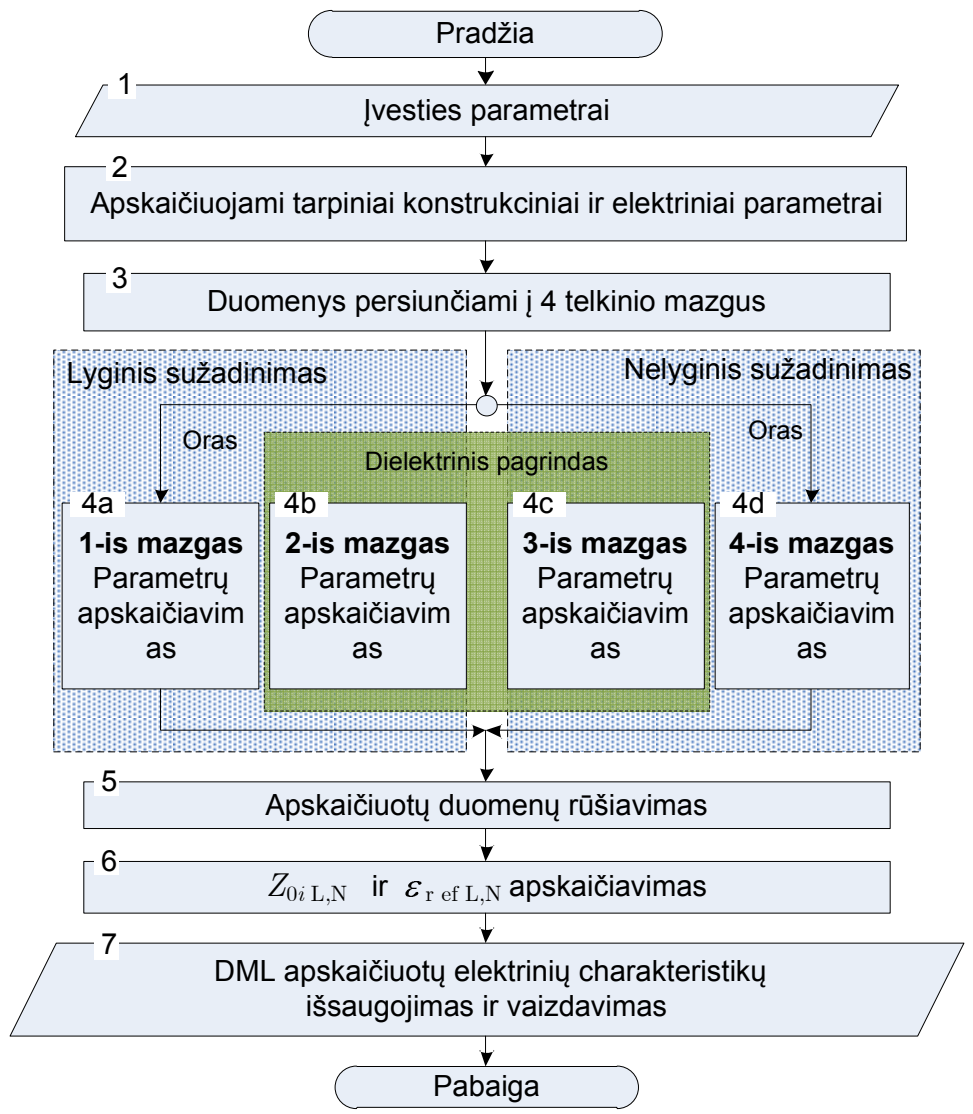

3.2 pav. Daugialaidès mikrojuostelinès linijos analizès lygiagretusis algoritmas Fig. 3.2. Flowchart of the analysis of parallel algorithm of the MMCL 
3. Keturiems pavaldiesiems mazgams siunčiami DML pradiniai ir apskaičiuoti tarpiniai parametrai.

4. Kiekvienas mazgas apskaičiuoja ilgines talpas, esant tam tikrai normaliajai bangai ir dielektrinei terpei. Mazgai 2 ir 3 apskaičiuoja ilgines talpas esant sinfazinei ir priešfazinei normaliosioms bangoms ir kai linijoje yra dielektrinis pagrindas, tuo tarpu mazgai 1 ir 4 skaičiuoja ilgines talpas esant toms pačioms normaliosioms bangoms, kuomet dielektrinis pagrindas linijoje yra pakeičiamas oru.

5. Apskaičiuotos mikrojuostelių ilginès talpos persiunčiamos valdančiajam kompiuteriui.

6. Valdančiajame mazge rūšiuojami gauti rezultatai ir apskaičiuojami mikrojuostelių charakteringieji impedansai ir santykinès efektyviosios dielektrinès skvarbos.

7. Apskaičiuoti rezultatai yra išsaugojami ir vaizduojami.

\subsubsection{Lygiagrečiojo algoritmo tyrimas}

Pasiūlytas lygiagretusis algoritmas (3.2 pav.) buvo igyvendintas homogeniniame MPICH2 telkinyje, sudarytame iš penkių kompiuterių (kompiuterio CPI - Pentium ${ }^{\mathrm{TM}}$ 4, 2,8 GHz; operatyviosios atminties talpa - $512 \mathrm{MB}$; standžiujuc diskų talpa - $80 \mathrm{~GB}$; operaciné sistema - Fedora 6; kompiuterių tinklas - Ethernet $100 \mathrm{Mb} / \mathrm{s}$ ). Tyrimo metu kompiuterių telkinio mazgu skaičius buvo keičiamas nuo 1 iki 5 siekiant nustatyti algoritmo vykdymo trukmę esant ịvairiam mazgų skaičiui. Algoritmo vykdymo trukmė bei spartinimo ir efektyvumo koeficientų vertès pateiktos 3.1 lentelèje.

Siūlomame lygiagrečiajame algoritme DML analizè gali būti atliekama taikant bet kurị skaitinị metodą. Mūsų atveju lygiagretusis algoritmas ịgyvendintas taikant baigtinių skirtumų metodą. Skaičiavimo procedūroms paspartinti buvo pritaikytas tiesioginis potencialų apskaičiavimo būdas ir išretintos matricos (Krukonis 2010).

Lygiagrečiojo algoritmo spartos pokytis apskaičiuojamas pagal tokią išraišką:

$$
\Delta S_{p}=\frac{t_{1}-t_{p}}{t_{p}} 100 \%,
$$


3.1. lentelè. Lygiagrečiojo DML analizės algoritmo vykdymo parametrai*

Table 3.1. Execution parameters of the algorithm of MMCL*

\begin{tabular}{|c|c|c|c|c|c|}
\hline $\begin{array}{c}\text { Algoritmo vykdy- } \\
\text { mo parametrai }\end{array}$ & \multicolumn{5}{|c|}{ Mazgu skaičius telkinyje } \\
\cline { 2 - 6 } & 1 & 2 & 3 & 4 & 5 \\
\hline Vykdymo trukme, $\mathrm{s}$ & 136 & 80 & 78 & 39 & 38 \\
\hline$\Delta S_{p}, \%$ & - & 70.0 & 74,4 & 248,7 & 257,9 \\
\hline$S_{p}$ & 1 & 1,7 & 1,74 & 3,49 & 3,58 \\
\hline$E_{p}$ & 1 & 0,85 & 0,58 & 0,87 & 0,72 \\
\hline
\end{tabular}

* Procesų skaičius $P=5=$ const .

čia $t_{1}$ - DML analizės algoritmo vykdymo trukmė esant vienam skaičiavimo mazgui; $t_{p}$ - DML analizės algoritmo vykdymo trukmé esant $p$ mazgams. Lygiagrečiojo algoritmo spartinimo koeficientas apibūdina spartinimą, kuris pasiekiamas sprendžiant uždavinị naudojant $p$ mazgų, ir apskaičiuojamas pagal tokią išraišką (Čiegis 2005):

$$
S_{p}=\frac{t_{1}}{t_{p}},
$$

čia $t_{1}$ - algoritmo vykdymo trukmé esant vienam kompiuteriui; $t_{p}$ - algoritmo vykdymo trukmè, esant $p$ mazgų skaičiui telkinyje. Kitas svarbus lygiagrečiojo algoritmo rodiklis yra algoritmo efektyvumo koeficientas, apibūdinantis, kokia dalis lygiagrečiosios kompiuterinès sistemos pasitelkta sprendžiant uždavini duotuoju lygiagrečiuoju algoritmu (Čiegis 2005):

$$
E_{p}=\frac{S_{p}}{p} .
$$

Lygiagrečiojo algoritmo efektyvumo tyrime buvo apskaičiuojama $5 \cdot 10^{4}$ elementų analizuojama sritis. 3.1 lentelèje matyti, kad, esant lyginiam mazgų skaičiui kompiuterių telkinyje (pvz., $2 n$ ) algoritmo efektyvumas yra šiek tiek mažesnis negu tuomet, kai telkinị sudaro $2 n+1$ mazgas. Esant nelyginiam mazgų skaičiui telkinyje sudarytus procesus vykdo ir valdantysis mazgas. Didžiausias efektyvumas gautas naudojant 5 telkinio mazgus šiuo atveju algoritmo vykdymo trukmė yra net 3,6 karto didesnė už algoritmą vykdant viename mazge.

Tai pat buvo patikrintas algoritme naudojamo DML matematinio modelio adekvatumas lyginant apskaičiuotus DML parametrus su gautais momentų ir spektro srities (Tripathi et al. 1989) metodais. Apskaičiuoti analizuojamos DML 
parametrai pateikti 3.2 lentelèje. Pastebètina, kad apskaičiuotu lygiagrečiuoju algoritmu DML parametru santykinis skirtumas su DML parametrais, gautais kitais analizès metodais, neviršija $3 \%$, taigi galima teigti, kad siūlomas algoritmas yra pakankamai tikslus inžineriniams skaičiavimams vykdyti.

3.2 lentelè. Keturių susietujų mikrojuostelių linijos parametrų*, gautų naudojant pasiūlytą algoritmą (lygiagretusis algoritmas, grịstas BS metodu) ir naudojant momentų ir spektrinès srities (Tripathi et al. 1989) metodu palyginimas

Table 3.2. Comparison parameters for four coupled microstrip lines* obtained using the proposed technique (parallel algorithm with the FDM), the MoM, and the spectral domain method (Tripathi et al. 1989)

\begin{tabular}{|c|c|c|c|c|c|c|}
\hline \multirow{2}{*}{$\begin{array}{c}\text { Mikrojuostelès } \\
\text { nr. }\end{array}$} & \multicolumn{3}{|c|}{ Sinfazinė normalioji banga } & \multicolumn{3}{|c|}{$\begin{array}{c}\text { Priešfazinė normalioji } \\
\text { banga }\end{array}$} \\
\hline & \begin{tabular}{|c|} 
Lygiagretus \\
algoritmas
\end{tabular} & $\begin{array}{l}\text { Iš (Tripathi } \\
\text { et al. 1989) }\end{array}$ & $\begin{array}{l}\text { Momentuc } \\
\text { metodas }\end{array}$ & $\begin{array}{c}\text { Lygiagretus } \\
\text { algoritmas }\end{array}$ & $\begin{array}{l}\text { Iš (Tripathi } \\
\text { et al. 1989) }\end{array}$ & $\begin{array}{l}\text { Momentu } \\
\text { metodas }\end{array}$ \\
\hline \multicolumn{7}{|c|}{ Santykinė efektyvioji dielektrinė skvarba } \\
\hline Nuo 1 iki 4 & 7,32 & 7,55 & 7,54 & 5,42 & 5,45 & 5,42 \\
\hline \multicolumn{7}{|c|}{ Charakteringasis impedansas, $\Omega$} \\
\hline 1 ir 4 & 65,25 & 66 & 66 & 24,35 & 24 & 24 \\
\hline 2 ir 3 & 119,5 & 123 & 121 & 41,67 & 42 & 41 \\
\hline
\end{tabular}

* $W_{1}=W_{4}=0,6 \mathrm{~mm}, W_{2}=W_{3}=0,3 \mathrm{~mm}, S_{1}=S_{4}=0,3 \mathrm{~mm}, S_{2}=0,2 \mathrm{~mm}$, $h=0,635 \mathrm{~mm}, \varepsilon_{\mathrm{r}}=9,6$.

Toliau, taikant pasiūlytą algoritmą buvo tirtos santykinės efektyviosios dielektrinès skvarbos ir charakteringojo impedanso priklausomybės nuo DML konstrukcinių matmenų. Apskaičiuotų DML parametrų priklausomybės nuo normalizuotų mikrojuostelių pločio $W / h$ ir tarpų tarp jų $S / h$ yra pateikti, atitinkamai 3.3 ir 3.4 pav. 

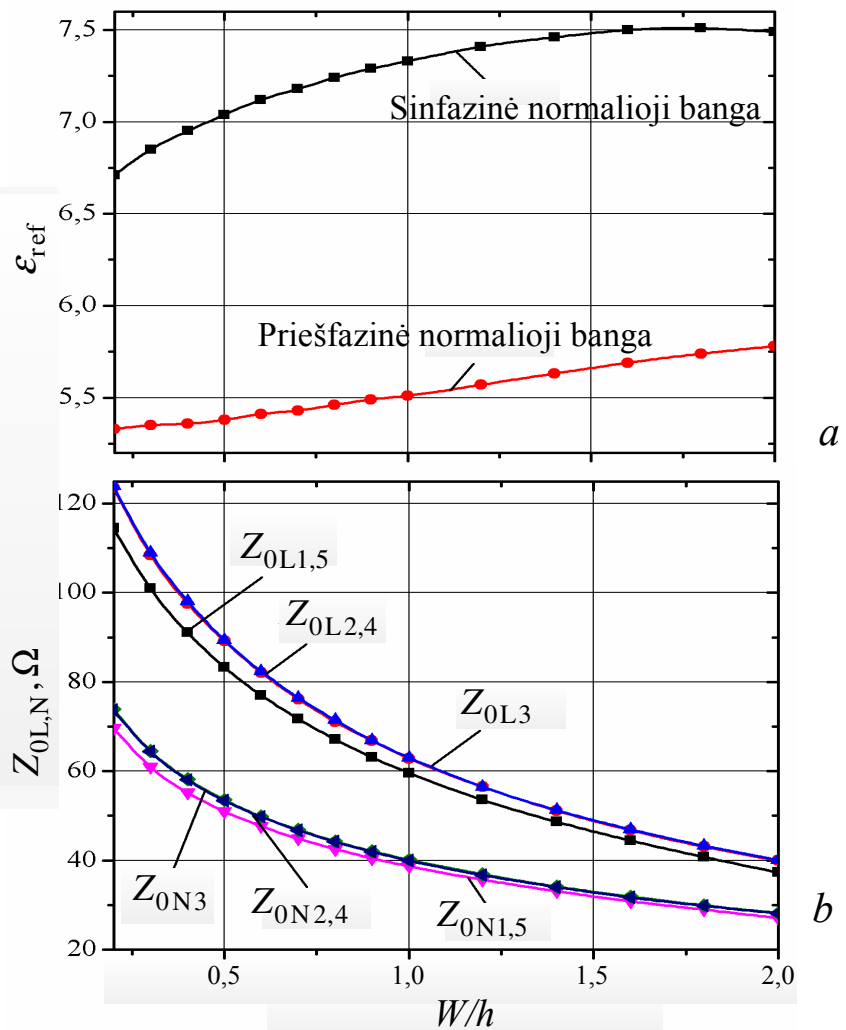

3.3 pav. Penkių simetriškai išdèstytų mikrojuostelių DML santykinès efektyviosios dielektrinès skvarbos $(a)$ ir charakteringojo impedanso $(b)$ priklausomybès nuo normalizuoto mikrojuostelių pločio: $S / h=1 ; \varepsilon_{\mathrm{r}}=9,6$

Fig. 3.3. Effective dielectric permittivity $(a)$; characteristic impedance $(b)$ of five-conductor symmetrically coupled MMCL versus the normalized microstrip width;

$$
S / h=1 ; \varepsilon_{\mathrm{r}}=9.6
$$




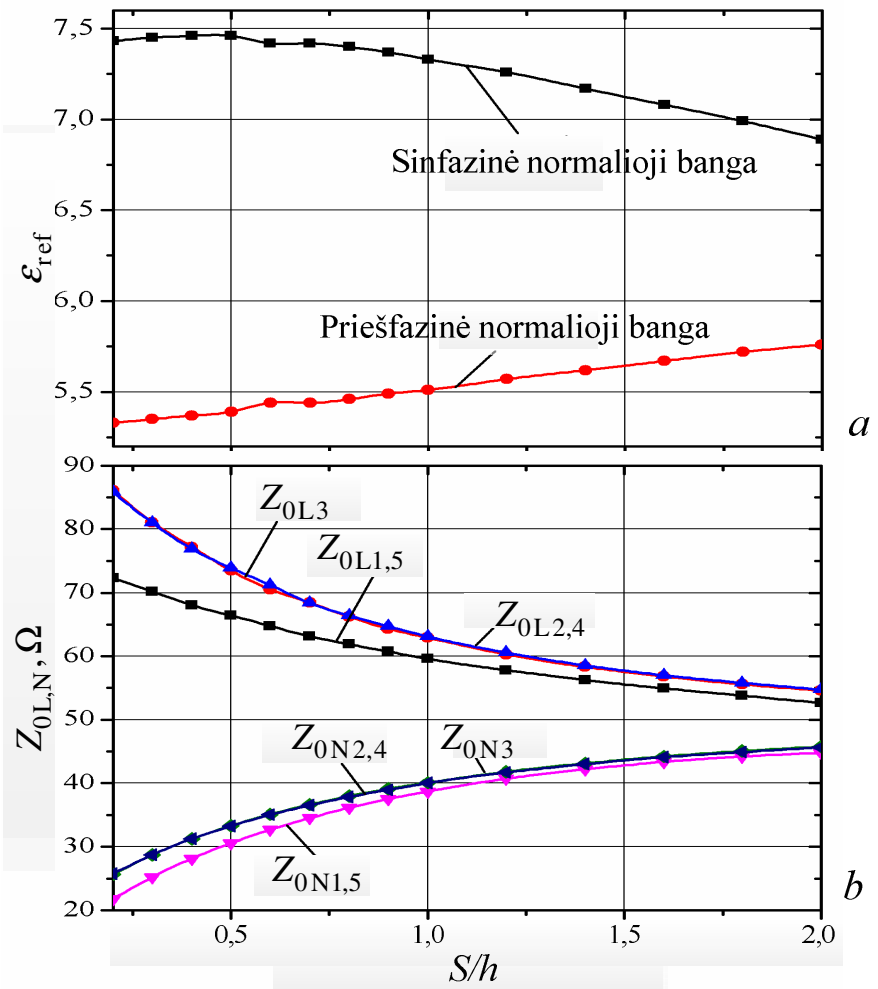

3.4 pav. Penkių simetriškai išdėstytų mikrojuostelių DML santykinès efektyviosios dielektrinès skvarbos $(a)$ ir charakteringojo impedanso $(b)$ priklausomybès nuo normalizuoto mikrojuostelių pločio: $W / h=1 ; \varepsilon_{\mathrm{r}}=9,6$

Fig. 3.4. Effective dielectric permittivity $(a)$; characteristic impedance $(b)$ of five conductor symmetrically coupled MMCL versus the normalized microstrip width;

$$
W / h=1 ; \varepsilon_{\mathrm{r}}=9.6
$$

3.3 ir 3.4 pav. matyti, kad didinant tarpą $S / h$ tarp mikrojuostelių, palaikant pastovų mikrojuostelių plotị $W / h$, arba atvirkščiai, didinant mikrojuostelių plotị nekeičiant atstumo tarp jų, pateiktų priklausomybių pobūdis iš esmès atitinka susietųu mikrojuostelinių linijų charakteristikų pobūdi (Urbanavičius et al. 2007). Pastebėtina, kad charakteringasis impedansas vidinių mikrojuostelių (3.3 pav., $b$ ir 3.4 pav. $b$ atitinkamos kreivės pažymėtos skaičiais 2,3 ir 4 ) praktiškai sutampa esant ir sinfazinei normaliajai bangai ir priešfazinei normaliajai 
bangai. Šių mikrojuostelių charakteringojo impedanso santykinis skirtumas visame parametrų $W / h$ ir $S / h$ kitimo ruože neviršija $0,3 \%$, tai liudija apie DML, veikiančios normaliujų bangu režimu, vidinès elektromagnetinio lauko dalies sandaros vienalytiškumą net tuo atveju, kai DML sudaro tik penkios mikrojuostelès.

\subsection{Daugialaidès mikrojuostelinès linijos sintezè}

Sintezuojant DML tiksliniu parametru gali būti charakteringasis impedansas $Z_{0}$ arba santykinė efektyvioji dielektrinè skvarba $\varepsilon_{\text {ref }}$. DML naudojant kaip perdavimo liniją svarbiausiu parametru laikytinas charakteringasis impedansas, apibūdinantis jos suderinamumą su signaliniu traktu.

Sintezuojant bet kuri elektronini įtaisą tenka daug kartų vykdyti šio ịtaiso matematinio modelio analizę. Siekiant sumažinti projektavimo trukmę galime taikyti tikslinès funkcijos ekstremumo paieškos metodus (Pomarnacki, Urbanavičius 2009) arba analizès procesui naudoti lygiagrečiają kompiuterizuotą sistemą.

Šiame poskyryje pateikta DML konstrukcinių parametrų: dielektrinio pagrindo storio $h$ ir santykinès dielektrinès skvarbos $\varepsilon_{\mathrm{r}}$, laidininkų pločiu $W$ ir tarpų tarp jų $S$, atitinkančių nurodytą charakteringojo impedanso vertę ir nuokrypi nuo jos, radimo metodika, grịsta lygiagrečiuoju DML analizès algoritmu, aprašytu 3.1 poskyryje.

\subsubsection{Periodinès daugialaidès mikrojuostelinès linijos modelis}

DML analizei taikytini daugelis skaitinių metodų, pvz., baigtinių elementų metodas, momentų metodas ir kiti. Esamam uždaviniui spręsti pasirinktas baigtinių skirtumų (BS) metodas (Sadiku 2009), pasižymintis sąlyginiu paprastumu ir galimybe ịvertinti analizuojamos srities ypatumus, tarkime, viršutinị DML ekraną, mikrojuostelių storį ir pan.

Nagrinejjant DML, kurią sudaro didelis skaičius mikrojuostelių (3.1 pav.), baigtinių skirtumų metodu susiduriama su sunkumais pasirenkant analizuojamą sritị, kuri šiuo atveju yra proporcinga mikrojuostelių skaičiui ir gali būti labai didelè. Tačiau, jeigu DML sudaryta iš vienodo pločio mikrojuostelių ir tarpai tarp jų yra lygūs, tuomet DML modelyje galima ịvertinti linijos periodiškumą ir simetriją nagrinejjant tik mažają DML dali, kuri 3.5 pav. parodyta tarp 6 ir 8 arba 7 ir 8 plokštumų. 


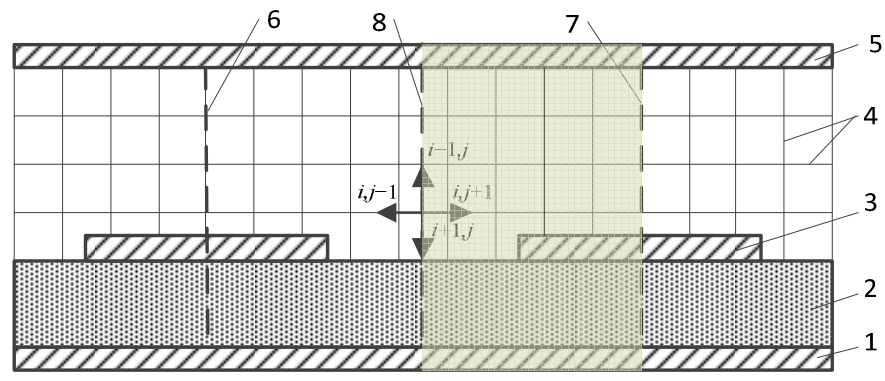

3.5 pav. Daugialaidès mikrojuostelinès linijos su periodinėmis plokštumomis modelis (analizuojama sritis patamsinta): 1 - apatinis ekranas; 2 - dielektrinis pagrindas;

3 - mikrojuostelinis signalinis laidininkas; 4 - analizuojamos srities gardelè;

5 - viršutinis ekranas; 6,7-mikrojuostelinių signalinių laidininkų periodiškumą ịvertinančios, kairioji ir dešinioji, plokštumos; 8 - tarpų tarp signalinių laidininkų periodiškumą ịvertinanti plokštuma

Fig. 3.5. The model of the multiconductor microstrip line with symmetric areas (area of analysis is shaded): 1 - bottom shield; 2 - dielectric substrate; 3 - microstrips; 4 - grid of the area of analyses; 5 - upper shield; 6, 7-planes where microstrips conductors are symmetric; 8 - plane where space between microstrips is symmetric

Taikant baigtinių skirtumų metodą trečioji Maksvelio lygtis diferencialine forma (Vainoris 2004) pakeičiama Laplaso lygtimi, kurios diferencialiniai elementai išreiškiami baigtiniais skirtumais:

$$
\varphi_{i, j}=\frac{\varphi_{i+1, j}+\varphi_{i-1, j}+\varphi_{i, j+1}+\varphi_{i, j-1}}{4},
$$

čia $\varphi_{i, j}$ - nagrinėjamo taško potencialas; $\varphi_{i \pm 1, j \pm 1}$ - gretutinių taškų potencialai.

Taigi, (3.6) lygtimi galima apskaičiuoti potencialus kiekviename analizuojamos srities taške. Atsižvelgus ị minètą DML periodiškumą, analizuojamos srities kraštuose t. y. ties 3.5 pav. pateiktomis 6 ir 7 plokštumomis, lygtis (3.6) privalo būti pakeista (Štaras 2008). Tokiu atveju (3.6) lygtis ties dešiniaja riba (3.5 pav. 7-oji plokštuma) pasikeis i

$$
\varphi_{i, j}=\frac{1}{4}\left(2 \varphi_{i-1, j}+\varphi_{i, j-1}+\varphi_{i, j+1}\right),
$$

o ties kairiaja riba (3.5 pav. 8-oji plokštuma) i 


$$
\varphi_{i, j}=\frac{1}{4}\left(2 \varphi_{i+1, j}+\varphi_{i, j-1}+\varphi_{i, j+1}\right) .
$$

Taigi, (3.7) ir (3.8) lygtimis galima ìvertinti analizuojamos DML periodiškumą, žymiai sumažinti analizuojamos srities dydị ir tokiu būdu paspartinti analizès skaičiavimus.

\subsubsection{Nuosekliosios sintezès būdas}

Šiuo etapu nėra išvesta tikslių matematinių išraiškų, siejančių DML elektrines charakteristikas ir jos konstrukcinius parametrus, todèl linijos sintezè gali būti tik iteracinio pobūdžio (Martavičius et al. 2000).

Nuosekliai atliekant analizès operacijas tenka iš eilès nustatytu žingsniu keisti DML konstrukcinius parametrus ir skaičiuoti jos elektrines charakteristikas tol, kol gautų charakteristikų vertės skirsis nuo užsiduotų mažiau už nurodytą leistiną nuokrypį. Sintezuojant DML tokiu būdu tenka vidutiniškai perrinkti pusę konstrukcinių parametrų galimų verčių, taigi, projektavimo procesas užtrunka ilgai.

DML sintezès trukmė gali būti ženkliai sumažinta pritaikius konstrukcinių parametrų parinkimui optimalios paieškos metodus, pvz., skiltinio artẻjimo (Neapolitan et al. 2004). Šiuo atveju sintezė prasideda nuo DML pradinių ir ribinių konstrukcinių ir elektriniu parametru nustatymo. DML analizè atliekama BS metodu taikant (3.6)-(3.8) išraiškas ir, suradus potencialo pasiskirstymą, apskaičiuojamas DML charakteringasis impedansas bei efektyvioji dielektrinè skvarba. Nuosekliosios DML sintezės atveju, skiltinio artejimo algoritmas taikytinas mikrojuostelès pločio $W$ ir tarpo tarp mikrojuostelių $S$, užtikrinančių siekiamus charakteringaji impedansą ir efektinę skvarbą, paieškai. Vykdant mikrojuostelès pločio paiešką imama vidurinè ruožo reikšmė:

$$
W_{\mathrm{vid}}=\frac{W_{\max }-W_{\min }}{2},
$$

čia $W_{\min }$ - mažiausias leistinas mikrojuostelès plotis; $W_{\max }$ - didžiausias leistinas mikrojuostelès plotis.

Jei apskaičiuoto ir ieškomo charakteringojo impedanso skirtumas didesnis už leistiną nuokrypi, tai nustatoma nauja mikrojuostelès pločio mažiausia riba, kuri lygi analizès gardelès vertei vienu žingsniu didesnei nei pagal (3.90) apskaičiuota vidurinè vertė: $W_{\min }=W_{\text {vid }}+1$. Kitu atveju, jei apsikačiuoto ir ieškomo impedanso skirtumas viršija nustatytą paklaidą ir yra neigiamas, nustatoma didžiausia riba, kuri lygi pagal (3.9) apskaičiuotai vidurinei vertei 
$W_{\max }=W_{\text {vid }}$. Nuosekliuoju būdu sintezuojant DML keičiamas mikrojuostelès plotis ir tarpas tarp mikrojuostelių kiekvienai užduotai pagrindo dielektrinès skvarbos vertei. Iš gautų charakteringųjų impedansų randama artimiausia charakteringo impedanso reikšmè siekiamai vertei.

\subsubsection{Lygiagrečiosios sintezès būdas}

Paskirstę analizès uždavinius tarp daugelio kompiuterių t. y. analizę atliekant lygiagrečiai, galima žymiai paspartinti DML projektavimo procesą. Siūlomo lygiagrečiojo sintezès algoritmo blokinè schema pateikta 3.6 pav. Tarkime, kompiuterių telkini sudaro vienas vedantysis kompiuteris ir $p-1$ pavaldžiųjų kompiuterių (telkinio mazgų). Algoritmas atliekamas per 16 žingsnių:

1. Nustatomi pradiniai konstrukciniai ir elektriniai parametrai reikalingi DML sintezei: dielektrinio pagrindo storis $h$ ir dielektrinè skvarba $\varepsilon_{\mathrm{r}}$, mikrojuostelès pločio pradinè $W_{\min }$ ir ribinè $W_{\max }$ vertès, tarpo tarp mikrojuostelių pradine $S_{\min }$ ir ribinè $S_{\max }$ vertès, analizuojamos srities pradiniai potencialai, siekiamo charakteringojo impedanso $Z_{0}$ nominali vertè bei leistinas nuokrypis nuo jos $\delta$, analizuojamos srities gardelès žingsnių $\Delta W$ ir $\Delta S$ vertès.

2. Kompiuterių telkinio valdantysis mazgas persiunčia nustatytus pradinius elektrinius ir konstrukcinius parametrus pavaldiesiems telkinio mazgams.

3. Kiekvienas $i$-asis pavaldusis mazgas apsiskaičiuoja jam skirtu mikrojuostelès pločių ruožą $\Delta W_{i}=\left(W_{\max }-W_{\min }+1\right) / p$, kuriame analizès metu (3.6 pav. pateiktoje schemoje lygiagretieji 4.1-4. $p$ blokai) skaičiuos DML elektrinius parametrus. Čia $p$ - pavaldžiųjų mazgų skaičius kompiuterių telkinyje.

4. Kiekvienas pavaldusis mazgas atlieka DML analizę baigtinių skirtumų metodu pagal (3.6)-(3.8) išraiškas ir apskaičiuoja DML charakteringaji impedansą $Z_{0 i}$ ir efektyviają dielektrinę skvarbą $\varepsilon_{\text {ref } i}$.

5. Ketvirto žingsnio analizė kartojama kol bus apskaičiuotos visos $i$-tajam pavaldžiajam mazgui skirtos mikrojuostelés pločio vertės $\Delta W_{i}$ ruože.

6. Apskaičiuoti rezultatai $Z_{0 i}\left(\Delta W_{i}\right)$ ir $\varepsilon_{\text {refi }}\left(\Delta W_{i}\right)$ surūšiuojami kiekvieno pavaldžiojo mazgo ir persiunčiami valdančiajam mazgui. 


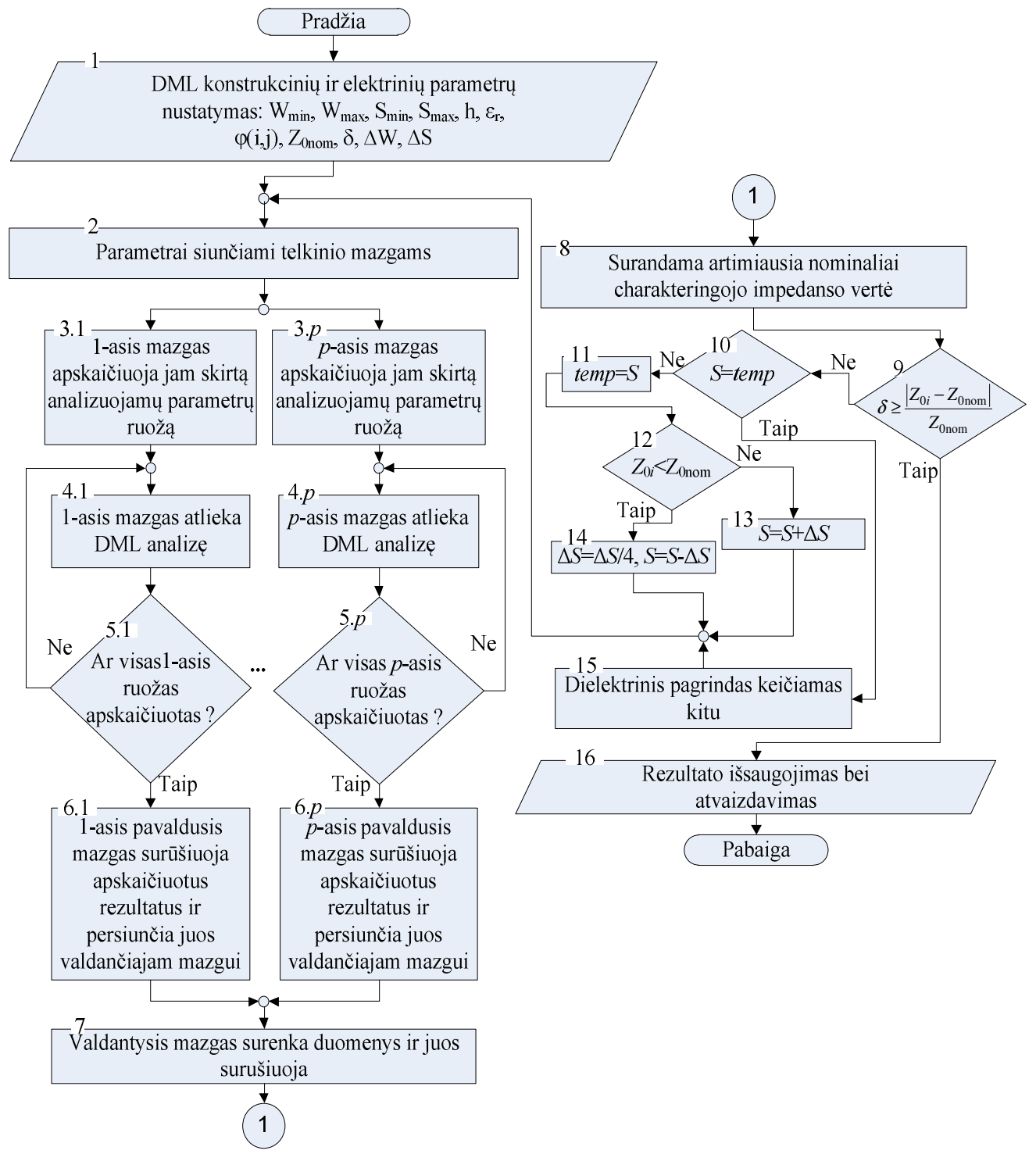

3.6 pav. Daugialaidės mikrojuostelinès linijos lygiagretusis sintezės algoritmas Fig. 3.6. Parallel algorithm of the synthesis of multiconductor microstrip lines 
7. Gautus rezultatus $Z_{0 i}\left(\Delta W_{i}\right)$ ir $\varepsilon_{\text {ref } i}\left(\Delta W_{i}\right)$ valdantysis mazgas surūšiuoja pavaldžiụjų mazgų $i$ eilès tvarka ị vienmačius masyvus $\left[Z_{0 i}(W)\right]$ ir $\left[\varepsilon_{\mathrm{r} \text { ef } i}(W)\right]$.

8. Masyve $\left[Z_{0 i}(W)\right]$ ieškoma vertès $Z_{0 i}$ artimiausiosios nominaliajai $Z_{0 \text { nom }}$ vertei.

9. Tikrinama, ar surastosios artimiausiosios ir nominaliosios charakteringojo impedanso verčiu santykinis skirtumas neviršija leistino nuokrypio

$$
\delta \geq \frac{Z_{0 i}-Z_{0 \text { nom }}}{Z_{0 \text { nom }}} .
$$

Jeigu (3.10) lygybė tenkinama, pereinama ties 16 žingsniu. Jeigu netenkinama - pereinama ties 10 žingsniu.

10. Tikrinama, ar tarpo tarp mikrojuostelių vertè $S$ nebuvo panaudota skaičiavimuose. Tikrinant pirmą kartą laikinojo kintamojo temp vertẻ lygi 0 . Jeigu $S$ vertè nesikartoja, pereinama ties 11 žingsniu. Jeigu esama $S$ vertė jau buvo taikoma - pereinama ties 15 žingsniu.

11. Naudota tarpo tarp mikrojuostelių $S$ vertè priskiriama laikinajam kintamajam temp.

12. Šiuo žingsniu pagal rastą artimiausiają charakteringojo impedanso vertę $Z_{0 i}$ nustatoma tolimesnè sintezès kryptis. Jeigu $Z_{0 i}<Z_{0}$, siekiant padidinti DML impedansą, $S$ turi būti sumažintas - pereinama ties 13 žingsniu ir, atitinkamai, jeigu $Z_{0 i}>Z_{0}$, tuomet $S$ turi būti padidintas, taigi, pereinama ties 14 žingsniu.

13. Tarpas tarp laidininkų padidinamas $S=S+\Delta S$ ir grižtama ties 2 žingsniu.

14. Mažinami atitinkamai žingsnis $\Delta S=\Delta S / 4$ ir tarpas tarp laidininkų $S=S-\Delta S$. Grịžtama ties 2 žingsniu.

15. Išmėginus visas leistinas $S$ vertes tarp $S_{\min }$ ir $S_{\max }$, ir negavus siekiamo charakteringojo impedanso, pasirenkama kita dielektrinio pagrindo skvarba $\varepsilon_{\mathrm{r}}$ ir pereinama ties 2 žingsniu.

16. Apskaičiuoti sintezès rezultatai išsaugojami ir vaizduojami monitoriaus ekrane. 


\subsubsection{Sintezès algoritmo patikra}

Pasiūlytas lygiagretusis sintezès algoritmas buvo išbandytas 16-kos kompiuteriu heterogeniniame telkinyje (kompiuterio CPI - Intel ${ }^{\circledR}$ Pentium $^{\circledR} 2,6 \mathrm{GHz}$ ir Intel ${ }^{\circledR}$ Pentium $^{\circledR} 2,8 \mathrm{GHz}$, operatyviosios atminties talpa atitinkamai $512 \mathrm{MB}$ ir $1 \mathrm{~GB}$, standžiojo kietojo disko talpa atitinkamai $40 \mathrm{~GB}$ ir $80 \mathrm{~GB}$; operaciné sistema - Fedora 6, kompiuterių tinklas - Ethernet $100 \mathrm{Mb} / \mathrm{s}$ ).

Pirmuoju etapu buvo patikrinta DML sintezès nuokrypis nuo nominalių verčių. Iš esmès DML sintezès tikslumą lemia pasirinktas analizès metodas (mūsų atveju BS metodas), sudarytas DML matematinis modelis ir jo parametrai.

Siūlomo algoritmo tikslumui patikrinti buvo susintezuotos trys DML, kurių nominalios charakteringojo impedanso vertès yra atitinkamai $50 \Omega, 75 \Omega$ ir $120 \Omega$. Pagal susintezuotų DML konstrukcinius parametrus buvo atlikta šių linijų analizė momentų metodu. Bandomosios DML sintezès ir analizès rezultatai pateikti 3.3 lentelèje.

3.3 lentelè. Lygiagrečiosios DML sintezès patikros rezultatai

Table 3.3. Results of parallel synthesis of the multiconductor microstrip lines

\begin{tabular}{|c|c|c|c|}
\hline \multirow{2}{*}{$\begin{array}{c}\text { Sintezuotụ DML } \\
\text { konstrukciniai parametrai }\end{array}$} & \multicolumn{3}{|c|}{$\begin{array}{c}\text { Nominali charakteringojo } \\
\text { impedanso verte், } \Omega\end{array}$} \\
\cline { 2 - 4 } & 50 & 75 & 120 \\
\hline$W / h$ & 2,2 & 1,15 & 0,45 \\
\hline$S / h$ & 1,0 & 1,1 & 1,1 \\
\hline$\varepsilon_{\mathrm{r}}$ & 6,0 & 6,0 & 6,0 \\
\hline $\begin{array}{c}\text { Sintezès metu pasiektas charakte- } \\
\text { ringasis impedansas, } \Omega\end{array}$ & 50,34 & 74,36 & 119,97 \\
\hline Sintezés paklaida, \% & 0,68 & $-0,85$ & $-0,025$ \\
\hline $\begin{array}{c}\text { Momentu metodu apskaičiuotas } \\
\text { charakteringasis impedansas, } \Omega\end{array}$ & 51,9 & 78,7 & 125,5 \\
\hline $\begin{array}{c}\text { Santykinis impedansu, apskaičiuotų } \\
\text { skirtingais metodais, skirtumas, \% }\end{array}$ & 3,1 & 5,84 & 4,61 \\
\hline
\end{tabular}

Pagal 3.3 lenteleje pateiktus duomenis matyti, kad lygiagrečiojo algoritmo sintezès nuokrypis neviršija $1 \%$. Leistinas charakteringojo impedanso sintezès nuokrypis taip pat buvo nustatytas $\delta_{Z} \leq 1 \%$. Skirtingais metodais gautos charakteringojo impedanso vertès skiriasi mažiau nei $6 \%$. Ši skirtumą galima paaiškinti BS ir momentų metoduose naudojamų DML modelių skirtumu. DML analizuojant baigtiniais skirtumais daroma prielaida, kad linija yra periodinè 
skersiniame pjūvyje. Momentu metodo atveju linija yra baigtinio dydžio. 3.3 lentelèje pateiktos momentų metodu apskaičiuotos charakteringojo impedanso vertès atitinka centrinę mikrojuostelę vienuolikos mikrojuostelių DML. Ši charakteringojo impedanso skirtumą galimą šiek tiek sumažinti didinant siūlomame algoritme analizuojamą sritị ir mažinant gardelès žingsnį, tačiau sintezè tokiu atveju užtruks žymiai ilgiau. Tuo tarpu minètas mažesnis negu $6 \%$ metodu, skirtumas yra priimtinas inžinerinèje praktikoje (Urbanavičius et al. 2006).

İsitikinus DML sintezès tikslumu antruoju etapu buvo ištirta siūlomo lygiagrečiojo algoritmo vykdymo trukmè ir spartinimo koeficientas.

Algoritmo efektyvumo tyrimo rezultatai pateikti 3.7 pav. Tyrimo metu parinktas DML mikrojuosteliu pločių diapazonas $W_{\max }-W_{\min }=60$ gardelès žingsnių, tarpų tarp laidininkų diapazonas $S_{\max }-S_{\min }=50$ gardelès žingsnių, sintezuojant DML leista pasirinkti vieną iš 3 dielektrikų tipų (1-ojo tipo dielektrinis pagrindas, $\varepsilon_{\mathrm{r}}=6,0 ; 2$-ojo tipo pagrindas, $\varepsilon_{\mathrm{r}}=9,8 ; 3$-ojo tipo pagrindas $\varepsilon_{\mathrm{r}}=16,0$ ), kompiuteriu skaičius telkinyje buvo didinamas nuo 1 iki 16 (vienas iš mazgų yra valdantysis kompiuteris, kiti nuo 1 iki 15 - pavaldieji).

Algoritmo efektyvumo tyrimo rezultatai pateikti 3.7 pav. Tyrimo metu parinktas DML mikrojuostelių pločių diapazonas $W_{\max }-W_{\min }=60$ gardelès žingsnių, tarpų tarp laidininkų diapazonas $S_{\max }-S_{\min }=50$ gardelès žingsnių, sintezuojant DML leista pasirinkti vieną iš 3 dielektrikų tipų (1-ojo tipo dielektrinis pagrindas, $\varepsilon_{\mathrm{r}}=6,0 ; 2$-ojo tipo pagrindas, $\varepsilon_{\mathrm{r}}=9,8 ; 3$-ojo tipo pagrindas $\varepsilon_{\mathrm{r}}=16,0$ ), kompiuteriu skaičius telkinyje buvo didinamas nuo 1 iki 16 (vienas iš mazgų yra valdantysis kompiuteris, kiti nuo 1 iki 15 - pavaldieji).

3.7 pav. matyti, kad didinant mazgų skaičių kompiuterių telkinyje, DML sintezès trukmė proporcingai mažèja, atitinkamai didejja algoritmo spartinimo koeficientas. Taip pat matyti, kad didinant mazgų skaičių kompiuterių telkinyje, spartinimo koeficientas didejja tiesiškai ir dar neturi asimptotinio darbo režimo požymių. Esant 15 mazgų kompiuterių telkinyje spartinimo koeficiento vertè šiek tiek labiau padidejja, tai galima paaiškinti tuo, kad naudojamas heterogeninis kompiuterių telkinys ir pridedant mazgų $\mathrm{MPICH} 2$ programine įranga pateikia daugiau užduočių spartesniems mazgams negu lètesniems. 

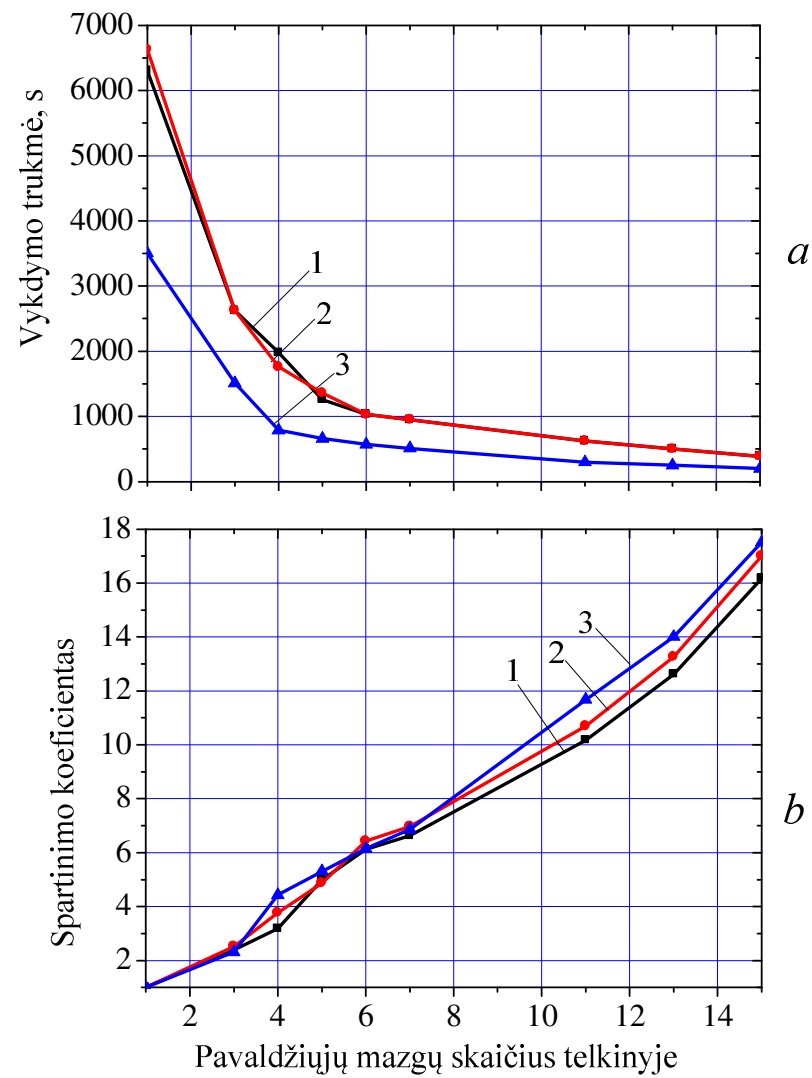

3.7. pav. Lygiagrečiojo DML sintezès algoritmo veikimo trukmès $(a)$ ir spartinimo koeficiento $(b)$ priklausomybès nuo pavaldžiujų mazgų skaičiaus kompiuterių telkinyje,

$$
\text { kai } 1-Z_{0}=50 \Omega, 2-Z_{0}=75 \Omega \text { ir } 3-Z_{0}=120 \Omega
$$

Fig. 3.7. Execution time ( $a$ ) and speedup coefficient $(b)$ of the parallel algorithms versus number of cluster nodes, where $1-Z_{0}=50 \Omega, 2-Z_{0}=75 \Omega$ and $3-Z_{0}=120 \Omega$

Padidinus pavaldžiųjų mazgų skaičių virš 15 , sintezès uždavinys gali būti dar labiau paspartintas, nes esant 15 mazgams kiekvienam iš jų tenka analizuoti 4 skirtingus $W_{\max }-W_{\min }$ intervalus. Pridedant naujų mazgų kompiuterių telkinyje analizuojamų $W_{\max }-W_{\min }$ skaičius kiekviename mazge mažès ir spartinimo koeficientas tūrètų didèti. Kai $W_{\max }-W_{\min }=60$ gardelès žingsnių, pavaldžiųjų mazgų daugiausia gali būti 60 . 


\subsection{Trečiojo skyriaus išvados}

1. Pasiūlytas ir ịgyvendintas užduoties lygiagretinimo principu grịstas lygiagretusis daugialaidžių mikrojuostelinių linijų (DML) analizès algoritmas. Pažymètina, kad šis algoritmas gali būti ịgyvendintas $2^{n}+1$ kompiuterių telkinyje, čia $n$ - DML sužadinimo būdų, atitinkančių tam tikrą normaliujų bangų darbo režimą, skaičius.

2. Lygiagrečiajame analizès algoritme taikytinas bet koks DML matematinis modelis.

- Lygiagretusis DML, sužadinamos sinfaziškai arba priešfaziškai, analizès algoritmas, taikant baigtinių skirtumų metodu grịstą matematinị modelị, buvo igyvendintas penkių kompiuterių telkinyje.

- Analizuojamos DML srities potencialų radimui panaudotas mažiausių kvadratų tiesinių lygčių sprendimo metodas leidžia išvengti ilgai trunkančių iteracinių skaičiavimų.

- Siūlomas lygiagretusis algoritmas buvo patikrintas analizuojant 4-ių ir 5ių mikrojuostelių DML. Patikros rezultatai skyrèsi nuo literatūroje skelbiamų mažiau negu $3 \%$. Pasiūlytas algoritmas leidžia sumažinti DML analizès trukmę iki 3,6 karto.

3. Pasiūlytas ir ịgyvendintas duomenų lygiagretinimo principu grịstas lygiagretusis DML sintezès algoritmas. Pažymėtina, kad:

- Lygiagrečiajame DML sintezès algoritme, siekiant sumažinti analizuojamos srities dydị ir tokiu būdu paspartinti skaičiavimus, gali būti pritaikytas periodinès DML modelis.

- Lygiagretusis DML sintezès algoritmas igyvendintas 16 mazgų kompiuterių heterogeniniame telkinyje (kompiuterių CPI - Intel ${ }^{\circledR}$ Pentium $^{\circledR}$ 2,6 GHz ir Intel ${ }^{\circledR}$ Pentium ${ }^{\circledR} 2,8 \mathrm{GHz}$, operatyviosios atminties talpa atitinkamai $512 \mathrm{MB}$ ir $1 \mathrm{~GB}$, standžiųų diskų kaupiklio talpa atitinkamai 40 GB ir $80 \mathrm{~GB}$; operacinè sistema - Fedora 6, kompiuterių tinklas - Ethernet $100 \mathrm{Mb} / \mathrm{s})$.

- Tiriant igyvendintą lygiagretujj DML sintezès algoritmą nustatyta, kad sintezuotų DML charakteringasis impedansas skiriasi nuo nominalių verčių mažiau negu $1 \%$, o nuo impedanso, apskaičiuoto momentų metodu, mažiau negu $6 \%$. Charakteringojo impedanso verčių skirtumas sintezuo- 
tos DML ir nominalios gali būti sumažintas mažinant analizuojamos srities gardelès žingsnị.

- Igyvendinto lygiagrečiojo algoritmo efektyvumo tyrimo rezultatai parodé, kad DML sintezès trukmė mažèja didinant mazgų skaičių kompiuterių telkinyje ir, kai mazgų telkinyje buvo 16 DML sintezè truko vos 4 min. Sintezės trukmė gali būti mažinama didinant kompiuterių skaičių iki $N-$ keičiamų konstrukcinių parametrų didžiausio ruožo dydžio.

- Nustatyta, kad, kol mazgų skaičius $p$ kompiuterių telkinyje neviršija 16, lygiagrečiojo algoritmo spartinimo koeficientas $S_{p}$ didèja tiesiškai ir, kai $p=16, S_{p}=16,82$. Tiesinè spartinimo koeficiento priklausomybė rodo, kad asimptotinis darbo režimas dar nepasiektas ir tolimesnis mazgų skaičiaus telkinyje didinimas atitinkamai tūrètų mažinti sintezès trukmę. 


\section{4}

\section{Lygiagrečioji vèlinimo trukmès apskaičiavimo metodika}

Šiame skyriuje siūloma lygiagrečioji meandrinių mikrojuostelinių vèlinimo linijų (MMVL) vẻlinimo trukmės dažninès priklausomybès apskaičiavimo metodika. Ankstesniuose skyriuose buvo pateikti daugialaidžių mikrojuostelinių linijų (DML) modeliai, kurių analizès parametrai naudojami modeliuojant MMVL. Pirmame poskyryje aptariami MMVL analizès principai. Antrame išnagrinėti dispersinès lygties skaitinio sprendimo algoritmai. Trečiame poskyryje pristatyta lygiagrečioji MMVL analizès metodika, o ketvirtame - pateikti igyvendintos metodikos tyrimo rezultatai.

Skyriaus tematika paskelbti du autoriaus straipsniai (Pomarnacki et al. 2009; Pomarnacki 2010).

\subsection{Meandrinių mikrojuostelinių vèlinimo linijų analizè}

Supaprastintas MMVL konstrukcijos pavyzdys pateiktas 4.1 pav. Pagrindiniai MMVL elektriniai parametrai ir charakteristikos yra šie: vẻlinimo trukmé 
esant žemiesiems dažniams $t_{\mathrm{v}}$, charakteringasis impedansas esant žemiesiems dažniams $Z_{0}$, praleidžiamųjų dažnių juosta $\Delta F$, vèlinimo trukmės priklausomybė nuo dažnio $t_{\mathrm{v}}(f)$ ir charakteringojo impedanso priklausomybė nuo dažnio $Z_{0}(f)$. Vèlinimo trukmès priklausomybė nuo dažnio nustatoma iš atitinkamos meandrinès lètinimo sistemos dispersinès charakteristikos - lètinimo koeficiento priklausomybè nuo dažnio:

$$
k_{\mathrm{L}}(f)=\frac{\theta}{\beta_{0} L}, \text { kai } f=\frac{\mathrm{c}_{0} \beta_{0}}{2 \pi},
$$

čia $\beta_{0}=\omega / \mathrm{c}_{0}$ - elektromagnetinès bangos fazès koeficientas vakuume; $\theta$ itampų tarp gretimų meandro mikrojuostelių fazių skirtumas; $L=W+S-$ meandro mikrojuostelių išdèstymo žingsnis; $c_{0}$ - elektromagnetinès bangos fazinis greitis vakuume.

$$
t_{\mathrm{v}}=\frac{L \cdot N-S}{c_{0}} \cdot k_{\mathrm{L}}(f),
$$

čia $N$ - meandrinio laidininko pakopų skaičius analizuojamoje vèlinimo linijoje.

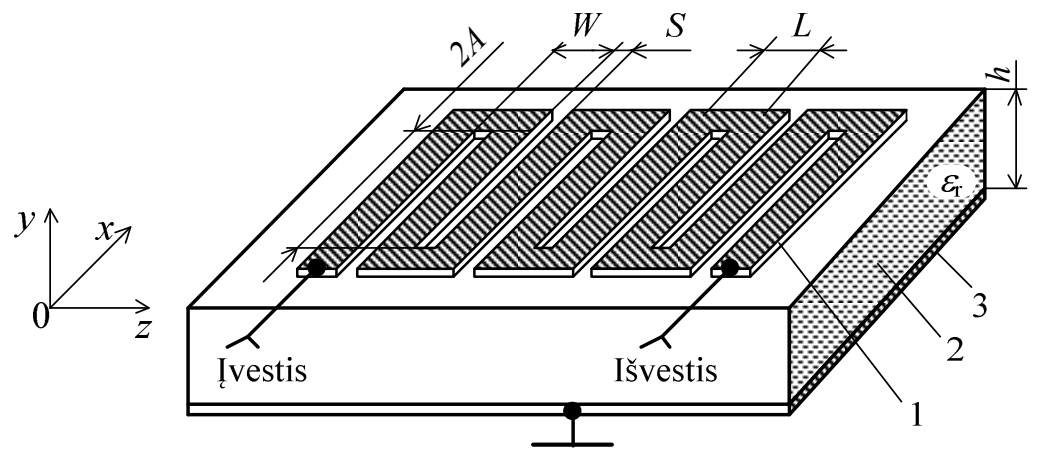

4.1 pav. Meandrinès mikrojuostelinės vèlinimo linijos konstrukcija: 1 - meandrinis mikrojuostelinis laidininkas; 2 - dielektrinis pagrindas; 3 - ištisinis ekranas

Fig. 4.1. Design of the meander microstrip delay line: 1 - meander microstrip conductor; 2 - dielectric substrate; 3 - shield 
MMVL dispersinė lygtis (Gurskas et al. 2010) apibūdina sąryšs tarp elektromagnetinès bangos fazès koeficientų vakuume ir nagrinejjamoje MMVL. Kiekvienam pasirinktam $\beta_{0}$ turi būti rasta atitinkama $\theta$ vertè, taigi, dispersinès lygties sprendinio paieškai tenka taikyti skaitinius metodus. Žinant $\beta_{0}$ ir $\theta$ vertes galima apskaičiuoti kitus MMVL elektrinius parametrus: fazès vèlinimo trukmę $t_{\mathrm{v}}$ ir charakteringajj impedansą $Z_{0}$.

Analizuojant MMVL, siekiama apskaičiuoti lètinimo koeficientą ir ịvesties impedansą. Šiuo atveju labai svarbu, tačiau ir labai sudètinga surasti funkciją $\theta=f\left(\beta_{0}\right)$. Šios problemos praktiškai neįmanoma išspręsti be kompiuterio. Todèl yra sukurta nemažai programų, skirtų apskaičiuoti MMVL lètinimo koeficiento ir charakteringojo impedanso dažnines charakteristikas (Gurskas et al. 2002). Tipinis tokios programos algoritmas pateiktas 4.2 pav.

Algoritmas gali būti išskaidytas ị dvi dalis: DML, kurios skersiniai konstrukciniai parametrai atitinka analizuojamą MMVL, elektrinių parametrų apskaičiavimas, esant lyginiam ir nelyginiam DML sužadinimui (1 ir 2 žingsniai); ir MMVL dažninių charakteristikų apskaičiavimas (3-7 žingsniai).

MMVL dispersinę lygti galima išreikšti tokia forma (Гурскас 1991):

$$
D_{\mathrm{c}} D_{\pi}=0
$$

čia

$$
\begin{gathered}
D_{\mathrm{c}}=Y(\theta) \tan \left(\beta_{\mathrm{c}} A\right)-Y(\theta+\pi) \tan ^{2} \theta / 2, \\
D_{\pi}=Y(\theta) \cot \left(\beta_{\mathrm{c}} A\right)-Y(\theta+\pi) \tan \left(\beta_{\pi} A\right) \tan ^{2} \theta / 2,
\end{gathered}
$$

čia $Y(\theta)$ ir $Y(\theta+\pi), \quad \beta_{\mathrm{c}}=\omega / c_{0} \sqrt{\varepsilon_{\mathrm{r} \text { ef }}(\theta)}$ ir $\beta_{\pi}=\omega / c_{0} \sqrt{\varepsilon_{\mathrm{r} \text { ef }}(\theta+\pi)}$, $\varepsilon_{\text {r ef }}(\theta)$ ir $\varepsilon_{\text {r ef }}(\theta+\pi)$, bei $A$ - atitinkamai yra DML banginiai laidžiai, fazès koeficientai ir santykinès efektyviosios dielektrinès skvarbos, esant lyginiam ir nelyginiam DML sužadinimui, ir MMVL meandro aukštis. MMVL dispersinès lygties sprendinio paieškai taikytini funkcijos ekstremumo paieškos metodai. Funkcijos (4.3) ekstremumo paieška yra daugiažingsnis procesas, todèl 4.2 pav. pateikto algoritmo 4 žingsnis reikalauja daug laiko resursų. Tai tampa ypač aktualu sintezuojant MMVL konstrukciją. 


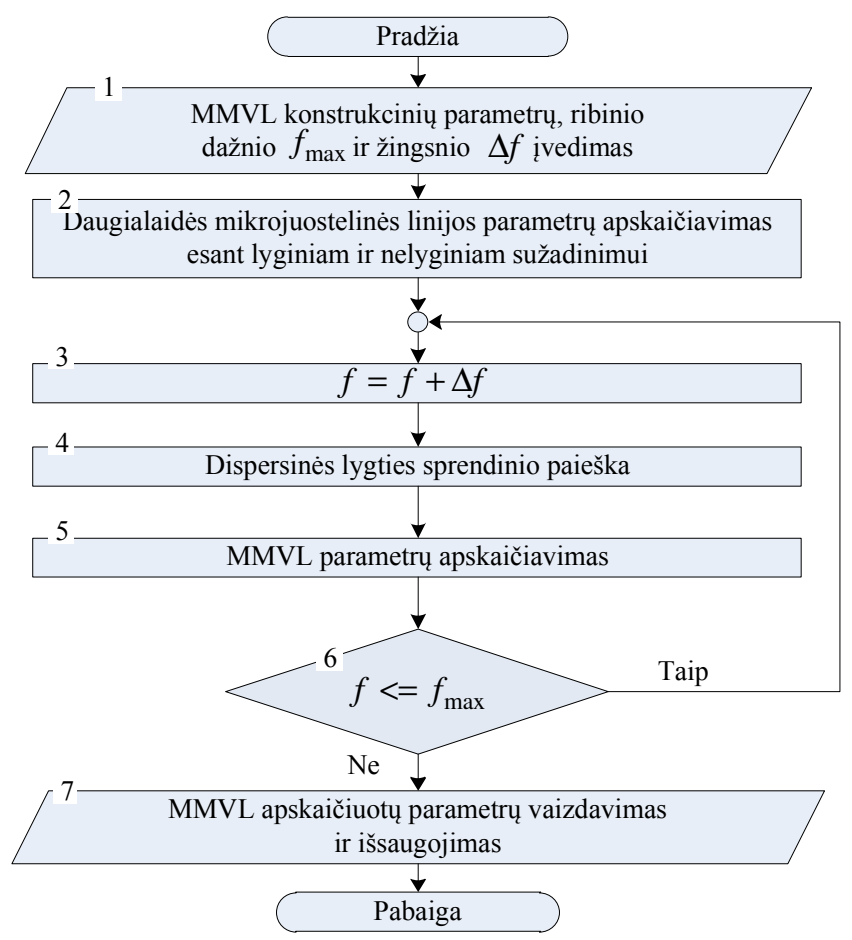

4.2 pav. Tipinis MMVL dažninių charakteristikų apskaičiavimo algoritmas Fig. 4.2. Typical algorithm of MDML frequency characteristics calculation

Dispersinès lygties (4.3) sprendinių pasiskirstymui surasti reikia lygtị šiek tiek pertvarkyti - jos kairiają pusę perkelti ị dešinę ir perrašyti funkcijos pavidalu. Šios funkcijos argumento vertė atitiks ieškomą lygties sprendini, kai pati funkcija lygi nuliui:

$$
g(\theta)=D_{\mathrm{c}} D_{\pi}=0 .
$$

Sprendžiant (4.6) lygtị turi būti pasirinktas dažnis $f=$ const, o fazès vertė $\theta$ yra keičiama. Tokio skaičiavimo rezultato pavyzdys pateiktas 4.3 pav. 


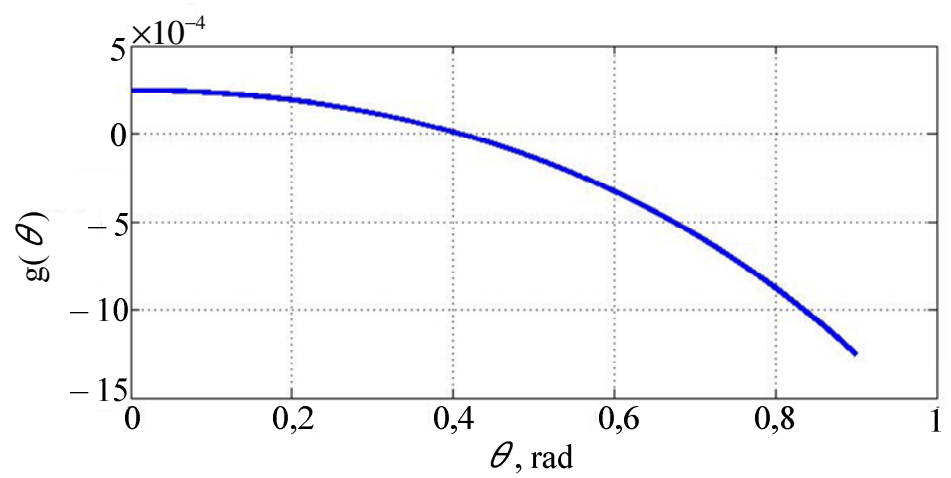

4.3 pav. Dispersinès lygties sprendinio verčių pasiskirstymas

Fig. 4.3. Results of the dispersion equation solution

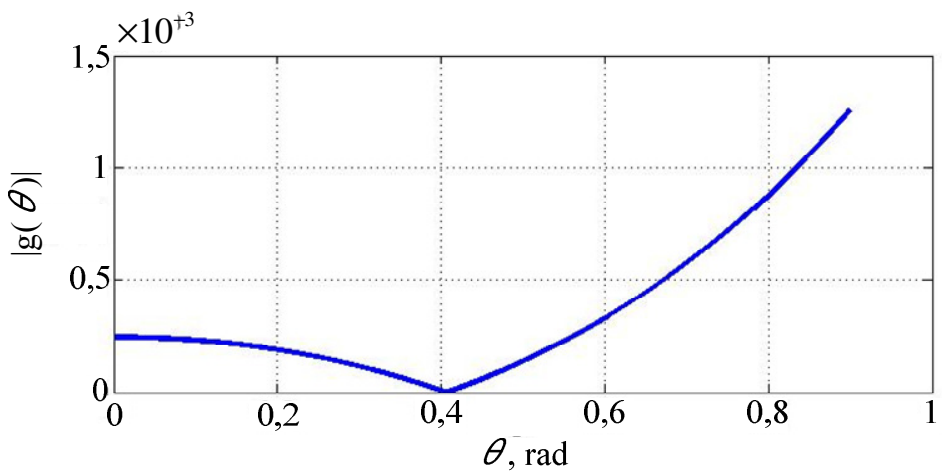

4.4 pav. Dispersinès lygties sprendinio absoliučiosios vertès Fig. 4.4. Absolute values of the dispersion equation solution

4.3 pav. matyti, kad didèjant fazei $\theta$, funkcijos (4.6) vertès kinta iš teigiamų i neigiamas, kertant nulinị lygị. Pakeitus funkcijos (4.6) vertes absoliučiomis, gaunamas 4.4 pav. pateiktas grafikas.

Iš 4.4 pav. matyti, kad dispersinès lygties funkcija (4.6) visada turi nuliui lygų sprendinį. Taigi, dispersinès lygties sprendimui galima naudoti funkcijos ekstremumo paieškos metodus. Kuriant lygiagrečiają MMVL vėlinimo trukmès apskaičiavimo metodiką buvo ịgyvendinti ir išbandyti keturi, dispersinès lygties sprendinio paieškai taikytini metodai: skiltinio artėjimo, ,dichotominis“, ,auksinio pjūvio“ ir „stygu““ metodai (Teukolsky 1999; Kelley 1999; Вержбицкий 2001). Nagrinėjant šiuos metodus kaip ịvesties duomenys taikomi MMVL pa- 
rametrai, kurie apskaičiuoti taikant analogiškos konstrukcijos DML modelį: charakteringasis impedansas esant lyginiam ir nelyginiam daugialaidès linijos sužadinimui $Z_{0 \mathrm{~L}, \mathrm{~N}}$. Dispersinės lygties sprendinio paieškai taip pat reikia ịvesti meandrinio laidininko aukštį $2 A$ (4.1 pav.) ir analizuojamo dažnio vertę $f$.

\subsection{Dispersinès lygties sprendimo algoritmai}

Šiame poskyryje pateiksime skiltinio artėjimo, „dichotominį“, ,auksinio pjūvio“ ir "stygų“ metodais grịstus dispersinès lygties sprendinio paieškos algoritmus.

Pirmasis dispersinès lygties sprendimo algoritmas, grịstas skiltinio artejjimo metodu (Teukolsky 1999), pateiktas 4.5 pav. Algoritmą sudaro 6 žingsniai:

1. Ivedami DML charakteringasis impedansas esant lyginiam ir nelyginiam linijos sužadinimui $Z_{0 \mathrm{~L}, \mathrm{~N}}$, pradinè fazès vertė $\theta_{0}$, fazės kitimo žingsnis $\Delta \theta$, meandrinio laidininko aukštis $2 A$ ir analizuojamo dažnio vertė $f$, didžiausia leistina skaičiavimų paklaida $\delta$. Pažymėtina, kad visuose nagrinejjamuose algoritmuose iš esmès taikomi tie patys pradiniai duomenys, taigi, kituose algoritmų aprašymuose jų nebevardinsime.

2. Apskaičiuojama dispersine lygtis $g\left(\theta_{0}\right)=D_{c} D_{\pi}$. Nustatoma kad $G=g\left(\theta_{n}\right)$, apskaičiuojama sekanti fazès vertè $\theta_{n+1}=\theta_{n}+\Delta \theta$, o taip pat apskaičiuojama sekanti dispersinès lygties vertė $g\left(\theta_{n+1}\right)=g\left(\theta_{n}\right)$.

3. Tikrinama sąlyga $G<g\left(\theta_{n+1}\right)$. Jeigu sąlyga yra tenkinama - grịžtama ties 2-uoju žingsniu, jeigu netenkinama - pereinama ties 4-uoju žingsniu.

4. Tikrinama sąlyga $|\Delta \theta|>\delta / 4$, čia $\delta$ - leistinas skaičiavimų nuokrypis. Jeigu sąlyga tenkinama - pereinama ties 5-uoju žingsniu, jeigu netenkinama - pereinama ties 6-uoju žingsniu.

5. Apskaičiuojamas mažesnis fazès kitimo žingsnis $\Delta \theta=-\Delta \theta / 4$ ir grịžtama ties 2-uoju žingsniu, taip kartojant paiešką.

6. Rezultato paieška yra sustabdoma ir rezultatas $\theta(f)$ yra išsaugojamas ir vaizduojamas. 


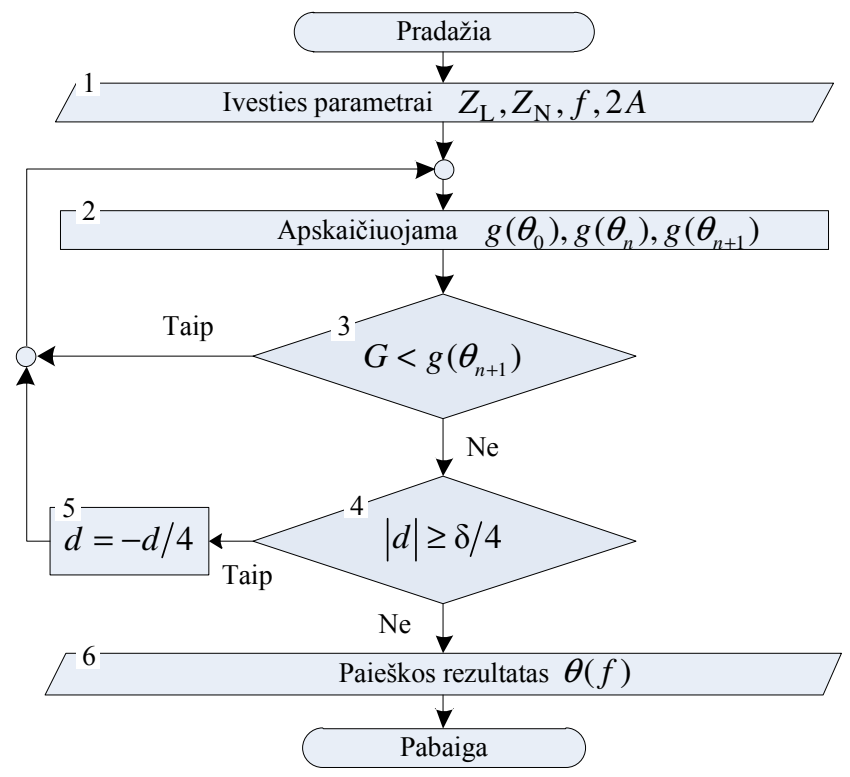

4.5 pav. Skiltinio artejimo metodu grịstas dispersinès lygties sprendimo algoritmas Fig. 4.5. Dispersion equation solving algorithm based on the consecutive approach search method

Antrasis dispersinès lygties sprendimo, grịstas „dichotominiu“ metodu (Teukolsky 1999). Pagal ši metodą privaloma nurodyti dispersinès lygties sprendinio paieškos ribas $[b-a]$. Algoritmas pateiktas 4.6 pav., ji sudaro 8 žingsniai:

1. Ivedami pradiniai DML parametrai, o taip pat papildomai ịvedama dispersinès lygties sprendinio paieškos riba $[b-a]$.

2. Tikrinama sąlyga $[b-a]<2 \delta$. Jeigu sąlyga tenkinama - pereinama ties 8 žingsniu, jeigu sąlyga netenkinama pereinama ties 3-uoju žingsniu.

3. Paieškos ruožas $[b-a]$ dalinamas pusiau ir apskaičiuojamos dvi papildomos $\theta_{1}$ ir $\theta_{2}$ vertès, $\theta=(b+a) / 2$ vertès atžvilgiu: $\theta=(b+a+\delta) / 2$ ir $\theta=(b+a-\delta) / 2$.

4. Pagal gautas $\theta_{1}$ ir $\theta_{2}$ atitinkamai apskaičiuojamos dispersinès lygties $g\left(\theta_{1}\right)$ ir $g\left(\theta_{2}\right)$ vertès.

5. Tikrinama sąlyga $g\left(\theta_{1}\right)>g\left(\theta_{2}\right)$. 


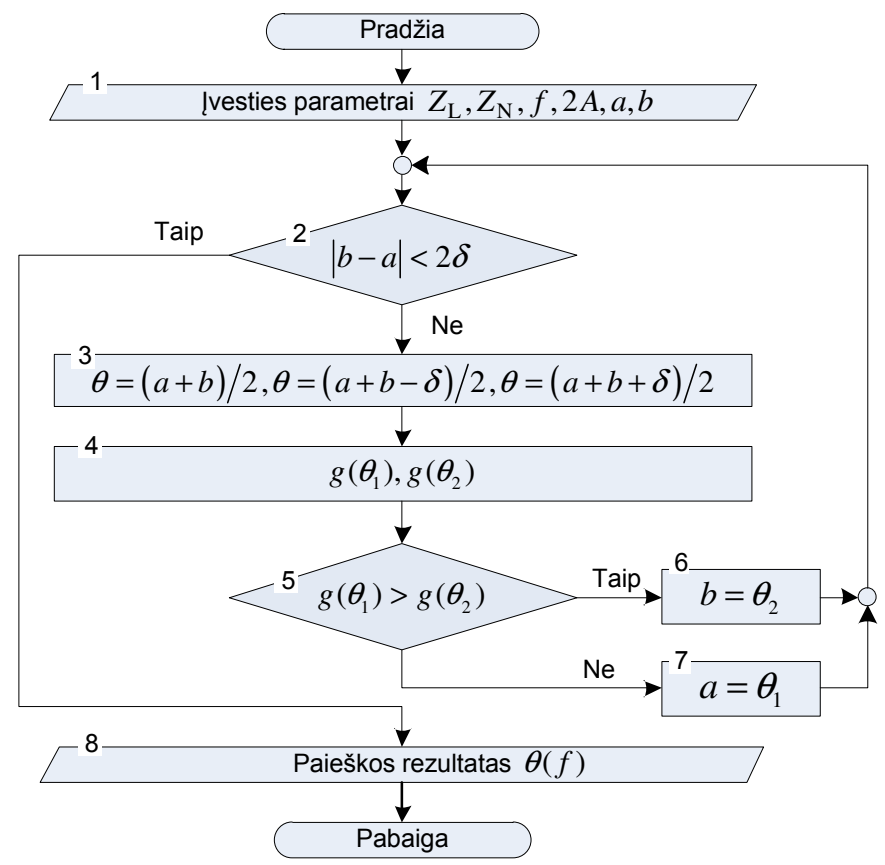

4.6 pav. „Dichotominiu“ metodu grịstas dispersinès lygties sprendimo algoritmas Fig. 4.6. Dispersion equation solving algorithm based on the dichotomies search method

6. Jeigu sąlyga 5-ame žingsnyje tenkinama - priskiriama $b=\theta_{2}$ ir grịžtama ties 2-uoju žingsniu.

7. Jeigu sąlyga 5-ame žingsnyje netenkinama - priskiriama $a=\theta_{2}$ ir grį̌ztama ties 2-uoju žingsniu.

8. Jeigu 2-ame žingsnyje sąlyga tenkinama, dispersinès lygties sprendinio paieška yra baigiama ir fazès vertè $\theta=(b-a) / 2$ yra išsaugojama ir vaizduojama.

Dispersinès lygties sprendimo, grịsto ,,auksinio pjūvio“ metodu (Teukolsky 1999), algoritmas pateiktas 4.7 pav.

Pagal ši metodą taip pat yra taikomas lygties sprendinio paieškos intervalas, kuris iteraciškai skaidomas pusiau. Šiuo atveju pagal „auksinio pjūvio“ metodą skaičiuojama tik viena dispersinès lygties funkcijos vertė intervalui $(b-a)$ nustatyti ir susiaurinti. Šio metodo algoritmą sudaro 7 žingsniai: 
1. Ivedami pradiniai DML parametrai, be to, apskaičiuojamas intervalo dalinimo koeficientas $k$.

2. Apskaičiuojamos pagalbinès vertès $\theta_{1}=a+(1-k)(b-a) \quad$ ir $\theta_{2}=a+k(b-a)$, bei šias vertes atitinkančias dvi dispersinès lygties funkcijos vertes $g\left(\theta_{1}\right)$ ir $g\left(\theta_{2}\right)$.

3. Tikrinama sąlyga $\left|\theta_{2}-\theta_{1}\right|<\delta$, jeigu ji tenkinama, tuomet apskaičiuojama fazès vertè $\theta=\left(\theta_{1}+\theta_{2}\right) / 2$ ir rezultatas yra vaizduojamas bei saugojamas ties 7-tuoju žingsniu. Jeigu sąlyga netenkinama - pereinama ties 4uoju žingsniu.

4. Tikrinama sąlyga $g\left(\theta_{1}\right)<g\left(\theta_{2}\right)$. Jeigu ji tenkinama - pereinama ties 5uoju žingsniu. Jeigu tenkinama kita sąlyga t. y. $g\left(\theta_{1}\right) \geq g\left(\theta_{2}\right)$ - pereinama ties 6-uoju žingsniu.

5. Priskiriamos naujos vertės $a=\theta_{1}, \theta_{1}=\theta_{2}, g\left(\theta_{1}\right)=g\left(\theta_{2}\right)$ ir pereinama ties 2-uoju žingsniu.

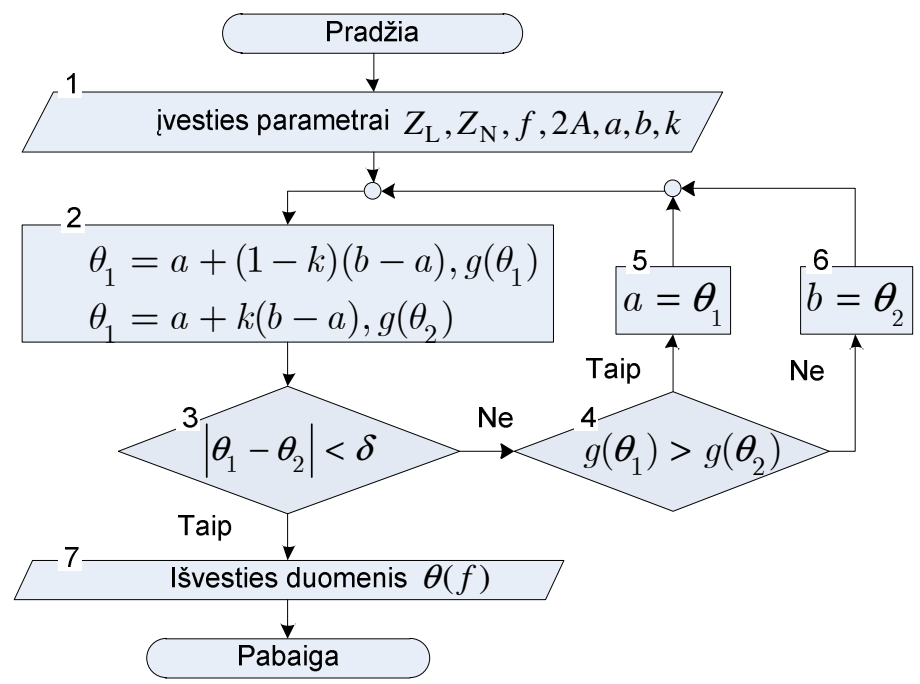

4.7 pav. „Auksinio pjūvio“ metodu grịstas dispersinès lygties sprendimo algoritmas Fig. 4.7. Dispersion equation solving algorithm based on the gold section search method 
6. Priskiriamos naujos vertès $b=\theta_{2}, \theta_{2}=\theta_{1}, g\left(\theta_{2}\right)=g\left(\theta_{1}\right)$ ir grị̌žtama ties 2-uoju žingsniu.

7. Vaizduojama ir išsaugojama apskaičiuota $\theta(f)$ vertè.

Paskutinysis iš aptariamų MMVL dispersinès lygties sprendimo metodų yra „stygu“ metodas (Вержбицкий 2001). Sis metodas panašus ị nuosekliojo artejjimo metodą, tačiau pagal ji dispersinès lygties funkcija (4.6) yra skaičiuojama du kartus. Panaudotos pradinès pasirinktosios fazès vertès ir apskaičiuotos pagal jas funkcijos vertès taikomos kitai fazès vertei apskaičiuoti. MMVL dispersinès lygties sprendimo algoritmą, pagal „stygu““ metodą sudaro 5 žingsniai (4.8 pav.):

1. Ivedami pradiniai MMVL analizès parametrai.

2. Algoritmą vykdant pirmą kartą $g\left(\theta_{0}\right)$ ir $g\left(\theta_{1}\right)$ apskaičiuojamos pagal priimtas pradines fazès vertes $\theta_{0}$ ir $\theta_{1}$. Algoritmą vykdant, kai $i \geq 2$, $g\left(\theta_{i-2}\right)$ ir $g\left(\theta_{i-1}\right)$ apskaičiuojamos pagal ankstesniuose cikluose gautas fazès vertes $\theta_{i-2}$ ir $\theta_{i-1}$.

3. Tikrinama sąlyga $g\left(\theta_{i-1}\right)<\delta$. Jeigu ji tenkinama - pereinama ties 5-uoju žingsniu, jeigu netenkinama - pereinama ties 4-uoju žingsniu.

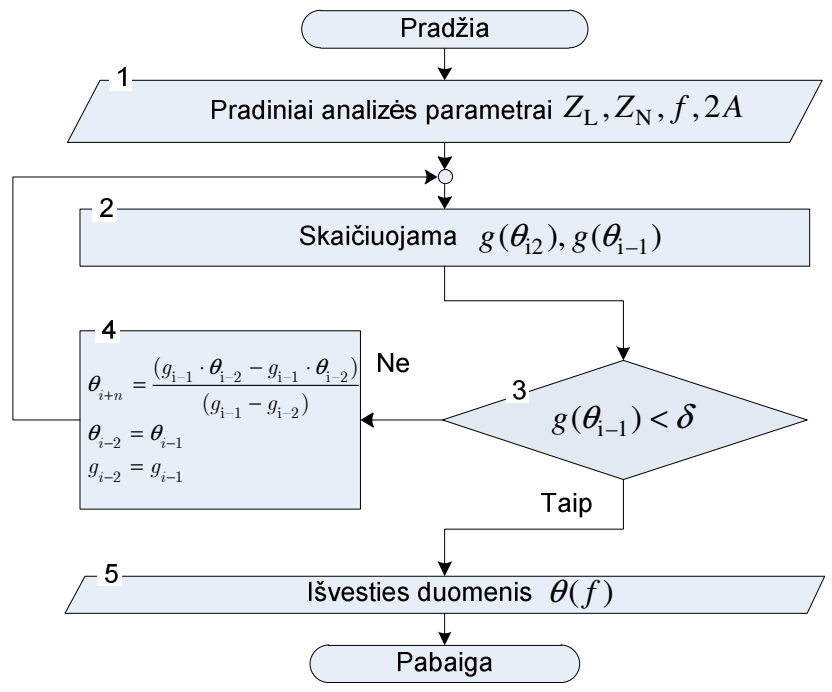

4.8 pav. „Stygu““ metodu grįstas dispersinès lygties sprendimo algoritmas

Fig. 4.8. Dispersion equation solving algorithm based on the chord search method 
4. Apskaičiuojama nauja fazès vertè pagal išraišką $g\left(\theta_{\mathrm{i}+\mathrm{n}}\right)=\left(f_{i-1} \cdot \theta_{i-2}-f_{i-2} \cdot \theta_{i-1}\right) /\left(f_{i-1}-f_{i-2}\right)$, be to priskiriamos naujos vertès $\theta_{i-2}=\theta_{i-1}, \theta_{i-1}=\theta_{i+n}$, bei $f_{i-2}=f_{i-1}$ ir grịžtama ties 2uoju žingsniu.

5. Apskaičiuota $\theta(f)$ vertė vaizduojama ir išsaugojama.

Nagrinėjant ịgyvendintų algoritmų veikimą pastebėta, kad dispersinès lygties sprendinio radimas konkrečiam dažniui trunka mažiau nei $10^{-6} \mathrm{~s}$ (kompiuterio CPI - Intel ${ }^{\circledR}$ Pentium $^{\circledR} 1,7 \mathrm{GHz}$, pagrindinès atminties talpa - $256 \mathrm{MB}$, standžiųuc diskų talpa - $40 \mathrm{~GB}$, operacinè sistema - Fedora 6) taigi, pagal kuri algoritmą lygtis sprendžiama sparčiau galima nustatyti tik analizuojant pakankamai platų dažnių ruožą. Šiuo tikslu visuose algoritmuose reikètų sudaryti for ciklą dažnio vertei keisti, bei išsaugoti kiekvieną apskaičiuotą vertę $\theta(f)$. Dispersinès lygties $10^{6}$ dažnio taškų skaičiavimo trukmès, taikant ịvairius ekstremumų paieškos algoritmus, pateiktos 4.1 lentelèje.

4.1 lentelè. Dispersinès lygties sprendinių paieškos algoritmų vykdymo trukmé*

Table 4.1. Execution time of algorithms of search of dispersion equation solutions*

\begin{tabular}{|l|l|}
\hline Paieškos metodas & Vykdymo trukmè, $\mathbf{s}$ \\
\hline Skiltinio artèjimo & 80,55 \\
\hline Dichotominis & 75,41 \\
\hline Auksinio pjūvio & 196,90 \\
\hline Stygų & 73,51 \\
\hline
\end{tabular}

* CPI - Intel ${ }^{\circledR}$ Pentium $^{\circledR} 1,7 \mathrm{GHz}$, pagrindinès atminties talpa - $256 \mathrm{MB}$, standžiųjų diskų talpa - $40 \mathrm{~GB}$, operacinè sistema - Fedora 6.

Iš 4.1 lentelès matyti, kad sparčiausias dispersinès lygties paieškos algoritmas yra algoritmas grịstas ,,stygų“ metodu. Jis beveik 2,6 karto spartesnis už ,auksinio pjūvio“ metodu grịstą algoritmą. 4.1 lentelèje taip pat matyti, kad dispersinès lygties sprendinio paieškos trukmė absoliučiu dydžiu, taikant îvairius ekstremumų paieškos algoritmus, nėra labai didelè ir vykdymo trukmès skirtumas, tarkime, tarp algoritmų, grịstų ,dichotominiu“ ir ,stygų“ metodais, sudaro vos 2,6 \%. Tačiau dar labiau padidinus analizuojamų dažnio taškų skaičių turètų atitinkamai išryškèti ir skirtumas tarp minètų algoritmų vykdymo trukmès. 


\subsection{Lygiagrečioji meandrinès mikrojuostelinès vèlinimo linijos analizès metodika}

Tikslioms MMVL charakteristikoms gauti jų analizė vykdoma plačiame dažnių ruože. Siekiant sumažinti skaičiavimo trukmę, racionalu būtų dispersinès lygties sprendinio dažnio taškus $f$ paskirstyti tarp kompiuterių telkinio mazgų. Šiuo atveju kiekvienas mazgas turètų lokalųji dažnio taškų intervalą $\Delta f_{i}$, kuriame būtų ieškomos fazès vẻlinimo trukmès ir apskaičiuojami kiti MMVL parametrai. Dispersinès lygties sprendimo kompiuterių telkinyje algoritmas pateiktas 4.9 pav.

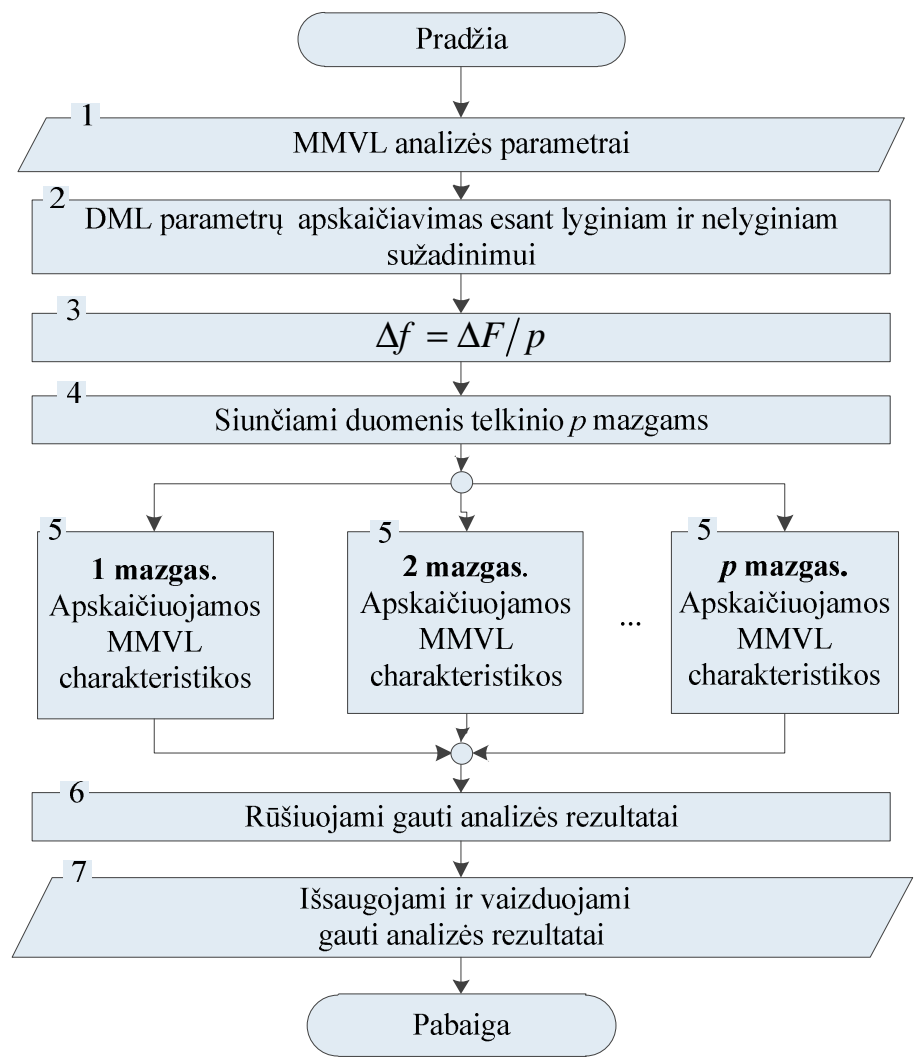

4.9 pav. Lygiagretusis MMVL dažninių charakteristikų apskaičiavimo algoritmas Fig. 4.9. Algorithm of calculation of frequency characteristics of MMDL using the parallel system 
Algoritme pritaikyta „valdantysis-pavaldusis“ (angl. master-slave) programavimo paradigma (Almeida 2004). Algoritmą sudaro 7 žingsniai:

1. Ivedami konstrukciniai MMVL parametrai: pagrindo dielektrinè skvarba $\varepsilon_{\mathrm{r}}$ ir jo storis $h$; meandro mikrojuostelių plotis $W$ ir tarpas tarp jų $S$; meandro mikrojuostelių aukštis $2 A$ ir nagrinėjamas dažnių intervalas $\Delta F$.

2. Apskaičiuojami DML elektriniai parametrai esant lyginiam ir nelyginiam linijos sužadinimui.

3. Analizuojamas dažnių intervalas $\Delta F$ dalinamas ị lokaliuosius dažnių intervalus $\Delta f=\Delta F / p$; čia $p$ - kompiuterių telkinio mazgų skaičius.

4. Kiekvieno lokaliojo dažnių intervalo $\Delta f_{i}$ pradžia, pabaiga ir dažnio žingsnis nusiunčiami kiekvienam telkinio mazgui.

5. Kiekviename mazge (pavaldžiajame kompiuteryje) atliekama dispersinès lygties sprendinio paieška ir fazès vèlinimo trukmès apskaičiavimas nurodytame lokaliajame dažnių ruože. Gaunami rezultatai yra išsaugojami ir persiunčiami valdančiajam mazgui. Šiuo žingsniu galima taikyti bet kuri iš anksčiau aptartų dispersinès lygties sprendinio paieškos metodų.

6. Valdantysis mazgas surūšiuoja iš pavaldžiųjų mazgų gautus analizès rezultatus atsižvelgiant ị analizuojamo dažnio intervalo $\Delta F$ vientisumą.

7. Visi apskaičiuoti MMVL analizès parametrai yra išsaugojami ir vaizduojami.

\subsection{Lygiagrečiosios meandrinių mikrojuostelinių vẻlinimo linijų dažninių charakteristikų apskaičiavimo metodikos tyrimas}

Siūloma lygiagrečioji metodika tirta dviem aspektais. Pirma, patikrintas MMVL matematinio modelio adekvatumas ir dispersinès lygties sprendimo tikslumas. Antra, ištirtas lygiagrečiojo MMVL dažninių charakteristikų apskaičiavimo algoritmo efektyvumas.

Tikrinant MMVL matematinio modelio adekvatumą ir dispersinès lygties sprendimo tikslumą buvo apskaičiuota MMVL vèlinimo trukmès dažninė priklausomybė pagal siūlomą metodiką ir palyginta su priklausomybėmis pateiktomis (Gurskas et al. 2010) darbe ir gautais naudojant programinę ịrangą Sonnet $^{\circledR}$. Analizuojamos MMVL parametrai pateikti 4.2 lenteleje, vélinimo trukmès dažninès priklausomybès -4.10 pav. 


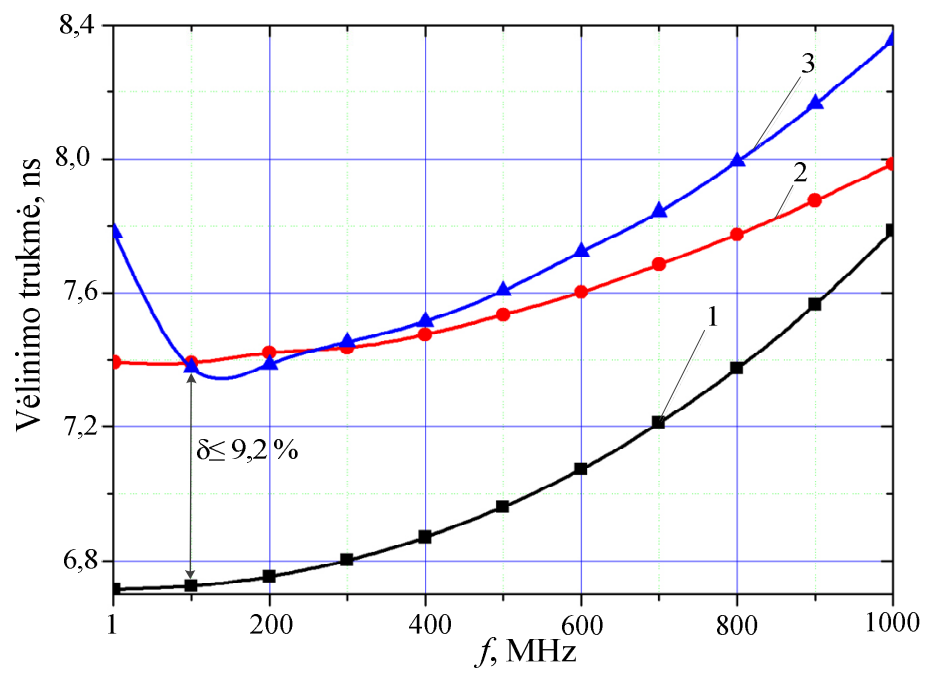

4.10 pav. Vèlinimo trukmès priklausomybès nuo dažnio, čia 1 - priklausomybè, gauta taikant siūlomą sintezès metodiką; 2 - priklausomybė pateikta (Gurskas et al. 2010) darbe; 3 - priklausomybe், gauta naudojant Sonnet ${ }^{\circledR}$ programinę įrangą

Fig. 4.10. Time delay frequency response, where 1 - response, received using proposed technique; 2 - response, received from (Gurskas et al. 2010) article; 3 - response, received using Sonnet ${ }^{\circledR}$ software

4.10 pav. pateiktuose grafikuose matyti, kad didžiausias skirtumas tarp priklausomybès, apskaičiuotos pagal siūlomą metodiką, ir pateiktos (Gurskas et al. 2010) darbe bei gautos naudojant Sonnet ${ }^{\circledR}$ programinę įrangą siekia vos $10 \%$.

4.2 lentelè. Analizuojamos MMVL konstrukciniai parametrai

Tabale 4.2. Construction parameters of the analysed MMDL

\begin{tabular}{|c|c|c|c|c|}
\hline$\varepsilon_{\mathrm{r}}$ & $h, \mathrm{~mm}$ & $W, \mathrm{~mm}$ & $S, \mathrm{~mm}$ & $\begin{array}{c}\text { Meandrinio laidininko } \\
\text { mikrojuostelių skaičius }\end{array}$ \\
\hline 9,8 & 0,50 & 0,65 & 0,35 & 55 \\
\hline
\end{tabular}

Ivertinant tai, kad (Gurskas et al. 2010) naudojamas hibridinis analizès metodas, grịstas momentų ir sklaidos matricų metodais, o Sonnet ${ }^{\circledR}$ įranga grịsta modifikuotu momentų metodu, darytina išvada, kad siūlomos metodikos neapibrěžtis yra pakankamai mažo dydžio, kad būtų naudojama inžinerinèje praktikoje.

Lygiagrečiojo MMVL dažninių charakteristikų apskaičiavimo algoritmo (4.9 pav.) efektyvumo tyrimui algoritmas buvo igyvendintas MPICH2 homogeniniame kompiuterių telkinyje (MPICH2 2011), naudojant nuo 1 iki 8 kompiuteriu (kompiuterio CPI - Pentium ${ }^{\mathrm{TM}} 4,1,7 \mathrm{GHz}$; pagrindinès atminties talpa $512 \mathrm{MB}$; operacinè sistema - Fedora 6; kompiuterių tinklas - Ethernet $1 \mathrm{~Gb} / \mathrm{s}$ ). 
Siekiant nustatyti kompiuterių telkinio našumą eksperimento metu mazgų (pavaldžiujjų kompiuterių) skaičius buvo didinamas nuo 1 iki 8. Bandymams, ieškant dispersinès lygties sprendinio, buvo taikomas „stygu“" metodas ir skaičiuojama MMVL dispersinè charakteristika, t. y. fazès lètinimo koeficiento priklausomybè nuo dažnio $10^{6}$ taškų. Gauti skaičiavimo trukmès rezultatai, esant ivvairiam kompiuterių telkinio mazgų skaičiui, pateikti 4.3 lentelejje ir 4.11 grafikuose.
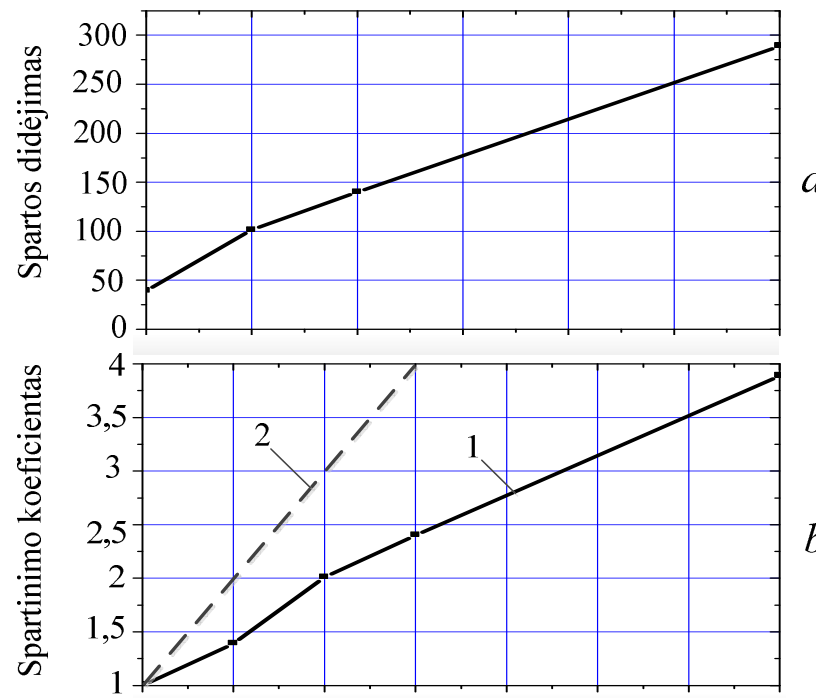

$b$

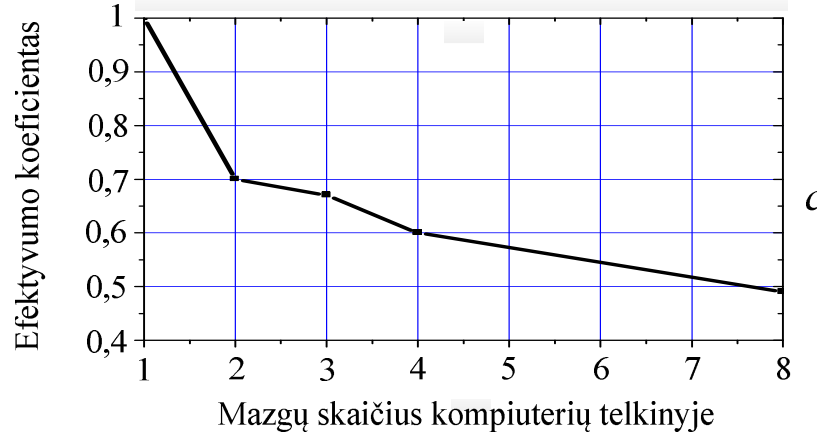

4.11 pav. Lygiagrečiojo MMVL dažninių charakteristikų apskaičiavimo algoritmo našumas: $a$ - spartos pokyčio grafikas; $b$ - spartinimo koeficiento grafikas, čia 1 - siūlomo algoritmo spartinimo koeficientas; 2 - idealus atvejis, kai spartinimo koeficientas lygus mazgų skaičiui ; $c$-algoritmo efektyvumo koeficiento grafikas

Fig. 4.11. The frequency response of the MMDL parallel algorithm effectivnes: $a$-scaliabyliti; $b$ - scalabilyti of the algorithm; $c$-effectivenes of the algorithm 
4.3 lentelė. Lygiagrečiojo MMVL dispersinès charakteristikos apskaičiavimo algoritmo efektyvumo parametrai

Table 4.3. Execution time of parallel algorithm

\begin{tabular}{|c|c|c|c|c|c|}
\hline $\begin{array}{c}\text { Algoritmo efekty- } \\
\text { vumo parametrai }\end{array}$ & \multicolumn{5}{|c|}{ Mazgu skaičius } \\
\cline { 2 - 6 } & 1 & 2 & 3 & 4 & 8 \\
\hline Vykdymo trukmè, $\mathrm{s}$ & 73,51 & 52,81 & 36,50 & 30,63 & 18,89 \\
\hline$\Delta S_{p}, \%$ & - & 39,2 & 101,4 & 140,0 & 289,1 \\
\hline$S_{p}$ & 1 & 1,39 & 2,01 & 2,40 & 3,89 \\
\hline$E_{p}$ & 1 & 0,70 & 0,67 & 0,60 & 0,49 \\
\hline
\end{tabular}

4.3 lentelèje $\Delta S_{p}=\left[\left(t_{1}-t_{p}\right) / t_{p}\right] \cdot 100 \%$ - lygiagrečiojo algoritmo spartos pokytis, algoritmo spartinimo koeficientas $S_{p}$ ir efektyvumas $E_{p}$ apskaičiuojamas atitinkamai pagal (3.3) ir (3.5) išraiškas.

4.3 lentelèje ir 4.11 pav. matyti, kad naudojant pasiūlytą algoritmą skaičiavimo trukmè mažèja, didejjant kompiuterių telkinyje skaičiui. Pastebètina, kad, padidinus mazgų skaičių dvigubai, skaičiavimų trukmė sumažèja maždaug $40 \% .4 .11$ pav. $b$ grafike matyti, kad spartinimo koeficientas didejja tiesiškai, tai nutiko dèl to, kad vykdant skaičiavimus mazgų kompiuterių telkinyje naudojama mažai. Didinant mazgų skaičių kompiuterių telkinyje grafikas turètų lètėti ir pasiekti asimptotini darbo režimą. 4.11 pav. $c$ grafikas artėja ties vieneto verte, tai rodo, kad siūlomo algoritmo efektyvumas, didinant mazgų skaičių telkinyje, mažèja t. y. didinant mazgų skaičių skaičiavimo trukmės mažèjimas lètejja. Taigi, siūlomas algoritmas gali būti vykdomas kompiuteriu telkinyje, sudarytame iš daugiau negu 8 kompiuterių, tačiau jo efektyvumas praktiškai nesikeis.

\subsection{Ketvirtojo skyriaus išvados}

1. Išnagrinèti meandrinès mikrojuostelinès vẻlinimo linijos (MMVL) dispersinès lygties sprendimo būdai. Dispersinès lygties sprendinys taikomas MMVL fazès vèlinimo trukmès ir kitoms elektrinėms charakteristikoms apskaičiuoti.

2. Aptarti ir igyvendinti keturi dispersinès lygties sprendimo metodai - skiltinio artejimo, ,dichotominis“, ,,auksinio pjūvio“ ir ,stygu“":

a) atlikus eksperimentinius skaičiavimus esant $10^{6}$ dažnio taškų, sparčiausiu algoritmu pripažintas algoritmas, grịstas „stygų“ metodu skaičiavimai pagal ji truko 73,51 s (kompiuterio CPI - Pentium ${ }^{\mathrm{TM}} 4$, 
1,7 GHz; pagrindinès atminties talpa - $512 \mathrm{MB}$; operacinè sistema Fedora 6).

b) ilgiausiai dispersinè lygtis sprendžiama pagal algoritmą, grịstą ,,auksinio pjūvio" metodu, analogiški skaičiavimai šiuo atveju truko 2,6 karto ilgiau.

3. Pasiūlytas ir igyvendintas lygiagretusis MMVL dispersinès lygties sprendimo algoritmas, grịstas ,stygų“ sprendinio paieškos metodu.

a) MMVL matematinio modelio adekvatumo tikrinimas rodo jo tinkamumą inžineriniams skaičiavimams - vẻlinimo trukmès dažninių priklausomybių, apskaičiuotu pagal siūlomą algoritmą ir gautų naudojant Sonnet ${ }^{\circledR}$ programinę irrangą bei skelbtų kitų tyrèjų, santykinis skirtumas neviršija $10 \%$.

b) siūlomas lygiagretusis algoritmas, igyvendintas aštuonių kompiuterių telkinyje, beveik 4 kartus paspartina vėlinimo trukmès dažninès priklausomybės apskaičiavimą lyginant su skaičiavimais, atliktais viename kompiuteryje. 



\section{Lygiagrečioji meandrinių mikrojuostelinių vẻlinimo linijų sintezè}

Šiame skyriuje nagrinejjama meandrinių mikrojuostelinių vèlinimo linijų (MMVL) sintezès metodika. Bendruoju atveju elektroninio ịtaiso sintezès procese iteraciškai kartojasi ịtaiso matematinio modelio analizès ir ịtaiso konstrukcinių parametrų optimizavimo etapai. Siūlomoje metodikoje naudojamas MMVL matematinis modelis, grịstas atitinkamo skerspjūvio daugialaide mikrojuosteline linija (DML), papildytas MMVL atitinkančiomis ribinėmis sąlygomis ir dispersine lygtimi, siejančia analizuojamo dažnio vertę ir fazių skirtumą tarp įtampų gretimose meandrinio laidininko mikrojuostelèse.

Svarbiausieji MMVL elektriniai parametrai - charakteringasis impedansas, vèlinimo trukmè ir praleidžiamujų dažnių juosta, todèl siūlomą MMVL sintezès metodiką sudaro iteraciškai besikartojantys siekiamų charakteringojo impedanso, vèlinimo trukmès ir praleidžiamujų dažnių juostos paieškos etapai.

Nurodyto charakteringojo impedanso DML sintezès metodika aprašyta 3 skyriuje, MMVL konstrukcija pateikta 4 skyriuje.

Skyrių sudaro du poskyriai ir išvados. Pirmame poskyryje pateikiami siūlomi lygiagrečiosios sintezès algoritmai ir aptariamas jų veikimas. Antrame po- 
skyryje pateikiami lygiagrečiujų algoritmų patikros ir tyrimų rezultatai. Pabaigoje formuluojamos skyriaus išvados.

Skyriaus medžiaga buvo pristatyta konferencijose: „Elektronika ir elektrotechnika 2011“ ir „Electronics“ 2011“.

\subsection{Meandrinių mikrojuostelinių vèlinimo linijų lygiagrečiosios sintezès algoritmai}

Svarbiausias etapas lygiagrečiosios MMVL sintezès algoritmuose - analizuojamų konstrukcinių parametrų ruožo sudarymas kompiuterių telkiniui. Gerai žinomas tolygus parametrų paskirstymas telkinio mazgams su skiltiniu artejimu ties ieškoma verte. Tačiau patrauklus, žadantis spartesnę sintezès procedūrą, yra ir atsitiktinès paieškos algoritmas, grịstas Monte Karlo metodu. Siekiant sukurti efektyvią MMVL lygiagrečiosios sintezès metodiką buvo sudaryti, igyvendinti ir išbandyti keturi sintezės algoritmai: grịsti Monte Karlo ir skiltinio artejjimo metodais.

\subsubsection{Monte Karlo metodu grịsti meandrinių mikrojuostelinių vẻlinimo linijų lygiagrečiosios sintezès algoritmai}

Projektuojant MMVL, dydžiais, ribojančiais sintezę gali būti arba linijos matmenys, arba meandrinio laidininko vėlinimo trukmès žingsnis. Taigi, sintezuojant MMVL būtina arba riboti meandrinio laidininko ilgị $l_{m}$ t. y. kontroliuoti linijos matmenis, arba fiksuoti meandrinio laidininko pakopų skaičių $N$ tokiu būdu užtikrinant nustatytą vèlinimo žingsnị. Atitinkamai galimi du MMVL sintezès algoritmai: pirmojo tipo - kuomet fiksuojamas meandrinio laidininko pakopų skaičius $N$, ir antrojo tipo - kuomet ribojamas meandrinio laidininko ilgis $l_{\mathrm{m}}$.

Pirmojo tipo, Monte Karlo metodu grịstas, MMVL lygiagrečiosios sintezès algoritmas

Sintezès algoritmas, grịstas Monte Karlo metodu, esant fiksuotam meandrinio laidininko pakopų skaičiui $N$, pateiktas 5.1 pav. Algoritmą sudaro 13 žingsnių:

1. Nustatomi pradiniai MMVL analizès parametrai (dielektrinio pagrindo storis $h$ ir santykinė dielektrinè skvarba $\varepsilon_{\mathrm{r}}$, laidininkų ir analizuojamos srities potencialai $\varphi$ ), konstrukcinių parametrų keitimo ruožai (mažiausias ir didžiausias meandrinio laidininko mikrojuostelių plotis $W_{\min }$ ir $W_{\max }$, 
mažiausias ir didžiausias tarpas tarp mikrojuostelių $S_{\min }$ ir $S_{\max }$, mažiausias ir didžiausias meandrinio laidininko aukštis $2 A_{\min }$ ir $2 A_{\max }$ ), sintezuojamos linijos nominalios elektrinių parametrų vertès (charakteringasis impedansas $Z_{0 \text { nom }}$, vèlinimo trukmé $t_{\mathrm{vnom}}$, praleidžiamųjų dažnių juosta $\Delta F_{\text {nom }}$ ) ir leistini nominalių elektrinių parametrų nuokrypiai: $\delta_{Z}$ - charakteringojo impedanso, $\delta_{t}-$ vẻlinimo trukmès, $\delta_{\Delta F}$ - praleidžiamųų dažnių juostos.

2. Pagal tolygaus pasiskirstymo dèsnị atsitiktiniu būdu generuojamos mikrojuostelių pločių vertès $W_{i}^{(P)}$, kurios parenkamos iš ruožo $\left(W_{\max }-W_{\min }\right)$. Generuojamų verčių skaičius atitinka kompiuterių telkinyje procesų skaičių $P$, kuris nurodamas aktyvuojant algoritmą.

3. Valdantysis telkinio mazgas paskirsto sugeneruotas $W_{i}^{(P)}$ vertes pavaldiesiems mazgams. Visi telkinio mazgai atlieka charakteringojo impedanso $Z_{0 i}^{(P)}$ apskaičiavimą. Apskaičiavus $Z_{0 i}^{(P)}$, atliekamas šių verčių gražinimas valdančiajam mazgui, kur jos grupuojamos i bendrą masyvą $\left[Z_{0 i}^{(P)}\right]$.

4. Masyve $\left[Z_{0 i}^{(P)}\right]$ atliekama charakteringojo impedanso, artimiausio $Z_{0 \text { nom }}$ paieška. Jeigu tenkinama sąlyga $\min \left[\delta\left(Z_{0 i}\right)\right] \leq \delta_{Z}$, čia $\delta\left(Z_{0 i}\right)=\left(Z_{0 i}^{(P)}-Z_{0 \text { nom }}\right) / Z_{0 \text { nom }} i$-osios apskaičiuotos ir nominalios charakteringojo impedanso verčių santykinis skirtumas - pereinama ties 6 žingsniu. Jeigu sąlyga $\min \left[\delta\left(Z_{0 i}\right)\right] \leq \delta_{Z}$ netenkinama - pereinama ties 5 žingsniu.

5. Kuomet surastoji artimiausia charakteringojo impedanso vertė netenkina leistino nuokrypio (t. y. $\min \left[\delta\left(Z_{0 i}\right)\right] \leq \delta_{Z}$ ), pagal normaliojo pasiskirstymo dèsni generuojamos naujos $W_{i}^{(P)}$ vertès:

$$
f\left(W_{i}^{(P)}\right)=\frac{1}{\sqrt{2 \pi \sigma_{\mathrm{W}}^{2}}} \cdot \exp \left(-\frac{\left(W_{i}^{(P)}-W_{\mu}\right)^{2}}{2 \sigma_{\mathrm{W}}^{2}}\right),
$$

čia $W_{i}^{(P)}$ - nauja generuojama vertè; $W_{\mu}$ - mikrojuostelès, atitinkančios artimiausią apskaičiuotą charakteringojo impedanso vertę nominaliai ver- 
tei, plotis; $\sigma_{\mathrm{W}}-$ nuokrypis nuo $W_{\mu}$ vertès. Pereinama ties 3 žingsniu, taip kartojant skaičiavimus tol, kol nebus rasta $Z_{0 i}^{(P)}$ verte, tenkinanti $\min \left[\delta\left(Z_{0 i}\right)\right] \leq \delta_{Z}$ sąlygą.

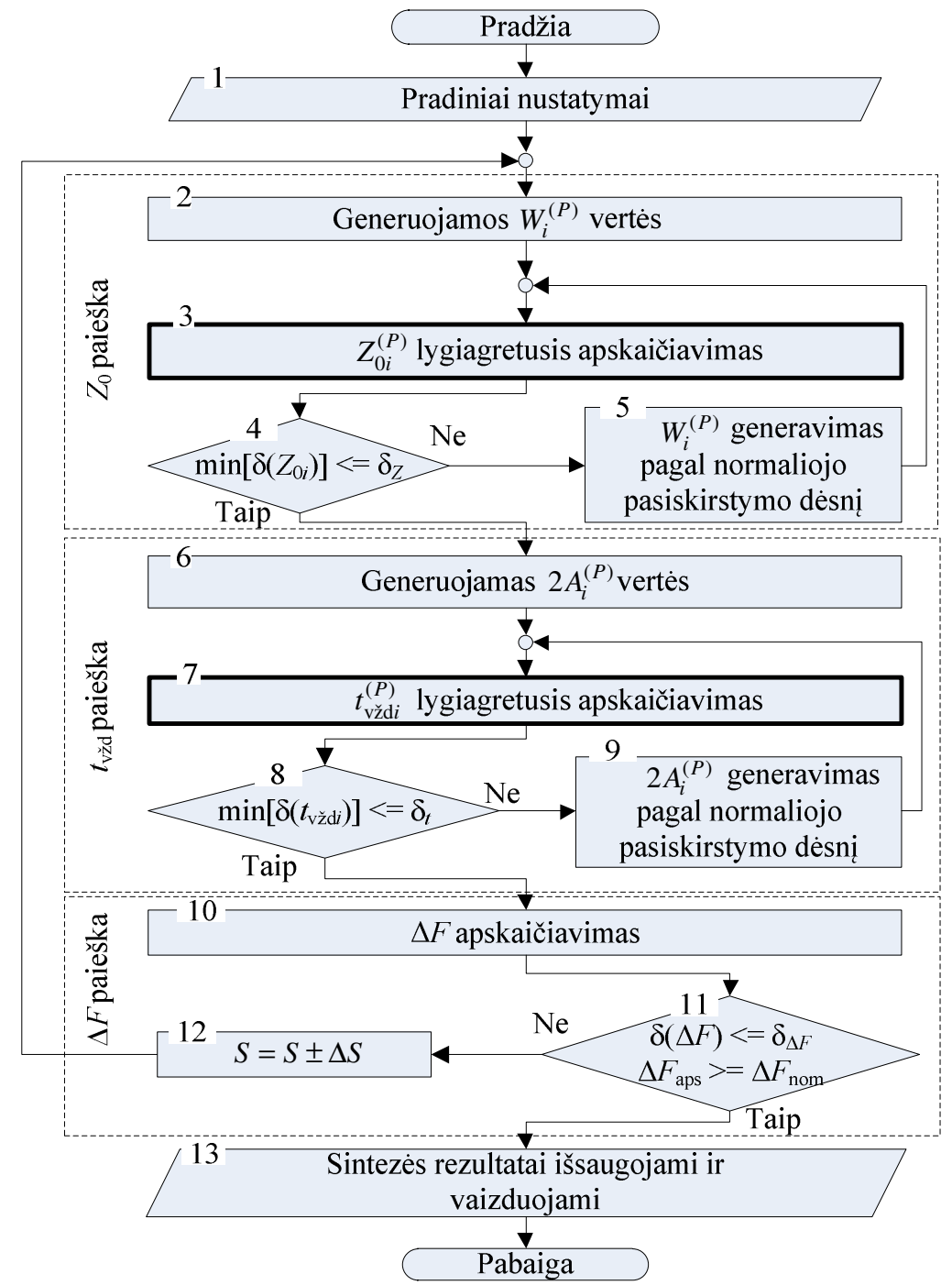

5.1 pav. Lygiagretusis meandrinių mikrojuostelinių vèlinimo linijų sintezès algoritmas, grịstas Monte Karlo metodu, esant fiksuotam laidininkų pakopų skaičiui

Fig 5.1. Parallel algorithm of synthesis of the microstrip meander delay line, based on Monte Carlo method with fixed conductors step number 
6. Pagal tolygaus pasiskirstymo dèsnị atsitiktiniu būdu generuojamos meandrinio laidininko aukščio vertės $2 A_{i}^{(P)}$, kurios parenkamos iš ruožo $\left(2 A_{\max }-2 A_{\min }\right)$. Generuojamų verčių skaičius atitinka nustatytą procesų skaičių $P$.

7. Valdantysis telkinio mazgas paskirsto sugeneruotas $2 A_{i}^{(P)}$ vertes pavaldiesiems mazgams. Visi telkinio mazgai atlieka vėlinimo trukmės esant žemiesiems dažniams apskaičiavimą. Apskaičiuotos $t_{\mathrm{vZD} i}^{(P)}$ vertès gražinamos valdančiajam mazgui, kur jos surenkamos ị bendrą masyvą $\left[t_{\mathrm{vZD} i}^{(P)}\right]$.

8. Masyve $\left[t_{\mathrm{vZD} i}^{(P)}\right]$, atliekama vėlinimo trukmès, artimiausios $t_{\mathrm{vnom}}$ paieška. Jeigu tenkinama sąlyga $\min \left[\delta\left(t_{\mathrm{vzd} i}\right)\right] \leq \delta_{t}$, čia $\min \left[\delta\left(t_{\mathrm{vzd} i}\right)\right]$ - mažiausios apskaičiuotos ir nominalios vèlinimo trukmès, esant žemiesiems dažniams, santykinis skirtumas - pereinama ties 10 žingsniu. Jeigu sąlyga $\min \left[\delta\left(t_{\mathrm{vZD} i}\right)\right] \leq \delta_{t}$ netenkinama - pereinama ties 9 žingsniu.

9. Kuomet surastoji artimiausia vèlinimo trukmès vertė netenkina leistino nuokrypio (t. y. $\min \left[\delta\left(\begin{array}{ll}t_{\mathrm{v}} \mathrm{d} i\end{array}\right)\right] \leq \delta_{t}$ ), naujos $2 A_{i}^{(P)}$ vertès generuojamos pagal normaliojo pasiskirstymo dèsnị:

$$
f\left(2 A_{i}^{(P)}\right)=\frac{1}{\sqrt{2 \pi \sigma_{\mathrm{A}}^{2}}} \cdot \exp \left(-\frac{\left(2 A_{i}^{(P)}-2 A_{\mu}\right)^{2}}{2 \sigma_{A}^{2}}\right),
$$

čia $2 A_{i}^{(P)}$ - nauja generuojama vertė; $2 A_{\mu}$ - meandrinio laidininko, atitinkančios artimiausią apskaičiuotą vẻlinimo trukmę nominaliai trukmei; plotis, $\sigma_{2 A}$ - nuokrypis nuo $2 A_{\mu}$ vertès. Pereinama ties 7 žingsniu, taip kartojant skaičiavimus, tol kol nebus rasta $t_{\mathrm{vZD} i}^{(P)}$ vertè tenkinanti $\min \left[\delta\left(t_{\mathrm{vZD} i}\right)\right] \leq \delta_{t}$ sąlygą.

10. Paskutinysis MMVL sintezès metu apskaičiuojamas dydis yra praleidžiamųų dažnių juosta $\Delta F$. Jai apskaičiuoti taikoma sintezuojamos vèlinimo linijos dažninè fazès charakteristika DFCh, kuri gaunama sprendžiant dispersinę lygtị (žr. 4 sk.). 
11. Apskaičiuojamos MMVL idealios ir realios DFCh-ų skirtumas. Kuomet šis skirtumas tampa lygus 0,35 radianų ar daugiau priimama, kad esamas dažnis atitinka praleidžiamųų dažnių juostos plotị. Jeigu praleidžiamụjų dažnių juosta tenkiną sąlygą $\delta(\Delta F) \leq \delta_{\Delta F}$, čia $\delta(\Delta F)$ - apskaičiuoto ir nominalaus praleidžiamųjų dažnių juostos pločių santykinis skirtumas, arba $\Delta F_{\text {aps }} \geq \Delta F_{\text {nom }}$, tuomet pereinama ties 13 žingsniu. Jeigu sąlyga nèra tenkinama - pereinama ties 12 žingsniu.

12. Jeigu apskaičiuota praleidžiamujjų dažnių juosta nèra pakankamai plati t. y. ji netenkina sąlygos $\delta(\Delta F) \leq \delta_{\Delta F}$ arba $\Delta F_{\text {aps }}<\Delta F_{\text {nom }}$ - atitinkamai keičiamas tarpas tarp mikrojuostelių $S$ ir gričtama ties 2 žingsniu.

13. Surasti ir apskaičiuoti susintezuotos MMVL konstrukciniai ir elektriniai parametrai yra išsaugomi ir vaizduojami.

\section{Antrojo tipo, Monte Karlo metodu grịstas, MMVL lygiagrečiosios sintezès algoritmas}

Sintezès algoritmas, grịstas Monte Karlo metodu, esant fiksuotam meandrinio laidininko ilgiui $l_{\mathrm{m}}$, pateiktas 5.2 pav. Algoritmą sudaro 14 žingsnių:

1. Nustatomi pradiniai MMVL analizès parametrai (dielektrinio pagrindo storis $h$ ir santykinė dielektrinè skvarba $\varepsilon_{\mathrm{r}}$, laidininkų ir analizuojamos srities potencialai $\varphi$ ), konstrukcinių parametrų keitimo ruožai (mažiausias ir didžiausias meandrinio laidininko mikrojuostelių plotis $W_{\min }$ ir $W_{\max }$, mažiausias ir didžiausias tarpas tarp mikrojuostelių $S_{\min }$ ir $S_{\max }$, mažiausias ir didžiausias meandrinio laidininko aukštis $2 A_{\min }$ ir $2 A_{\max }$ ), sintezuojamos linijos nominalios elektrinių parametrų vertès (charakteringasis impedansas $Z_{0 \text { nom }}$, vèlinimo trukmé $t_{\mathrm{vnom}}$, praleidžiamujjų dažnių juosta $\Delta F_{\text {nom }}$ ) ir leistini nominalių elektrinių parametrų nuokrypiai: $\delta_{Z}-$ charakteringojo impedanso, $\delta_{t}-$ vèlinimo trukmès, $\delta_{\Delta F}$ - praleidžiamųjų dažnių ruožo.

2. Pagal tolygaus pasiskirstymo dèsnị atsitiktiniu būdu generuojamos mikrojuostelių pločių vertès $W_{i}^{(P)}$, kurios parenkamos iš ruožo $\left(W_{\max }-W_{\min }\right)$. Generuojamų verčių skaičius atitinka kompiuterių telkinyje procesų skaičių $P$, kuris nurodamas aktyvuojant algoritmą.

3. Valdantysis telkinio mazgas paskirsto sugeneruotas $W_{i}^{(P)}$ vertes pavaldiesiems mazgams. Visi telkinio mazgai atlieka charakteringojo impedanso $Z_{0 i}^{(P)}$ apskaičiavimą. Apskaičiavus $Z_{0 i}^{(P)}$, atliekamas šių verčių graži- 
nimas valdančiajam mazgui, kur jos grupuojamos ị bendrą masyvą $\left[Z_{0 i}^{(P)}\right]$.

4. Masyve $\left[Z_{0 i}^{(P)}\right]$ atliekama charakteringojo impedanso, artimiausio $Z_{0 \text { nom }}$ paieška. Jeigu tenkinama sąlyga $\min \left[\delta\left(Z_{0 i}\right)\right] \leq \delta_{Z}$, čia $\delta\left(Z_{0 i}\right)=\left(Z_{0 i}^{(P)}-Z_{0 \text { nom }}\right) / Z_{0 \text { nom }} i$-osios apskaičiuotos ir nominalios charakteringojo impedanso verčių santykinis skirtumas - pereinama ties 6 žingsniu. Jeigu sąlyga $\min \left[\delta\left(Z_{0 i}\right)\right] \leq \delta_{Z}$ netenkinama - pereinama ties 5 žingsniu.

5. Kuomet surastoji artimiausia charakteringojo impedanso vertė netenkina leistino nuokrypio (t. y. $\min \left[\delta\left(Z_{0 i}\right)\right] \leq \delta_{Z}$ ), pagal normaliojo pasiskirstymo dèsni generuojamos naujos $W_{i}^{(P)}$ vertès (5.1). Pereinama ties 3 žingsniu, taip kartojant skaičiavimus tol, kol nebus rasta $Z_{0 i}^{P}$ verté, tenkinanti $\min \left[\delta\left(Z_{0 i}\right)\right] \leq \delta_{Z}$ sąlygą.

6. Apskaičiuojamas MMVL pakopų skaičius $N$

$$
N=\frac{l_{\mathrm{m}}+S}{W+S} .
$$

7. Pagal tolygaus pasiskirstymo dèsnị atsitiktiniu būdu generuojamos meandrinio laidininko aukščio vertès $2 A_{i}^{(P)}$, kurios parenkamos iš ruožo $\left(2 A_{\max }-2 A_{\min }\right)$. Generuojamų verčių skaičius atitinka pasirinktų procesų skaičių $P$.

8. Valdantysis telkinio mazgas paskirsto sugeneruotas $2 A_{i}^{(P)}$ vertes pavaldiesiems mazgams. Visi telkinio mazgai atlieka vẻlinimo trukmès esant žemiesiems dažniams apskaičiavimą. Apskaičiuotos $t_{\mathrm{vZD} i}^{(P)}$ vertės gražinamos valdančiajam mazgui, kur jos surenkamos ị bendrą masyvą $\left[t_{\mathrm{vZD} i}^{(P)}\right]$.

9. Masyve $\left[t_{\mathrm{vZD} i}^{(P)}\right]$, atliekama vėlinimo trukmės, artimiausios $t_{\mathrm{vnom}}$ paieška. Jeigu tenkinama sąlyga $\min \left[\delta\left(t_{\mathrm{vZD} i}\right)\right] \leq \delta_{t}$, čia $\min \left[\delta\left(t_{\mathrm{vZD} i}\right)\right]-$ mažiausios apskaičiuotos ir nominalios vėlinimo trukmès, esant žemiesiems 
dažniams, santykinis skirtumas - pereinama ties 11 žingsniu. Jeigu sąlyga $\min \left[\delta\left(t_{\mathrm{vZD} i}\right)\right] \leq \delta_{t}$ netenkinama - pereinama ties 10 žingsniu.

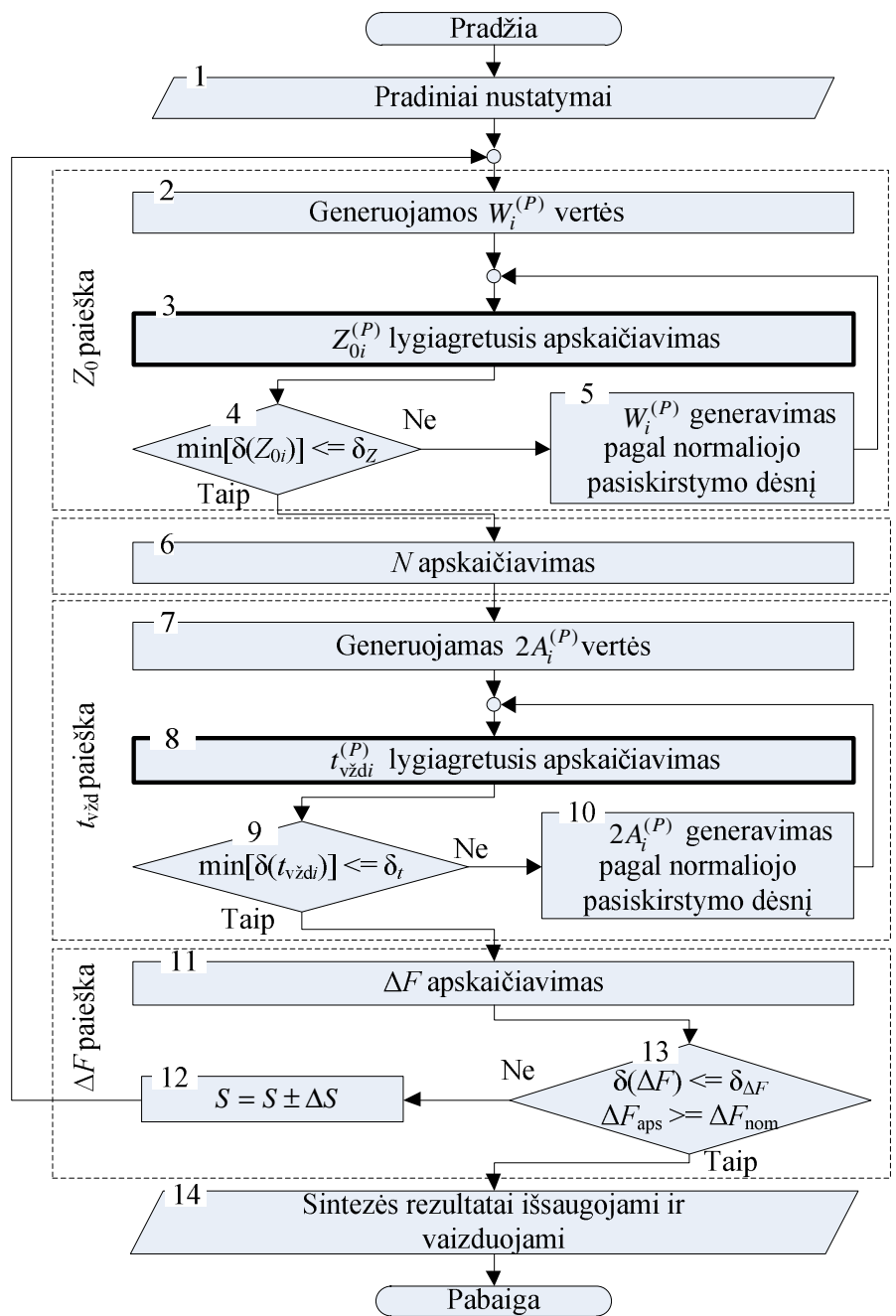

5.2 pav. Lygiagretusis meandrinių mikrojuostelinių vèlinimo linijų sintezės algoritmas, gristas Monte Karlo metodu esant, fiksuotam meandrinio laidininko ilgiui

Fig 5.2. Parallel algorithm of synthesis of the microstrip meander delay line, based on Monte Carlo method with fixed of meander conductor lengh 
10.Kuomet surastoji artimiausia vèlinimo trukmès vertė netenkina leistino nuokrypio (t. y. $\left.\min \left[\delta\left(t_{\mathrm{vzd} i}\right)\right] \leq \delta_{t}\right)$, pagal normaliojo pasiskirstymo désni generuojamos naujos $2 A_{i}^{(P)}$ vertès (5.2). Pereinama ties 7 žingsniu, taip kartojant skaičiavimus, tol kol nebus rasta $t_{\mathrm{vzd} i}^{(P)}$ verté tenkinanti $\min \left[\delta\left(t_{\mathrm{vzd} i}\right)\right] \leq \delta_{t}$ sąlygą.

11. Paskutinysis MMVL sintezès metu apskaičiuojamas dydis yra praleidžiamųų dažnių juosta $\Delta F$. Jai apskaičiuoti taikoma sintezuojamos vèlinimo linijos dažninè fazès charakteristika - DFCh, kuri gaunama sprendžiant dispersinę lygti (žr. 4 sk.).

12. Apskaičiuojamos MMVL idealios ir realios DFCh-ų skirtumas. Kuomet šis skirtumas tampa lygus 0,35 radianų ar daugiau priimama, kad esamas dažnis atitinka praleidžiamųjų dažnių juostos plotị. Jeigu praleidžiamujjų dažnių juosta tenkiną sąlygą $\delta(\Delta F) \leq \delta_{\Delta F}$, čia $\delta(\Delta F)$ - apskaičiuoto ir nominalaus praleidžiamųjų dažnių juostos pločių santykinis skirtumas, arba $\Delta F_{\text {aps }} \geq \Delta F_{\text {nom }}$, tuomet pereinama ties 14 žingsniu. Jeigu sąlyga nèra tenkinama - pereinama ties 13 žingsniu.

13. Jeigu apskaičiuota praleidžiamujjų dažnių juosta nėra pakankamai plati t. y. ji netenkina sąlygos $\delta(\Delta F) \leq \delta_{\Delta F}$ arba $\Delta F_{\text {aps }}<\Delta F_{\text {nom }}$ - atitinkamai keičiamas tarpas tarp mikrojuostelių $S$ ir grịžtama ties 2 žingsniu.

14. Surasti ir apskaičiuoti susintezuotos MMVL konstrukciniai ir elektriniai parametrai yra išsaugomi ir vaizduojami.

\subsubsection{Skiltinio artėjimo metodu grịsti meandrinių mikrojuoste- linių vẻlinimo linijų lygiagrečiosios sintezès algoritmai}

MMVL lygiagrečiosios sintezès algoritmai, grịsti skiltinio artejimo metodu, skiriasi nuo algoritmų, grịstu Monte Karlo metodu, MMVL konstrukcinių parametrų paieškos būdais.

Skiltinio artèjimo paieškos principas pateiktas 5.3 pav. Paveiksle matyti, kad pradinis konstrukcinio parametro verčių ruožas $\left(X_{\max }-X_{\min }\right)$ tolygiai dalinamas i $P$ verčių intervalus tarp $p$ telkinio mazgų (5.3 pav., a). Tuomet telkinio mazguose vyksta sintezuojamos MMVL lygiagrečioji analizė - apskaičiuojamos tam tikro elektrinio parametro vertès ir tarp jų ieškoma artimiausia nominaliai. 


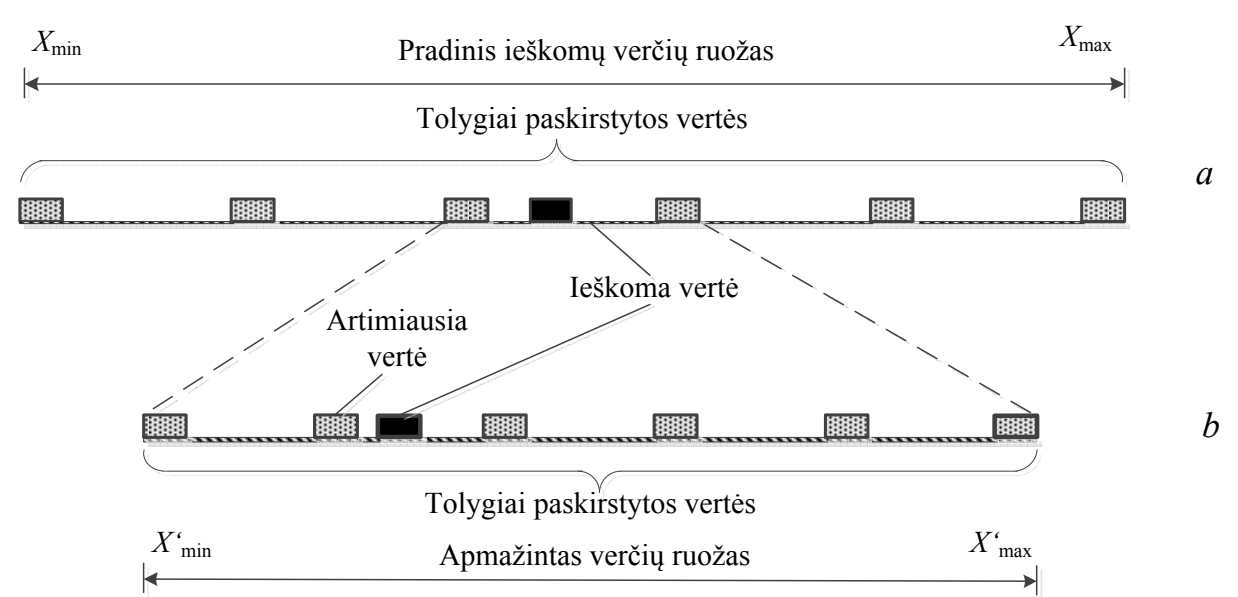

5.3 pav. Verčių ruožo dalinimas kompiuterių telkinio mazgams $(a)$ ir verčių ruožo apmažinimas nustačius artimiausią vertę $(b)$

Fig 5.3. Values distribution among cluster nodes $(a)$ and norrowing of values range by finded nearest value to the searched $(b)$

Pagal surastą artimiausią elektrinio parametro vertę sudaromas naujas, apmažintas konstrukcinio parametro verčių ruožas $\left(X_{\max }^{\prime}-X_{\min }^{\prime}\right)$, ir vèl tolygiai dalinamas tarp telkinio mazgų (5.3 pav., b). Ši procedūra kartojasi tol, kol surasta artimiausia elektrinio parametro vertè netenkins sąlygos $\min \left[\delta\left(e_{i}\right)\right] \leq \delta_{e}$, čia $\delta\left(e_{i}\right)=\left(e_{i}-e_{\text {nom }}\right) / e_{\text {nom }}$ - elektrinio parametro $e$ apskaičiuotos ir nominalios verčių santykinis skirtumas; $\delta_{e}$ - leistinas elektrinio parametro $e$ nuokrypis.

\section{Pirmojo tipo, skiltinio artẻjimo metodu grịstas, MMVL lygiagrečiosios sin- tezès algoritmas}

MMVL sintezės algoritmų, grịstų Monte Karlo ir skiltinio artejimo metodais, procedūros didesne dalimi panašios todèl čia aprašysime tik skirtingus algoritmų žingsnius. Pirmojo tipo algoritmas grịstas skiltinio artejjimo metodu, ir esant fiksuotam meandrinio laidininkų pakopų skaičiui $N$ pateiktas 5.4 pav. 


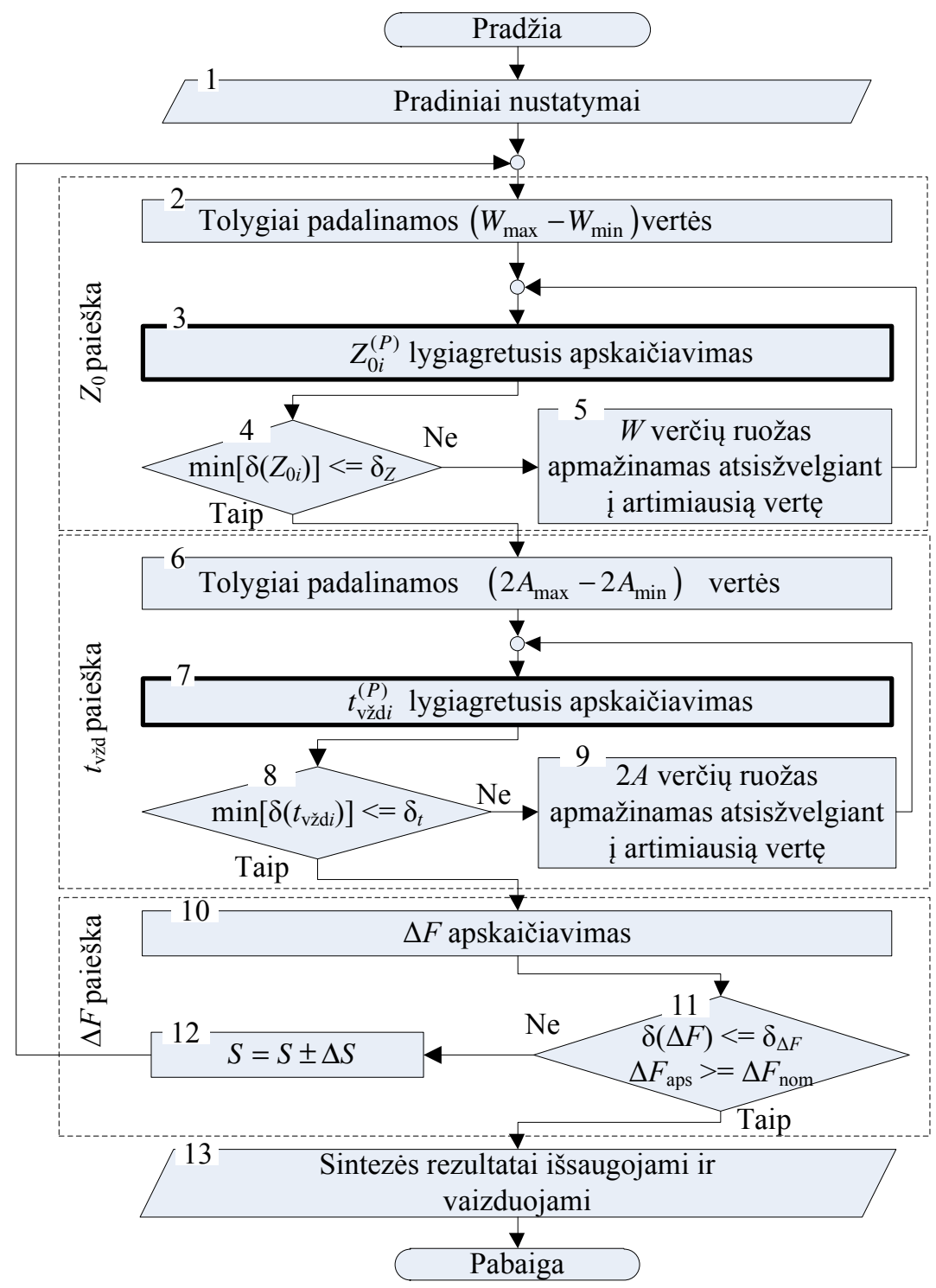

5.4 pav. Lygiagretusis meandrinių mikrojuostelinių vėlinimo linijų sintezès algoritmas, grịstas skiltinio artèjimo metodu, esant fiksuotam meandrinio laidininko pakopų skaičiui Fig 5.4. Algorithm of parallel synthesis of the microstrip meander delay line, based on successive aproximation method with fixed number of steps of meander conductors 
Algoritmą sudaro 13 žingsnių, jis skiriasi nuo algoritmo, grịsto Monte Karlo metodu atitinkamai 2, 5, 6 ir 9 žingsniais:

2. Tolygiai skirstomas $W_{\max }-W_{\min }$ mikrojuostelių pločio pradinis ruožas ị tiek verčių $W_{i}^{(P)}$, kiek sukurta procesų $P$ kompiuterių telkinyje.

5. Vienu žingsniu apmažinamas pradinis $W_{\max }-W_{\min }$ mikrojuostelių pločio ruožas ị $W_{\max }^{\prime}-W_{\min }^{\prime}$ pagal surastą artimiausią $W_{i}^{(P)}$ vertę, čia $W_{\max }^{\prime}=W_{i}^{(P)}$, kai surasta artimiausia charakteringojo impedanso verte yra mažesnè už nominalią $Z_{0 i}^{(P)}<Z_{0 \text { nom }}$ ir $W_{\min }^{\prime}=W_{i}^{(P)}$, kai artimiausia charakteringojo impedanso vertė yra didesnè už nominalią $Z_{0 i}^{(P)}>Z_{0 \text { nom }}$.

6. Tolygiai skirstomas $2 A_{\max }-2 A_{\min }$ meandrinio laidininko aukščio pradinis ruožas ị tiek verčių $2 A_{i}^{(P)}$, kiek yra procesų $P$ kompiuterių telkinyje.

9. Vienu žingsniu apmažinamas pradinis $2 A_{\max }-2 A_{\min }$ ruožas ị $2 A_{\max }^{\prime}-2 A_{\min }^{\prime}$ pagal surastą artimiausią $2 A_{i}^{(P)}$ vertę, čia $2 A_{\max }^{\prime}=2 A_{i}^{(P)}$, kai surasta artimiausia vèlinimo trukmès esant žemiesiems dažniams vertė yra mažesnè už nominalią $t_{\mathrm{vzd} i}^{(P)}<t_{\mathrm{vnom}}$ ir $2 A_{\min }^{\prime}=2 A_{i}^{(P)}$, kai artimiausia vèlinimo trukmès vertè yra didesnè už nominalią $t_{\mathrm{vzd} i}^{(P)}>t_{\mathrm{v} \text { nom }}$.

\section{Antrojo tipo, skiltinio artẻjimo metodu grịstas, MMVL lygiagrečiosios sintezès algoritmas}

Antrojo tipo algoritmas, grịstas skiltinio artejjimo metodu ir esant fiksuotam meandrinio laidininko ilgiui $l_{\mathrm{m}}$, pateiktas 5.5 pav. Algoritmą sudaro 14 žingsnių, jis skiriasi nuo algoritmo, grịsto Monte Karlo metodu atitinkamai 2, 5, 6, 7 ir 10 žingsniais:

2. Tolygiai skirstomas $W_{\max }-W_{\min }$ mikrojuostelių pločio pradinis ruožas ị tiek verčių $W_{i}^{(P)}$, kiek sukurta procesų $P$ kompiuterių telkinyje. 


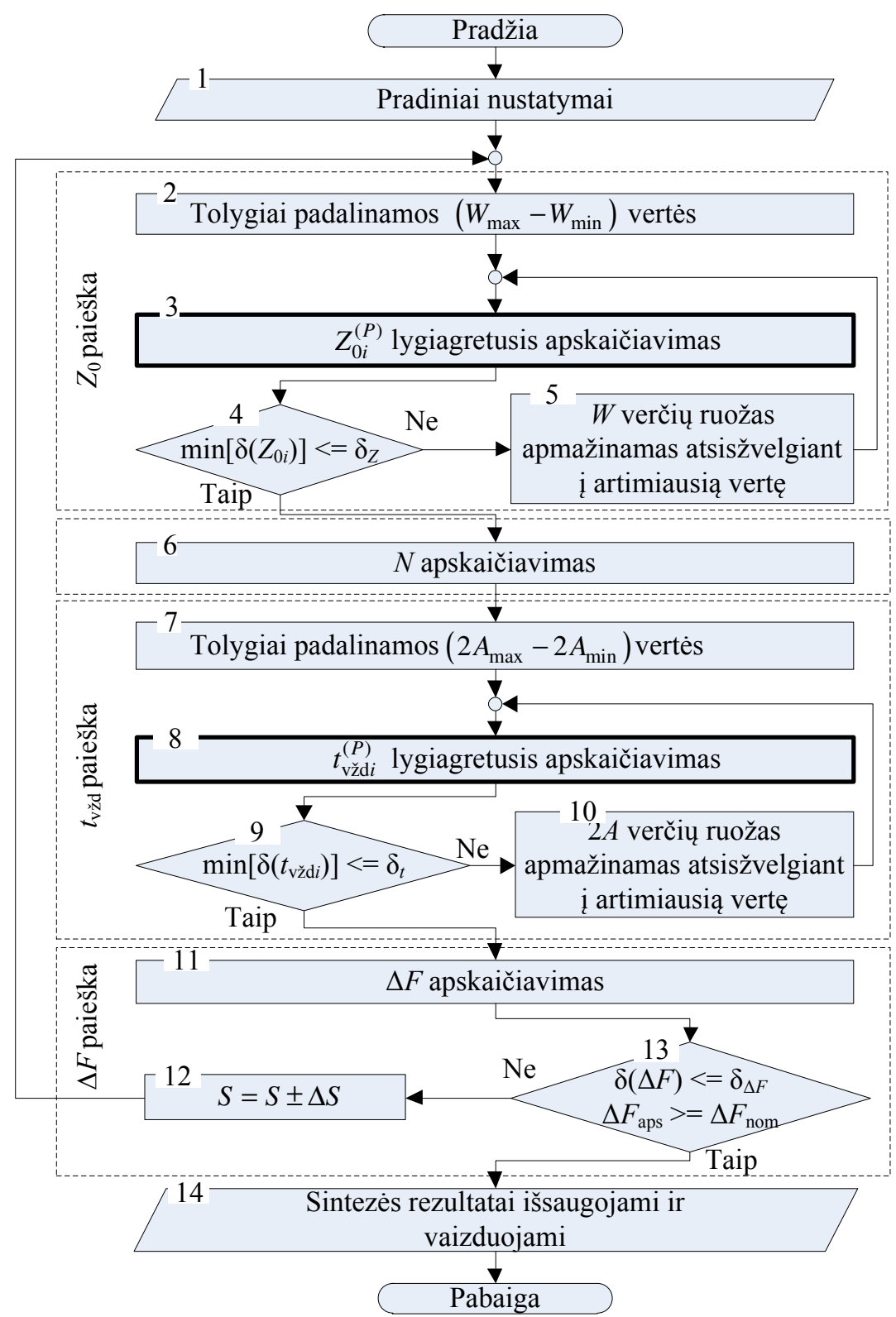

5.5 pav. Lygiagretusis meandrinių mikrojuostelinių vèlinimo linijų sintezės algoritmas, grịstas skiltinio artejjimo metodu, esant fiksuotam linijos meandrinio laidininko ilgiui Fig 5.5. Algorithm of parallel synthesis of the microstrip meander delay line, based on successive aproximation method with fixed MMDL lengh 
5. Vienu žingsniu apmažinamas pradinis $W_{\max }-W_{\min }$ mikrojuostelių pločio ruožas ị $W_{\max }^{\prime}-W_{\min }^{\prime}$ pagal surastą artimiausią $W_{i}^{(P)}$ vertę, čia $W_{\max }^{\prime}=W_{i}^{(P)}$, kai surasta artimiausia charakteringojo impedanso verte yra mažesnè už nominalią $Z_{0 i}^{(P)}<Z_{0 \text { nom }}$ ir $W_{\min }^{\prime}=W_{i}^{(P)}$, kai artimiausia charakteringojo impedanso vertè yra didesnè už nominalią $Z_{0 i}^{(P)}>Z_{0 \text { nom }}$.

6. Apskaičiuojamas MMVL pakopų skaičius $N$ pagal (5.3).

7. Tolygiai skirstomas $2 A_{\max }-2 A_{\min }$ meandrinio laidininko aukščio pradinis ruožas ị tiek verčių $2 A_{i}^{(P)}$, kiek yra procesų $P$ kompiuterių telkinyje.

10. Žingsniu apmažinamas pradinis $2 A_{\max }-2 A_{\min }$ ruožas i $2 A_{\max }^{\prime}-2 A_{\min }^{\prime}$ pagal surastą artimiausią $2 A_{i}^{(P)}$ vertę, čia $2 A_{\max }^{\prime}=2 A_{i}^{(P)}$, kai surasta artimiausia vėlinimo trukmės esant žemiesiems dažniams vertė yra mažesnè už nominalią $t_{\mathrm{vzd} i}^{(P)}<t_{\mathrm{v} \text { nom }}$ ir $2 A_{\text {min }}^{\prime}=2 A_{i}^{(P)}$, kai artimiausia vèlinimo trukmès vertè yra didesnè už nominalią $t_{\mathrm{vzd} i}^{(P)}>t_{\mathrm{v} \text { nom }}$.

\subsection{Algoritmų patikra}

MMVL lygiagrečiosios sintezès metodikos tyrimas buvo atliktas trimis etapais. Pirmuоju еtapu patikrintas MMVL matematinio modelio adekvatumas, antruoju etapu atliktas MMVL sintezès funkcionalumo tyrimas, trečiиoju etapu ištirtas lygiagrečiųjų algoritmų našumas.

\subsubsection{Matematinio modelio adekvatumo patikra}

MMVL matematinio modelio adekvatumas buvo patikrintas palyginant sintezuotos vélinimo linijos elektrinius parametrus su (Gurskas et al. 2010) straipsnyje pateiktais parametrais ir parametrais, gautais naudojant mikrobanginių ịtaisų analizès komercinę programinę ịrangą Sonnet ${ }^{\circledR}$. Parametrų palyginimo rezultatai pateikti 5.1 lenteleje. 5.6 pav. parodytas Sonnet ${ }^{\circledR}$ terpeje sudarytas MMVL modelis ir 5.7 pav. pateiktos fazès vèlinimo trukmès priklausomybès nuo dažnio, gautos naudojant siūlomą modelį, komercinę programinę ịrangą Sonnet ${ }^{\circledR}$ ir publikuotas (Gurskas et al. 2010) darbe. 
5.1 lenteleje ir 5.7 pav. matyti, kad santykinis skirtumas daugumos elektrinių parametrų bei charakteristikų MMVL, sintezuotos pagal siūlomą metodiką ir parametrų bei charakteristikų, gautų naudojant programinę ịrangą Sonnet ${ }^{\circledR}$ ir publikuotų (Gurskas et al. 2010) darbe, neviršija $10 \%$, šiek tiek didesnis skirtumas gautas apskaičiuojant praleidžiamųų dažnių juostos plotį.

5.1 lentelė. Sintezuotos MMVL elektrinių parametrų palyginimas su (A. Gurskas et al 2010) straipsnyje pateiktais parametrais ir parametrais gautais naudojant komercinę programinę i̇rangą Sonnet ${ }^{\circledR}$. Konstrukciniai MMVL parametrai yra šie: $\varepsilon_{\mathrm{r}}=9,85$; $h=0,5 \mathrm{~mm} ; W=0,75 \mathrm{~mm} ; S=0,30 \mathrm{~mm} ; 2 A=20 \mathrm{~mm}$

Tabale 5.1. Compare of the electrical parameters of the synthesed MDML with parameters presented in the (A. Gurskas et al 2010) article, and parameters calculated using Sonnet $^{\circledR}$ software. Construction parameters of the MDML are these: $\varepsilon_{\mathrm{r}}=9.85$; $h=0.5 \mathrm{~mm} ; W=0.75 \mathrm{~mm} ; S=0.30 \mathrm{~mm} ; 2 A=20 \mathrm{~mm}$

\begin{tabular}{|c|c|c|c|}
\hline \multirow{2}{*}{$\begin{array}{c}\text { Parametrų apskaičiavimo } \\
\text { priemoné }\end{array}$} & \multicolumn{3}{|c|}{ Elektriniai parametrai } \\
\cline { 2 - 4 } & $t_{\mathrm{v} \text { ZD }}, \mathrm{ns}$ & $Z_{0}, \Omega$ & $\Delta F, \mathrm{MHz}$ \\
\hline Pagal siūlomą metodiką sintezuota MMVL & 6,72 & 61,50 & 364,00 \\
\hline $\begin{array}{c}\text { (A. Gurskas et al 2010) straipsnyje analizuo- } \\
\text { jama MMVL }\end{array}$ & 7,39 & 61,50 & 510,00 \\
\hline $\begin{array}{c}\text { Sonnet } \\
\text { programine iranga analizuojama } \\
\text { MMVL }\end{array}$ & 7,38 & - & 475,00 \\
\hline
\end{tabular}

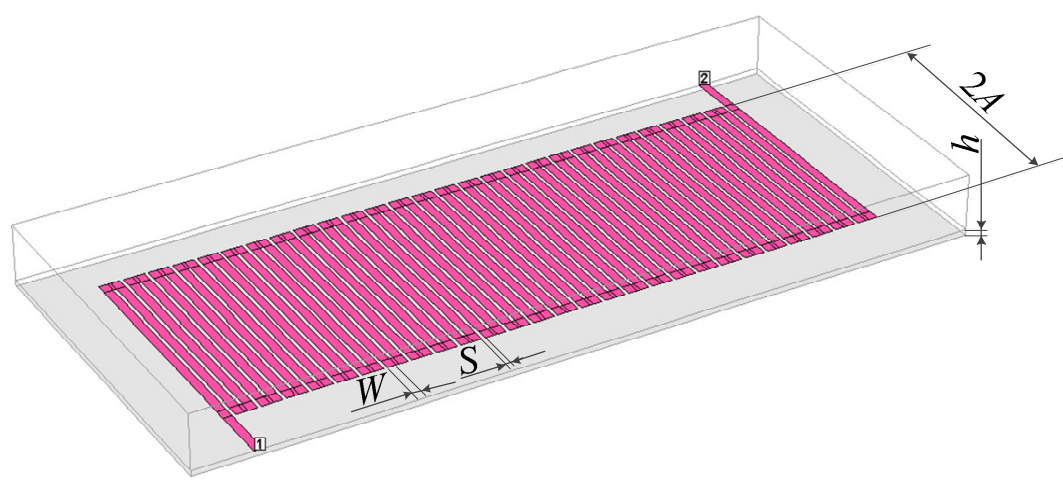

5.6 pav. MMVL modelis sudarytas programinès ịrangos Sonnet ${ }^{\circledR}$ terpèje, čia $\varepsilon_{\mathrm{r}}=9,85 ; h=0,5 \quad \mathrm{~mm} ; W=0,75 \mathrm{~mm} ; S=0,30 \mathrm{~mm} ; 2 A=20 \mathrm{~mm}$

Fig 5.6. Model of MDML model created using Sonnet ${ }^{\circledR}$ software, where $\varepsilon_{\mathrm{r}}=9.85$; $h=0.5 \mathrm{~mm} ; W=0.75 \mathrm{~mm} S=0.30 \mathrm{~mm} ; 2 A=20 \mathrm{~mm}$ 


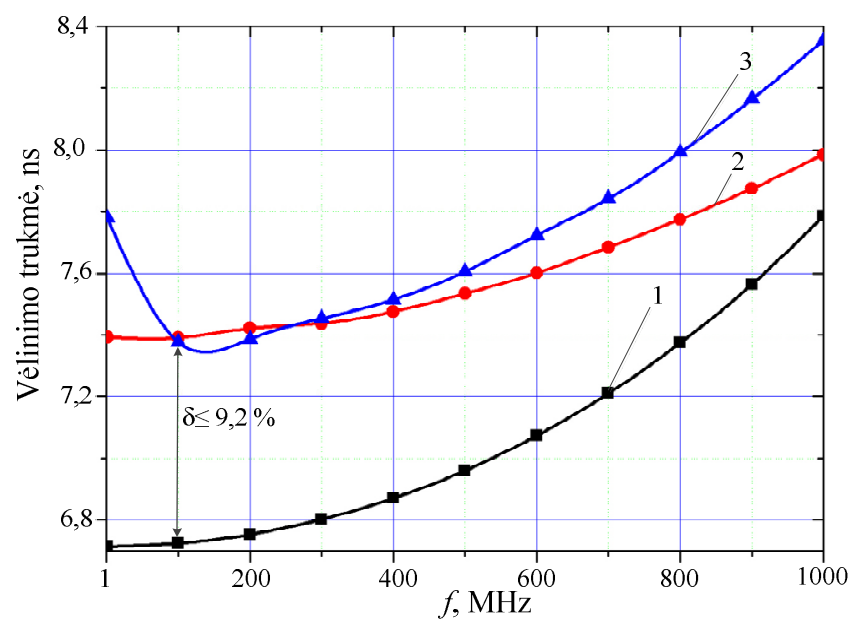

5.7 pav. Vèlinimo trukmès priklausomybès nuo dažnio, čia 1 - priklausomybè, gauta taikant siūlomą sintezès metodiką; 2 - priklausomybė gauta (Gurskas et al. 2010) darbe;

3 - priklausomybè, gauta naudojant Sonnet ${ }^{\circledR}$ programinę ịrangą

Fig 5.7. Time delay frequency response, where 1 - response, received using proposed technique; 2 - response, received from (Gurskas et al. 2010) article; 3 - response, received using Sonnet ${ }^{\circledR}$ software

Šie skirtumai gali būti paaiškinti tuo, kad Sonnet ${ }^{\circledR}$ ir (Gurskas et al. 2010) darbe naudojami kitokie, nei siūlomoje metodikoje, analizès metodai - atitinkamai modifikuotas momentų metodas ir hibridinis (momentų ir $[S]$ matricų metodų derinys), be to siūlomoje metodikoje neįvertinta trumpiklių, jungiančių gretimas meandrinio laidininko mikrojuosteles, įtaka. Pažymètina taip pat, kad papildomas parametrų ir charakteristikų skirtumas susidarè dèl to, kad sudarant MMVL modelį Sonnet ${ }^{\circledR}$ terpejje teko pasirinkti tokị analizuojamos srities žingsni, kad Sonnet ${ }^{\circledR}$ modelio ir sintezuotos MMVL topologijos matmenys skyrèsi apie $3 \%$.

Taigi, darytina išvada, kad siūlomoje MMVL sintezès metodikoje naudojamas matematinis modelis taikytinas projektuojant MMVL.

\subsubsection{Meandrinių mikrojuostelinių vèlinimo liniju lygiagrečiosios sintezès metodikos funkcionalumo tyrimas}

Siekiant išbandyti galimybes siūlomos metodikos sintezuoti ịvairių nominalių parametrų MMVL ir nustatyti gaunamų parametrų kartojimąsi buvo atlikti metodikos funkcionalumo tyrimai. Šiuose tyrimuose sintezuojant MMVL buvo 
nurodomos įvairios kombinacijos nominalių parametrų, tarkime, varijuojamas charakteringasis impedansas esant pastoviems vèlinimo trukmei ir praleidžiamųjų dažnių juostos pločiui arba keičiama nominali vẻlinimo trukmè nekeičiant charakteringojo impedanso ir praleidžiamujų dažnių juostos, ir pan. Sintezuojant MMVL tokiu būdu išbandyti abiejų tipų algoritmai - sintezè esant fiksuotam vèlinimo žingsniui ( $N=$ const) ir sintezè esant fiksuotam meandrinio laidininko ilgiui $\left(l_{m}=\right.$ const $)$.

5.2 lentelė MMVL sintezès metodikos, naudojant pirmojo tipo algoritmus, funkcionalumo tyrimo rezultatai*

Table 5.2. Results of the functionality research of MDML synthesis technique using algorithms of the first type *

\begin{tabular}{|c|c|c|c|c|c|c|c|c|c|}
\hline \multirow{2}{*}{ 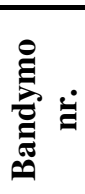 } & \multicolumn{3}{|c|}{$\begin{array}{l}\text { Nominalūs elekt- } \\
\text { riniai parametrai }\end{array}$} & \multicolumn{3}{|c|}{$\begin{array}{c}\text { Apskaičiuoti elektriniai } \\
\text { parametrai }\end{array}$} & \multicolumn{3}{|c|}{$\begin{array}{l}\text { Sintezuoti konstruk- } \\
\text { ciniai parametrai }\end{array}$} \\
\hline & $\begin{array}{c}Z_{0}, \\
\Omega\end{array}$ & $\begin{array}{l}t_{v}, \\
\mathrm{~ns}\end{array}$ & $\begin{array}{l}\Delta F, \\
\mathrm{GHz}\end{array}$ & $\begin{array}{c}Z_{0 \text { aps }} \\
\Omega\end{array}$ & $\begin{array}{c}t_{\text {vaps }}, \\
\mathrm{ns}\end{array}$ & $\begin{array}{c}\Delta F_{\text {aps }}, \\
\mathrm{GHz}\end{array}$ & $\begin{array}{l}W, \\
\mathrm{~mm}\end{array}$ & $\begin{array}{c}S, \\
\mathrm{~mm}\end{array}$ & $\begin{array}{l}2 A \\
\mathrm{~mm}\end{array}$ \\
\hline 1 & 50 & 3 & 1 & 50,82 & 3,02 & 1,01 & 0,80 & 0,60 & 8,05 \\
\hline 2 & 75 & 3 & 1 & 74,63 & 2,97 & 1,05 & 0,38 & 0,80 & 8,06 \\
\hline 3 & 120 & 3 & 1 & 119.95 & 3,01 & 1,01 & 0,11 & 0,80 & 8,41 \\
\hline 4 & 50 & 1 & 1 & 49,88 & 1,02 & 2,04 & 1,11 & 0.10 & 3,78 \\
\hline 5 & 50 & 2 & 1 & 49,06 & 1,99 & 1.05 & 1,14 & 0,10 & 7,35 \\
\hline 6 & 50 & 3 & 1 & 50,82 & 3,01 & 0,99 & 0,80 & 0,60 & 8,20 \\
\hline 7 & 50 & 4 & 1 & 48,69 & 3,92 & 1,02 & 0,73 & 1,30 & 9,26 \\
\hline 8 & 50 & 5 & 1 & 49,09 & 4,92 & 1,01 & 0,73 & 2,20 & 10,71 \\
\hline 9 & 50 & 1,5 & 0,5 & 49,06 & 1,49 & 1,41 & 1,13 & 0,10 & 5,49 \\
\hline 10 & 50 & 1,5 & 1 & 51,59 & 1,52 & 1,36 & 1,08 & 0,10 & 5,71 \\
\hline 11 & 50 & 1,5 & 1,5 & 52,41 & 1,52 & 1,50 & 0,98 & 0,20 & 5,14 \\
\hline 12 & 50 & 1,5 & 2 & 50,82 & 1,49 & 1,99 & 0,80 & 0,60 & 4,08 \\
\hline 13 & 50 & 1,5 & 2,5 & 49,18 & 1,52 & 2,46 & 0,73 & 1,10 & 3,69 \\
\hline 14 & 50 & 1,5 & 3 & 48,60 & 1,47 & 2,95 & 0,73 & 1,60 & 3,36 \\
\hline
\end{tabular}

* MMVL mikrojuostelių pločio $W$ kitimas - nuo $0,1 \mathrm{~mm}$ iki $1,3 \mathrm{~mm}$, žingsnis $\Delta W=$ $0,1 \mathrm{~mm}$; tarpo tarp mikrojuostelių $S$ kitimo ruožas - nuo $0,1 \mathrm{~mm}$ iki $2 \mathrm{~mm}$, žingsnis $\Delta S=0,1 \mathrm{~mm}$; meandrinio laidininko aukščio $2 A$ kitimo ruožas - nuo $1 \mathrm{~mm}$ iki 60 $\mathrm{mm}$, žingsnis $\Delta 2 A=1 \mathrm{~mm}$; mikrojuostelių pakopų skaičius $N=50=$ const 
5.3 lentelè. MMVL sintezès metodikos, naudojant antrojo tipo algoritmus, funkcionalumo tyrimo rezultatai*

Table 5.3. Results of the functionality research of MDML synthesis technique using algorithms of the second type *

\begin{tabular}{|c|c|c|c|c|c|c|c|c|c|c|c|}
\hline \multirow{2}{*}{ 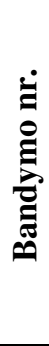 } & \multicolumn{3}{|c|}{$\begin{array}{c}\text { Nominalūs } \\
\text { elektriniai pa- } \\
\text { rametrai }\end{array}$} & \multicolumn{3}{|c|}{$\begin{array}{c}\text { Apskaičiuoti elektriniai } \\
\text { parametrai }\end{array}$} & \multirow{2}{*}{ 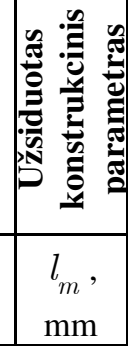 } & \multicolumn{4}{|c|}{$\begin{array}{l}\text { Sintezuoti konstruk- } \\
\text { ciniai parametrai }\end{array}$} \\
\hline & $\begin{array}{c}Z_{0}, \\
\Omega\end{array}$ & $\begin{array}{l}t_{v}, \\
\mathrm{~ns}\end{array}$ & $\begin{array}{l}\Delta F \\
\mathrm{GHz}\end{array}$ & $\begin{array}{c}Z_{0 \text { aps }}, \\
\Omega\end{array}$ & $\begin{array}{c}t_{v \text { aps }}, \\
\text { ns }\end{array}$ & $\begin{array}{c}\Delta F_{\text {aps }}, \\
\mathrm{GHz}\end{array}$ & & $\begin{array}{l}W, \\
\mathrm{~mm}\end{array}$ & $\begin{array}{c}S, \\
\mathrm{~mm}\end{array}$ & $\begin{array}{l}2 A \\
\mathrm{~mm}\end{array}$ & $N$ \\
\hline 1 & 50 & 3 & 1 & 50,82 & 2,92 & 1,08 & 69,4 & 0,80 & 0,60 & 8,12 & 49 \\
\hline 2 & 75 & 3 & 1 & 75,25 & 2,96 & 1,01 & 58,2 & 0,45 & 0,50 & 7,35 & 61 \\
\hline 3 & 120 & 3 & 1 & 119,34 & 3,09 & 0,98 & 44,7 & 0,17 & 0,50 & 7,38 & 67 \\
\hline 4 & 50 & 1 & 1 & 49,88 & 0,98 & 2,08 & 60,4 & 1,11 & 0,10 & 3,74 & 49 \\
\hline 5 & 50 & 2 & 1 & 49,88 & 2,03 & 1,04 & 61,9 & 1,11 & 0,10 & 7,39 & 51 \\
\hline 6 & 50 & 3 & 1 & 49,10 & 2,93 & 0,98 & 69,4 & 0,87 & 0,50 & 8,06 & 51 \\
\hline 7 & 50 & 4 & 1 & 51,01 & 3,92 & 1,01 & 100,2 & 0,73 & 0,80 & 7,63 & 66 \\
\hline 8 & 50 & 5 & 1 & 51,02 & 5,11 & 0,98 & 144,3 & 0,73 & 0,80 & 6,97 & 94 \\
\hline 9 & 50 & 1,5 & 0,5 & 50,75 & 1,50 & 1,40 & 61,4 & 1,10 & 0,10 & 5,49 & 51 \\
\hline 10 & 50 & 1,5 & 1 & 50,72 & 1,50 & 1,36 & 58,9 & 1,09 & 0,10 & 5,73 & 49 \\
\hline 11 & 50 & 1,5 & 1,5 & 51,51 & 1,50 & 1.52 & 58,8 & 0,99 & 0,20 & 5,14 & 49 \\
\hline 12 & 50 & 1,5 & 2 & 49,10 & 1,46 & 1,98 & 69,4 & 0,87 & 0,50 & 4,00 & 51 \\
\hline 13 & 50 & 1,5 & 2,5 & 51.02 & 1.46 & 2.53 & 90,4 & 0.73 & 0.80 & 3.18 & 59 \\
\hline 14 & 50 & 1,5 & 3 & 48,70 & 1,46 & 2,99 & 114,9 & 0,73 & 1,30 & 3,02 & 57 \\
\hline
\end{tabular}

* Meandrinio laidininko mikrojuostelių pločio $W$ kitimas - nuo $0,1 \mathrm{~mm}$ iki $1,3 \mathrm{~mm}$, žingsnis $\Delta W=0,1 \mathrm{~mm}$; tarpo tarp mikrojuostelių $S$ kitimo ruožas - nuo $0,1 \mathrm{~mm}$ iki 2 mm, žingsnis $\Delta S=0,1 \mathrm{~mm}$; meandrinio laidininko aukščio $2 A$ kitimo ruožas - nuo 1 $\mathrm{mm}$ iki $60 \mathrm{~mm}$, žingsnis $\Delta 2 A=1 \mathrm{~mm}$.

Sintezès metodikos funkcionalumo tyrimo rezultatai naudojant pirmojo tipo algoritmus ( $N=$ const) pateikti 5.2 lenteleje, o naudojant antrojo tipo algoritmus $\left(l_{m}=\right.$ const $)-5.3$ lentelèje.

5.2 ir 5.3 lentelèse pateikti duomenys iliustruoja MMVL sintezès algoritmų veikimą - kaip, varijuojant konstrukcinius vẻlinimo linijos parametrus, keičiasi jos elektriniai parametrai.

Tarkime, ieškomas charakteringasis impedansas pasiekiamas keičiant meandrinio laidininko mikrojuostelių plotị $W$ ir, reikalui esant, koreguojant tarpą tarp mikrojuostelių $S$. Pvz., mūsų atveju didinat ieškomą charakteringajị impedansą nuo $50 \Omega$ iki $120 \Omega$ (5.2 ir 5.3 lentelių $1-3$ bandymai), mikrojuostelès 
plotis buvo sumažintas apie $80 \%$, tarpas tarp mikrojuostelių pakito nedaugiau kaip $25 \%$, o meandrinio laidininko aukštis $2 A$ praktiškai nepasikeite.

Ieškoma vẻlinimo trukmé gaunama atitinkamai didinant arba mažinant meandrinio laidininko aukšti $2 A$. Atliktuose bandymuose (5.2 ir 5.3 lentelių 4-8 bandymai) didinant vèlinimo trukmę nuo $1 \mathrm{~ns}$ iki 5 ns aukšti $2 A$ teko padidinti iki $183 \%$. Pažymėtina, kad didinant $2 A$ didejja sąryšis tarp gretimų mikrojuostelių ir atitinkamai siaurèja praleidžiamujų dažnių juosta $\Delta F$. Siekiant praplèsti $\Delta F$ didinamas tarpas $S$, o mažèjantis dèl to charakteringasis impedansas didinamas siaurinant mikrojuosteles. Mūsų atveju 8-me bandyme $S$ teko padidinti net 22 kartus 4-to bandymo atžvilgiu ir $W$ atitinkamai sumažinti $34 \%$.

Pagal siūlomą metodiką MMVL siekiama praleidžiamųjų dažnių juosta $\Delta F$ gaunama varijuojant tarpą $S$ tarp meandrinio laidininko mikrojuostelių. Mūsų bandymuose (5.2 ir 5.3 lentelių 9-14 bandymai) sintezuojamų MMVL juosta $\Delta F$ buvo didinama nuo 0,5 iki $3,0 \mathrm{GHz} 0,5 \mathrm{GHz}$ žingsniu. Tarpas $S$ šiuo atveju padidèjo net 15 kartų. Dèl ženkliai didejjusio tarpo $S$ didejo vẻlinimo linijos efektinè dielektrinè skvarba, atitinkamai mažèjo sklindančių bangų fazinis greitis, didèjo vẻlinimo trukmè $t_{\mathrm{vzd}}$ ir mažèjo charakteringasis impedansas $Z_{0}$. Siekiant užsiduotu $t_{\mathrm{vzd}}$ ir $Z_{0}$ sintezuojamose linijose didejant $S$ buvo mažinamas meandrinio laidininko aukštis $2 A$, o charakteringasis impedansas didinamas siaurinant mikrojuosteles. Pvz., 14-me bandyme, 9-o bandymo atžvilgiu, sintezuojamoje MMVL $2 A$ buvo sumažintas $39 \%$, o mikrojuostelès susiaurintos $35 \%$.

\subsubsection{Meandrinių mikrojuostelinių vėlinimo linijų lygiagrečiosios sintezès algoritmų našumo tyrimas}

Siekiant ištirti siūlomų MMVL lygiagrečiosios sintezès algoritmų našumą buvo įrengtas 14-os kompiuterių bandomasis heterogeninis telkinys. Telkinyje naudojamų kompiuterių, parametrai pateikti 5.4 lentelëje.

Skaičiavimų apimties tolydumui užtikrinti, esant ịvairiam mazgų skaičiui telkinyje, visuose bandymuose pasirinktas vienodas procesų skaičius, atitinkantis didžiausią mazgų kiekị $p=14$.

Algoritmų našumo tyrimo rezultatai pateikti 5.8 pav. grafikuose. Pažymètina, kad MMVL sintezès trukmė naudojant algoritmus, grịstus skiltinio artèjimo metodu, nekinta kartojant bandymus esant tam pačiam mazgų telkinyje skaičiui, tuo tarpu sintezès trukmè naudojant Monte Karlo metodu grịstus algoritmus yra atsitiktinio pobūdžio. Tarkime, telkinyje, sudarytame iš 10 mazgų, didžiausia bandymuose užfiksuota sintezès trukmè, naudojant algoritmus, grịstus Monte Karlo metodu, buvo 1562 s, o mažiausia - 1112 s. Todèl buvo priimta kartoti 
MMVL sintezę naudojant algoritmus, grịstus Monte Karlo metodu, 10 kartų kiekvienam mazgų skaičiui telkinyje ir apskaičiuoti sintezès trukmès aritmetinị vidurkį.

5.4 lentelè. Kompiuterių, naudojamų bandomajame telkinyje, parametrai

Table 5.4. Parameters of computers which are used in the cluster

\begin{tabular}{|c|c|c|c|c|c|}
\hline $\begin{array}{c}\text { Kompiuteriu } \\
\text { telkinyje } \\
\text { skaičius }\end{array}$ & $\begin{array}{l}\text { Centrinis } \\
\text { procesorinis } \\
\text { įrenginys }\end{array}$ & $\begin{array}{l}\text { Darbinės } \\
\text { atminties } \\
\text { talpa, MB }\end{array}$ & $\begin{array}{l}\text { Standžiujjų } \\
\text { diskų kau- } \\
\text { piklio tal- } \\
\text { pa, GB }\end{array}$ & $\begin{array}{l}\text { Tinklo } \\
\text { korta }\end{array}$ & $\begin{array}{c}\text { Operacinė } \\
\text { sistema }\end{array}$ \\
\hline 6 & $\begin{array}{c}\text { Intel }^{\circledR} \text { Pen- } \\
\text { tium } 4^{\circledR} \\
2,8 \mathrm{GHz}\end{array}$ & 512 & 40 & $100 \mathrm{Mb} / \mathrm{s}$ & \multirow{3}{*}{$\begin{array}{l}\frac{1}{\pi} \\
\frac{\pi}{0} \\
\frac{0}{0} \\
\text { II }\end{array}$} \\
\hline 7 & $\begin{array}{c}\text { Intel }^{\circledR} \text { Pen- } \\
\text { tium } 4^{\circledR} \\
3,0 \mathrm{GHz}\end{array}$ & 1000 & 80 & $100 \mathrm{Mb} / \mathrm{s}$ & \\
\hline 1 & $\begin{array}{c}\text { Intel }^{\circledR} \text { Core } \\
2 \mathrm{Dou}^{\circledR} \\
2,8 \mathrm{GHz}\end{array}$ & 4000 & 160 & $1 \mathrm{~Gb} / \mathrm{s}$ & \\
\hline
\end{tabular}

Kompiuteriai telkinyje sujungti Ethernet vietiniu tinklu pagal žvaigždès topologiją, kurio didžiausias pralaidumas siekia $1 \mathrm{~Gb} / \mathrm{s}$.

Visi sintezès algoritmai ịgyvendinti $C$ programavimo kalba naudojant PSS funkcijomis.

Bandomajai sintezei pasirinktų MMVL nominalūs parametrai pateikti 5.5 lentelèje.

5.5 lentelè. Meandrinių mikrojuostelinių vèlinimo linijų, naudojamų lygiagrečiosios sintezès algoritmų našumo tyrimuose, parametrai

Tabale 5.5. Input parameters of the meander microstrip delay line which is used for the reseach of effectivenes of the algorithms of the parallel synthesis

\begin{tabular}{|c|c|c|c|c|c|}
\hline \multirow{2}{*}{$\begin{array}{c}\text { Algoritmo } \\
\text { tipas }\end{array}$} & \multicolumn{2}{|c|}{$\begin{array}{c}\text { Sintezę ribojantys pa- } \\
\text { rametrai }\end{array}$} & \multicolumn{3}{|c|}{ Elektriniai parametrai } \\
\cline { 2 - 6 } & $\begin{array}{c}\text { Pakopų } \\
\text { skaičius }\end{array}$ & $\begin{array}{c}\text { Meandrinio } \\
\text { laidininko } \\
\text { ilgis, mm }\end{array}$ & $\begin{array}{c}\text { Vèlinimo } \\
\text { trukme, } \\
\text { ns }\end{array}$ & $\begin{array}{c}\text { Praleidžiamų- } \\
\text { jų dažnių juos- } \\
\text { ta, MHz }\end{array}$ & $\begin{array}{c}\text { Charakterin- } \\
\text { gasis impe- } \\
\text { dansas, } \Omega\end{array}$ \\
\hline $\begin{array}{c}\text { Pirmojo } \\
\text { tipo algo- } \\
\text { ritmas }\end{array}$ & 55 & - & 6,72 & 364,00 & 61,50 \\
\hline $\begin{array}{c}\text { Antrojo } \\
\text { tipo algo- } \\
\text { ritmas }\end{array}$ & - & 54,65 & 6,53 & 354,00 & 62,20 \\
\hline
\end{tabular}




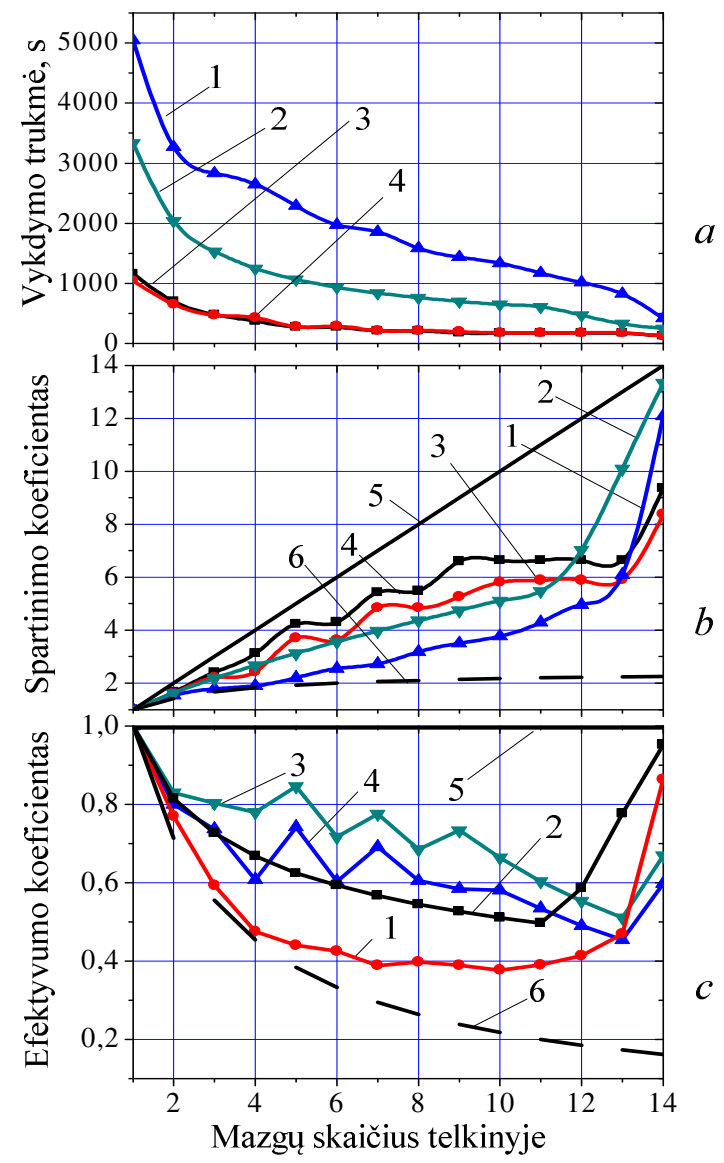

5.8 pav. Sintezès algoritmų vykdymo trukmè $(a)$, spartinimo koeficiento $(b)$ ir efektyvumo koeficiento $(c)$ priklausomybès nuo mazgų skaičiaus kompiuterių telkinyje. Čia 1 ir 2 - algoritmai, grịsti Monte Karlo metodu, esant, atitinkamai $N=$ const ir $l_{\mathrm{m}}=$ const ; 3 ir 4 - algoritmai, grịsti skiltinio artejjimo metodu, esant, atitinkamai $N=$ const ir $l_{\mathrm{m}}=$ const $; 5-$ idealus atvejis, kai $S_{p}=p ; 6$-teorinè priklausomybè, kai $r=0,6$ ir $s=0,4$

Fig. 5.8. Synthesis algorithm execution time response to the cluster nodes number $(a)$, scaliability $(b)$ and effectivenes $(c)$. Here is 1 and $2-$ algorithms based on Monte Carlo method, when $N=$ const and $l_{\mathrm{m}}=$ const ; 3 and 2 - algorithms based on successive aproximation method, when $N=$ const and $l_{\mathrm{m}}=$ const $; 5$-ideal case, when $S_{p}=p$; 6 - teorethycal case, when $r=0.6$ and $s=0.4$ 
5.8 pav. $a$ pateiktame grafike matyti, kad didinant mazgų skaičių kompiuterių telkinyje MMVL sintezès trukmė mažèja hiperboliniu dèsniu - tai bendras visų lygiagrečiụjų algoritmų bruožas (Čiegis 2005). Čia taip pat matyti, kad naudojant skiltinio artèjimo metodu grịstus algoritmus MMVL sintezė vyksta sparčiau esant bet kuriam mazgų skaičiui telkinyje. Pažymėtina, kad tik tuomet, kai mazgų skaičius tampa pakankamai didelis (mūsų atveju 14), tikimybė rasti Monte Karlo metodu artimiausias optimalios konstrukcinių parametrų vertes, esant mažam iteracijų skaičiui, didejja, ir visų algoritmų vykdymo trukmė šiuo atveju mažai skiriasi.

Sintezès algoritmų spartinimo koeficiento priklausomybės nuo mazgų telkinyje skaičiaus pateiktos 5.8 pav., $b$. Idealiu atveju didejjant mazgų skaičiui $p$, spartinimo koeficientas turi didèti tiesiškai $S_{p}(p)=p$ (Čiegis 2005). 5.8 pav., $b$ grafikuose matyti, kad kol mazgų nèra daug $(p<6)$, funkcija $S(p)$ mažai skiriasi nuo tiesès, tačiau toliau didejjant mazgų skaičiui, ji auga lečiau - grafikas pasiekia asimptotinị režimą - tolesnis mazgų skaičiaus didinimas nedaug sumažina sintezès trukmę. Tačiau, mazgų skaičiui artejjant prie 14 - bandymuose nustatyto fiksuoto procesų skaičiams - visų algoritmų spartinimo ir efektyvumo koeficientų vertès vèl pradeda didèti. Atkreiptinas dèmesys ị tai, kad skiltinio artẻjimo metodu grịstu algoritmų spartinimo koeficientas greičiau pasiekia asimptotinị režimą nei algoritmų, grịstų Monte Karlo metodu.

Lygiagrečiujų algoritmų efektyvumo koeficiento priklausomybės nuo mazgų skaičiaus pateiktos 5.8 pav., $c$. Šio paveikslo grafikuose matyti, kad algoritmų, grịstų Monte Karlo metodu, efektyvumo koeficientas didejjant mazgu skaičiui mažèja sparčiau nei algoritmų, grịstų skiltinio artẻjimo metodu.

Tiriant sintezès algoritmų, grịstų skiltinio artẻjimo metodu, našumą pastebèta, kad didinant mazgų skaičių telkinyje nuo 5 iki 6, nuo 7 iki 8 ir nuo 9 iki 10 MMVL sintezès trukmè nemažèja. Tai galima paaiškinti neracionaliu 14 procesų paskirstymu tarp mazgų, kai jų skaičius atitinka nurodytas vertes. Dèl šios priežasties 5.8 pav., $b$ ir $c$ grafikuose, atitinkamuose kreivèse susidarė pjūklo formos lūžiai.

Lygiagrečiuosius algoritmus sudaro dvi dalys: $r$ - algoritmo dalis, kurią galima apskaičiuoti lygiagrečiai ir $s=1-r$ yra likusioji algoritmo dalis, kurią galima apskaičiuoti tik nuosekliai (Čiegis 2005). Pagal Amdahlo dèsnị (Amdahl 1964) lygiagrečiojo algoritmo spartinimo koeficientas yra ịvertinamas nelygybe 
5.6 lentelè. Siūlomų MMVL sintezès algoritmų lygiagrečiųjų ir nuosekliụjų dalių dydžiai

Table 5.6. Values of parallel and sequential parts of the microstrip meander delay line sinthesys algoritms

\begin{tabular}{|c|c|c|}
\hline Algoritmas & $\begin{array}{c}\text { Lygiagrečioji } \\
\text { dalis, } \%\end{array}$ & $\begin{array}{c}\text { Nuoseklioji } \\
\text { dalis, } \%\end{array}$ \\
\hline $\begin{array}{c}\text { Monte Karlo metodu grịs- } \\
\text { tas algoritmas, kai } \\
N=\text { const }\end{array}$ & 60 & 40 \\
\hline $\begin{array}{c}\text { Monte Karlo metodu grịs- } \\
\text { tas algoritmas, kai } \\
l_{\mathrm{m}}=\text { const }\end{array}$ & 75 & 25 \\
\hline $\begin{array}{c}\text { Skiltinio artejimo metodu } \\
\text { grịstas algoritmas, kai } \\
N=\text { const }\end{array}$ & 80 & 20 \\
\hline $\begin{array}{c}\text { Skiltinio artejjimo metodu } \\
\text { grịstas algoritmas, kai } \\
l_{\mathrm{m}}=\text { const }\end{array}$ & 75 & 25 \\
\hline
\end{tabular}

$$
S_{p}(n) \leq \frac{1}{s+r / p}
$$

čia $p$ - mazgų skaičius telkinyje. Iš (5.4) nelygybės ir eksperimentiškai gautų $S_{p}(p)$ bei $E_{p}(p)$ priklausomybių (7.8 pav., $b$ ir $c$ ) galima nustatyti siūlomų algoritmų lygiagrečiųjų ir nuosekliųjų dalių dydžius (5.6 lentelè).

\subsection{Penktojo skyriaus išvados}

1. Šiame skyriuje pasiūlyti ir ịgyvendinti keturi lygiagretieji meandrinių mikrojuostelinių vėlinimo linijų (MMVL) sintezès algoritmai. Atlikus šių algoritmų patikrą nustatyta, kad jų vėlinimo trukmės priklausomybė nuo dažnio lyginant su identiškai modeliuotos linijos Sonnet ${ }^{\circledR}$ programinès įrangos terpèje, tesiskiria vos $10 \%$. Šis skirtumas atsiranda, dèl skirtingų skaitinių metodų taikomų siūlomuose algoritmuose ir Sonnet ${ }^{\circledR}$ programi- $^{-}$ nèje įrangoje, bei skirtingų modelių - disertacijoje nagrinėjamas modelis

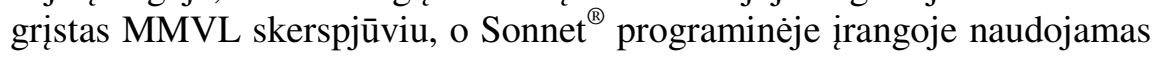
trimatis MMVL modelis.

2. Tyrimais nustatyta, kad didinant mazgų skaičių kompiuterių telkinyje visų siūlomų MMVL sintezès algoritmų vykdymo trukmė mažėja hiperboliniu dèsniu. 
- Sparčiausiai MMVL sintezė atliekama naudojant skiltinio artejjimo metodu grịstus algoritmus.

- MMVL sintezè pagal Monte Karlo metodu grịstus algoritmus vyksta bendruoju atveju léčiau, nes šiuose algoritmuose ieškomos vertès randamos atsitiktiniu būdu.

- Nustatyta, kad didžiausias visų siūlomų MMVL sintezės algoritmų efektyvumas pasiekiamas mazgų skaičiui telkinyje artejjant prie nustatyto procesų skaičiaus.

- Didžiausia lygiagrečiąja dalimi pasižymi skiltinio artėjimo metodu grịstas sintezès algoritmas, kai yra fiksuojamas meandro pakopų skaičius. Nustatyta, kad šio algoritmo lygiagrečiųjų skaičiavimų dalis sudaro $80 \%$. Mažiausia lygiagrečioji dalis yra Monte Karlo metodu grịstame algoritme, kai yra fiksuojamas meandro pakopų skaičius. Šio algoritmo lygiagrečiųų skaičiavimų dalis sudaro tik $60 \%$. 


\section{Bendrosios išvados}

Disertacijoje pasiūlytos ir išbandytos elektrodinaminių lètinimo įtaisų lygiagrečiosios analizės ir sintezès metodikos, sudarytos ir igyvendintos svarbiausios analizès ir sintezès priemonès - lygiagretieji algoritmai. Gautos šios elektros ir elektronikos inžinerijos mokslo krypčiai svarbios išvados:

1. Sukurti ir igyvendinti nereguliariujų t. y. baigtinio dydžio daugialaidžių mikrojuostelinių linijų (DML) matematiniai modeliai, atskleidžiantys dielektrinės terpės nevienalytiškumo ịtaką DML charakteristikoms. Kompiuteriniais eksperimentais pagrịsta, kad:

- sudarytieji modeliai teisingi, padarytos prielaidos leistinos, o naudojant sukurtają programinę ịrangą galima ịvertinti reiškinius baigtinio laidininkų skaičiaus daugialaidèse linijose ir padidinti DML elektrinių parametrų skaičiavimo tikslumą;

- dielektriko nevienalytiškumas iš esmès nekeičia krūvio pasiskirstymo pobūdžio DML skerspjūvyje. Dielektrinio pagrindo ịtaisymas vienalytėje daugialaideje linijoje didina krūvius visose mikrojuostelių skerspjūvio dalinèse srityse proporcingai pagrindo santykinei dielektrinei skvarbai;

- kraštinių ir vidinių mikrojuostelių charakteringieji impedansai skiriasi net iki 40 \% DML sužadinant lyginiu ir nelyginiu būdu. Charakte- 
ringojo impedanso verčių kitimas nuo kraštinių mikrojuostelių link vidinių yra didèjančio pobūdžio esant lyginiam sužadinimui, ir mažèjantis bei šiek tiek svyruojantis DML sužadinant nelyginiu būdu.

2. Pasiūlytas ir ịgyvendintas užduoties lygiagretinimo principu grịstas lygiagretusis DML, žadinamas lyginiu ir nelyginiu būdu, analizės algoritmas, leidžiantis sumažinti analizès trukmę iki 3,6 karto. Esant $N$ įmanomų DML žadinimo būdų skaičiui, pasiūlytas analizès algoritmas gali būti ịgyvendintas $2^{N}+1$ kompiuterių telkinyje.

3. Pasiūlytas ir igyvendintas duomenų lygiagretinimo principu grịstas DML sintezs algoritmas, leidžiantis sintezès trukmę mažinti proporcingai pavaldžiųjų kompiuterių skaičiui telkinyje. Pavaldžiųjų kompiuterių skaičius šiuo atveju gali siekti didžiausią ruožą tarp keičiamų konstrukcinių parametrų.

4. Pasiūlytas ir ịgyvendintas duomenų lygiagretinimo principu grịstas lygiagretusis meandrinès mikrojuostelinès vėlinimo linijos (MMVL) dispersinès charakteristikos apskaičiavimo algoritmas. MMVL dispersinès charakteristikos apskaičiavimo sparta pagal pasiūlytą algoritmą, igyvendinto 8 kompiuterių telkinyje, padidèjo beveik 4 kartus palyginus su skaičiavimais atliktais taikant tik vieną kompiuterį.

5. Sukurti ir igyvendinti keturi lygiagretieji MMVL sintezès algoritmai. $\mathrm{Nu}-$ statyta, kad:

- didinant mazgų skaičių kompiuterių telkinyje MMVL sintezės trukmè mažèja hiperbolinių dèsniu;

- sparčiausiai MMVL sintezė atliekama naudojant skiltinio artèjimo metodu gristus algoritmus;

- MMVL sintezè pagal Monte Karlo metodu grịstus algoritmus vyksta lèčiau, nes ieškomos vertès šiuose algoritmuose randamos atsitiktiniu būdu;

- pastebèta, kad didžiausias visų siūlomų MMVL sintezès algoritmų efektyvumas pasiekiamas mazgų skaičiui telkinyje artèjant prie nustatyto procesų skaičiaus. 


\section{Literatūra ir šaltiniai}

Adams, J. R.; Xu, Y.; Xu, X.; Choi, J. S.; Gedney, D. S. Canning, X. F. 2008. Modular fast direct electromagnetic analysis using local-global solution modes, in IEEE Antennas and Propogation Vol. 56: 2427-2441.

Almeida, F.; Gonzalez, D.; Morena, L. M. 2004. The master-slave paradigm on heterogeneous systems: a dynamic programming approach for the optimal mapping, in Parallel, Distributed and Network-Based Processings: 266-272.

$\mathrm{AMD}^{\circledR}$ - ATI stresam technology [interaktyvus] 2011 [žiūrèta 201109 12]. Interneto prieiga: < http://www.amd.com/US/PRODUCTS/TECHNOLOGIES/ STREAM-TECHNOLOGY/Pages/stream-technology.aspx>.

Amdahl, G. M. 1964. The structure of System/360, part III: processing unit design considerations, in IBM systems journal Vol. 3: 144-164.

Ansys $^{\circledR}$ - Simulation driven product development [interaktyvus] 2011 [žiūrèta 201109 12]. Interneto prieiga: <www.ansys.com>.

AWR - Microwave Office [interaktyvus] 2011 [žiūrèta 201109 12]. Interneto prieiga: < http://web.awrcorp.com/Usa/Products/Microwave-Office/>.

Bal, H. E.; Heines, M. 1998. Approaches for integrating task and data parallelism. In IEEE Concurency Vol. 6: 74-84. 
Betti, E.; Cesati, M.; Gioiosa, R.; Piemaria, F. 2009. A global operating system for HPC cluster, in IEEE Cluster computingand workshops CLUSTER '09: $1-10$.

Bogdanov, F. G.; Jobava, R.; Tsereteli, P. 2003. TriD: Tri-Dimensional code for electromagnetic modeling of arbitary surface and wire configurations, in User's Guide, ver. 2.14, EM Consulting and Software, Report No. D-0018: 4 p.

Boutboul M. S.; Kokabi H.; Pyée M. 1998. Modeling of microstrip quasi-TEM superconducting transmission lines, comparison with experimental results, in Physica C Vol. 309: 71-78.

Buchau, A.; Tsafak, S.M.; Hafla, W.; Rucker, W.M. 2008. Parallezation of Fast Multipole Boundry Element Method with cluster OpenMP, in Magnetics, IEEE Transactions on Vol. 44: 1338-1341.

Burokas, T.; Štaras, S. 2008. Properties of the Retard System Models Based on the Complex Cross Section Multiconductor Lines, in Electronics and Electrical Engineering No. 4(84): 3-8.

Chamarti, A.; Varahramyan, K. 2006. Transmission delay line based ID generation circuit for RFID applications, in IEEE Microwave and wireless components letters Vol. 16: 588-590.

Cheldavi A. 2003. Radiation from Multiconductor Transmission Lines: Exact Time-Domain Analysis, in Electromagnetics Vol. 23: 55-70.

Chen, X.; Cracraft, M.; Zhang, Y.; Zhang, J.; Drewniak, J.L. 2007. An efficient implementation of parallel FDTD, in Electromagnetic compatibility: 1-5.

Chen, Y.; Dinavahi, V. 2009. FPGA-Based real-time EMTP, in IEEE Power delivery Vol. 24: 892-902.

Chen, G. Y.; Sun, J. S.; Huang, S. Y.; Huang, C. J.; Wu, K. L.; Chen, Y. D.; Lin, C. H. 2006. The pliant monopole antenna (PMA) design for handset phone operation, in ISAPE '06: 1-4.

Chiang M. J.; Wu H. S.; Tzuang C. K. C. 2009. Artificial-synthesized edgecoupled transmission line for compact CMOS directional coupler designs, in IEEE Trans. Microave Theory Technology Vol. 57: 3410-3417.

$\mathrm{CST}^{\circledR}$ microwave studio ${ }^{\circledR}$ - 3D EM simulation software [interaktyvus] 2011 [žiūrèta 201109 12]. Interneto prieiga: <http://www.cst.com/Content/ Products/MWS/Overview.aspx>.

Nvidia $^{\circledR}$ [interaktyvus] 2011 [žiūrèta $2011 \quad 09$ 12]. Interneto prieiga: $<$ http://www.nvidia.com/object/cuda_home_new.html>. 
Čiegis R. 2005. Lygiagretieji algoritmai ir tinklinès technologijos. Vilnius: Technika. $321 \mathrm{p}$.

Davidovitz, M. 2002. Approach to model order reduction for angular response calculations in periodic structures, in Electronic letters Vol. 38: 357-358.

Daškevičius V.; Skudutis J.; Štaras S. 2007. Simulation and properties of the Hprofile meander system, in Electronics and Electrical Engineering No. 3: $65-68$.

Daškevičius, V.; Skudutis, J.; Štaras, S. 2007. Simulation of the inhomogeneous meander line, in Electronics and Electrical Engineering No. 2(74): 37-40.

emGine enviroment [interaktyvus] 2011 [žiūrèta 201109 12]. Interneto prieiga: $<$ http://www.petr-lorenz.com/emgine/>.

Ergul, O.; Malas, T.; Gurek, L. 2011. Analysis of dielectric photonic-crystal problems with MLFMA and Schur-complement preconditioners, in Journal Lightwave technology Vol. 29: 888-897.

Esposito, A.; Tarricole, L. 2003. Grid computing for electromagnetics: a begginner's guide with applications, in IEEE Antennas and Propogation Magazine Vol. 45: 91-100.

Farhat, C.; Roux, F. X. 1991. A Method of Finite Element Tearing and Interconnecting and its Parallel Solution Algorithm, in Int. J. Numer. Methods Eng Vol. 32: 1205-1227.

FEMLAB [interaktyvus] 2011 [žiūrèta 201106 16]. Interneto prieiga: $<$ http://www.math.chalmers.se/Math/Research/Femlab/>.

Feng, J.; Cheng, X. 2005. A study of parallel FDTD for simulating complex antennas on cluster system, in Microwave conference proceedings APMC 2005: $4 \mathrm{p}$.

Flynn, M. J. 1972. Some computer organizations and their effectiveness, in $I E$ EE transactions on computers: $4 \mathrm{p}$.

Flynn's taxonomy [interaktyvus] 2011 [žiūrèta 201106 16]. Interneto prieiga: $<$ http://en.wikipedia.org/wiki/Flynn\% 27s_taxonomy>.

Gao, B.; Gong, X.; Tong, L. 2009. Analysis of the Microstrip lines with finite substrate, in IEEE Circuits and system international conference ICTD 2009: $1-4$.

Geist, G. A.; Kohl, J. A.; Papadopoulos, P. M. 1996. PVM and MPI: a Comparison of Features, in Calculateurs Paralleles Vol. 8: 137-150. 
Gonzalez, J. M. V.; Barragan, C. A. B.; Jimenez, A. D.; Reatiga, A. G. A. 2010. Proof to verify the observation points in FDTD-MoL simulations of microstrip straight and menader lines, in International Journal of Microwave and Optical Technology Vol. 5: 22-26.

Grasso C.; Wu F. 2005. DDR SDRAM characteristic impedance and PCB design: how much impedance variation can a DDR SDRAM interface tolerate before going out of spec?, in Printed Circuit Design \& Manufacture, Thomson Gale Vol. 22. 22-33.

Greda, L. A.; Pregla, R. 2003. Mol - analysis of periodic structurs, in IEEE Microwave Symposoium Digest MTT-S Vol. 3: 1967-1970.

Gupta S.; Caloz C. 2009. Analog signal processing in transmminion line matematerial structures. Radioengineering Vol 18: 155-167.

Gupta, K. C.; Garg, R.; Chadha, R. 1981. Computer aided design of microwave circuits. Artech Hoese, Inc. 680 p.

Gurskas, A. 1995. Baigtiniu elementu metodo taikymas mikrojuostelinių daugialaidžių linijų paskirstytosioms talpoms skaičiuoti, in Electronic and electrotechnic No. 3(3): 56-60.

Gurskas, A.; Jurevičius, V.; Kirvaitis, R.; Šileikis, A. 2002. Application of Scattering Matrices in Investigation of Electrodynamic Systems, in Electronics and Electrical Engineering Vol. 4: 7-12.

Gurskas, A.; Urbanavičius, V.; Martavičius, R. 2010. Evaluation of the Microstrip Lines connectors in the Meander Delay Line model, in Elektronic ir electrotechnic No. 3(99): 39-42 p.

Hartley, D. R. T.; Catalyurek, U.; Ruiz, A. 2008. Biomedical image analysis on a cooperative cluster of GPU and multicores, in ICS '08: 15-25.

Han, L.; Wu, K.; Chen, X. P. 2009. Accurate Synthesis of Four-Line Interdigitated Coupler, in IEEE Transactions on MTT Vol. 57: 2444-2455.

Hashish, E. A.; Saker, H. A. 2003. Optimization of microstrip coupled lines band pass filters using the method of lines and the neurol network technique, in Radio Science Proceedings: 1-9.

Harrington, R. 1990. Origin and development of the method of moments for fieeld computation, in IEEE Antennas and Propogation Magazine Vol. 32: 31-35.

HFSS ANSYS [interaktyvus] 2011 [žiūrèta 201106 16]. Interneto prieiga: $<$ http://www.ansoft.com/products/hf/hfss/>. 
Intel $^{\circledR}$ Celeron $^{\circledR}$ [interaktyvus] 2011 [žiūrèta 201109 12]. Interneto prieiga: $<$ http://ark.intel.com/products/27104/Intel-Celeron-D-Processor-310-\%28256KCache-2_13-GHz-533-MHz-FSB\%29>.

Ishii, M.; Baba, Y. 2000. Advanced computational methods in lightning performance. The numerical electromagnetic code (NEC-2), in IEEE Power engineering sočiety Vol. 4: 2419-2424.

Iwashita, T.; Shimasaki, M. 2000. Parallel Processing of 3-D Eddy Current Analysis with Moving Conductor Using Parallelized nICCG Solver with Renumbering Process, in IEEE Trans. on Mag. Vol. 36: 1504-1509.

Iwashita, T.; Shimasaki, M. 2002. Algebraic Multicolor Ordering for Paralleized ICCG Solver in Finite-Element Analyses, in IEEE Trans. on Mag. Vol. 38: 429-432.

Iwashita, T.; Shimasaki, M. 2000. Parallel Solvers for Electromagnetic Field Computations on Printed Circuit Boards, in IEEE Trans. On Mag. Vol. 36: 1504-1509.

Janhsen, A.; Hansen, V. 1991. Determination of the Characteristic Impedance of Single and Coupled Lines in Layered Dielectric Media, in IEEE Microwave Symposium Digest Vol. 2: 765-768.

Jobava, R.; Tsereteli, P.; Bagdonov, F.; Rachenko, A. 2004. Solving large scale EMC problems using Linux cluster and parallel MoM, in Direct and inverse problems of electromagnetic and acoustic wave theory: 83-86.

Jobava, R.; Gheonjian, A.; Karkashadze, D.; Chikovani, G.; Bzhalava, A; Hippeli, J. 2010. Scattering of low frequency magnetic fields by thin 3D sheets with combined resistive and magnetic properties, in DIPED 2010: 103-109.

Kabiri, A.; Qing, H.; Kermani, M. H. 2010. Design of a controllable delay line, in IEEEAdvanced packaging Vol. 33: 1080-1087.

Karypis, G.; Kumar, V. 1995. Analysis of Multilevel Graph Partitioning, in Proceedings of $S C: 18 \mathrm{p}$.

Kelley, C. T. 1999. Iterative Methods for Optimization. Philadelphia: SIAM. $202 \mathrm{p}$.

Kirvaitis, R. 1994. Elektrodinaminès vélinimo linijos. Vilnius: Technika. 216 p.

Kitano, M. 2009. The Vacuum impedance and unit system, in IEICE Transacton on Electronics Vol. E92. C: 3-8. 
Kleiza A.; Štaras, S. 1999. Calculation of Characteristic Impedance of Multiconductor Lines, in Electronics and Electrical Engineering Vol. 4: 41-44.

Kowalski, G. 1974. Coplanar printed meander lines, in AEU B.28.H.6: 257-262.

Krukonis, A. 2010. Investigation of calculation techniques of finite difference method, in Science - Future of Lithuania Vol. 2: 103-107.

Kuylenstierna, D.; Gunnarsson, S. E.; Zirath, H. 2005. Lumped-element quadrature power splitters using mixed right/left-handed transmission lines, in IEEE Microwave Theory and Techniques Vol. 53: 2616-2621.

Kumpel, W.; Effing, U.; Rittweger, V; Wolff, I. 1993. Parallel FDTD simulator for microwave structures, in 23rd European microwave conference: 676-677.

LAACG - Description ARGUS [interaktyvus] [žiūrèta 201106 16]. Interneto prieiga: <http://laacg1.lanl.gov/laacg/c-on-line/descriptions/argus.html>.

Lee H. M.; Tsai C. M. 2009. Exact synthesis of broadband three-line Baluns, in IEEE Trans. Microw. Theory Tech. Vol. 57: 140-148.

Lemona [interaktyvus] 2011 [žiūrèta 201109 12]. Interneto prieiga: $<$ http://www.lemona.lt/index.php?page=item\&i_id=d1bb7259bb603fe36d877e7 $1 \mathrm{c} 5 \mathrm{c} 1 \mathrm{e} 048>$.

Losito, O. 2007. A double taered microstrip leaky wave antena, in EuCap 2007: $1-6$.

Lucca, G. 2000. Per unit length parameters of a multiconductor line with earth return inside a tunnel, in IEEE Transactions on Electromagnetic Compatibility Vol. 42: 6-15.

Mafia 4 [interaktyvus] 2011 [žiūrèta 201109 12]. Interneto prieiga: < http://www.cst.com/Content/Products/MAFIA/Overview.aspx>.

Maloratsky, G. L. 2011. Using modified microstrip lines to improve circuit performance, in High frequency Electronics: 36-52.

Marrocco, G. Gain-optimized self-resonant meander line antenas for RFID applications, in IEEE Antennas and wireless propogation letters Vol. 2: 302-305.

Martavičius, R.; Jurjevas, A. 2000. Broadband Microstrip Meander Retard Systems (RS) Properties, in Electronics and Electrical Engineering Vol. 5: 43-48.

Martavičius, R.; Jurjevas, A. 2001. Patikslinti plačiajuosčių meandrinių lètinimo sistemų modeliai, in Electronic and electrotechnic No. 5(34): 38-43.

Martavičius, R.; Urbanavičius, V. 1996. Netolygaus žingsnio daugialaidès linijos, in Elektronic ir electrotechnic No. 4(8): P. 24-30. 
Martavičius, R.; Urbanavičius, V. 2004. Comparative analysis of the meander delay lines. In Proceedings of the XIV international conference on electromagnetic disturbances: 195-200.

Martavičius, R., Urbanavičius, V. 2002. The method of calculation of linear capacitances of the multiconductor line with irregular step, in Electronics and Electrical Engineering Vol. 6: 47-53.

Martavicius, R 1996. Electrodynamic plain retard systems for the wide-band electronic devices. Vilnius: Technika. 264 p.

Masot, F.; Medina, F.; Horno, M. 1994. Analysis and experimental validation of a type of three-microstrip directional coupler, in IEEE Transactions on MTT Vol. 42: 1624-1631.

Mentor Graphics [interaktyvus] 2011 [žiūrèta 201106 16]. Interneto prieiga: $<$ http://www.mentor.com/electromagnetic-simulation/solutions $>$.

Mikučionis, Š.; Urbanavičius, V. 2010. Synthesis of Microstrip Multiconductor Lines, Operating in Normal Mode, in 18th International Conference on Microwave, Radarand Wireless Communications MIKON-2010: 353-356.

MPICH2: High-performance and widely portable MPI [interaktyvus] 2011 [žiūrèta $2011 \mathrm{~m}$. 17]. Interneto prieiga: <http://www.mcs.anl.gov/research/projects/ mpich2/>.

Murray-Shelley, R. 1969. Calculation of transients on unsymmetrical multiconductor line systems using the graphical method, in Electronics Letters Vol. 5: 316-317.

Navsariwala, U. D.; Gedney, S. D. 1997. An Efficient Implementation of the Finite-Element Time Domain algorithm on parallel Computers using a FiniteElement Tearing and Interconnecting Algorithm, in Microwave and Optical Technology Letters Vol. 16: 204-208.

$\mathrm{Ng}$, G.; Chan, A. C. 2008. A 38-Gb/s 2-tap transversal equalizer in 0,13- $\mu \mathrm{m}$ CMOS using a microstrip delay element, in Radio frequency integrated circuit symposium: 207-210.

Nickelson, L.; Shugoroff, V. 2005. Singular integral equations' methods for the analysis of microwave structures. Leiden\&Boston: VSP. 330 p.

Nikfal, B.; Gupta, S.; Caloz, C. 2011. Increased group-delay slope loop system for enhanced-resolution analog signal processing, in IEEE Microwave theory and techniques Vol. 59: 1622-1628. 
Oguni, N. Aasai, H. 2008. Estimation of parallel FDTD-based electromagnetic field solver on PC cluster with multi-core CPUs, in Advanced Packaging and Systems Symposium: 159-162.

Pacheco, P. S. 1996. Parallel Programming with MPI. San Francisco: Morgan Kaufman Publishers. 500 p.

Park S. W.; Ju J. C.; Park D. C. 2005. Analysis of Crosstalk between FiniteLength Multiconductor Transmission Lines on a PCB by Using Circuit-Concept Approach, in IEICE Transactions on Communications Vol. E88-B, No 8: 3189-3194.

Paul, C. R. 2008. Analysis of Multiconductor Transmission Lines. John Wiley \& Sons. $803 \mathrm{p}$.

Pierce, J. R. 1950. Traveling Wave Tubes. New York: Van Nostrand. 260 p.

Preradovic, S.; Balbin, I.; Karmakar, N. C.; Swiegers, F. G. 2009. Multiresonator-Based chipless RFID system for Low-cost item tracking, in IEEE Microwave theory and techniqes Vol. 57: 1411-1419.

Rachidi F.; Nucci C. A.; Ianoz W.; 1999. Transient analysis of multiconductor lines above a lossy ground, in IEEE Transactions on Power Delivery Vol. 14: 294-302.

Rawat, K.; Ghannouchi, F. M. 2009. A design methodology for miniaturized power deviders using periodically loaded slow wave structure with dual-band applications, in IEEE Trans. Microw. Theory Tech. Vol. 57: 3380-3388.

Robat, C. 2007. Introduction to super computers [interaktyvus]. [Žiūrèta 201109 16 d.] . Internet prieiga: < http://www.thocp.net/hardware/ supercomputers.htm>.

Rowe, J. E. 1956. A Large-Signal Analysis of the Traveling Wave Amplifier Theory and General Results, in IRE Transactions on Electron Devices Vol. ED-3: 39-57.

SAIC products [interaktyvus] 2011 [žiūrèta 201109 12]. Interneto prieiga: <http://www.saic.com/products/software/michelle/>.

Savenko, P. O.; Tkach, M. D. 2000. Numerical solution of synthesis problem of flat microstrip antenna array according to the prescribed power directivity pattern, in DIPED-2000 Proceedings: 74-79.

Sadiku, N. O. 2009. Numerical techniques in electromagnetics with MATLAB. CRC press. $648 \mathrm{p}$. 
Sakakibara, K.; Kashino, Y.; Hayashi, Y.; Kikuma, N.; Hirayama, H. 2007. Two dimensional array design techniques of millimeter-wave microstrip comb-line antenna array, in Radio science Vol. 43: 4 p.

Sarkar, A.; Benabbou, N.; Ghanem, R.; 2006. Domain decomposition method of stochastic PDEs and its parallel implementation, in HPC in an advanced collaboratyve enviroment: $17-17$.

Schneider, M. V. 1972. Microstrip dispersijon, in IEEE proceedings Vol. 60: 144-146.

Semcad X solution [interaktyvus] 2011 [žiūrèta $2011 \mathrm{~m} .09$ 21]. Interneto prieiga: <http:// http://www.speag.com/products/semcad/solutions/>.

Seshima, N.; Tanaka, M.; Tsuboi, H. 2006. Electromagnetic field analysis by using parallel processing based on OpenMP, in IEEE Electromagnetic field computation 12: $114 \mathrm{p}$.

Shafai, C.; Sharma, S. K.; Yip, J.; Shafai, L. 2008. Microstrip delay line phase shifter by actuating integrated ground plane membranes, in Microwave, Antenas \& Propagation, IET: 163-170.

Sheng, X. Q.; Yung, E. K. N.; Chan, C. H. 2001. Parallel Electromagnetic Modeling of 3D Microstrip Discontinuities using FEM and PML, in International Journal of RF and Microwave Computer-Aided Engineering Vol. 11: 38-47.

Shufeng S.; Junmei F. 2003. Analysis of pulsed signal distortion in microstrip line using Wigner-Ville distribution, in IEEE Antennas, propagation and EM theory. Proceedings. 862-865.

Skudutis, J.; Daškevičius, V. 2006. Investigation of meander delay system properties using the „MicroWave Studio“ software package, in Elektronic ir electrotechnic No. 8(72): 11-14 p.

Sonnet suties - Sonnet software [interaktyvus] 2011 [žiūrèta 201109 12]. Interneto prieiga: < http://www.sonnetsoftware.com/products/sonnet-suites/>

SPARC T3 microprocessor [interaktyvus] 2011 [žiūrèta 201109 12]. Interneto prieiga: < http://www.oracle.com/us/products/servers-storage/servers/sparcenterprise/t-series/sparc-t3-chip-ds-173097.pdfOverview.aspx>.

Steindl, R.; Pohl, A.; Reindl, L.; Seifert, F. 1998. SAW delay lines for wirelessly requestable conventional sensors, in IEEE Ultrasonics Sympoiums Proceedings Vol. 1: 351-354.

Sunderam, V. S.; Geist, G. A. 1999. Heterogeneous Parallel and Distributed Computing, in Parallel Computing Vol. 25: 1699-1721. 
Štaras, S.; Skudutis, J.; Daškevičius, V. 1998. Asimetriškai išdėstytos išoriniame ekrane spiralès tyrimas, in Electronic and electrotechnic No. 1(4). 35-36 p.

Štaras, S. 2008. Ivadas i skaitmeninius elektrodinamikos metodus ir ju taikyma. Technika: Vilnius. $185 \mathrm{p}$.

Štaras, S. 2005. Simulation and Properties of the Shielded Twined Helical Deflecting System, in IEEE Transactions on Electron Devices Vol. 52: 1222-1225.

Štaras, S.; Katkevičius, A.; 2010. Properties of helical structures containing periodical inhomogeneities, in Electronic and Electrotechnic No. 3(99): 49-52.

Štaras, S.; Martavičius, R.; Skudutis, J.; Urbanavičius, V.; Daškevičius, V. 2010. Plačiajuosčiu letinimo ịtaisu modeliavimas ir taikymas. Vilnius: Technika. $441 \mathrm{p}$.

Terada, T.; Ide, K.; Iwata, K.; Fukusako, T. 2008. Radiation characteristics of small and low profile print antena using peano line, in IEEE Microwave Conference APMC 2008: 1-4.

Teukolsky, S. A.; Vetterling, W. T.; Flannery, B. P. 1999. Numerical Recipes in $C$, The Art of Scientific Computing. Cambridge: Cambridge University Press. $1002 \mathrm{p}$.

Tharp, J. S.; Lopez-Alonso, J. M.; Ginn, J. C.; Lail, B. A.; Munk, B. A.; Boreman, G. D. 2006. Demonstration of a single layer meander line phase retarder at IR, in IEEE Antennas and propogation Society international symposium: 829-832.

Top 500 supercomputing site [interaktyvus] 2011. [žiūrèta 2011 rugsèjo 8 d.]. Interneto prieiga: <http://www.top500.org>.

Tripathi, V. k.; Lee, H. 1989. Spectral-domaincomputation of characteristic impedances and multiport parameters of multiple coupled microstrip lines, in IEEE Microwave theory and techniques Vol. 37: 215-221.

Urbanavičius, V.; Gurskas, A.; Martavičius, R. 2009. Simulation of the meander delay line using the hybrid method, in Electronics and Electrical Engineering No. 2(90): 3-6.

Urbanavičius, V.; Martavičius, R. 2006. Model of the microstrip line with a non-uniform dielectric, in Electronic and Electrotechnic No. 3(67). 55-60 p.

Urbanavičius, V.; Mikučionis, Š.; Martavičius, R. 2007. Model of the coupled transmission line with a non-uniform dielectric, in Electronics and Electrical Engineering No. 5 (77): 23-28. 
Vainoris, Z. 2004. Bangu elektronikos pagrindai. Vilnius: Technika. 513 p.

Vincent, P.; Culver, J.; Eason, S. 2003. Meandered line microstrip filter with suppression of harmonic passband response, in IEEE MTT-S International Microwave Symposium Digest: 1905-1908.

De Vivo, B.; Petrarca, C.; Tucci, V.; Vitelli, M. 2006. A multi conductor transmission line model for the evaluation of the rotor shaft voltages in adjustable speed drive motors, in Progress In Electromagnetics Research Symposium: 236-240.

Vollaire, C.; Nicolas, L.; Nicolas, A. 1998. Parallel Computing for the Finite Element Method, in The European Physical Journal Applied Physics, Vol. 1: 305-314.

Vollaire, C.; Nicolas, L.; Nicolas, A. 1998. Parallel Computing for Electromagnetic Field Computation, in IEEE Trans. on Mag. Vol. 34: 3419-3422.

Wang, H.; Xue, Z.; Gao, B.; Yang, S.; Li, W.; Ren, W. 2005. Analysis of the radiated characters pf phased-array antennas under the influence of shelter by parallel FDTD algorithm, in IEEE Microwave Conference proceedings: $4 \mathrm{p}$.

Wang, H.; Trakic, A.; Xia, L.; Crozier, S.; Liu, F.; Bialkowski, M. 2006. A parallel FDTD scheme for electromagnetic analysis and design of MRI system, in IEEE Eng. Med. Biol. Soc.: 264-267.

Wang, Q.; Yao, J. 2007. Switchable optical UWB monocycle and doublet generation using a reconfigurable photonic microwave delay-line filtre, in Optic Express Vol. 15: 667-672.

Weiss, J. A.; Bryant, T. G. 1969. Parameters of microstrip, in Electronic letters Vol. 5: 517 p.

Wei, C.; Barrington, R. F.; Mautz, J. R.; Sarkar, T. K. 1984. Multiconductor transmission lines in multilayered dielectric media, in IEEE Microwave theory and techniques Vol. 32: 439-450.

Wheeler, H. A. 1964. Transmission-line properties of parallel wide strips by a conformal-mapping approximation, in IEEE Microwave theory and techniques Vol. 12: 280-289.

Wolfe, C. T.; Navsariwala, U.; Gedney, S. D. 2000. A parallel Finite- Element Tearing and Interconnecting Algorithm for Solution of the Vector Wave Equation with PML Absorbing Medium, in IEEE Trans. on Antennas and Propagation Vol. 48.: 278-284. 
Yordanov, H.; Ivrlac, M.; Nossek, J.; Russer, P.; 2007. Field Modelling of a Multiconductor Digital Bus, in Proceedings of the 37th European Microwave Conference: $1377-1380$.

Zhang, Y.; Sarkar, T. K.; De, A.; Yilmazer, N.; Burintramart, S.; Taylor, M. 2007. A Cross-platform parallel MoM code with ScaLAPAC solver, in IEEE Antennas \& propogaton sočiety international symposium: 2797-2800.

Zhang, Y.; Sarkar, T. K.; Van De Geinjn, R. A.; Taylor, M. 2008. Parallel MoM using higher order basis function and PLAPACK in-core and out-of-core solvers for challenging EM simulations, in IEEE Antennas and Propagation Society International Symposium: 1-4.

Zhang, Y.; Ding, W.; Liang, C. 2005. Analysis of parallel performance of MPI based parallel FDTD on PC clusters, in Microwave Conference Proceedings APMC 2005 proceedings Vol. 4: $3 \mathrm{p}$.

Zhang, X.; Liu, X.; Liu, S.; Yu, J.; Ding, R.; Liu, B.; Xiao, R. 2008. A more efficient mechanism of FDTD method based on message passing interface, in Microwave and Millimeter Wave Technology. ICMMT 2008 Vol. 2: 692-695.

Zhang, Y.; Porter, J.; Taylor, M.; Sarkar, T. K. 2008. Solving challenging electromagnetic problems using MoM and a parallel out-of-core solver on high performance clusters, in IEEE Antennas and Propagation Society international symposium: $1-4$.

Zhang, Y.; Zhao, X. W.; Donoro, D. G.; Ting, S. W.; Sarkar K. T. 2010. Parallelized hybrid method with higher-order MoM and PO for analysis of phased array antenas on electrically large platforms, in IEEE Antennas and Propogation Vol. 58: 4110-4115.

Zingg D. W. 1997. High-order finite-difference methods in computationalelectromagnetics, in IEEE Antennas and Propagation Society International Symposium Vol. 1: 110-113.

Xiao, B.; Wang, X.; Zhao, J.; Zhang, D. 2010. Compact ultra-wideband printed monopole antena with a trapezoidal radiator, in ICISE 2010: 1919-1922.

Xillinx ${ }^{\circledR}$ FPGA's [interaktyvus] 2011 [žiūrèta 201109 12]. Interneto prieiga: $<$ http://www.xilinx.com/products/silicon-devices/fpga/index.htm>.

Гурскас, А. 1991. Исследование и разработка меандровых микрополосковых линии задержки. Диссертация на соискание научной степени кандидата технических наук. Вильнюс. 130 с. 
Кравцов. Ю. А. 2011. Нормальные волны, в Большой Советской Энциклоnедии [interaktyvus]. [Žiūrèta $2011 \quad 09 \quad 16$ d.] . Interneto prieiga: $<$ http://bse.scilib.com/article082603.html>.

Силин, Р. А.; Сазанов, В. П. 1966. Замедляюшие системы. Масква: Техника. $308 \mathrm{c}$.

Тараненко, 3. И.; Трохименко, Я. К. $\quad$ 1965. Замедляющие системы. Киев. 307 с.

Вайнорис, 3.; Кирвайтис, Р.; Штарас, С. 1986. Электродинамические задерживающие и отклоняющие системы. Вильнюс: Мокслас. 266 с.

Вержбицкий, В. 2001. Численный методы. математический анализ и обыкновенные дифференциальные уравнения. Москва: Оникс. 400 с. 



\section{Autoriaus publikacijos disertacijos tema}

\section{Straipsniai recenzuojamuose mokslo žurnaluose}

Pomarnacki, R. 2010. Dispersinès lygties sprendimo būdai, Mokslas - Lietuvos ateitis. 2(1): 112-116. Vilnius: Technika. ISSN 2029-2341 (Index Copernicus).

Pomarnacki, R.; Krukonis, A.; Urbanavičius, V. 2010. Parallel algorithm for the quasiTEM analysis of microstrip multiconductor line, Elektronika ir elektrotechnika. 5(101): 86-89. Kaunas: Technologija. ISSN 1392-1215 (ISI Web of Science).

Pomarnacki R.; Krukonis A. 2011. Parallel synthesis of multiconductor microstrip lines, Mokslas - Lietuvos ateitis. 3(1): 104-109. Vilnius: Technika. ISSN 2029-2341 (Index Copernicus).

\section{Straipsniai kituose leidiniuose}

Pomarnacki, R.; Urbanavičius, V. 2009. Parallel system for the analysis of meander delay line, in the $32^{\text {th }}$ international conference "IC-SPETO 2009". 53-54. Inspec.

Urbanavičius, V.; Pomarnacki, R. 2008. Models of multiconductor line with a nonhomogeneous dielectric, in the $18^{\text {th }}$ international conference "Electromagnetic disturbances EMD“2008”. 203-208 (ISI Proceedings). 



\section{Priedai}

\section{A priedas. Baigtinių skirtumų metodu gristas daugialaidès mikrojuostelinès linijos matematinis modelis}

Specifinis daugialaidès linijos nevienalyteje terpeje atvejis $-N$ juostelių daugialaidè mikrojuostelinè linija (DML), kurios apibendrinta sandara pateikta 2.1 pav.

Sudarydami matematinị DML modelị, grịstą baigtinių skirtumų (BS) metodu, galima remtis trečiaja Maksvelio lygtimi diferencialine forma (Vainoris 2004):

$$
\operatorname{div} \vec{D}=\rho(x, y, z),
$$

čia $\operatorname{div} \vec{D}$ - elektrinio lauko indukcijos vektoriaus $\vec{D}$ divergencija; $\rho$ - laisvojo elektros krūvio tankis taške su koordinatėmis $x, y, z$.

Atsižvelgus į tai, kad

$$
\vec{D}=\varepsilon_{0} \varepsilon_{\mathrm{r}} \vec{E}
$$




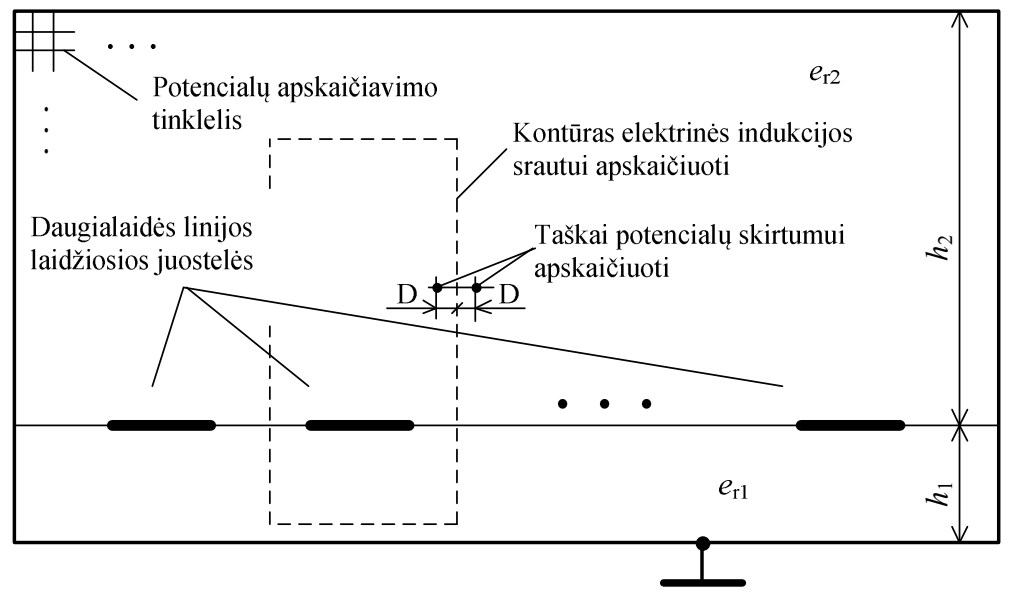

$\mathrm{a}$

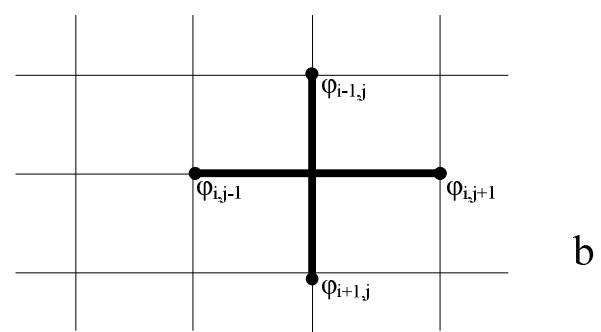

A1.1 pav. Daugialaidès mikrojuostelinès linijos modelio, grịsto Baigtinių skirtumų metodu skerspjūvis (a) ir potencialų apskaičiavimo tinklelio fragmentas (b)

ir

$$
\vec{E}=-\operatorname{grad} \varphi
$$

(A1.1) lygti galima perrašyti taip:

$$
\operatorname{div} \operatorname{grad} \varphi=-\frac{\rho(x, y, z)}{\varepsilon_{0} \varepsilon_{\mathrm{r}}},
$$

čia $\vec{E}$ - elektrinio lauko stiprio vektorius; $\varphi$ - elektrinis potencialas, $\varepsilon_{0}$ - elektrinè konstanta, $\varepsilon_{\mathrm{r}}-$ santykinė dielektrinè skvarba.

Pastaroji lygtis vadinama Puasono (Poisson) lygtimi. Stačiakampèje koordinačių sistemoje Puasono lygtis išreiškiama šitaip: 


$$
\frac{\partial^{2} \varphi}{\partial x^{2}}+\frac{\partial^{2} \varphi}{\partial y^{2}}+\frac{\partial^{2} \varphi}{\partial z^{2}}=-\frac{\rho(x, y, z)}{\varepsilon}
$$

arba

$$
\nabla^{2} \varphi=-\frac{\rho(x, y, z)}{\varepsilon}
$$

čia $\nabla^{2}$ - Laplaso operatorius

$$
\nabla^{2}=\frac{\partial^{2}}{\partial x^{2}}+\frac{\partial^{2}}{\partial y^{2}}+\frac{\partial^{2}}{\partial z^{2}} .
$$

Kai tarp laidininkų nėra laisvųjų krūvių $(\rho=0)$, Puasono lygtis tampa paprastesnè - igyja Laplaso lygties pavidalą. Tada dvimatės erdvės atveju

$$
\frac{\partial^{2} \varphi}{\partial x^{2}}+\frac{\partial^{2} \varphi}{\partial y^{2}}=0
$$

Dalines potencialo išvestines (A1.8) lygtyje galime išreikšti baigtiniais potencialų skirtumais (Sadiku 2009, Štaras et al. 2010). Nagrinejjamą sritį reikia padalinti tinkleliu. Analizuojant dvilaides ir daugialaides linijas gerai tinka tolygus dekartinis tinklelis, kurio taškų koordinates apibūdina sveikieji skaičiai $i, j$ (A1.1 pav., $b$ ). Tolygiam tinkleliui dalinimo žingsnis $x$ ir $y$ kryptimis yra vienodas:

$$
\begin{gathered}
x_{i+1}-x_{i}=x_{i}-x_{i-1}=\Delta x, \\
y_{j+1}-y_{j}=y_{j}-y_{j-1}=\Delta y,
\end{gathered}
$$

čia $\Delta x=\Delta y=\Delta$.

Potencialą taške $i, j$ pažymėję $\varphi_{i, j}$, potencialo pokyti tarp gretimų $x$ kryptimi taškų $i, j$ ir $i+1, j$, galime išreikšti taip:

$$
\frac{\partial \varphi}{\partial x} \cong \frac{\varphi_{i+1, j}-\varphi_{i, j}}{\Delta}
$$

o tarp taškų $i, j$ ir $i-1, j$ : 


$$
\frac{\partial \varphi}{\partial x} \cong \frac{\varphi_{i, j}-\varphi_{i-1, j}}{\Delta}
$$

Tada antrosios eilès išvestinè

$$
\frac{\partial^{2} \varphi}{\partial x^{2}} \cong \frac{\left(\varphi_{i+1, j}-\varphi_{i, j}\right) / \Delta-\left(\varphi_{i, j}-\varphi_{i-, j}\right) / \Delta}{\Delta}=\frac{\varphi_{i+1, j}+\varphi_{i-1, j}-2 \varphi_{i, j}}{\Delta^{2}} .
$$

Analogiškai gauname antrosios eilès išvestinès išraišką $y$ koordinatės kryptimi:

$$
\frac{\partial^{2} \varphi}{\partial y^{2}} \cong \frac{\varphi_{i, j+1}+\varphi_{i, j-1}-2 \varphi_{i, j}}{\Delta^{2}} .
$$

Gautąsias antrụjų išvestinių išraiškas (A1.13) ir (A1.14) įrašę i dvimatę Laplaso lygtị (A1.8) gauname:

$$
\varphi_{i+1, j}+\varphi_{i-1, j}+\varphi_{i, j+1}+\varphi_{i, j-1}-4 \varphi_{i, j}=0 .
$$

Pastaroji išraiška yra Laplaso lygtis, užrašyta skirtuminiu pavidalu. Iš jos gauname:

$$
\varphi_{i, j}=\left(\varphi_{i+1, j}+\varphi_{i-1, j}+\varphi_{i, j+1}+\varphi_{i, j-1}\right) / 4 .
$$

Pagal pradinius ir nekintamus (pavyzdžiui, linijos laidininko ir ekranų) potencialus, taikant (A1.16) ir sprendžiant iteracijomis, galima rasti potencialo pasiskirstymą visoje nagrinejjamoje srityje (linijos skerspjūvyje). Nagrinėjant potencialų pasiskirstymus vienlaidès, dvilaidžiu arba daugialaidžių linijų skerspjūviuose, patogiausia laidininkų potencialus prilyginti $1 \mathrm{~V}$, o ekranų (elektrinių sienelių) potencialus $-0 \mathrm{~V}$.

Kai linijos skerspjūvis užpildytas nevienalyčiu dielektriku, dielektrikų riboje potencialų skaičiavimo išraišką (A1.16) taip pat reikia koreguoti. Šiuo atveju linijos skerspjūvis padalinamas tinkleliu taip, kad dalis mazgų atsirastų dielektrikų riboje. Sakydami, kad nagrinėjamoje dvimatèje erdvejje nėra laisvujjų krūvių, užrašome Gauso dėsnị diferencialine forma:

$$
\frac{\partial D_{x}}{\partial x}+\frac{\partial D_{y}}{\partial y}=0,
$$

čia $D_{x}$ ir $D_{y}$-elektrinès indukcijos dedamosios $x$ ir $y$ ašių kryptimis.

Elektrinès indukcijos normalès kitimo greitị, pereinant dielektrikų ribą $y$ ašies kryptimi, galime išreikšti per taškų potencialus: 


$$
\begin{gathered}
\frac{\partial D_{y}}{\partial y}=\frac{D_{i, j+1 / 2}-D_{i, j-1 / 2}}{\Delta}= \\
=-\frac{\varepsilon_{0}}{\Delta^{2}}\left[\varepsilon_{\mathrm{r} 1}\left(\varphi_{i, j+1}-\varphi_{i, j}\right)-\varepsilon_{\mathrm{r} 2}\left(\varphi_{i, j}-\varphi_{i, j-1}\right)\right] .
\end{gathered}
$$

Dielektrinę skvarbą dielektrikų riboje pažymèję $\varepsilon_{\mathrm{r} 3}$, analogiškai užrašome normalès kitimo greičio $x$ ašies kryptimi išraišką:

$$
\frac{\partial D_{x}}{\partial x}=-\frac{\varepsilon_{0} \varepsilon_{\mathrm{r} 3}}{\Delta^{2}}\left(\varphi_{i+1, j}+\varphi_{i-1, j}-2 \varphi_{i, j}\right) .
$$

İašę (A1.19) ir (A1.18) i (A1.17), galime rasti taško potencialą dielektrikų riboje:

$$
\varphi_{i, j}=\frac{\varepsilon_{\mathrm{r} 1} \varphi_{i, j+1}+\varepsilon_{\mathrm{r} 2} \varphi_{i, j-1}+\varepsilon_{\mathrm{r} 3}\left(\varphi_{i+1, j}+\varphi_{i-1, j}\right)}{\varepsilon_{\mathrm{r} 1}+\varepsilon_{\mathrm{r} 2}+2 \varepsilon_{\mathrm{r} 3}} .
$$

Atliekant skaičiavimus, lygtis (P1.20) taikoma tik skirtingų dielektrikų riboje. Santykinè dielektrinè skvarba $\varepsilon_{\mathrm{r} 3}$ randame iš sąlygos, kad potencialai $\varphi_{i-1, j}$ ir $\varphi_{i+1, j}$ turi vienodą ịtaką $\varphi_{i, j}$ reikšmei:

$$
\varepsilon_{\mathrm{r} 1} \varphi_{i, j+1}+\varepsilon_{\mathrm{r} 2} \varphi_{i, j-1}=\varepsilon_{\mathrm{r} 3}\left(\varphi_{i-1, j}+\varphi_{i+1, j}\right) .
$$

Tada

$$
\varepsilon_{\mathrm{r} 3}=\frac{\varepsilon_{\mathrm{r} 1} \varphi_{i, j+1}+\varepsilon_{\mathrm{r} 2} \varphi_{i, j-1}}{\varphi_{i-1, j}+\varphi_{i+1, j}}
$$

Atliekant skaičiavimus, pirmiausia apskaičiuojama santykinė dielektrinè skvarba $\varepsilon_{\mathrm{r} 3}$, po to pagal (A1.20) skaičiuojamas potencialas skirtingų dielektrikų riboje.

Verta pastebėti, kad tuo atveju, kai aplinkinių mazgų potencialai nežymiai skiriasi, pagal (A1.22) $\varepsilon_{\mathrm{r} 3} \cong\left(\varepsilon_{\mathrm{r} 1}+\varepsilon_{\mathrm{r} 2}\right) / 2$.

Apskaičiavus potencialus analizuojamoje srityje atliekamas mikrojuostelių ilginių talpų apskaičiavimas. Šiam tikslui pasiekti sudaromas menamas kontūras $l_{\mathrm{C}}$ apie kiekvieną mikrojuostelę (A1.1 pav. a) ir apskaičiuojamas kiekvieno laidininko krūvis:

$$
Q=\oint_{S} \varepsilon \vec{E} d \vec{S}
$$


skaitmeniškai integruojant (A1.23) išraiškos integralą išilgai A1.1 pav., $a$ parodyto uždaro kontūro $l_{\mathrm{C}}$, aprèpiančio $i$-ajji daugialaidès linijos mikrojuostelę

$$
\rho_{i}=\frac{Q_{i}}{l}=\oint_{l_{\mathrm{C}}} \varepsilon \vec{E} \frac{\overrightarrow{d S}}{l}=\oint_{l_{\mathrm{C}}} \varepsilon(-\nabla \varphi) \cdot \overrightarrow{d n},
$$

čia $\overrightarrow{d n}=\frac{\overrightarrow{d S}}{l}, l-$ nagrinèjamos juostelès atkarpos ilgis.

Nagrinèjamu atveju potencialo pokytis normalès kryptimi išilgai integravimo kelio ieškomas kaip potencialų, dviejuose gretimuose per $\Delta n=1 \mathfrak{i}$ abi puses nuo integravimo kontūro nutolusiuose tinklelio taškuose, skirtumas. Taigi (A1.24) formulèje esantis potencialo gradientas $\nabla \varphi$ išreiškiamas taip:

$$
\nabla \varphi=\frac{\partial \varphi}{\partial n} \vec{n} \approx \frac{\Delta \varphi}{2 \Delta n} \approx \frac{\Delta \varphi}{2} .
$$

Taigi, (A1.25) išraišką ịrašę i (A1.24) lygtị ir pakeitę integravimo operaciją sumavimu, gauname formulę

$$
\rho_{i}=\sum_{l_{\mathrm{C}}} \varepsilon \frac{\Delta \varphi}{2} .
$$

Išskleista išraiška krūviui apskaičiuoti atrodytu taip:

$$
q=-\left(\begin{array}{c}
\ldots+\varepsilon_{1} \frac{\varphi_{i-2, j-1}-\varphi_{i-2, j+1}}{2}+\varepsilon_{1} \frac{\varphi_{i-1, j-1}-\varphi_{i-1, j+1}}{2} \\
+\frac{\varepsilon_{1}+\varepsilon_{2}}{2} \frac{\varphi_{i, j-1}-\varphi_{i, j-1}}{2}+\varepsilon_{2} \frac{\varphi_{i+1, j-1}-\varphi_{i+1, j+1}}{2}+\ldots
\end{array}\right),
$$

Ilginė talpa turint apskaičiuotą krūvị gaunama pagal išraišką:

$$
C_{i 1,0}=\frac{q_{i}}{\varphi_{i}}
$$

čia $i$ nurodo mikrojuostelès numerị, o 1 ir 0 apibūdina atitinkamai, kad dielektrinis pagrindas yra, arba jis pakeičiamas oru, $\varphi_{i}-i$-ajai mikrojuostelei analizès metu suteiktas potencialas. 
Apskaičiavus talpas galima apskaičiuoti DML charakteringaji impedansą $Z_{0 i}$, efektinę dielektrinę skvarbą $\varepsilon_{\text {ref } i}$ ir fazinị bangos greitị $v_{\mathrm{f} i}$ kiekvienai $i$ mikrojuostelei:

$$
\begin{gathered}
Z_{0 i}=\frac{1}{c_{0} \sqrt{C_{i 0} \cdot C_{i 1}}}, \\
\varepsilon_{\mathrm{ref} i}=\sqrt{\frac{C_{i 1}}{C_{i 0}}}, \\
v_{\mathrm{f} i}=\frac{c_{0}}{\sqrt{\varepsilon_{\mathrm{ref} i}}} .
\end{gathered}
$$




\section{B priedas. Momentų metodu grịstas daugialaidès mikrojuostelinès linijos matematinis modelis}

Specifinis daugialaidès linijos nevienalyteje terpeje atvejis $-N$ juosteliu daugialaidè mikrojuostelinė linija (DML), kurios apibendrinta sandara pateikta 2.1 pav. Terpès nevienalytiškumas tokioje linijoje, kaip ir kitose mikrojuostelinèse struktūrose, susidaro dèl dielektrinio pagrindo ir oro erdvès virš laidininkų sąsajos. Šiam nevienalytiškumui apibūdinti naudojamas atspindžio koeficientas (Štaras et. al., 2010)

$$
K=-\frac{\varepsilon_{\mathrm{r} 1}-\varepsilon_{\mathrm{r} 2}}{\varepsilon_{\mathrm{r} 1}+\varepsilon_{\mathrm{r} 2}}
$$

čia $\varepsilon_{\mathrm{r} 1}$ - DML pagrindo santykinè dielektrinè skvarba; $\varepsilon_{\mathrm{r} 2}-$ terpès virš dielektrinio pagrindo santykinè skvarba.

Sudarydami DML modelį, grịstą momentų metodu (Harrington, 1993), linijos signalines mikrojuosteles ịsivaizduosime be galo plonas, esančias erdvès dalyje virš dielektrinio pagrindo ir padalintas ị $\Delta W$ pločio $M=\sum_{n=1}^{N} M_{n}$ dalinių sričių, čia $M$ - mikrojuostelių daugialaidejje linijoje skaičius. Kiekvienos dalinès srities krūvio tankis $\rho_{\mathrm{s} i}$ nežinomas. Patogumo dèlei daroma prielaida, kad $i$ ojoje dalinèje srityje krūvio pasiskirstymo tankis $\rho_{\mathrm{si}}$ yra pastovus. Siekiant supaprastinti skaičiavimus taip pat tariama, kad kiekvienoje tokioje srityje krūvis sukoncentruotas be galo plonoje stygoje, esančioje srities centre (B1.1 pav.), taigi $i$-osios srities ilginis krūvis šiuo atveju apskaičiuojamas pagal formulę

$$
q_{i}=\rho_{\mathrm{s} i} \cdot \Delta W .
$$

İžemintos modelio ekrano plokštumos ekvipotencialinis paviršius gaunamas sudarant kiekvieno taškinio krūvio veidrodinị atspindị $-q_{i}$. B1.1 pav. matome, kad dèl nulinio laidininko storio krūviai DML modelyje yra prie pat dielektriko paviršiaus. Taško $P_{j}$ potencialas, kurị sužadina tame pačiame taške esantis krūvis, apskaičiuojamas kaip nuosavas potencialas sudejus krūvị $q_{j}$ ir jo pirmajji dalinị atvaizdą $K q_{j}$, t. y. $q_{j}+K q_{j}=(1+K) q_{j}$. 


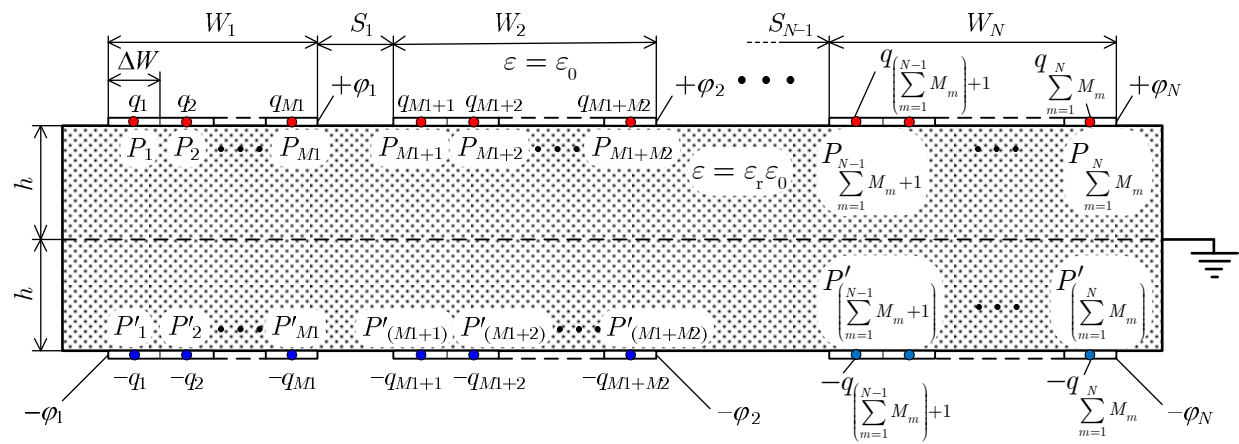

B1.1 pav. Daugialaidès mikrojuostelinès linijos juostelès, padalintos ị dalines sritis

Nagrinėjamomis išlygomis DML matematini modeli sudarys tiesinių lygčių sistema, apibūdinanti potencialų taškuose $P_{j}$ priklausomybę nuo krūvio tankių $\rho_{i}$, esančių visose dalinèse srityse.

Taikant dalinių atvaizdų principą (Silvester, Ferrari, 1996), kiekvieno krūvio įtaka potencialui nagrinejjamame linijos taške apskaičiuojama per 6 žingsnius:

1. Apskaičiuojama potencialo dalis, kurią sužadina tame pačiame taške esantis krūvis $q_{j}$ ir jo pirmasis dalinis atvaizdas $K q_{j}$ :

$$
\varphi_{1}\left(P_{j}: P_{j}\right)=-\frac{(1+K) q_{j}}{2 \pi \varepsilon_{0}}\left[\ln \left(\frac{\Delta W}{2}\right)-1\right],
$$

čia $\Delta W$ - dalinès srities plotis (B1.1 pav.), $K$ - atspindžio koeficientas, apskaičiuojamas pagal (B1.1) išraišką.

2. Nustatoma potencialo dalis, kurią sužadina kiti krūvio $q_{j}$ daliniai atvaizdai:

$$
\varphi_{2}\left(P_{j}: P_{j}\right)=\frac{K\left(1-K^{2}\right) q_{j}}{2 \pi \varepsilon_{0}} \sum_{n=1}^{\infty} K^{2(n-1)} \ln (4 n h) .
$$


3. Randama potencialo dalis, kurią sužadina taške $P_{j}^{\prime}$ esantis neigiamasis krūvis $-q_{j}$ ir visi jo daliniai atvaizdai:

$$
\varphi_{3}\left(P_{j}: P_{j}^{\prime}\right)=-\frac{\left(1-K^{2}\right) q_{i}}{2 \pi \varepsilon_{0}} \ln R\left(P_{j}: P_{i}\right) .
$$

4. Apibūdinamas sąryšis tarp potencialo taške $P_{j}$ dalies ir ją žadinančių krūvių $q_{i}$, esančių taškuose $P_{i}\left(1 \leq i \leq M\right.$ ir $i \neq j$, čia $M=\sum_{n=1}^{N} M_{n}-$ nežinomų krūvių visų mikrojuostelių dalinėse srityse skaičius) ir šių krūvių pirmụjų dalinių atvaizdų:

$$
\varphi_{4}\left(P_{j}: P_{i}\right)=-\frac{\left(1-K^{2}\right) q_{i}}{2 \pi \varepsilon_{0}} \ln R\left(P_{j}: P_{i}\right),
$$

čia $R\left(P_{j}: P_{i}\right)$ - atstumas tarp nagrinëjamo taško $P_{j}$ ir krūvio $q_{i}$.

5. Nustatoma potencialo, esančio taške $P_{j}$ dalis, kurią žadina kiti krūvių $q_{i}$ daliniai atvaizdai:

$$
\begin{gathered}
\varphi_{5}\left(P_{j}: P_{i}\right)=\frac{K\left(1-K^{2}\right) q_{i}}{4 \pi \varepsilon_{0}} . \\
\cdot \sum_{n=1}^{\infty} K^{2(n-1)} \ln \left[R^{2}\left(P_{j}: P_{i}\right)+(4 n h)^{2}\right] .
\end{gathered}
$$

6. Nustatomas sąryšis tarp potencialo taške $P_{j}$ dalies ir ją žadinančių veidrodinių krūvių $-q_{i}$ bei visų jų dalinių atvaizdų:

$$
\begin{gathered}
\varphi_{6}\left(P_{j}: P_{j}^{\prime}\right)=\frac{\left(1-K^{2}\right) q_{j}}{4 \pi \varepsilon_{0}} . \\
\cdot \sum_{n=1}^{\infty} K^{2(n-1)} \ln \left\{R^{2}\left(P_{j}: P_{i}^{\prime}\right)+[(2 n-1) 2 h]^{2}\right\} .
\end{gathered}
$$


Šitaip radus visas taško $P_{j}$ potencialo komponentes, sudaroma ši tašką atitinkanti Gryno funkcija (Silvester, Ferrari, 1996). Nagrinejjamuoju atveju ji gaunama pagal (B1.3)-(B1.8) išraiškas sudèjus gautas potencialų dalis

$$
\mathrm{G}_{i j}=\sum_{k=1}^{6} \varphi_{k}\left(P_{j}: P_{i}\right)
$$

Padarius prielaidą, kad ị visas mikrojuosteles siunčiama plius $1 \mathrm{~V}$ ịtampa, sudaroma tiesinių lygčių sistema, apibūdinanti vienetinius potencialus taškuose $P_{1} \ldots P_{M}$ :

$$
\left\{\begin{array}{cccc}
1= & \mathrm{G}_{11} q_{1}+\mathrm{G}_{12} q_{2}+ & \ldots & +\mathrm{G}_{1 M} q_{M} \\
1= & \mathrm{G}_{21} q_{1}+\mathrm{G}_{22} q_{2}+ & \ldots & +\mathrm{G}_{2 M} q_{M} \\
\ldots & \ldots & \ldots & \ldots \\
1= & \mathrm{G}_{M 1} q_{1}+\mathrm{G}_{M 2} q_{2}+ & \ldots & +\mathrm{G}_{M M} q_{M}
\end{array}\right.
$$

čia $\mathrm{G}_{i j}$ - koeficientai, atitinkantys Gryno funkciją, kuri apibūdina krūvio $q_{j}$ sužadinamą potencialą taške $P_{i}$.

(B1.10) perrašyta matricų pavidalu atrodo taip:

$$
\mathbf{1}=\mathbf{G} \times \boldsymbol{q} .
$$

Nežinomų krūvių $\boldsymbol{q}$ matrica apskaičiuojama atliekant matricų algebros veiksmus, pvz.:

$$
\boldsymbol{q}=\mathbf{G}^{-1} \times \mathbf{1},
$$

čia $\mathbf{G}^{-1}$ - atvirkštinè matrica.

Mikrojuostelių ilginès talpos šiuo atveju gaunamos tiesiog sudejjus visų $n$ osios mikrojuostelès $M_{n}$ dalinių sričių krūvius:

$$
C_{1 n}=\sum_{i=1}^{M_{n}} q_{i n} .
$$

Charakteringajji impedansą galima apskaičiuoti taikant išraišką 


$$
Z_{\mathrm{C} n}=\frac{1}{\mathrm{c}_{0} \sqrt{C_{1 n} C_{01 n}}},
$$

čia $\mathrm{c}_{0}-$ šviesos greitis vakuume, $C_{01 n}-n$-osios mikrojuostelès ilginè talpa, kai joje dielektrinis pagrindas yra oras. 
Raimondas POMARNACKI

ELEKTRODINAMINIŲ LĖTINIMO ITAISŲ TYRIMAS TAIKANT LYGIAGREČIĄSIAS KOMPIUTERINES SISTEMAS

Daktaro disertacija

Technologijos mokslai,

elektros ir elektronikos inžinerija (01T)

INVESTIGATION OF THE ELECTRODYNAMIC RETARD DEVICES USING

PARALLEL COMPUTER SYSTEMS

Doctoral Dissertation

Technological Sciences,

Electrical and Electronic Engineering (01T)

201111 14. 12,5 sp. I. Tiražas 20 egz.

Vilniaus Gedimino technikos universiteto

leidykla „Technika“,

Saulètekio al. 11, 10223 Vilnius,

http://leidykla.vgtu.lt

Spausdino UAB "Ciklonas“

J. Jasinskio g. 15, 01111 Vilnius 